\title{
MODELO INSUMO-PRODUTO COMO INSTRUMENTO DE AVALIAÇÃO ECONÔMICA DA CADEIA DE SUPRIMENTOS: O CASO DA EXPORTAÇÃO DE FLORES DE CORTE
}

\author{
Lilian Cristina Anefalos
}

Tese apresentada à Escola Superior de Agricultura

"Luiz de Queiroz", Universidade de São Paulo, para obtenção do título de Doutor em Ciências, Área de Concentração: Economia Aplicada.

P I R A C I C A B A

Estado de São Paulo - Brasil

Julho -2004 


\title{
MODELO INSUMO-PRODUTO COMO INSTRUMENTO DE AVALIAÇÃO ECONÔMICA DA CADEIA DE SUPRIMENTOS: O CASO DA EXPORTAÇÃO DE FLORES DE CORTE
}

\author{
Lilian Cristina Anefalos \\ Engenheiro Agrônomo
}

Orientador: Prof. Dr. JOSÉ VICENTE CAIXETA FILHO

\author{
Tese apresentada à Escola Superior de Agricultura \\ "Luiz de Queiroz", Universidade de São Paulo, \\ para obtenção do título de Doutor em Ciências, \\ Área de Concentração: Economia Aplicada.
}

P I R A C I C A B A

Estado de São Paulo - Brasil

Julho -2004 
Dados Internacionais de Catalogação na Publicação (CIP) DIVISÃO DE BIBLIOTECA E DOCUMENTAÇÃO - ESALQ/USP

\section{Anefalos, Lilian Cristina}

Modelo insumo-produto como instrumento de avaliação econômica da cadeia de suprimentos: o caso da exportação de flores de corte / Lilian Cristina Anefalos. -Piracicaba, 2004.

210 .

Tese (doutorado) - - Escola Superior de Agricultura Luiz de Queiroz, 2004.

Bibliografia.

1. Distribuição de mercadorias 2. Exportação 3. Flor de corte - Análise econômica 4. Insumo-produto - Modelos 5. Logística 6. Transporte multimodal I. Título

CDD 338.175966 
Aos meus pais Homero e Laila Ao meu querido Aryeverton À minha filha Yasmin 


\section{AGRADECIMENTOS}

Ao Prof. Dr. José Vicente Caixeta Filho, pelo seu total apoio, atenção e incentivo em cada uma das etapas deste trabalho. Sua orientação foi fundamental para o desenvolvimento e conclusão desta pesquisa.

Ao Prof. Joaquim José M. Guilhoto, que contribuiu desde o início para o aprimoramento teórico deste trabalho.

À Pesquisadora Científica Taís Tostes Graziano, ao Prof. Dr. José Matheus Perosa e ao Prof. Dr. Roberval Ribeiro, por terem auxiliado no aprofundamento desta pesquisa e melhor entendimento do setor de flores e plantas ornamentais.

Aos Pesquisadores Científicos José Roberto Vicente e Mario Antonio Margarido, por suas valiosas sugestões e pelo apoio em fases decisivas desta tese.

Aos Pesquisadores Científicos Ana Maria M. P. Camargo, Denise Viani Caser, Maria Carlota M. Vicente e Mário Pires de A. Olivette, por terem compartilhado sua experiência profissional e pela sua atenção no decorrer destes anos, sempre dispostos a me auxiliar nos mais diversos momentos.

Ao meu grande companheiro Aryeverton (“Ary”), pelo seu apoio e compreensão em todos os momentos desta importante etapa de nossas vidas. 
A todos os agentes que participam dos processos de exportação da cadeia de flores, que se dispuseram a me auxiliar no esclarecimento de informações relativas ao objeto deste estudo. A sua colaboração foi essencial para a condução e finalização desta pesquisa.

Aos professores e funcionários do Departamento de Administração, Economia e Sociologia Rural. Em especial à Maria Maielli Travalini e à Ligiana Clemente do Carmo, por sua atenção e ajuda ao longo destes anos.

À ESALQ, ao CNPQ e ao IEA, pelo apoio institucional e financeiro em todas as etapas deste estudo.

A todas as pessoas que, de alguma forma, contribuíram para o desenvolvimento deste trabalho.

Enfim, a todos os familiares e amigos, pelo carinho e incentivo em todas as fases desta jornada. 


\section{SUMÁRIO}

Página

LISTA DE FIGURAS ......................................................................... viii

LISTA DE QUADROS .........................................................................

LISTA DE TABELAS ..........................................................................

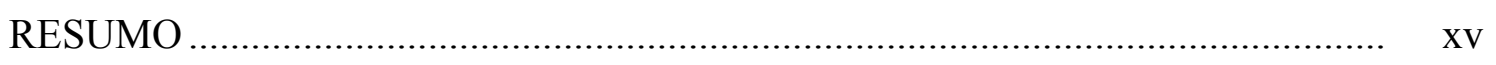

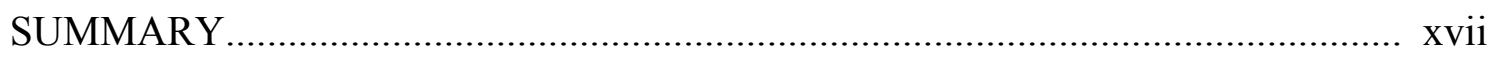

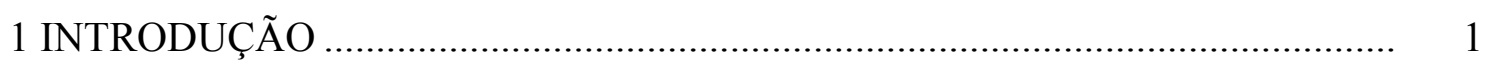

1.1 Descrição do problema e justificativa de sua importância.................................. 2

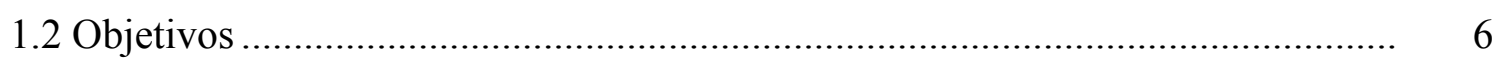

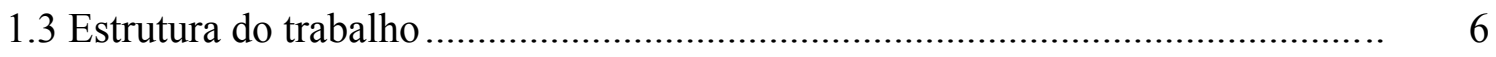

2 ASPECTOS ECONÔMICOS E LOGÍSTICOS DA EXPORTAÇÃO DE FLORES DE CORTE.......................................................................... 7

2.1 Panorama das exportações da floricultura brasileira........................................ 11

2.2 Logística e cadeia de suprimentos: aspectos gerais ....................................... 23

3 MATERIAL E MÉTODOS ..................................................................... 33

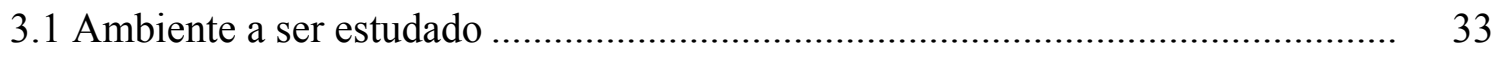

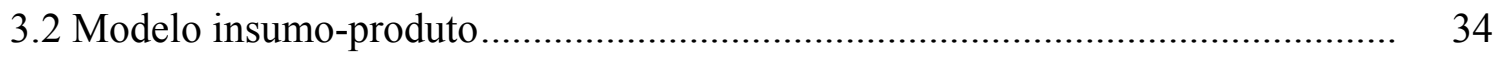

3.2.1 Modelo insumo-produto de processo ........................................................ 37

3.2.2 Modelo proposto para exportação de flores de corte ...................................... 44

3.2.3 Estrutura matemática do modelo............................................................ 47

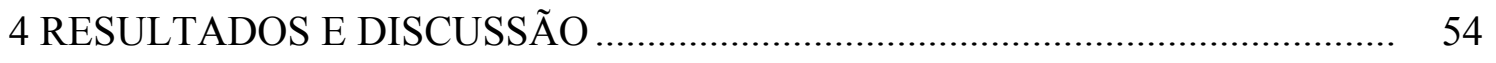

4.1 Processos da cadeia de flores de corte para exportação .................................... 56 


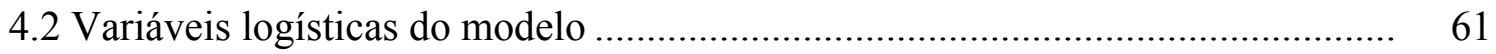

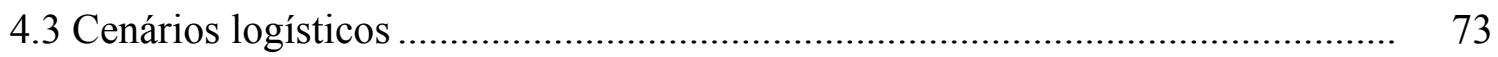

4.3.1 Cenário 1: déficit logístico em todos os processos da cadeia .......................... 79

4.3.2 Cenário 2: déficit logístico na cadeia, com maiores cuidados no processo de produção ........................................................................................... 90

4.3.3 Cenário 3: superávit logístico em todos os processos da cadeia...................... 98

4.3.4 Cenário 4: déficit logístico na cadeia, com falhas no processo de distribuição interna via modal rodoviário................................................................ 110

4.3.5 Cenário 5: déficit logístico na cadeia, com falhas no processo de distribuição externa via modal aéreo ............................................................................... 121

4.3.6 Análise geral dos cenários logísticos ..................................................... 132

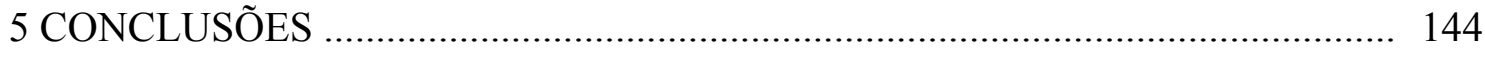

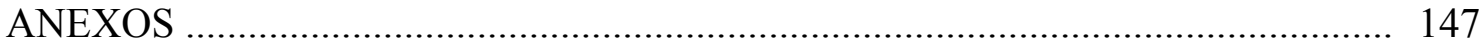

REFERÊNCIAS BIBLIOGRÁFICAS ............................................................ 191

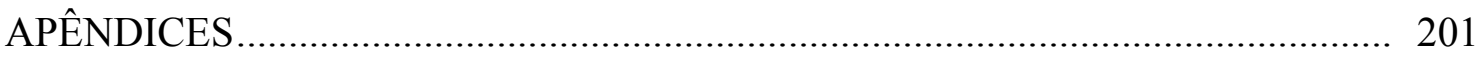




\section{LISTA DE FIGURAS}

Página

1 Porcentagem das importações (a) e da produção doméstica (b) de flores e plantas ornamentais nos EUA em relação ao consumo doméstico, 1989 a 2001 ... 4

2 Porcentagem das exportações para a Europa em relação ao total exportado para os mercados norte-americano e europeu ............................................................ 8

3 Cadeias de exportação de flores Brasil-EUA (A) e Brasil-Holanda (B), a partir de informações fornecidas por especialistas do setor.............................................. 12

4 Taxonomia dos modelos da cadeia de suprimentos ............................................ 37

5 Modelo insumo-produto de processo ................................................................. 38

6 Representação esquemática dos modelos propostos ............................................... 43

7 Estrutura geral do modelo insumo-produto de processo proposto para a exportação de flores de corte............................................................................. 45

8 Características da demanda de flores de corte destinadas à exportação.................. 55

9 Taxas de câmbio nominais, reais por dólar americano e euro, de janeiro/1999 a

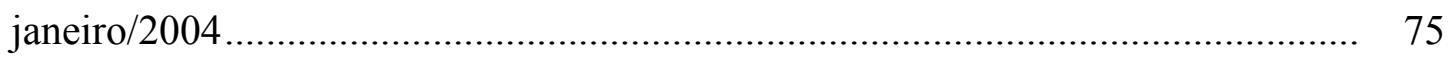

10 Fluxo das informações no modelo insumo-produto de processo ............................ 78

11 Custos, receitas e lucros totais para a cadeia de lírio nas 36 simulações do Cenário 1

12 Comparação dos lucros unitários de cada um dos processos para as produções bruta (a) e final (b) da flor lírio nas 36 simulações do Cenário 1 
13 Custos, receitas e lucros totais para a cadeia de gérbera 1 nas 36 simulações do Cenário 1

14 Comparação dos lucros unitários de cada um dos processos para as produções bruta (a) e final (b) de gérbera 1 nas 36 simulações do Cenário 1

15 Custos, receitas e lucros totais para a cadeia de gérbera 2 nas 36 simulações do Cenário 1

16 Comparação dos lucros unitários de cada um dos processos para as produções bruta (a) e final (b) da flor gérbera 2 nas 36 simulações do Cenário 1

17 Custos, receitas e lucros totais para a cadeia de lírio nas 36 simulações do Cenário 2

18 Comparação dos lucros unitários de cada um dos processos para as produções bruta (a) e final (b) da flor lírio nas 36 simulações do Cenário 2 .

19 Custos, receitas e lucros totais para a cadeia de gérbera 1 nas 36 simulações do Cenário 2

20 Comparação dos lucros unitários de cada um dos processos para as produções bruta (a) e final (b) da flor gérbera 1 nas 36 simulações do Cenário 2

21 Custos, receitas e lucros totais para a cadeia de gérbera 2 nas 36 simulações do Cenário 2

22 Comparação dos lucros unitários de cada um dos processos para as produções bruta (a) e final (b) da flor gérbera 2 nas 36 simulações do Cenário 2

23 Custos, receitas e lucros totais para a cadeia de lírio nas 36 simulações do Cenário 3

24 Comparação dos lucros unitários de cada um dos processos para as produções bruta (a) e final (b) da flor lírio nas 36 simulações do Cenário 3.

25 Custos, receitas e lucros totais para a cadeia de gérbera 1 nas 36 simulações do Cenário 3

26 Comparação dos lucros unitários de cada um dos processos para as produções bruta (a) e final (b) da flor gérbera 1 nas 36 simulações do Cenário 3

27 Custos, receitas e lucros totais para a cadeia de gérbera 2 nas 36 simulações do Cenário 3 
28 Comparação dos lucros unitários de cada um dos processos para as produções bruta (a) e final (b) da flor gérbera 2 nas 36 simulações do Cenário 3

29 Custos, receitas e lucros totais para a cadeia de lírio nas 36 simulações do Cenário 4

30 Comparação dos lucros unitários de cada um dos processos para as produções bruta (a) e final (b) da flor lírio nas 36 simulações do Cenário 4

31 Custos, receitas e lucros totais para a cadeia de gérbera 1 nas 36 simulações do Cenário 4

32 Comparação dos lucros unitários de cada um dos processos para as produções bruta (a) e final (b) da flor gérbera 1 nas 36 simulações do Cenário 4

33 Custos, receitas e lucros totais para a cadeia de gérbera 2 nas 36 simulações do Cenário 4

34 Comparação dos lucros unitários de cada um dos processos para as produções bruta (a) e final (b) da flor gérbera 2 nas 36 simulações do Cenário 4

35 Custos, receitas e lucros totais para a cadeia de lírio nas 36 simulações do Cenário 5

36 Comparação dos lucros unitários de cada um dos processos para as produções bruta (a) e final (b) da flor lírio nas 36 simulações do Cenário 5

37 Custos, receitas e lucros totais para a cadeia de gérbera 1 nas 36 simulações do Cenário 5

38 Comparação dos lucros unitários de cada um dos processos para as produções bruta (a) e final (b) da flor gérbera 1 nas 36 simulações do Cenário 5

39 Custos, receitas e lucros totais para a cadeia de gérbera 2 nas 36 simulações do Cenário 5

40 Comparação dos lucros unitários de cada um dos processos para as produções bruta (a) e final (b) da flor gérbera 2 nas 36 simulações do Cenário 5

41 Porcentagem do custo logístico em relação ao custo total para as 36 simulações dos 5 cenários da flor lírio (a), gérbera 1 (b) e gérbera 2 (c).

42 Relação entre lucro e custo, considerando insumos e produtos logísticos de (a) lírio, (b) gérbera 1 e (c) gérbera 2 
43 Ciclo de crescimento de bulbos de flores de Amaryllis ...................................... 208

44 Variedades de lírio oriental (a) e asiático (b) ................................................... 209

45 Variedades de gérbera .............................................................................. 210 


\section{LISTA DE QUADROS}

Página

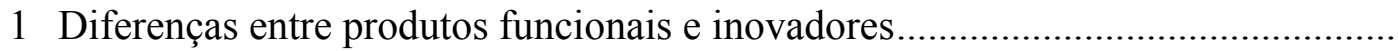

2 Componentes do modelo insumo-produto de processo para determinada empresa ou cadeias de suprimentos global e local............................................... 40

3 Componentes do modelo insumo-produto de processo para a cadeia de suprimentos de flores de corte......................................................................... 48

4 Identificação dos agentes pertencentes a cada um dos processos da cadeia ........... 57

5 Relação entre as variáveis logísticas no cálculo intermediário e no modelo .......... 62 


\section{LISTA DE TABELAS}

Página

1 Consumo per capita e taxas de crescimento de flores de corte de alguns países, 1990, 1994, 2000 e 2001

2 Comparação de custos operacionais e de investimento, em termos relativos, na produção de bulbos e de flores de corte

3 Estimativas do lead time total do ciclo logístico do transporte aéreo para exportação de flores de corte, em dias

4 Estimativas do lead time total do ciclo logístico do transporte aéreo, em dias, e variação percentual de superávit e déficit logísticos em relação ao ciclo ideal ......

5 Simulações efetuadas para a construção de cada um dos cenários, para cada um dos tipos de flores lírio e gérberas 1 e 2

6 Indicação das simulações com os maiores custos, receitas e lucros para cada um dos cenários $(\mathrm{R} \$)$

7 Indicação das simulações com os menores custos, receitas e lucros para cada um dos cenários $(\mathrm{R} \$)$.

8 Taxa média de crescimento do custo total (\%) considerando o rateio das despesas de exportação entre 1, 4, 10 e 20 produtores.

9 Principais resultados obtidos das simulações do primeiro cenário logístico para a cadeia como um todo

10 Principais resultados obtidos das simulações do segundo cenário logístico para a cadeia como um todo 
11 Principais resultados obtidos das simulações do terceiro cenário logístico para a cadeia como um todo................................................................................. 160

12 Principais resultados obtidos das simulações do quarto cenário logístico para a cadeia como um todo..

13 Principais resultados obtidos das simulações do quinto cenário logístico para a cadeia como um todo.

14 Principais resultados obtidos das simulações do primeiro cenário logístico para cada um dos processos

15 Principais resultados obtidos das simulações do segundo cenário logístico para cada um dos processos

16 Principais resultados obtidos das simulações do terceiro cenário logístico para cada um dos processos

17 Principais resultados obtidos das simulações do quarto cenário logístico para cada um dos processos

18 Principais resultados obtidos das simulações do quinto cenário logístico para cada um dos processos

19 Principais características de aeronaves utilizadas em aeroportos brasileiros 


\title{
MODELO INSUMO-PRODUTO COMO INSTRUMENTO DE AVALIAÇÃO ECONÔMICA DA CADEIA DE SUPRIMENTOS: O CASO DA EXPORTAÇÃO DE FLORES DE CORTE
}

\author{
Autora: LILIAN CRISTINA ANEFALOS \\ Orientador: Prof. Dr. JOSÉ VICENTE CAIXETA FILHO
}

\section{RESUMO}

O principal objetivo desta tese foi avaliar o desempenho das atividades do setor de flores de corte, com relação à integração da cadeia e à competitividade no mercado externo, assim como aprimorar o entendimento das contribuições e entraves da logística para a floricultura. Para tal foi desenvolvido um modelo insumo-produto que se revelou como ferramenta importante para avaliar os impactos de alterações nos processos que fazem parte dessa cadeia de exportação. Foi realizada coleta de dados junto a agentes representativos da cadeia de flores, localizados na região de Holambra e na Grande São Paulo, relacionados a cada uma das fases associadas aos processos de exportação de gérbera e lírio, ou seja, desde a produção (A), passando pela distribuição interna via modal rodoviário (B), distribuição externa via modal aéreo (C) e distribuição externa via modal rodoviário (D). Para caracterizar situações de déficit e superávit logísticos e avaliar os impactos de falhas em cada um dos processos da cadeia de flores de corte, foram construídos cinco cenários. $\mathrm{Na}$ sua composição foram identificados parâmetros técnicos, principalmente relacionados à logística, que pudessem interferir na exportação de flores de corte. Os valores de três deles - número de hastes por caixa, taxa de câmbio e frete aéreo - foram alterados e combinados, constituindo 36 simulações para auxiliar 
na análise desses cenários. Os resultados obtidos sinalizaram para a necessidade de ajustes logísticos diferenciados em cada um dos processos, variando em função do tipo de relacionamento estabelecido entre os agentes envolvidos nas diferentes etapas. $\mathrm{O}$ desempenho da cadeia como um todo pode ser afetado pela falta de conhecimento sobre as características do produto exportado, que gera distorções nas informações repassadas para os agentes da cadeia. Verificou-se que as falhas ocorridas em cada etapa podem aumentar significativamente os custos e inibir as exportações em situações mais desfavoráveis do câmbio. Por outro lado, o aumento no número de hastes comercializadas por caixa representou uma alternativa para amenizar o incremento de custos ao longo da cadeia. Apesar da produção caracterizar-se como elo importante entre todas as etapas, se não forem verificadas condições mínimas para armazenamento e transporte adequados, poderão ocorrer perdas significativas no volume comercializado, com redução da competitividade desse produto no exterior e não continuidade de sua exportação no longo prazo. Assim sendo, confirmou-se que a integração da cadeia é essencial para a otimização dos processos de exportação de flores, incluindo a maximização dos resultados econômicos e financeiros relacionados a esse segmento de negócios. 


\title{
INPUT-OUTPUT MODEL FOR ECONOMIC EVALUATION OF THE SUPPLY CHAIN: THE CASE OF CUT FLOWERS EXPORTATION
}

\author{
Author: LILIAN CRISTINA ANEFALOS \\ Adviser: Prof. Dr. JOSÉ VICENTE CAIXETA FILHO
}

\section{SUMMARY}

The main objectives of this thesis were to evaluate the performance of the cut flower sector, concerning supply chain integration and external market competitiveness, and to heighten the understanding of the contributions and obstacles of logistics to floriculture. An input-output model developed proved to be an important tool to evaluate the impact of changes in the processes involved in that exportation chain. Data were colleted from representative players of the flower chain, in the Holambra and Greater Sao Paulo regions, referring to every one of the stages associated to the gerbera and lily exportation processes, i.e., from production (A), to internal distribution by highway modal (B), to external distribution by airway modal (C) and to external distribution by highway modal (D). Five scenarios were built to analyze deficit and surplus situations and to evaluate the impact of failures occurring in each process of the cut flower chain. Technical parameters were identified in the scenarios composition, mainly related to logistics, that could interfere in the cut flower exportation. The values of three of them number of stems by box, exchange rate and air freight - were modified and combined to create 36 simulations to support the analysis of those scenarios. The results point to the need for differentiated logistic adjusts in each process, according to the type of relationship established among the players involved in the stages. The development of 
the chain as a whole may be affected by lack of knowledge on the characteristics of the exported product, which causes distortions in the information forwarded to the players. It was verified that the failures occurring in each phase could increase costs and inhibit exportations in the event of unfavorable exchange rate movements. On the other hand, an increased stem number commercialized by box represented an alternative to assuage cost increases through the chain. Although production is characterized as an important link throughout all stages, unless the minimum conditions for adequate storage and transport are fulfilled, there will be significant losses in the commercialized volume, thus reducing this product competitiveness abroad and discontinuing its exportation in the long run. Therefore, it was corroborated that the integration of the chain is essential to the optimization of flower exportation, including the maximization of the economic and financial results related to this business segment. 


\section{INTRODUÇÃO}

Este trabalho objetiva estudar os processos de gestão da cadeia de suprimentos no setor de flores no Brasil, em 2002 e 2003, com foco no ramo de exportações. Há claros avanços desse setor no sentido de se ajustar às tendências mundiais, procurando reduzir problemas inerentes ao fluxo de informação na cadeia e ao acesso facilitado às inovações tecnológicas relacionadas à produção e comercialização de flores temperadas, tropicais e folhagens. Há expectativas de que esse segmento possa alavancar a geração de empregos e renda junto a outros setores do agronegócio brasileiro.

Apesar de ainda não haver consolidação do consumo de flores no mercado interno, a existência de alternativas de mercado em outros países dá maior flexibilidade aos produtores, principalmente ao direcionar de forma adequada seus produtos e diferenciá-los por meio de nichos de mercado, controlando as condições de oferta interna de flores nas épocas de maior demanda pelo produto. A valorização do produto, no entanto, não depende apenas disso. Há diversos fatores envolvidos na sua qualidade, que vão desde adoção de processos de produção mais eficientes dentro da propriedade, aos cuidados no armazenamento e distribuição do produto de sua origem até o destino final, que podem afetar a sua durabilidade e a sua aparência, refletindo diretamente sobre seu preço final. Ao se considerar o mercado externo, verifica-se que as exigências do consumidor final são maiores e, portanto, há riscos mais elevados de não haver aceitabilidade do produto brasileiro se não forem seguidos os padrões internacionais de qualidade e cuidados pós-colheita.

Para que se tenha vantagem competitiva em relação a outros países, a preocupação com a eficiência logística deve ser muito maior, principalmente quando se trabalha com flores de corte, que possuem menor durabilidade ao se comparar com 
outros produtos não-perecíveis atualmente exportados pelo Brasil. Há, também, vários cuidados no seu manuseio, relacionados à colocação nas embalagens e o seu acondicionamento adequado em caminhões e aviões, com controle de temperatura dentro dos veículos que transportam o produto. Tanto a cadeia de flores temperadas quanto de tropicais exigem um monitoramento constante do produto ao longo de toda a cadeia para que o processo logístico seja otimizado em todas as etapas da exportação, garantindo a obtenção de preços mais competitivos no mercado externo. Isso também pode se refletir internamente, uma vez que a oferta de produtos diferenciados vendidos no mercado doméstico poderá suprir demandas de segmentos específicos e atingir preços melhores.

Nesse sentido, as seções apresentadas a seguir documentam a relevância e os objetivos a serem tratados neste estudo.

\subsection{Descrição do problema e justificativa de sua importância}

A produção de flores e plantas ornamentais no Brasil está concentrada no Estado de São Paulo. De acordo com Florabrasilis (2002), o faturamento mensal do varejo foi da ordem de R\$ 13,8 milhões, valor obtido a partir de levantamento realizado em 12 estados brasileiros, em 53 de suas principais cidades, entre abril e outubro de 2002. Nota-se que esse ramo tem desempenhado um papel relevante em termos de volume comercializado, e São Paulo destaca-se em relação aos demais estados com R 5,8 milhões de vendas mensalmente, correspondendo a $42,50 \%$ do valor total adquirido pelo varejo no Brasil.

De acordo com FNP Consultoria \& Comércio (2001), o Estado de São Paulo concentra cerca de $70 \%$ da produção nacional. Dentre os produtos comercializados pelo setor, em 1998 as flores de corte representaram aproximadamente 51\% do total das vendas, de acordo com estimativas do faturamento bruto do setor. Os demais segmentos - vaso, jardinagem, vaso verde e folhagem - tiveram participações menores em relação ao total de vendas nesse mesmo ano: $25 \%, 12 \%, 11 \%$ e $1 \%$, respectivamente. 
Para que eleve sua participação no mercado internacional o setor terá que enfrentar restrições, dentre as quais se destaca a adequação a padrões de qualidade e fitossanitários. Em relação ao mercado externo, Claro (1998) destaca que há espécies, tais como orquídeas, bromélias e flores de cerrado, que têm potencial para exportação, apesar de serem ainda pouco exploradas no Brasil. Conforme Brasil (2004), a exportação de flores e plantas foi de US\$ 13 milhões em 1999, US\$ 11.9 milhões em 2000 e US\$ 13.3 milhões em 2001. Dentre os produtos exportados e países destino, de acordo com Motos (2000a), pode-se relacionar:

a) mudas de crisântemos (Holanda; Itália; Inglaterra; Japão; Dinamarca; Noruega;

Argentina; Paraguai; Uruguai);

b) bulbos de gladíolos (Holanda; México; Chile; Uruguai);

c) bulbos de Amaryllis (Holanda; Estados Unidos; Argentina; México);

d) mudas de begônias (Holanda); bulbos de lírios (Holanda);

e) mudas de violetas (Holanda);

f) bulbos diversos (Holanda);

g) mudas de Calatheas (Holanda);

h) mudas de forrações diversas (diversos países da Europa).

Nos últimos anos tem havido busca por ampliação na inserção das flores de corte em vários países e por consolidação em mercados consumidores, como é o caso da Holanda e dos EUA. Há metas de expansão das exportações dos produtos do setor de flores para esses países, incluídas no programa Florabrasilis.

Em relação aos EUA, observa-se que as importações de flores e plantas ornamentais mantiveram-se constantes de 1989 a 2001 em relação ao seu consumo doméstico, com base em 36 maiores estados americanos, de acordo com Floriculture and Nursery Crops Situation and Outlook Yearbook (2002). Por outro lado, nesse período houve tendência de aumento nas importações de flores de corte para os EUA conforme mostra a Figura 1(a). As importações de flores de corte do Brasil ainda possuem participação marginal para os EUA. 


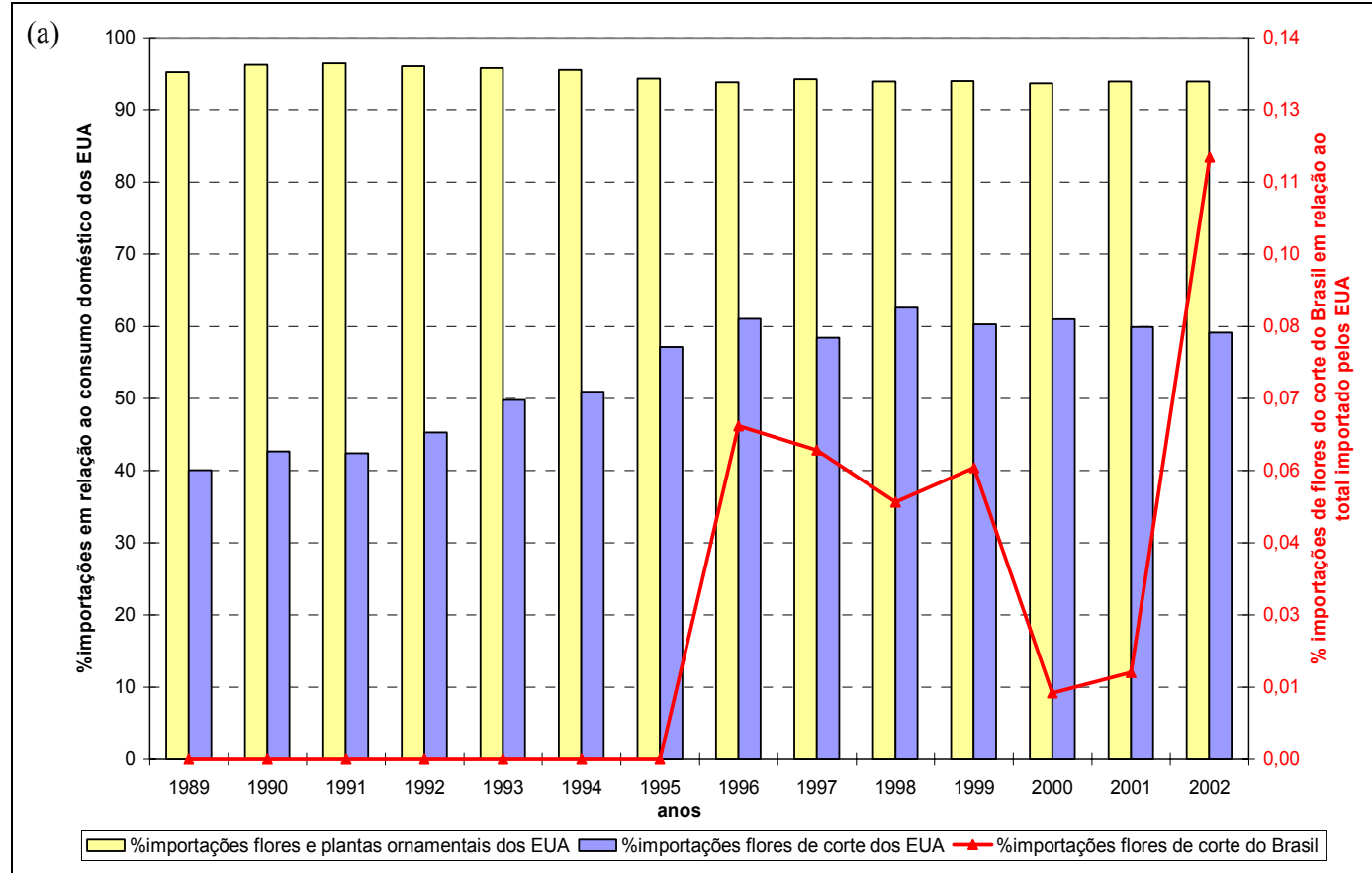

(b)

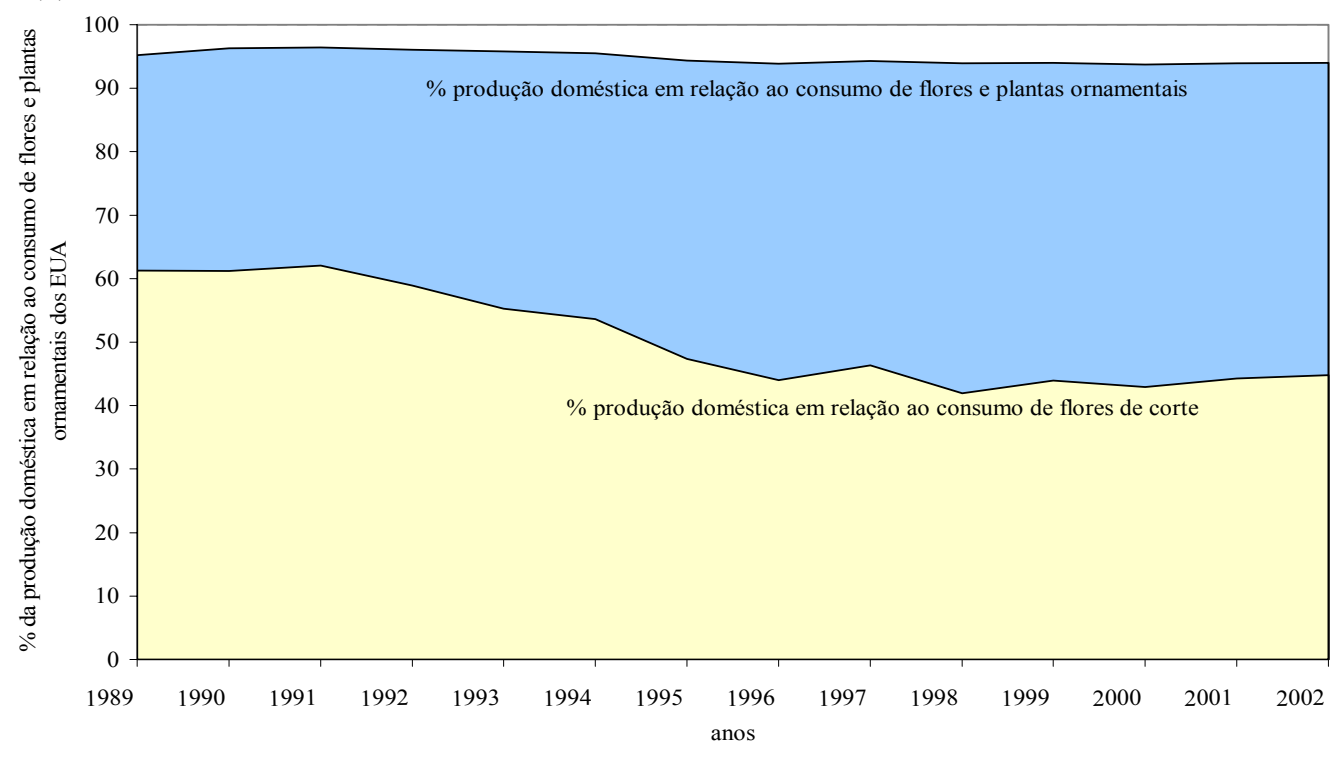

Figura 1 - Porcentagem das importações (a) e da produção doméstica (b) de flores e plantas ornamentais nos EUA em relação ao consumo doméstico, 1989 a 2001

Fonte: Floriculture and Nursery Crops Situation and Outlook Yearbook $(2002,2003)$ e Brasil (2004) 
Ao se analisar o quanto essas representam no montante total norte-americano, observa-se que houve recuperação crescente a partir de 2001, já elevando a participação das exportações brasileiras para esse país de $0,02 \%$ para $0,12 \%$ em 2002 , provavelmente derivada da implantação do programa Florabrasilis. A produção doméstica de flores de corte dos EUA obteve queda de aproximadamente $9 \%$ ao ano em relação ao consumo doméstico, tendo como referência o ano de 1989, o que pode observado na Figura 1(b). Esses fatores podem indicar que há perspectivas para a inserção de produtos importados (incluindo o brasileiro) nesse mercado, desde que se verifiquem os padrões de qualidade exigidos pelo consumidor norte-americano.

Dadas as características do mercado norte-americano, que tem direcionado suas importações de flores de corte para grandes distribuidores, há a possibilidade de se exportar produtos com qualidade e preço mais competitivos que para a Holanda, cujas vendas concentram-se nos leilões e há demandas de determinadas variedades de flores, não necessariamente cultivadas no Brasil.

Apesar de iniciativas pontuais de alguns produtores e empresas, o setor de flores ainda é inexpressivo em termos de participação na pauta de exportações brasileiras. Contudo, há expectativas de que ampliará sua participação no mercado externo com a implantação do Programa Brasileiro de Exportação de Flores e Plantas Ornamentais (Florabrasilis), criado em 2000.

Assim sendo, torna-se relevante a realização de trabalhos voltados para a compreensão do papel de todos os integrantes da cadeia de exportação de flores, e dos processos logísticos, que garantam que os produtos sejam entregues no destino final na quantidade exata, na hora determinada e pelo preço e qualidade acertados entre vendedor e comprador. A partir de então, poderiam surgir maiores vantagens competitivas em relação aos demais países concorrentes e, conseqüentemente, maior inserção em mercados consumidores internacionais, cujos preços pagos são mais elevados relativamente aos praticados no Brasil em função de diferencial de renda e fatores culturais. 


\subsection{Objetivos}

Para avaliar o desempenho das atividades do setor de flores de corte, com relação à integração da cadeia e à competitividade no mercado externo, e para entender quais as contribuições e entraves da logística para a floricultura, objetiva-se:

1. analisar a natureza da demanda das flores de corte, para prover um melhor entendimento dessa cadeia;

2. representar o setor de flores de corte para exportação por meio do modelo de insumo-produto de processo, para analisar principalmente os processos logísticos, que interferem significativamente no desempenho da cadeia de suprimento de flores de corte;

3. construir cenários específicos para analisar os processos logísticos e seus impactos junto aos principais agentes integrantes da cadeia de flores de corte, visando a definição de políticas para o setor. Inicialmente, procurar-se-á avaliar as exportações potenciais aos EUA e verificar a viabilidade de expandir o modelo para outros produtos e países.

\subsection{Estrutura do trabalho}

Esta tese está dividida em cinco capítulos: o primeiro, esta introdução; o segundo parte, que aborda aspectos gerais sobre as exportações brasileiras de flores e plantas ornamentais, com foco na logística e cadeia de suprimentos; o terceiro, que descreve o modelo insumo-produto de processos e apresenta o modelo proposto para a floricultura do Brasil, centrado nas exportações; o quarto apresenta e discute os resultados obtidos na pesquisa; no quinto capítulo estão descritas as conclusões do trabalho. 


\section{ASPECTOS ECONÔMICOS E LOGÍSTICOS DA EXPORTAÇÃO DE FLORES DE CORTE}

Neste capítulo pretende-se apresentar alguns aspectos relevantes do setor de flores e também relacionados à sua logística de exportação, relativos à realidade brasileira e de outros países representativos.

De acordo com Motos (2000b), além dos tradicionais países produtores de flores (Holanda, Itália, Dinamarca, Japão), a produção mundial está se expandindo para outros países, destacando-se dentre os principais exportadores na atualidade: Colômbia, Itália, Israel, Bélgica, Costa Rica, Canadá, EUA, Quênia e Alemanha, entre outros.

Segundo Góes (1997), no caso da Holanda, seu grande sucesso no mercado internacional deve-se principalmente ao sofisticado e eficiente sistema logístico de distribuição e comercialização, conseguindo disponibilizar rapidamente os pedidos dos seus clientes na Europa e nos outros continentes.

Os principais países exportadores da América Latina (Colômbia, Costa Rica e Equador) buscam consolidar seus produtos principalmente nos mercados europeu e norte-americano. De acordo com dados de 1997 a 2000, publicados por Pathfast (2001) e reproduzidos na Figura 2, observa-se que com relação aos bulbos, a Costa Rica concentra a maioria das exportações com destino ao mercado europeu. Em 2000 seu valor comercializado para a Europa foi da ordem de US\$ 25 milhões, contra US\$ 142 mil e US\$ 24 mil das exportações da Colômbia e do Equador, respectivamente. O valor exportado de flores de corte colombianas para os EUA cresceu 13\% em $2000 \mathrm{com}$ relação a 1997, representando $84 \%$ do seu valor total exportado nesse ano (por volta de US\$ 431 milhões), com relação ao total comercializado nos mercados americano e europeu. 


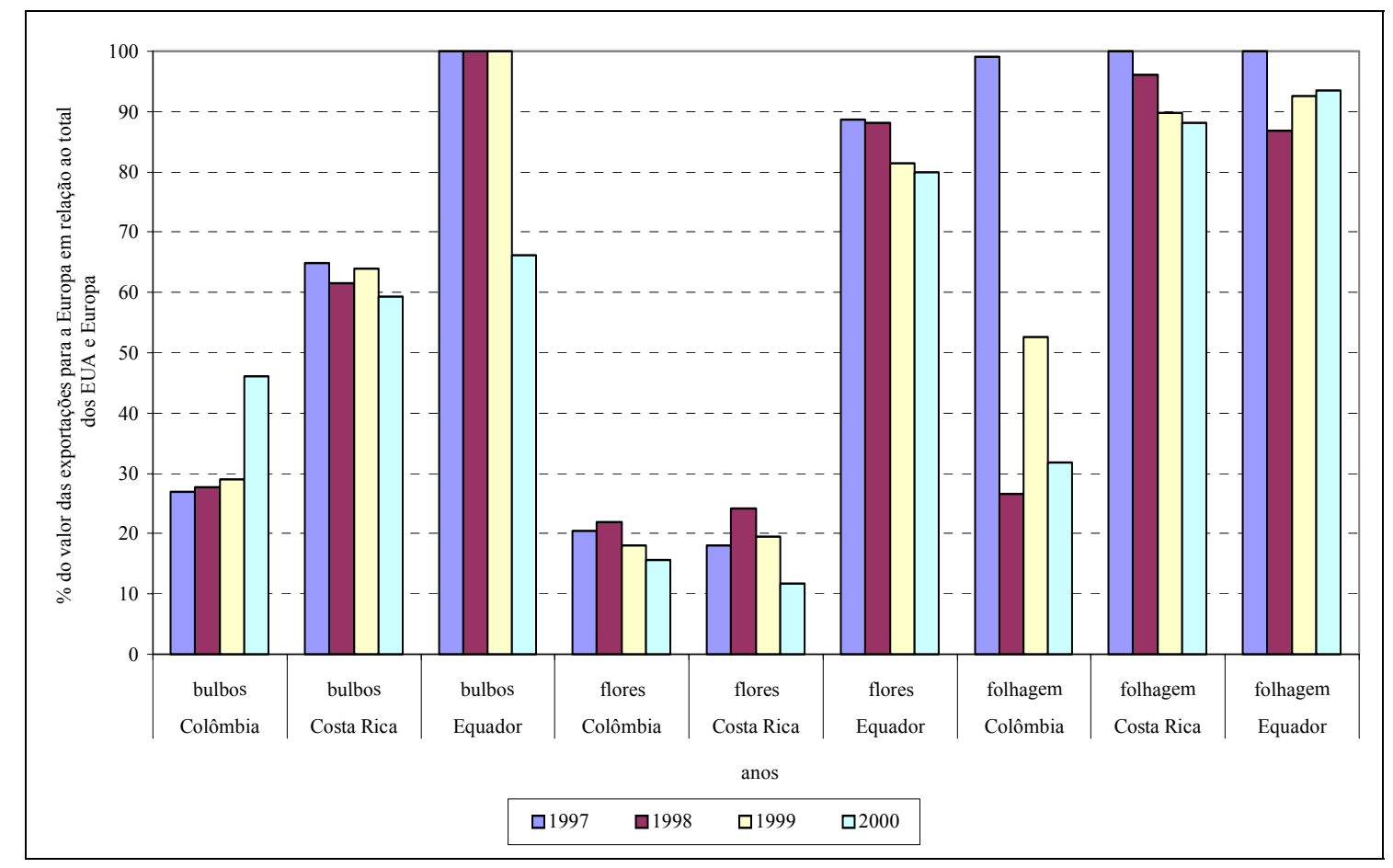

Figura 2 - Porcentagem das exportações para a Europa em relação ao total exportado para os mercados norte-americano e europeu

Fonte: adaptado de Pathfast (2001)

${ }^{1}$ Para os anos de 1999 e 2000 foram considerados os seguintes países para compor o mercado europeu: Alemanha, Áustria, Bélgica, Dinamarca, Espanha, Finlândia, França, Grécia, Holanda, Irlanda, Itália, Portugal, Reino Unido, Suiça, Suécia. Em 1998, não foi incluída a Irlanda e em 1997 foi excluída a Grécia, Finlândia, Irlanda, Portugal e Suíça, por não haver informações sobre esses países na referida base de dados

Apesar de o Equador ter redirecionado uma pequena parcela de suas exportações para os EUA, em 2000 ainda $80 \%$ do valor total de flores de corte era exportado para a Europa, totalizando US\$ 483 milhões. A Costa Rica destaca-se também pelas suas exportações de folhagens de corte para a Europa, quase duas vezes superior ao valor atingido com a venda de bulbos. Em relação aos outros dois países, Colômbia e Equador, esse produto também é muito pouco representativo ao compará-lo com o valor obtido da comercialização de flores de corte para a Europa. De 1997 a 2000 esses países tiveram tendência de queda nas exportações de bulbos, cujos valores já eram pouco 
significativos no início do período, em relação aos demais produtos destinados ao mercado europeu.

Como os consumidores europeus são exigentes quanto à origem e qualidade do produto que adquirem no mercado, países da América Latina tais como Colômbia, Costa Rica e Equador têm se preocupado em obter o certificado ambiental - selo verde relacionado ao correto manejo ambiental e trabalhista do setor de flores. No entanto, de acordo com Lucas (2001), tais iniciativas são ainda incipientes e não envolvem uma parte significativa dos produtores. No Brasil, em contraposição a essas medidas, o uso intensivo de defensivos químicos dificulta a obtenção do selo ambiental, uma vez que a sua utilização indiscriminada pode estar gerando problemas de saúde em funcionários das empresas, conforme relatado por Walt (2001).

De acordo com Demarchi (2001), o bom desempenho dos países andinos deve-se ao fato de usufruírem vantagens comerciais oferecidas pelos países europeus, principalmente em relação às tarifas de importação (praticamente nulas). Entre a Colômbia e os Estados Unidos há uma política similar, cujo objetivo central é combater a disseminação do plantio de coca através da diversificação das culturas. Conforme Floriculture and Nursery Crops Situation and Outlook Yearbook (2002), os Estados Unidos têm importado aproximadamente $60 \%$ das flores cortadas a partir de 2000 . Do total importado de rosas pelos Estados Unidos nesse ano, 61\% originaram-se da Colômbia, de acordo com Pathfast (2001).

Esse tratamento preferencial, conforme Walt (2001), não ocorre com o Brasil, que sofre sobretaxas que oscilam entre 1,60 e 11,20\%, em função do nível de abastecimento, para colocar seus produtos na Europa. Desta forma, para que o Brasil se torne mais competitivo no exterior, deve haver redução de custos, com investimentos crescentes em tecnologia e em diferenciação de produtos.

Conforme Walt (2001), a concorrência internacional está se acirrando, pois as empresas holandesas estão buscando melhorar a sua produtividade com o uso de tecnologias mais avançadas e a instalação de plantações em regiões mais propícias ao cultivo de flores, como é o caso do continente africano (Zimbábue e Quênia) e de Israel. De acordo com British Columbia (2003), alguns países da América Central e do Sul 
tiveram elevação de sua produção de flores, em função de seus custos de produção menores, relacionados às condições climáticas favoráveis e baixos salários, e também aos custos de transporte, como é o caso da Colômbia, que é o segundo maior exportador de flores de corte, depois da Holanda.

O bouquet é outro produto que está sendo valorizado nos Estados Unidos, cujo valor agregado é, em geral, mais elevado que as flores de corte sem esse arranjo e está sendo oferecido também no varejo, de acordo com Miller (2003).

Outro ponto fundamental refere-se à rastreabilidade das flores. De acordo com Machado (2000, p. 83) a rastreabilidade está "relacionada à capacidade de se identificar o produto, em termos locacionais, de seus atributos, por meio de um sistema de codificação impresso no mesmo”. Hughes (2000) nota que, em estudos conduzidos no Quênia, observou-se que os grandes produtores exportavam diretamente para Alemanha, Reino Unido e Holanda por meio de canais de fornecimento totalmente integrados, que garantiam rastreabilidade, controle de qualidade, espaço de cargas nos vôos e redução nos custos, devido ao envolvimento de um menor número de players na distribuição. Em contraposição, os pequenos produtores seriam intermediados por agentes, com meios de propaganda menos eficientes e com riscos mais elevados para o embarque de suas mercadorias nos vôos desejados.

No transporte internacional de flores de corte predominam aviões e caminhões e, por se tratar de um produto perecível, há diversos riscos envolvidos. Se houver qualquer atraso no transporte, como por exemplo, por engarrafamento no trânsito, superlotação ou recusa em embarcar flores em embalagens não adequadas (sem pallets), ou mesmo por falhas em utilizar operadores não especializados, podem ocorrer perdas para o exportador, que dificultam ainda mais a entrada do produto em países estrangeiros.

Conforme Barletta (1995), apesar de necessitarem de prioridade no manuseio e nos serviços aéreos, as flores possuem menor valor agregado quando comparadas a produtos eletrônicos ou componentes de máquinas. Porém, no Brasil, a constância na oferta de outros produtos é que se constitui num fator condicionante para que as empresas não dêem preferência ao transporte de flores. 
Por outro lado, o seu transporte mais eficiente depende da companhia aérea utilizada, da rota e do destino que as flores terão. No âmbito internacional, as empresas aéreas têm sofrido concorrência forte no decorrer dos anos de empresas especializadas no transporte noturno de flores, tais como Fedex e United Parcel Service, e de empresas importadoras de flores da América do Sul, que contribuem para minimizar problemas com o seu transporte.

\subsection{Panorama das exportações da floricultura brasileira}

$\mathrm{Na}$ exportação flores de corte várias cadeias podem ser analisadas, dependendo do país de destino. A Figura 3 mostra os players da cadeia do Brasil para os EUA e para a Holanda. Estão inseridos os períodos médios de tempo entre as operações de cada um dos agentes, considerando apenas os trajetos região de Holambra-Campinas/São PauloMiami e região de Holambra-Campinas/São Paulo-Amsterdam. Nota-se que em ambas as cadeias há envolvimento dos mesmos agentes no Brasil. Se não ocorrerem entraves em cada uma das etapas, a diferença diz respeito basicamente aos mercados de países de destino, que possuem estruturas distintas de comercialização do produto. Apesar disso, o tempo total de entrega das flores até o consumidor final, em média, praticamente não varia muito - em torno de 5 a 6 dias - sem considerar o processo de produção e o seu tempo de sobrevivência após a compra pelo último agente na cadeia. 


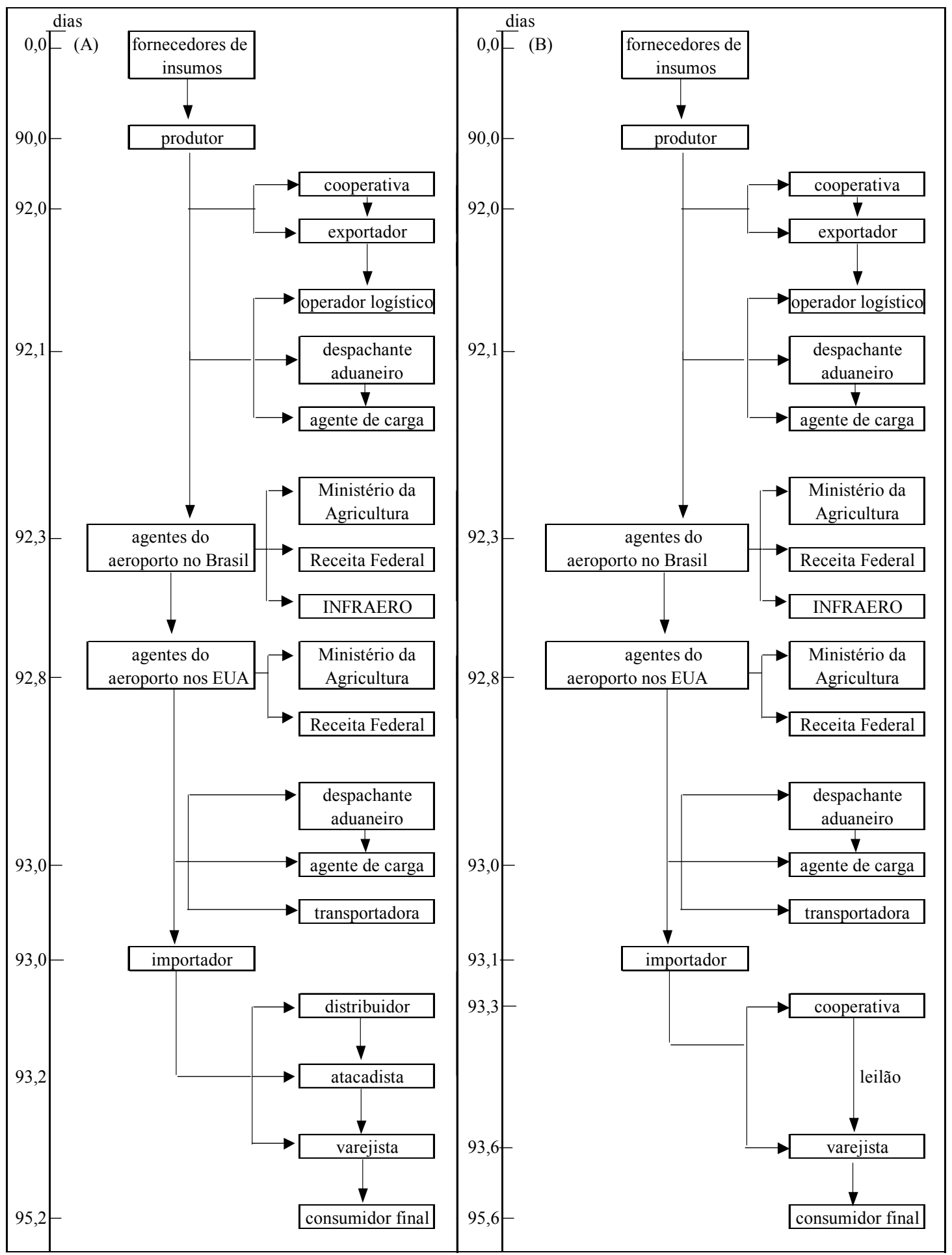

Figura 3 - Cadeias de exportação de flores Brasil-EUA (A) e Brasil-Holanda (B), a partir de informações fornecidas por especialistas do setor 
Neste caso, considerou-se ciclo médio de 90 dias, relativo às flores estudadas. As comerciais exportadoras são utilizadas para fazer a intermediação dos produtos no exterior, como alternativa para mercados em que as cooperativas não atuem de maneira efetiva. Algumas delas estão expandindo seus escritórios de representação para outros países, para estreitar as relações com atacadistas e importadores estrangeiros, agilizar o transporte das mercadorias e controlar a qualidade de seus produtos.

Os exportadores de flores não se atêm a produtos de um determinado país, mas sim buscam produtos de melhor qualidade e preços competitivos, qualquer que seja sua origem. Observa-se que, nos EUA, há relacionamento de importadores com distribuidores e atacadistas, ao contrário da Holanda, na qual as flores de corte são destinadas aos leilões. Conforme Couto (2002), esses leilões são conhecidos como clock e realizam a venda eletrônica de grande quantidade de flores, com média de 6 mil transações por dia e 1,3 segundos por lote. O Veiling Holambra utiliza o mesmo sistema de comercialização empregado na Holanda e caracteriza-se por haver seleção mais rigorosa das flores comercializadas para atingir cotações de preços mais altas. No caso de venda direta para importadores ou distribuidores, o preço segue as tendências do mercado, com poder maior de negociação entre as partes para flores de melhor qualidade.

Os grandes centros atacadistas, concentrados no Estado de São Paulo, possuem sistemas de distribuição distintos. Instituições públicas, como a Companhia de Entrepostos e Armazéns Gerais de São Paulo (CEAGESP) e a Central de Abastecimento S/A de Campinas (CEASA), estão direcionadas para o mercado interno. Agentes privados, como a Cooperativa Agropecuária Holambra (Veiling Holambra) e a empresa Floranet, já possuem experiências com o mercado externo, embora com focos no mercado interno. De acordo com Smorigo (2000), a participação desses distribuidores sobre o faturamento total acumulado de janeiro a outubro de 1999 foi de 51\%, 19\%, $25 \%$ e $5 \%$, respectivamente.

As perspectivas para a expansão do mercado no Brasil são positivas, pois de acordo com Bongers (2000), cada brasileiro gasta em média apenas US\$ 3.80 por ano com flores, enquanto gaúchos e cariocas consomem em média US\$ 13.70. Conforme 
esse autor, dentre os efeitos oriundos da primeira fase do Plano Real para a economia brasileira, a abertura das importações de produtos de menores valores agregados, como as flores artificiais, e a elevação do poder aquisitivo da população fizeram com que os consumidores criassem novos hábitos de consumo, ampliando a vontade de adquirir produtos diferentes. Por outro lado, o aumento das viagens internacionais nessa época, principalmente por pessoas de classe média, levou à disseminação bastante rápida de hábitos estrangeiros quanto à compra de flores e plantas ornamentais.

O elevado consumo anual per capita nos principais países importadores de flores brasileiras, segundo Bongers (2000), é também um estímulo à inserção do produto brasileiro no exterior. A Tabela 1 apresenta o consumo per capita de flores de corte de alguns países para 1990, 2000 e 2001. Nota-se que de 1990 a 2001 houve expansão mais acentuada de seu consumo na Noruega, Suíça, Estados Unidos, Espanha e Reino Unido. Ao se considerar apenas 2000 e 2001, destacou-se a Eslovênia, com crescimento de $58,80 \%$. Há países, como a Alemanha, Dinamarca e Irlanda, que têm contraído sensivelmente o seu consumo nesses anos. De acordo com Centre for the Promotion of Imports from Developing Countries (2002), o Reino Unido e a Alemanha continuam sendo os maiores importadores de flores de corte da Holanda. 
Tabela 1. Consumo per capita e taxas de crescimento de flores de corte de alguns países, 1990, 1994, 2000 e 2001

\begin{tabular}{lrrrrrrrr}
\hline & \multicolumn{3}{c}{ Consumo per capita (US\$) } & \multicolumn{5}{c}{ Taxa de crescimento (\%) } \\
\cline { 2 - 9 } \multicolumn{1}{c}{ País } & 1990 & 1994 & 2000 & 2001 & $1994 /$ & $2000 /$ & $2001 /$ & \multicolumn{1}{c}{ 2001/ } \\
& & & & & 1990 & 1990 & 1990 & \multicolumn{1}{c}{2000} \\
\hline Alemanha & 39.38 & 49.30 & 35.18 & 34.59 & 25,20 & $-10,70$ & $-12,20$ & $-1,70$ \\
Áustria & 32.50 & 63.47 & 39.11 & 40.00 & 95,30 & 20,30 & 23,10 & 2,30 \\
Bélgica & 34.38 & 45.60 & 36.34 & 37.43 & 32,60 & 5,70 & 8,90 & 3,00 \\
China & - & 0.00 & 0.45 & 0.55 & - & - & - & 22,20 \\
Dinamarca & 39.88 & 36.36 & 39.6 & 35.27 & $-8,80$ & $-0,70$ & $-11,60$ & $-10,90$ \\
Eslovênia & - & 16.64 & 17.04 & 27.06 & - & - & - & 58,80 \\
Espanha & 10.63 & 15.41 & 15.63 & 16.24 & 44,90 & 47,00 & 52,80 & 3,90 \\
Estados Unidos & 21.88 & 27.73 & 29.40 & 25.27 & 26,70 & 34,40 & 15,50 & $-14,10$ \\
Finlândia & - & 36.97 & 31.88 & 33.30 & - & - & - & 4,50 \\
França & 28.13 & 36.97 & 29.11 & 30.00 & 31,40 & 3,50 & 6,70 & 3,10 \\
Grécia & - & 17.87 & 12.77 & 13.30 & - & - & - & 4,20 \\
Holanda & 45.00 & 51.15 & 53.39 & 52.02 & 13,70 & 18,60 & 15,60 & $-2,60$ \\
Irlanda & 29.55 & 9.24 & 25.36 & 23.76 & $-68,70$ & $-14,20$ & $-19,60$ & $-6,30$ \\
Itália & 43.13 & 45.60 & 29.55 & 30.37 & 5,70 & $-31,50$ & $-29,60$ & 2,80 \\
Japão & 51.25 & 44.98 & 30.45 & 34.13 & $-12,20$ & $-40,60$ & $-33,40$ & 12,10 \\
Noruega & 30.00 & 65.94 & 51.25 & 52.02 & 119,80 & 70,80 & 73,40 & 1,50 \\
Portugal & - & 0.00 & 14.29 & 14.59 & - & - & - & 2,10 \\
Reino Unido & 21.88 & 22.18 & 33.3 & 32.94 & 1,40 & 52,20 & 50,60 & $-1,10$ \\
Suécia & 36.88 & 39.44 & 30.18 & 33.76 & 6,90 & $-18,20$ & $-8,50$ & 11,90 \\
Suíça & 46.88 & 112.77 & 81.61 & 79.91 & 140,60 & 74,10 & 70,50 & $-2,10$ \\
\hline
\end{tabular}

Fonte: adaptado de Flower Council of Holland (2002)

${ }^{1}$ Os dados de 1990 referem-se à Alemanha Ocidental

Não houve até recentemente incentivos à exportação de flores, mesmo nas principais regiões produtoras brasileiras. Nota-se iniciativas pontuais para a expansão das exportações por parte de alguns produtores que tiveram acesso a algum canal de exportação mais específico. De acordo com Okuda (2000), apesar de ter potencial de crescimento, o setor precisa estar mais organizado para que ocorra maior integração entre todos os elos da cadeia, desde produtor até o consumidor final. Especificamente, em relação às exportações, deve-se atentar para a falta de tradição e know-how para que se coloque o produto brasileiro no exterior. Smorigo (2000) destaca que problemas 
tributários, falta de padronização dos produtos e problemas de ordem fitossanitária constituem os principais entraves às exportações brasileiras.

De acordo com Oliveira (1995), é necessário despender uma atenção especial ao preço e à qualidade do produto com o intuito de que os processos de distribuição e comercialização de flores (especialmente as de corte) ocorram de forma mais organizada, com maior disponibilidade de informações sobre a qualidade do produto que está sendo transacionado, para que não haja insatisfação dos clientes.

No caso de rosas, por exemplo, Oliveira (1995) destaca que se deve considerar aspectos importantes para obtenção de produção adequada, tais como escolha de mudas de boa qualidade, variedades adaptadas à região de cultivo, adubação, irrigação. Além disso, tratamentos pós-colheita, padronização, classificação, embalamento e rehidratação do produto são vitais para preservar sua qualidade.

Aki (1997) acrescenta que existem divergências entre cada um dos agentes da cadeia e que tem havido um estímulo crescente à produção de flores nas mais diversas regiões, sem que tenham ocorrido ações coordenadas quanto às melhores variedades a serem utilizadas ou mesmo quanto à capacidade do mercado em absorver maior quantidade de flores. Verificou-se o plantio de flores nos Estados do Ceará e Minas Gerais, visando aumentar a produtividade, com a escolha de regiões com características edafoclimáticas mais adequadas ao plantio, além de facilitar o alcance ao mercado externo.

Dentre as empresas cearenses empenhadas em exportar destaca-se a Cearosa. Essa empresa possui perspectivas otimistas de obter alto rendimento no plantio de flores (até 200 flores $/ \mathrm{m}^{2}$ ) quando comparada com o rendimento da produção colombiana (por volta de 80 a 90 flores $/ \mathrm{m}^{2}$ ), de acordo com Demarchi (2001). Além do emprego de alta tecnologia, pode-se relacionar vantagens locais, tais como, grandes extensões de terra, inclusive as mais facilmente irrigáveis; temperaturas com pequena oscilação sazonal, variando em torno de $12^{\circ} \mathrm{C}$ durante a noite e em torno de $31{ }^{\circ} \mathrm{C}$ durante o dia; alta luminosidade - cerca de 3.000 horas de sol por ano - semelhante à Colômbia; significativa pluviosidade anual (1,5 mil de milímetros). 
Já em Minas Gerais, a família Reijers conseguiu atingir alta produtividade (em torno de 200 flores $/ \mathrm{m}^{2}$ ), bem superior à de Holambra, conforme Demarchi (2001). Concentrada no plantio de rosas, esta empresa já exporta para países como Portugal, Argentina, Paraguai e Estados Unidos.

Uma das empresas que realiza a comercialização eletrônica de flores e plantas ornamentais é a Floranet ${ }^{1}$, com sede no município de Holambra. De acordo com Rosas (2000), atua junto com a Cooperflora, que é uma cooperativa formada por 25 floricultores do sul de Minas Gerais, intermediando a venda dos produtos para atacadistas em vários locais do Brasil e do exterior. Dentre os atacadistas, deve-se citar a empresa brasileira Pot Full, que possui uma filial em Miami e atua na distribuição de flores e plantas ornamentais do Brasil, da Colômbia e do Equador para várias cidades dos Estados Unidos. De acordo com informações do setor, há também a JM Flowers, também com filial em Miami, para onde os produtos brasileiros são exportados, e Poliana Flores, que atua como exportador em alguns países da Europa e do Mercosul.

Rosas (2000) ressalta que o mercado americano exerce rigoroso controle de qualidade e fitossanidade do produto. Para distribuir produtos no Brasil e no exterior, a Pot Full tem investido em tecnologia de ponta (informática, telecomunicações, internet), administração empresarial, logística e movimentação de produtos.

De acordo com Stuani (2000), com a janela de oportunidades oferecida pelo programa brasileiro de incentivo às exportações do agronegócio, que inclui agora também o setor de flores, empresas internacionais têm sido atraídas para investirem no Brasil. Esse é o caso da Brasil Cargo Infra-Estrutura Ltda, com investimentos iniciais de US\$ 345 milhões para a construção de um parque industrial no município de Mogi Mirim, que conta inclusive com um complexo multimodal de transportes e uma Estação Aduaneira do Interior (EADI), para armazenamento, embalagem e desembaraço das mercadorias a serem enviadas ao exterior, principalmente para Europa e EUA.

\footnotetext{
${ }^{1}$ Informações disponíveis em http://www.floranet.com.br
} 
Com a implantação da Lei de Proteção de Cultivares em 25/04/1997, outras empresas poderão investir no Brasil. Essa lei no. $9.456^{2}$ foi criada com o intuito de proteger os direitos de propriedade dos cultivares, com o detalhamento de todas as ações que devem ser executadas para que essa lei seja cumprida. Santana (1997) destaca que em relação às empresas que criam variedades de rosas, já é prática comum que seja cobrado o direito autoral pelo seu cultivo em qualquer parte do mundo. Há casos de empresas que chegam a cobrar até US\$ 1.00 por planta de suas variedades cultivadas por outros produtores.

Em 2001 foi criada a BallVanZanten, que é uma joint venture, ou seja, uma união comercial da holandesa Van Zanten Schoenmaker com a Ball Horticultural, maiores produtoras de mudas de crisântemos do Brasil e de sementes de flores do mundo, respectivamente, sendo esta última sediada em Chicago. Conforme Líderes (2001), essa nova empresa tem por principal objetivo comercializar plugs, estágio intermediário entre a semente e a muda, que apesar de serem mais eficientes economicamente, ainda são pouco utilizados no Brasil.

Essa empresa veio competir com outras já instaladas no Brasil, como a japonesa Agroflora-Sakata, que tem disponibilizado aos produtores brasileiros entre 20 e 30 sementes novas todos os anos. Dentre as novas flores que têm ocupado expressiva fatia no mercado, pode-se destacar Lisianthus (com ampla variedade de cores exclusivas, durabilidade após a colheita de 15 a 20 dias, cultivares de 5 a 12 pétalas, podendo ser vendido em corte ou em vaso); girassol ornamental (que não solta pólen, sendo muito usado em arranjos, pois não suja o ambiente, com durabilidade entre 7 e 10 dias).

Uma outra iniciativa refere-se ao Programa Brasileiro de Exportação de Flores e Plantas Ornamentais (FloraBrasilis), que tem origem no convênio entre o Instituto Brasileiro de Floricultura (IBRAFLOR) e a Agência de Promoção de Exportações (APEX), firmado em outubro de 2000, para que seja conduzido em 4 anos nas regiões com produção organizada, com vistas a expandir o mercado brasileiro para Alemanha, Holanda, Japão e Estados Unidos. Apesar de estar no início de sua implantação, esse

2 Maiores detalhes sobre o seu conteúdo poderão ser encontrados em http://www.orplana.com.br/ leicultivares.htm 
programa pode se tornar uma importante iniciativa para o desenvolvimento do setor, caso as metas estabelecidas sejam alcançadas. Conforme Flores e plantas ... (2001), foram selecionados os seguintes pólos de produção: Amazonas e Pará; Bahia e Espírito Santo; Ceará; Goiás e Distrito Federal; Minas Gerais; Paraná; Pernambuco e Alagoas; Rio de Janeiro; Rio Grande do Sul; Santa Catarina; São Paulo.

Seu objetivo principal é elevar as exportações brasileiras dos US\$ 13 milhões (dados de 1999) para US\$ 80 milhões. Apesar do otimismo do setor frente ao crescimento de 30\% em 2003 (US\$ 19.4 milhões), conforme relatado por Alves (2004) e Kiyuna et al. (2004), essa meta ainda está longe de ser atingida. Para isso serão mapeadas a cadeia produtiva e as preferências dos consumidores, estão previstos investimentos em formação, capacitação e treinamento de mão-de-obra, buscar-se-á a criação de um selo de qualidade e de uma marca nacional, permitindo a qualificação do produto e haverá participação em feiras internacionais para promoção desta marca com a distribuição de material impresso. As informações coletadas nesse programa serão armazenadas em um banco de dados que dará subsídios para pesquisas do setor de flores. Este banco incluirá informações sobre os atacadistas e os varejistas, a demanda e as tendências do mercado mundial, direcionando melhor as ações dessa cadeia em termos de capacitação de mão-de-obra, técnicas de manuseio, apoio logístico, adequação de produto e embalagem.

Também para contribuir para um efetivo aumento das exportações brasileiras por meio do desenvolvimento da floricultura, foi instituído em 3 de julho de 2001 o Programa de Desenvolvimento Sustentado da Floricultura (Resolução 2866 do Banco Central $^{3}$ ). Este programa, por meio de recursos do Banco Nacional de Desenvolvimento Econômico e Social (BNDES), disponibilizou R\$ 30 milhões para investimentos no período de 01 de julho de 2001 a 30 de junho de 2002, dando suporte financeiro à implementação do programa Florabrasilis. Além disso, o produtor poderá obter crédito para investimentos fixos e semifixos relacionados à implantação ou ao melhoramento de culturas de flores para a exportação, com prazo de carência de cinco anos, taxa de juros de $8,75 \%$ ao ano, e limite de $\mathrm{R} \$ 50$ mil por pedido, que pode ser reavaliado se houver

\footnotetext{
${ }^{3}$ Essa resolução está disponível em Banco Central do Brasil http://www.bcb.gov.br
} 
comprovação da capacidade de pagamento do beneficiário, após decorrido pelo menos um ano da formalização do financiamento.

Em relação a esse programa de exportação destaca-se o Estado do Ceará, o qual está incentivando a formação de consórcios de exportadores com o apoio da APEX. Para estimular a produção local de crisântemos e flores tropicais (tais como abacaxi ornamental, dracenas, helicônias) que agradam ao gosto mais exótico de estrangeiros, de acordo com Rosas (2000), foi criado o projeto Agroflores, que permitiu aos produtores comercializarem seus produtos tanto no mercado interno quanto no exterior, com destaque para a Holanda, Alemanha e Estados Unidos, por intermédio de atacadistas de Miami. Conforme Demarchi (2001), apesar das rosas, cravos e cravinas ainda representarem em torno de $70 \%$ da demanda mundial, as flores tropicais já ganharam espaço nesse mercado, como é o caso de orquídeas, antúrios, bromélias, alpínias, musáceas e helicônias.

Ao se analisar o programa de exportação de flores brasileiras, nesse processo de qualificação e monitoramento do produto brasileiro, de acordo com Machado (2000), deve-se considerar também a rastreabilidade, que possibilita ao consumidor mais exigente a confiança no produto que está adquirindo. Permitirá, também, que se localizem possíveis falhas e se tomem medidas corretivas a custos mais baixos, a partir do conhecimento de todas as transações pelas quais o produto foi submetido até a sua origem. Na criação da marca nacional, esse componente pode se constituir num diferencial em relação aos demais países exportadores, facilitando inclusive a obtenção do selo ambiental, que é exigência do mercado europeu.

Deve-se destacar o papel da IBRAFLOR para estabelecer o padrão único de qualidade das flores brasileiras. A partir de discussões com a Câmara Setorial de Flores e Plantas Ornamentais do Estado de São Paulo, iniciadas em 1999, de acordo com Motos (1999), foram classificadas as vinte principais flores e plantas ornamentais, a partir de critérios que deverão constar nas embalagens dos produtos.

Em relação à distribuição do produto para o exterior, o transporte assume importância crucial, pois se trata de um demandante mais exigente, principalmente quanto aos prazos de entrega. As relações com as empresas aéreas e órgãos de 
fiscalização deverão ser mais estreitas, priorizando o transporte de produtos perecíveis, para que cheguem a seu destino em condições adequadas de comercialização. Em 2000, conforme Pronk (2000), a exportação de flores foi prejudicada em função de greve de funcionários do Ministério da Agricultura, responsáveis pela fiscalização e controle fitossanitários de produtos agrícolas destinados ao exterior.

Smorigo (2000) destaca que há treinamento especializado dos associados pertencentes a sistemas privados, como a cooperativa Holambra, com maior acesso a cursos de especialização e viagens técnicas à cooperativa. Dado que, de maneira geral, o cultivo de flores não demanda investimento alto de capital, uma vez que necessita de pequenas áreas para um ciclo rápido de produção, de acordo com Góes (1997), há muitos produtores, principalmente associados aos sistemas de distribuição públicos (como CEASA, CEAGESP), que não investem em treinamento especializado dos seus funcionários.

Quanto maior o investimento na marca, maior é a sua especificidade, conforme confirmado por Smorigo (2000). Assim, deve-se analisar cuidadosamente como esses processos de criação de marcas ocorreram em outros países, como a Holanda, para que sejam adequadamente implantados no Brasil. Um exemplo de sucesso, segundo Calçados (2002), é a Cooperativa de Flores Holambra, que já possui há alguns anos uma marca coletiva para produtores associados, sem que as marcas individuais sejam prejudicadas.

Para que o Brasil atinja mercados mais exigentes, deverá investir no certificado ambiental (selo verde), que já é almejado pelos concorrentes colombianos e equatorianos; caso contrário, terá dificuldade de ampliar o mercado no longo prazo. Para isso, vários elementos, tais como os sistemas de produção e transporte, os tipos de semente, pesticidas e insumos utilizados devem ser considerados no planejamento dos investimentos. No caso de flores, para que se realize controle mais intensivo de pragas e doenças, exige-se monitoramento constante e controle freqüente dessas adversidades. Outros fatores que podem contribuir para reduzir a incerteza são o manejo adequado da cultura e emprego de tecnologia. Quanto a esses dois últimos quesitos, Smorigo (2000) 
detectou que os produtores que utilizam sistemas de distribuição públicos, com menor nível tecnológico, estão mais suscetíveis à incerteza.

Segundo informações setoriais, a exportação de flores apresenta outros fatores limitantes relevantes, tais como a inexistência de câmaras frias nos aeroportos e nos próprios compartimentos de carga dos aviões.

De acordo com o estudo de Florabrasilis (2002), 51,70\% dos exportadores pesquisados estão localizados no Estado de São Paulo e utilizam em sua maioria o modal aéreo $(80 \%)$ para exportar seus produtos. Foram apontados os seguintes entraves nesse estudo para o Brasil: problemas sérios na infra-estrutura para exportação, relacionados ao certificado fitossanitário de origem, câmaras frias nos aeroportos e processo de liberação da carga nos aeroportos; importação de matrizes; qualidade do produto; idoneidade do importador; alto custo operacional para pequenas remessas, carência de produtos para elevar as exportações; preços de frete elevados; não conhecimento do produto brasileiro no exterior; falta de informação do mercado de destino; inexperiência do aeroporto e de importadores com relação ao produto.

$\mathrm{Na}$ Holanda, Elshof (1998) detectou que: há limitações no clima; necessidade de cultivo em estufas; forte dependência de fontes de energia não-renováveis; alto custo da terra; água de irrigação mais escassa; emissões de fertilizantes e defensivos no solo, água e ar; mão-de-obra cara; pequeno conhecimento de marketing; dificuldade dos produtores obterem informações atualizadas do mercado.

De acordo com Semboja, Mbelwa e Bonaventura (2000), foram identificados problemas na exportação de flores na Tanzânia, referentes ao transporte, em função de tarifas alfandegárias elevadas quando comparadas ao Quênia (US\$ 2.00/kg contra US\$ $1.50 / \mathrm{kg}$, respectivamente); à burocracia no despacho da documentação e estradas ruins até Nairobi (onde se localiza o aeroporto); a sistemas de controle de qualidade precários, apesar dos produtores terem recebido treinamento sobre controle de qualidade e embalamento do produto. 


\subsection{Logística e cadeia de suprimentos: aspectos gerais}

Apesar da divergência de objetivos dos vários agentes da cadeia de flores que fazem a distribuição interna do produto, a busca pelo ganho em vantagem competitiva por meio da competência logística é crucial para as empresas brasileiras ligadas à exportação de flores, para que possam monitorar a movimentação dos produtos em tempo real, identificar falhas operacionais e corrigir ações antes que ocorram erros no serviço ao cliente.

A abordagem sistêmica das organizações, com ênfase nos seus processos, tem se destacado como uma das maneiras das empresas obterem sucesso no fornecimento de ferramentas e metodologias de gestão da qualidade. As organizações são analisadas como sistemas abertos e dinâmicos, com troca de informações com outros players, concorrentes, clientes, fornecedores, acionistas e governo, e compostas por conjuntos de processos, sub-processos, atividades e tarefas, totalmente orientados para a melhoria do sistema a partir do envolvimento de todas as suas funções. Segundo Vara (2001), com o surgimento da norma ISO-9001: 2000, essa abordagem ganha expressão ainda maior por promover atividades de análise para os processos, à semelhança dos modelos de excelência logística.

De acordo com Almeida (1993, p.30), processo "é o conjunto de recursos humanos e materiais dedicados às atividades necessárias à produção de um resultado final específico, independentemente de relacionamentos hierárquicos”, ou seja, há quebra da departamentalização da empresa e as atividades são seqüenciadas para atingir resultados pré-estabelecidos, para agregar valor.

Em termos logísticos, a integração de processos assume papel de destaque no desempenho da empresa por meio de melhorias em serviço ao cliente, administração do nível de estoques, precisão das previsões e satisfação do cliente e do empregador. Essa integração inclui interação (troca de informação dentro da empresa) e colaboração (é necessária, mas não suficiente para promover a integração - envolve mudanças culturais dentro da empresa, pois há necessidade de trabalho conjunto, direcionado para obtenção 
de mesmo resultado, formação de unidades de esforço no acompanhamento das empresas), conforme destacam Kahn \& Mentzer (1996).

O processo logístico, definido como a administração de pedidos, estoques, materiais e serviço de entrega, é destacado por Davenport (1994) como uma das aplicações da tecnologia de informação nas empresas. Henkoff (1994) acrescenta que se busca a obtenção de vantagem competitiva por meio desses processos logísticos, a partir do melhor equacionamento de preço e qualidade dos produtos e da habilidade das empresas em entregarem a quantidade exata na hora determinada. Para isso é preciso que ocorra alteração no padrão de comportamento das pessoas. De acordo com Fawcett e Clinton (1996), o desempenho desses processos é afetado pela maneira como as empresas realizam seu planejamento logístico, pelo nível de relacionamento estabelecido com os clientes e pela forma como ocorrem as mudanças nesses processos.

Garvin (1995) destaca que a introdução de mudanças nas empresas é difícil, principalmente por envolver alterações na sua cultura e nos seus processos internos. Se o mercado estiver direcionado para consumidores localizados em países com culturas diferentes e exigências diversas, esforços na obtenção de melhor desempenho em cada uma das empresas, por meio da implementação interna de processos, podem representar um diferencial de competitividade em relação aos demais países. Esse autor também ressaltou que é difícil alterar a dinâmica e introduzir mudanças nas empresas, principalmente por envolver alterações na sua cultura e nos seus processos internos; assim, a sua reestruturação interna precisa ser cuidadosa, principalmente se forem adotados processos mais radicais, como a reengenharia.

A estratégia competitiva de uma empresa, conforme Chopra \& Meindl (2001), está relacionada à satisfação das necessidades do cliente por meio de seus produtos e serviços, ou seja, baseia-se nas prioridades dos clientes, separadas em um ou mais segmentos. Há estreita relação entre as estratégias competitivas da empresa e da cadeia, que podem ser expressas pela cadeia de valor de cada organização, que foi desenvolvida por Porter (1985). Essa cadeia refere-se ao valor adicionado de um produto que segue cada estágio do processo produtivo, consistindo-se de margem e de atividades de valor. O valor é expresso em termos de receita total e não de custos. 
Através do desenvolvimento de estratégias para coordenação de funções ligadas a finanças, contabilidade, tecnologia da informação e suporte aos recursos humanos, a cadeia poderá se articular para:

a) desenvolvimento do produto, que especifica o portfólio de novos produtos que serão desenvolvidos pela empresa;

b) marketing e vendas, que procura esclarecer como o mercado estará segmentado e estabelecer preços e promoções dos produtos;

c) cadeia de suprimento, que especifica quais operações, distribuição e serviços deverão ser realizados, sob a ótica da cadeia de valor. Abrange as decisões relacionadas aos estoques, transporte, facilidades operacionais e fluxos de informação da cadeia de suprimentos. Inclui as estratégias do fornecedor, das operações e da logística.

De acordo com Fisher (1997), a análise da natureza da demanda dos produtos ofertados pelas empresas constitui-se na primeira etapa para delinear a estratégia da cadeia de suprimentos. Pode-se classificar os produtos em funcionais e inovadores. Suas principais características estão relacionadas no Quadro 1. 


\begin{tabular}{|c|c|c|}
\hline Itens & Produto inovador & Produto funcional \\
\hline Conceito & $\begin{array}{l}\text { Contém inovações de moda ou } \\
\text { de tecnologia para que os } \\
\text { consumidores tenham uma } \\
\text { razão adicional para adquiri-los }\end{array}$ & $\begin{array}{l}\text { Satisfaz as necessidades } \\
\text { básicas dos consumidores }\end{array}$ \\
\hline Margem de lucro & Mais alta & $\begin{array}{l}\text { Mais baixa, em função da } \\
\text { competição com outros } \\
\text { produtos }\end{array}$ \\
\hline Ciclo de vida do produto & Mais curto (de 1 a 3 anos) & $\begin{array}{l}\text { Mais longo (mais de } 2 \\
\text { anos) }\end{array}$ \\
\hline $\begin{array}{l}\text { Margem de contribuição }(\%) \text { : } \\
\frac{(\text { preço-custo variável })}{\text { preço }} \times 100\end{array}$ & $20 \%$ a $60 \%$ & $5 \%$ a $20 \%$ \\
\hline Variedade do produto & $\begin{array}{l}\text { Alta (em geral há milhões de } \\
\text { variantes por categoria) }\end{array}$ & $\begin{array}{l}\text { Baixa (10 a } 20 \text { variantes } \\
\text { por categoria) }\end{array}$ \\
\hline $\begin{array}{l}\text { Margem média de erro na } \\
\text { previsão da produção }\end{array}$ & $40 \%$ a $100 \%$ & $10 \%$ \\
\hline Taxa média de stockout & $10 \%$ a $40 \%$ & $10 \%$ \\
\hline $\begin{array}{l}\text { Prazo de entrega para } \\
\text { produtos feitos por pedido }\end{array}$ & 1 dia a 2 semanas & 6 meses a 1 ano \\
\hline Tipo de demanda & Imprevisível (volátil) & $\begin{array}{l}\text { Previsível, sem muitas } \\
\text { mudanças ao longo do } \\
\text { tempo }\end{array}$ \\
\hline $\begin{array}{l}\text { Tipo de cadeia de } \\
\text { suprimentos }\end{array}$ & Responsiva (responsive) & Eficiente \\
\hline
\end{tabular}

Quadro 1 - Diferenças entre produtos funcionais e inovadores

Fonte: adaptado de Fisher (1997)

Cadeia responsiva, conforme Chopra \& Meindl (2001), diz respeito à habilidade das empresas de realizarem grandes ajustes na sua produção em função da quantidade demandada, manusear ampla variedade de produtos, gerar produtos altamente inovadores e encontrar um nível de serviço elevado; eficiência relaciona-se ao custo de produzir e entregar um produto ao cliente. Assim, se a cadeia for mais responsiva, haverá custos adicionais que reduzirão sua eficiência num primeiro momento. Como seu ciclo de vida é mais curto e com margem de lucro mais alta, há compensação nos seus ganhos em relação a cadeias mais eficientes.

De acordo com as publicações da Organização de Cooperação e Desenvolvimento Econômico (OCDE), citadas por Lopez (2000), os componentes do 
custo logístico, em termos percentuais, são os seguintes: armazenagem (20\%), estoques $(16 \%)$, transporte $(25 \%)$, empacotamento $(10 \%)$, gerenciamento e controles $(11 \%)$, administração (18\%).

Para que as empresas sejam bem sucedidas, de acordo com Chopra \& Meindl (2001), suas estratégias e as cadeias a que pertencem devem ter o mesmo objetivo. Deve haver uma interação entre as prioridades do cliente e as competências da cadeia de suprimentos para que se obtenha um ajuste estratégico. Esse ajuste é formado pela convergência entre as prioridades do consumidor e as capacidades da cadeia de suprimentos para que atinja seus objetivos estratégicos. Isso tende a repercutir diretamente no sucesso da empresa e na eficiência da cadeia. Conforme Porter (1996), ao relacionar muitas atividades, o ajuste estratégico é fundamental não apenas para obtenção de vantagem competitiva, mas também para que esta seja sustentável. Segundo McGaughey, Snyder \& Carr (1994, p.273), vantagem competitiva diz respeito à "habilidade de se sobressair no mercado devido ao preço, ao produto, ao nível de serviço ou ao desempenho".

Diante de mudanças no ambiente competitivo, há necessidade de maior integração não apenas dentro da empresa, mas também da cadeia de abastecimento como um todo. É nesse contexto que surgiram os conceitos de logística integrada (LI) e gestão da cadeia de suprimentos (supply chain management, SCM), ambos direcionados para satisfazer o cliente a partir de uma visão mais sistêmica da estratégia dos negócios. Tais conceitos podem constituir pontos-chave para o melhor desempenho estratégico da cadeia como um todo e redução dos conflitos entre os agentes. Vorst, Dijk \& Beulens (2001), por exemplo, desenvolveram um modelo aplicado à cadeia de aves na Holanda e observaram restrições na sua coordenação devido a limitações na colaboração entre alguns agentes.

De acordo com Council of Logistics Management ${ }^{4}$, logística integrada é o processo da cadeia de suprimentos que planeja, implementa e controla o fluxo e o estoque de bens e serviços e as informações desde o ponto de origem até o de consumo, de maneira eficiente e eficaz, buscando a satisfação das necessidades do cliente. Wood \& Zuffo

\footnotetext{
${ }^{4}$ Informações disponíveis em http://www.clm1.org
} 
(1998) tratam a logística integrada em termos de criação de coordenadorias de logística para cada uma das unidades de negócios, aglutinando em cada uma das áreas todas as funções logísticas, desde a recepção de matérias-primas e suprimentos, passando pelo planejamento, controle da produção e da distribuição de produtos acabados.

A cadeia de suprimentos, segundo Chopra \& Meindl (2001), tem como principal objetivo satisfazer as necessidades do consumidor, procurando maximizar os valores gerados ao longo da cadeia, que são fortemente correlacionados com a sua lucratividade. Para isso, ela envolve um fluxo constante de informação, produto e capital entre os diferentes estágios, os quais incluem desde fornecedores de matérias-primas, fabricantes, distribuidores, atacadistas, varejistas até consumidores. Deve-se, no entanto, ressaltar que o consumidor é a origem da renda, qualquer que seja a cadeia de suprimentos considerada. Como as empresas são muito influenciadas pela renda obtida e pelo custo das operações, as decisões da cadeia têm um impacto grande no sucesso ou fracasso de cada firma.

De acordo com Cooper, Lambert \& Pagh (1997), nas empresas de tecnologia avançada há concorrência real entre cadeias de suprimento e não entre empresas. Por outro lado, nem todos os elos dentro de cada cadeia devem ser estreitamente coordenados e integrados, pois as empresas deverão escolher o nível de parceria mais adequado a um conjunto específico de circunstâncias.

Para o caso da cadeia de flores, dada a forte assimetria informacional entre todos os seus elos, relatada por vários autores (entre eles, Okuda, 2000; Aki, 1997; e Oliveira, 1995), há um custo muito alto devido ao viés da informação ao longo da cadeia. A eficiência da cadeia será maior se houver integração entre os agentes, por meio de mudança nos seus hábitos, na sua coordenação e com investimento efetivo em capital humano.

Para monitorar todas as atividades associadas à movimentação de bens, das matérias-primas ao consumidor final, são necessários sistemas de informação. Segundo Lummus \& Vokurka (1999), a gestão da cadeia de suprimentos pode ser considerada como um fator de diferenciação para uma empresa, desde que todos os componentes da cadeia possam encontrar objetivos estratégicos. Esses autores acrescentam que empresas 
com sucesso na integração da cadeia relataram investimentos mais baixos em estoques, redução do tempo do ciclo do fluxo de caixa, menor custo de aquisição de materiais, produtividade mais alta dos funcionários, aumento na habilidade de encontrar datas exigidas pelos clientes e custos logísticos menores.

Gestão da cadeia de suprimentos, de acordo Chopra \& Meindl (2001, p.6), envolve o "gerenciamento dos fluxos entre todos os estágios da cadeia de suprimentos com o intuito de maximizar a lucratividade total". Constitui-se numa metodologia que tem por objetivo alinhar, de forma sincronizada, todas as atividades de produção por meio da administração de todos os processos do negócio, não apenas da logística. É, portanto, uma ferramenta estratégica utilizada para elevar a satisfação do cliente e a competitividade da empresa.

Para que ocorra uma tomada de decisão com substantivo impacto na lucratividade e sucesso ao longo do gerenciamento da cadeia, Chopra \& Meindl (2001) ressaltam que devem ser levadas em conta três fases ou categorias da cadeia:

a) estratégia ou delineamento, onde se decide qual a configuração e processos de decisão utilizados em cada estágio. Como são decisões de longo prazo, que incluem altos custos, deve-se levar em conta a incerteza ao se antecipar as condições de mercado nos anos subseqüentes;

b) planejamento, isto é, a partir do delineamento é definido um conjunto de políticas de curto prazo para administrar essas operações, incluindo alguns parâmetros nas decisões dessa fase, tais como incerteza da demanda, taxas de câmbio e competição nesse espaço de tempo mais reduzido;

c) operação, sendo que nesta fase as empresas tomam decisões relativas aos pedidos individuais dos clientes, que podem ser realizadas semanalmente ou mesmo diariamente (curtíssimo prazo). Nesta fase procura-se minimizar a incerteza e otimizar o desempenho a partir das configurações estabelecidas nas categorias anteriores.

Como a logística integrada está focada estrategicamente nas empresas, constituise na base sólida para o desenvolvimento da gestão da cadeia de suprimentos, que por 
sua vez objetiva atingir toda a cadeia de suprimentos. Há, portanto, grande interface entre esses dois conceitos apesar da logística integrada estar centrada na parte operacional. Dentre os principais entraves da gestão da cadeia de suprimentos pode-se relacionar: estrutura organizacional, compartilhamento de riscos e ganhos, transparência, confiabilidade e estratégia conjunta.

Dentre os já com experiências com o mercado externo, os principais obstáculos existentes na cadeia, que podem dificultar a habilidade das empresas em maximizarem seu lucro, segundo Chopra \& Meindl (2001), pode-se relacionar:

a) aumento na variedade de produtos, que tende a ampliar a incerteza, elevando o custo e diminuindo a responsividade dentro da cadeia;

b) redução no ciclo de vida dos produtos, elevando a incerteza e reduzindo as oportunidades dentro de cada cadeia;

c) incremento na demanda dos clientes, que costumam exigir produtos de melhor qualidade sem que os preços se alterem, aumentando os desafios para sua manutenção no mercado;

d) fragmentação da propriedade da cadeia de suprimentos, em função da menor verticalização das empresas. Uma nova estrutura de propriedade tem se formado, dificultando o gerenciamento e a coordenação da cadeia, em função de inserção de novas políticas e interesses;

e) a partir da intensificação do processo de globalização nos últimos anos, foram criadas cadeias mais complexas, com mais benefícios para fornecer produtos mais baratos. Porém, tornou mais difícil a coordenação da cadeia;

f) dificuldade de se executar novas estratégias, em função da complexidade de sua implantação.

De acordo com Chopra \& Meindl (2001), a informação entre os integrantes da cadeia constitui-se num dos principais determinantes de seu desempenho, especialmente em decorrência do aumento da importância da tecnologia da informação. Apesar de não possuir presença física, a informação afeta toda a cadeia de suprimentos, podendo reduzir custos e melhorar a sua responsividade. 
A falta de coordenação na cadeia pode se originar de distorções na informação entre os agentes, ou mesmo da priorização de objetivos e lucros em cada elo, sem levar em conta os demais. Chopra \& Meindl (2001) destacam que essa situação pode conduzir a um desempenho da cadeia abaixo do esperado, acarretando em efeito chicote (bullwhip effect), na medida em que forem verificadas variações cada vez maiores nos pedidos demandados, desde a sua produção até o consumidor final, gerando aumento nos custos de produção, de estoques, de transporte e de distribuição, no tempo de reposição do produto, e redução no nível de disponibilidade da mercadoria e da lucratividade da cadeia.

Conforme Lee, Padmanabhan e Whang (1997), esse efeito pode ser ocasionado principalmente por previsões da demanda desatualizadas, gerando oscilações inesperadas em termos de pedidos; lotes de pedidos muito grandes, que ao esperar atingir volume para suprir a demanda podem acarretar em ineficiência no atendimento desses pedidos; flutuação dos preços, ocorridas a partir de promoções ou descontos, que causam custos extras no abastecimento, transporte e armazenamento dos produtos por parte do produtor ou fábrica. Segundo Donovan (2002), o efeito chicote pode ser amenizado se houver melhoria de informação entre fornecedores e seus clientes sobre os padrões de oferta e demanda dos produtos.

Ao se analisar a logística no contexto da economia global, além de seus custos serem mais elevados, conforme Bowersox \& Closs (1996), ocorre um aumento da incerteza, principalmente em decorrência de distâncias maiores a serem percorridas, prazos de entrega maiores, menor conhecimento do mercado e redução da capacidade de controle das operações, relativo às necessidades dos clientes e restrições de comércio no âmbito internacional. Para que as empresas possam se adequar a esse novo contexto é necessário que alterem as suas estruturas organizacionais. Dornier et al. (2000) ressaltam a importância da cooperação entre organizações e do ambiente como fator de influência na coordenação e resolução de conflitos, principalmente na área logística.

De acordo com Novaes (2002), a gestão da cadeia de suprimentos está num nível de planejamento estratégico para a atuação mais integrada das empresas, que se torna cada vez mais relevante em função de fatores, tais como, maior proximidade de 
mercados, manutenção ou ampliação de posições nos mercados e redução de custos globais.

Klein, Frazier e Roth (1990) sugerem que no caso do mercado internacional, deve-se levar em conta também o volume transacionado e o custo de produção para se avaliar o nível de integração da cadeia, uma vez que ocorrem incertezas, refletidas por volatilidades dos mercados e diversidades ambientais. No Apêndice 1, como referência, estão relacionadas as principais práticas operacionais relacionadas à exportação de produtos brasileiros.

Assim sendo, a análise desses fatores relevantes através de ferramentas adequadas podem conduzir a alternativas para o melhor funcionamento dos processos logísticos da cadeia de flores. Por meio de cenários logísticos pode-se, por exemplo, avaliar as alterações que a existência ou não de câmaras frias nos aeroportos pode causar em cada um dos agentes e na cadeia como um todo. 


\section{MATERIAL E MÉTODOS}

Neste capítulo serão apresentados os dados coletados para a condução deste estudo e o método utilizado para a análise dos processos logísticos da cadeia de flores de corte.

\subsection{Ambiente a ser estudado}

O ambiente a ser modelado neste trabalho, e conseqüentemente as fontes de dados a serem contatadas, dizem respeito a produtores, cooperativas, despachantes aduaneiros, exportadores e importadores, localizados na região de Holambra e na Grande São Paulo, relacionados a cada um dos processos de exportação de flores, ou seja, de produção (A), de distribuição interna via modal rodoviário (B), de distribuição externa via modal aéreo (C) e de distribuição externa via modal rodoviário (D). Foram aplicados questionários, reproduzidos no Anexo A, preferencialmente por meio de entrevistas pessoais. Em alguns casos, em função das limitações de tempo dos entrevistados para o fornecimento de dados mais detalhados, optou-se por enviar os questionários por e-mail.

Em função da dificuldade na obtenção dos dados primários necessários, restringiu-se a análise da cadeia. Partiu-se da produção de dois tipos distintos de flores de corte - lírio e gérbera - com destino à exportação aos EUA. Foram estudados três produtores de flores, sendo um de lírio e dois de gérbera. Para distinguir estes dois últimos adotou-se a denominação gérbera 1 e gérbera 2 a partir deste capítulo. No Apêndice 2 estão relacionadas as principais características técnicas dessas flores. Considerou-se que foram distribuídas utilizando-se os mesmos canais de comercialização, tendo como base os anos 2002 e 2003 para realizar as análises anuais. 
Os dados coletados a partir de cada agente da cadeia foram relativos apenas às atividades de exportação, uma vez que há também flores produzidas e distribuídas no mercado interno. Como a análise é realizada por processo e não por agente, cada etapa pode agregar informações de um ou mais agentes para compor os valores de custos e receitas associados a cada etapa.

\subsection{Modelo insumo-produto}

De acordo com Miller \& Blair (1985) os $n$ setores da economia possuem relações fundamentais com a teoria de insumo-produto, expressas pela eq.(1).

$$
\sum_{j=1}^{n} z_{i j}+C_{i}+G_{i}+I_{i}+E_{i}=X_{i}
$$

onde:

$z_{i j}$ é a produção do setor $i$ utilizada como insumo intermediário pelo setor $j$;

$C_{i}$ é a produção do setor $i$ comprada pelas famílias;

$G_{i}$ é a produção do setor $i$ comprada pelo governo;

$I_{i}$ é a produção do setor $i$ destinada ao investimento;

$E_{i}$ é a produção do setor $i$ destinada à exportação;

$X_{i}$ é a produção doméstica total do setor $i$ (demanda final e insumos intermediários);

$C_{i}+G_{i}+I_{i}$ é a demanda final doméstica;

A demanda final da produção do setor $i, Y_{i}$, é obtida pela soma das produções do setor $i$ que são compradas pelas famílias e pelo governo, e que são destinadas ao investimento e à exportação, conforme mostra a eq.(2).

$$
Y_{i}=C_{i}+G_{i}+I_{i}+E_{i}
$$

Os principais pressupostos da teoria de insumo-produto são os seguintes: a) equilíbrio geral na economia a um dado nível de preços; b) inexistência de ilusão 
monetária por parte dos agentes econômicos; c) retornos constantes a escala; d) preços constantes.

No sistema de Leontief consideram-se retornos constantes à escala, ou seja, as funções de produção são lineares e homogêneas e o conjunto dos coeficientes técnicos diretos $a_{i j}\left(a_{i j}=z_{i j} / X_{j}\right)$, que forma a matriz $\mathbf{A}$ (de dimensão $n \times n$ ), é fixo. Esse coeficiente $a_{i j}$ expressa a quantidade de insumo do setor $i$ necessária para a produção de uma unidade de produto total do setor $j$, em que $X_{j}$ é a produção total do setor $j$.

A representação matricial do sistema aberto de Leontief está expressa na eq.(3). Seus elementos representam a proporção dos insumos por unidade do produto final fixa.

$$
\mathbf{A X}+\mathbf{Y}=\mathbf{X}
$$

onde: $\mathbf{X}$ e $\mathbf{Y}$ são os vetores coluna de ordem $(n \times 1)$.

Ao considerar que as variações na demanda final são obtidas exogenamente, pode-se expressar a produção total necessária para satisfazer a demanda final ( $\mathbf{Y}$ ) da seguinte forma:

$$
\mathbf{X}=(\mathbf{I}-\mathbf{A})^{-1} \mathbf{Y}
$$

onde:

$(\mathbf{I}-\mathbf{A})^{-1}$ é a matriz de coeficientes técnicos de insumos diretos e indiretos ou matriz inversa de Leontief.

Para a análise do modelo insumo-produto há quatro enfoques que podem ser utilizados: setor $\mathrm{x}$ setor, setor $\mathrm{x}$ produto, produto $\mathrm{x}$ setor, produto $\mathrm{x}$ produto. $\mathrm{O}$ mais adotado é o setor $\mathrm{x}$ setor com abordagem da tecnologia baseada na indústria, que tem como hipótese a existência de participação constante de cada setor no mercado. Como cada setor terá elevação proporcional na sua demanda final se houver aumento no mercado, pode-se analisar melhor a interação entre os setores da economia. 
Em estudo realizado por Anefalos \& Guilhoto (2003), foi aplicada a análise insumo-produto para o setor de flores e plantas ornamentais no Brasil com base no ano 2000, a partir da desagregação do setor agropecuário. Verificou-se que esse setor, apesar de ainda pouco desenvolvido em relação às exportações, apresenta potencial de expansão, principalmente em função dos resultados obtidos com o indicador de geração de empregos. Nesse sentido, se forem implementadas políticas com o intuito de desenvolver o setor, poderá haver incrementos na sua produção e na mão-de-obra rural.

O modelo insumo-produto de Leontief vem sendo utilizado mais freqüentemente para analisar as relações entre os setores de uma economia, que pode ser de determinado estado, região ou país ou pode haver comparação de setores de regiões de um mesmo país ou de blocos econômicos, por exemplo, o Mercosul.

Como a hipótese de tecnologia baseada na indústria assume que os processos de produção são os mesmos para todos produtos gerados dentro de um mesmo setor, análises mais detalhadas dentro de um mesmo setor podem ser realizadas a partir de modelo insumo-produto, com base nos processos de produção.

Ambos os modelos partem do sistema Leontief, ou seja, de funções de produção lineares e homogêneas e de coeficientes técnicos diretos e indiretos, que captam a interdependência econômica. Além disso, utilizam os mesmos pressupostos da teoria insumo-produto, já descritos no início desta subseção. Com o emprego de dados mais agregados (não se consideram informações específicas de setores ou processos), pode-se estar sujeito a distorções nos resultados do modelo.

Na composição do modelo insumo-produto de processo é considerado apenas um setor e são analisadas as relações entre os processos de produção. Para isso, a exportação de flores foi desagregada em insumos primários, de produção e logísticos para que o desempenho da cadeia, principalmente em termos logísticos, pudesse ser melhor analisado. 


\subsubsection{Modelo insumo-produto de processo}

Há várias estruturas teóricas mais comumente utilizadas para a análise da cadeia de suprimento. Beamon (1998) classificou os modelos da cadeia de suprimentos em quatro grupos: determinísticos (não-probabilísticos); estocásticos (probabilísticos); econômicos; de simulação. Min \& Zhou (2002) aprimoraram a taxonomia de modelos proposta por Beamon (1998) substituindo as duas últimas categorias por híbridos e com análise da tecnologia de informação (TI), conforme pode ser visto na Figura 4.

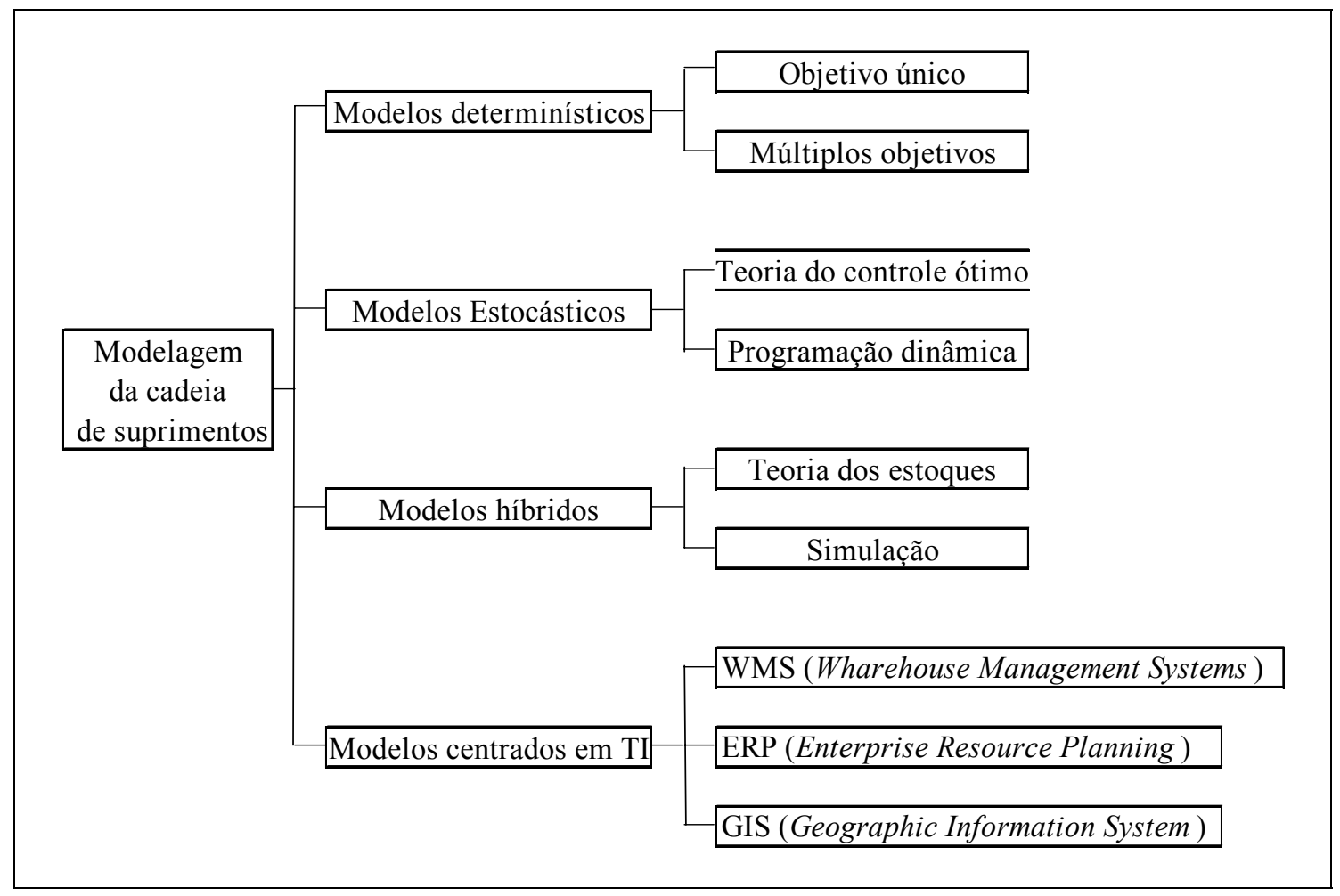

Figura 4 - Taxonomia dos modelos da cadeia de suprimentos

Fonte: Min \& Zhou (2002)

Além desses enfoques, de acordo com Albino, Izzo \& Kühtz (2002), há uma outra linha de estudo da cadeia de suprimentos, que a analisa como um sistema insumoproduto. Neste caso, pode-se estudar as redes de processos envolvidas na produção de bens e serviços a partir das relações entre firmas e entre consumidores e fornecedores, 
permitindo entendimento das relações entre os agentes e também da estrutura de governança do sistema de produção.

Ao invés de analisar os setores com base em tabelas de insumo-produto, o modelo contempla os agentes das empresas ou da cadeia como um todo. A Figura 5 descreve os quatro estágios de um modelo simples referente a uma dada organização. Os insumos são transformados em produtos finais por meio do processo, tendo como principal objetivo obter a satisfação do cliente. Edgeman (1998) relaciona como algumas medidas mais comuns de desempenho desse modelo: valor do cliente (medido por redução nos custos); custos de produção; cadeia responsiva e/ou tempo de ciclo do processo; defeitos do produto final; produtividade e utilização de recursos; segurança pública e/ou responsabilidades legais (tais como taxas de acidente, de ausência dos empregados).

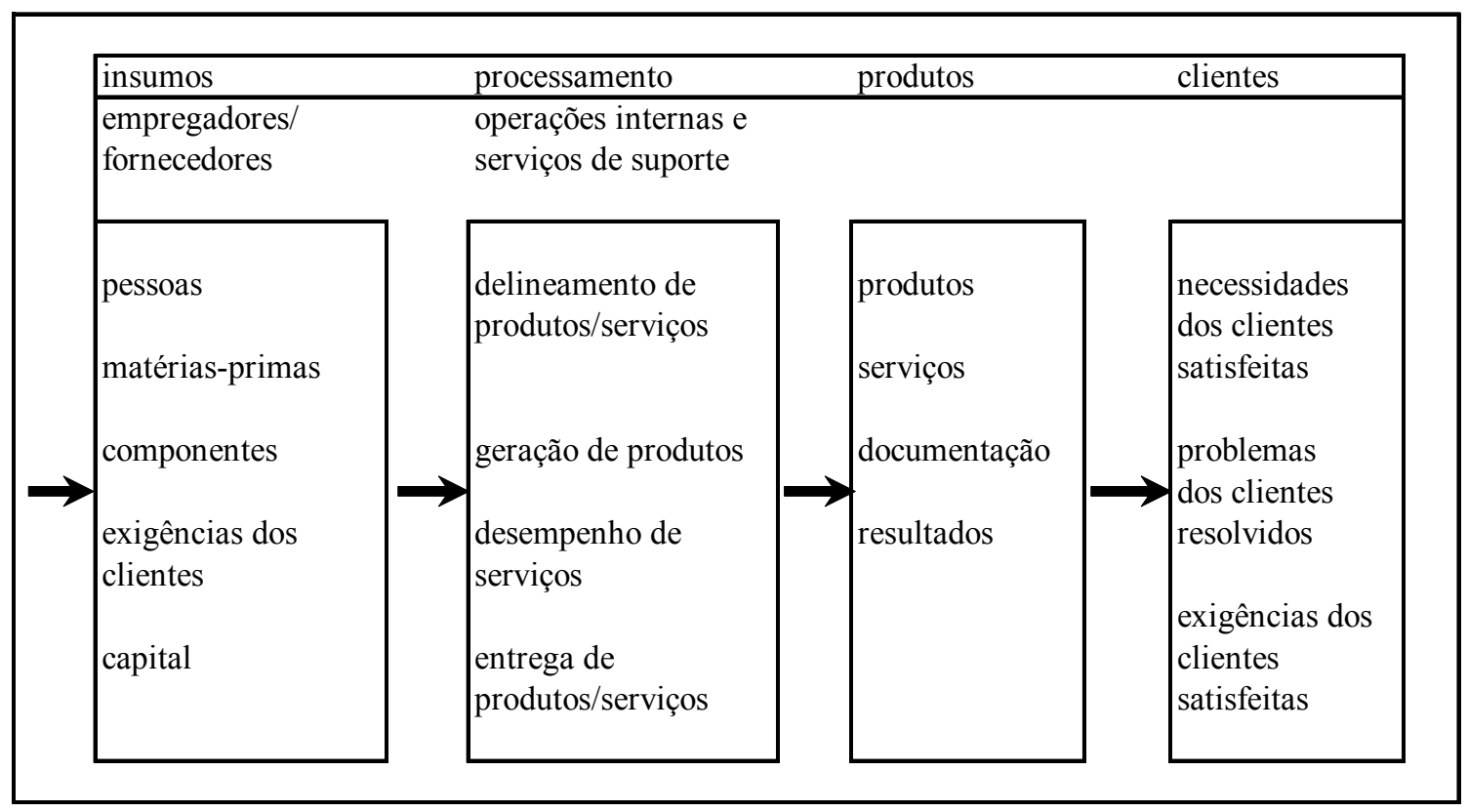

Figura 5 - Modelo insumo-produto de processo

Fonte: adaptado de Edgeman (1998)

Lin \& Polenske (1998) propuseram um modelo insumo-produto no qual as unidades básicas do modelo são processos de produção, e não produtos (e/ou commodities) ou divisões (e/ou plantas) dentro de uma empresa. Os autores destacam 
que esse modelo constituiu um avanço significativo quando comparado a estudos anteriores, que utilizavam modelos enterprise input-output (EIO) e não levavam em conta os processos de produção. Polenske \& McMichael (2002) modificaram o modelo de Lin \& Polenske para analisar o fluxo de processos das empresas, a fim de fornecer subsídios para a implementação de políticas ambientais na China.

Albino, Izzo \& Kühtz (2002) também aperfeiçoaram o modelo proposto por Lin \& Polenske (1998) analisando a cadeia de suprimentos como um todo, dividindo os processos de produção de acordo com a sua localização espacial: cadeias locais, nas quais os processos estão distribuídos dentro de uma área geográfica específica; cadeias globais, que incorporam os processos de produção da cadeia como um todo, espalhados em vários locais. Deve-se ressaltar que em ambos os modelos, os autores analisaram os impactos dos processos para o melhor manejo ambiental de determinada área.

De acordo com Vidal \& Goetschalckx (1997), a solução de modelos matemáticos com enfoque global torna-se mais complexa e difícil, pois há fatores críticos para o seu delineamento estratégico que não são incluídos, tais como, fontes de incerteza, infraestrutura de determinado país e estabilidade do governo. Conforme Polenske (2001), cada tipo de cadeia possui exigências diferentes quanto à sua produção e distribuição. Para que haja sua coordenação alguns elementos devem ser controlados, como transporte, gerenciamento de estoques e monitoramento de seu desempenho. A análise das atividades pode auxiliar cada empresa a tornar-se mais competitiva e reduzir seus custos.

A estrutura básica dos modelos propostos por Lin \& Polenske (1998) e Albino, Izzo \& Kühtz (2002) são descritas no Quadro 2. 


\begin{tabular}{|c|c|c|c|c|c|c|}
\hline \multirow[t]{2}{*}{ Processos de produção } & \multicolumn{5}{|c|}{ Processos de produção } & Demanda total \\
\hline & $\mathbf{A}$ & B & $\ldots$ & G & $\mathbf{H}$ & $Y_{i}$ \\
\hline A & $Z_{A A}$ & $Z_{A B}$ & $\ldots$ & $Z_{A G}$ & $Z_{A H}$ & $Y_{A}$ \\
\hline B & $Z_{B A}$ & $Z_{B B}$ & $\ldots$ & $Z_{B G}$ & $Z_{B H}$ & $Y_{B}$ \\
\hline$\ldots$ & $\ldots$ & $\ldots$ & $\ldots$ & $\ldots$ & $\ldots$ & $\ldots$ \\
\hline $\mathrm{G}$ & $Z_{G A}$ & $Z_{G B}$ & $\ldots$ & $Z_{G G}$ & $Z_{G H}$ & $Y_{G}$ \\
\hline $\mathrm{H}$ & $Z_{H A}$ & $Z_{H B}$ & $\ldots$ & $Z_{H G}$ & $Z_{H H}$ & $Y_{H}$ \\
\hline Processos de produção & \multicolumn{5}{|c|}{ Importações dos principais produtos $\left(M_{i}\right)^{1}$} & $M i$ \\
\hline $\mathrm{B}$ & $M_{B A}$ & $M_{B B}$ & $\ldots$ & $M_{B G}$ & $M_{B H}$ & $M_{B}$ \\
\hline $\mathrm{C}$ & $M_{C A}$ & $M_{C B}$ & $\ldots$ & $M_{C G}$ & $M_{C H}$ & $M_{C}$ \\
\hline $\begin{array}{l}\text { Tipos de insumos } \\
\text { adquiridos }\end{array}$ & \multicolumn{5}{|c|}{ Insumos adquiridos $\left(\mathrm{I}_{k j}\right)$} & $I_{k}$ \\
\hline 1 & $I_{1 A}$ & $I_{I B}$ & $\ldots$ & $I_{l G}$ & $I_{1 H}$ & $I_{1}$ \\
\hline 2 & $I_{2 A}$ & $I_{2 B}$ & ... & $I_{2 G}$ & $I_{2 H}$ & $I_{2}$ \\
\hline 3 & $I_{3 A}$ & $I_{3 B}$ & $\ldots$ & $I_{3 G}$ & $I_{3 H}$ & $I_{3}$ \\
\hline $\begin{array}{l}\text { Componentes produzidos } \\
\text { durante o processo de } \\
\text { produção e resíduos }\end{array}$ & \multicolumn{5}{|c|}{$\begin{array}{l}\text { Produções dos componentes e dos resíduos } \\
\qquad\left(W_{k i}\right)\end{array}$} & $W_{k}$ \\
\hline $\begin{array}{l}1 \\
2\end{array}$ & $\begin{array}{l}W_{1 A} \\
W_{2 A}\end{array}$ & $\begin{array}{l}W_{1 B} \\
W_{2 B}\end{array}$ & $\begin{array}{l}\cdots \\
\ldots\end{array}$ & $\begin{array}{l}W_{1 G} \\
W_{2 G}\end{array}$ & $\begin{array}{l}W_{1 H} \\
W_{2 H}\end{array}$ & $\begin{array}{l}W_{1} \\
W_{2}\end{array}$ \\
\hline Insumos primários & \multicolumn{5}{|c|}{ Consumo de insumos primários $\left(V_{k j}\right)^{2}$} & \\
\hline 1 & $V_{1 A}$ & $V_{1 B}$ & $\ldots$ & $V_{l G}$ & $V_{l H}$ & $V_{1}$ \\
\hline 2 & $V_{2 A}$ & $V_{2 B}$ & $\ldots$ & $V_{2 G}$ & $V_{2 H}$ & $V_{2}$ \\
\hline $\begin{array}{l}\text { Produção bruta dos } \\
\text { principais produtos }\left(X_{j}\right)\end{array}$ & $X_{A}$ & $X_{B}$ & $\ldots$ & $X_{G}$ & $X_{H}$ & \\
\hline
\end{tabular}

Quadro 2 - Componentes do modelo insumo-produto de processo para determinada empresa ou cadeias de suprimentos global e local

Fonte: adaptado de Lin \& Polenske (1998) e Albino, Izzo \& Kühtz (2002)

${ }^{1}$ Importações dos principais produtos $\left(\mathrm{M}_{i}\right)$ estão presentes apenas em cadeias locais

${ }^{2}$ Consumo de insumos primários $\left(V_{k j}\right)$, tais como, terra, capital, trabalho, refere-se apenas ao modelo de empresa

De forma mais detalhada, as equações a seguir descrevem as relações entre os componentes do modelo.

$$
\sum_{j} Z_{i j}=Y_{i} \quad \forall i
$$

onde: 
$\mathbf{Z}=\left[Z_{i j}\right]$ é a matriz de consumo intermediário dos principais produtos, ou seja, representa o quanto da produção total do processo de produção $j$ é utilizada para produzir uma unidade de demanda final do processo de produção $i$; $\mathbf{Y}=\left[Y_{i}\right]$ é o vetor de demanda final dos principais produtos.

$$
\mathbf{Y}=\mathbf{A X}=\mathbf{Z T}
$$

onde:

$\mathbf{A}=\left[A_{i j}\right]$ é a matriz de coeficientes diretos de insumo-produto para as principais produções dos produtos;

$\mathbf{X}=\left[Z_{j j}\right]=\left[X_{j}\right]$ é o vetor de produção do produto principal bruto no $j$-ésimo processo; $\mathbf{T}=\left[T_{j 1}\right], \quad \mathrm{T}_{j 1}=1$ é o vetor coluna unitário.

$$
\mathbf{X}^{\mathbf{i}}=\mathbf{B X}=\mathbf{I T}
$$

onde:

$\mathbf{X}^{\mathbf{i}}$ é o vetor do total de consumo de cada insumo adquirido $k$, para $k=1,2, \ldots, i$;

$\mathbf{I}=\left[I_{k j}\right]$ é a matriz de consumo de insumos adquiridos $k$ no processo $j$;

$\mathbf{B}=\left[B_{k j}\right]$ é a matriz de coeficientes diretos de insumo-produto para insumos adquiridos $k$ no processo $j$.

$$
\mathbf{X}^{\mathbf{w}}=\mathbf{C X}=\mathbf{W T}
$$

onde:

$\mathbf{X}^{\mathbf{w}}$ é o vetor do total de produção de cada um dos componentes intermediários e resíduos $k$, para $k=1,2, \ldots, w$;

$\mathbf{W}=\left[W_{k j}\right]$ é a matriz de produção de componentes intermediários e resíduos $k$ no processo $j$ 
$\mathbf{C}=\left[C_{k j}\right]$ é a matriz de coeficientes diretos de insumo-produto para componentes intermediários e resíduos $k$ no processo $j$.

$$
\mathbf{X}^{\mathbf{Z}}+\mathbf{X}^{\mathbf{m}}=\mathbf{A X}=(\mathbf{Z}+\mathbf{M}) \mathbf{T}
$$

onde:

$\mathbf{X}^{\mathbf{m}}$ é o vetor do total de importações de cada um dos principais produtos $k$, para $k=1,2$, ..., $m$;

$\mathbf{X}^{\mathbf{Z}}=\mathbf{Z T}=\mathbf{Y}$ é o vetor de consumo intermediário dos principais produtos;

$\mathbf{M}=\left[M_{i j}\right]$ é a matriz de importações dos principais produtos provenientes do processo $i$ para o processo $j$.

$$
\mathbf{X}^{\mathbf{v}}=\mathbf{D X}=\mathbf{V T}
$$

onde:

$\mathbf{X}^{\mathbf{v}}$ é o vetor do total de consumo de cada insumo primário $k$;

$\mathbf{V}=\left[V_{k j}\right]$ é a matriz de consumo de insumos primários $k$ no processo $j$;

$\mathbf{D}=\left[D_{k j}\right]$ é a matriz de coeficientes diretos de insumo-produto para insumos primários $k$ no processo $j$.

Deve-se ressaltar que os coeficientes $A_{i j}, B_{k j}, C_{k j}$ e $\mathrm{D}_{k j}$, relativos a determinada empresa e/ou cadeia de suprimento, são estimados.

De acordo com Lin \& Polenske (1998), a determinação de quais produtos constituem os principais bens do processo depende, sobretudo, das exigências do tipo de informação utilizada e das necessidades analíticas, não afetando a estrutura do modelo, apenas de algumas matrizes. A Figura 6 mostra a representação esquemática desses dois modelos. Deve-se esclarecer que as informações técnicas do processo referem-se às matrizes $\mathbf{Z}, \mathbf{I}, \mathbf{M}, \mathbf{W}, \mathbf{V}$ e $\mathbf{X}$; os coeficientes diretos de insumo-produto são obtidos através da relação entre cada elemento da matriz $Z$ e o seu total para cada um dos 
processos; coeficientes totais são calculados em relação à demanda final; estrutura de receita e custo é obtida a partir de dados de preço, quantidade e receita ou custo dos principais produtos e insumos de cada empresa da cadeia.

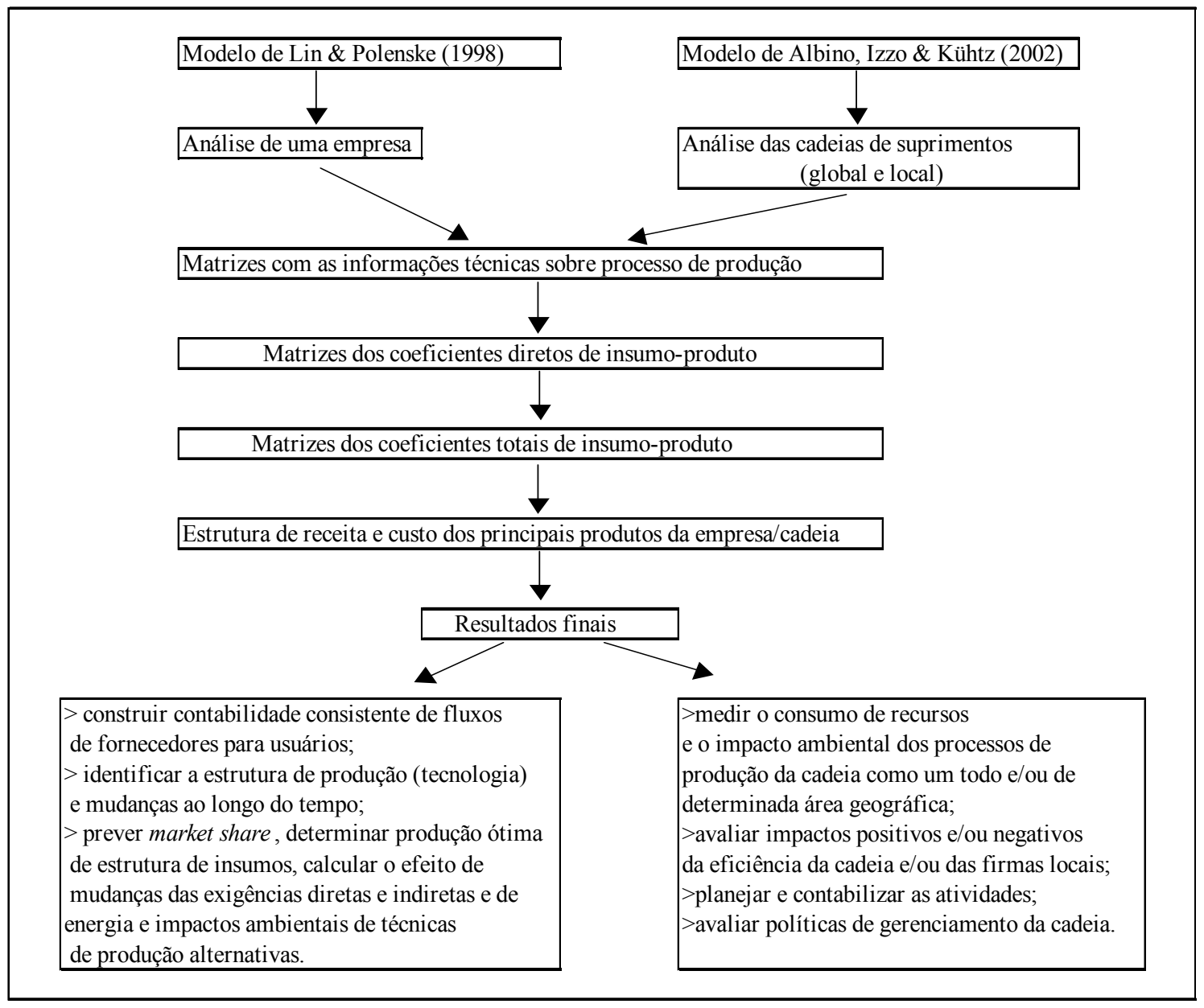

Figura 6 - Representação esquemática dos modelos propostos

Fonte: adaptado de Lin \& Polenske (1998) e Albino, Izzo \& Kühtz (2002) 


\subsubsection{Modelo proposto para exportação de flores de corte}

Para analisar a cadeia de exportação de flores de corte, propõe-se um modelo insumo-produto de processo, desenvolvido a partir dos modelos de Lin \& Polenske (1998) e Albino, Izzo \& Kühtz (2002). Para isso foram contempladas as seguintes etapas:

\section{(1) Identificação dos componentes do modelo}

A Figura 7 apresenta o modelo, no qual estão identificados os processos de produção (de A a E), os produtos mais importantes da cadeia de flores de corte e os seus principais agentes. Esse modelo foi estruturado a partir de informações de agentes do setor. Vale acrescentar que os insumos considerados também incluem alguns componentes logísticos, como prazos de entrega de insumos e produtos. 


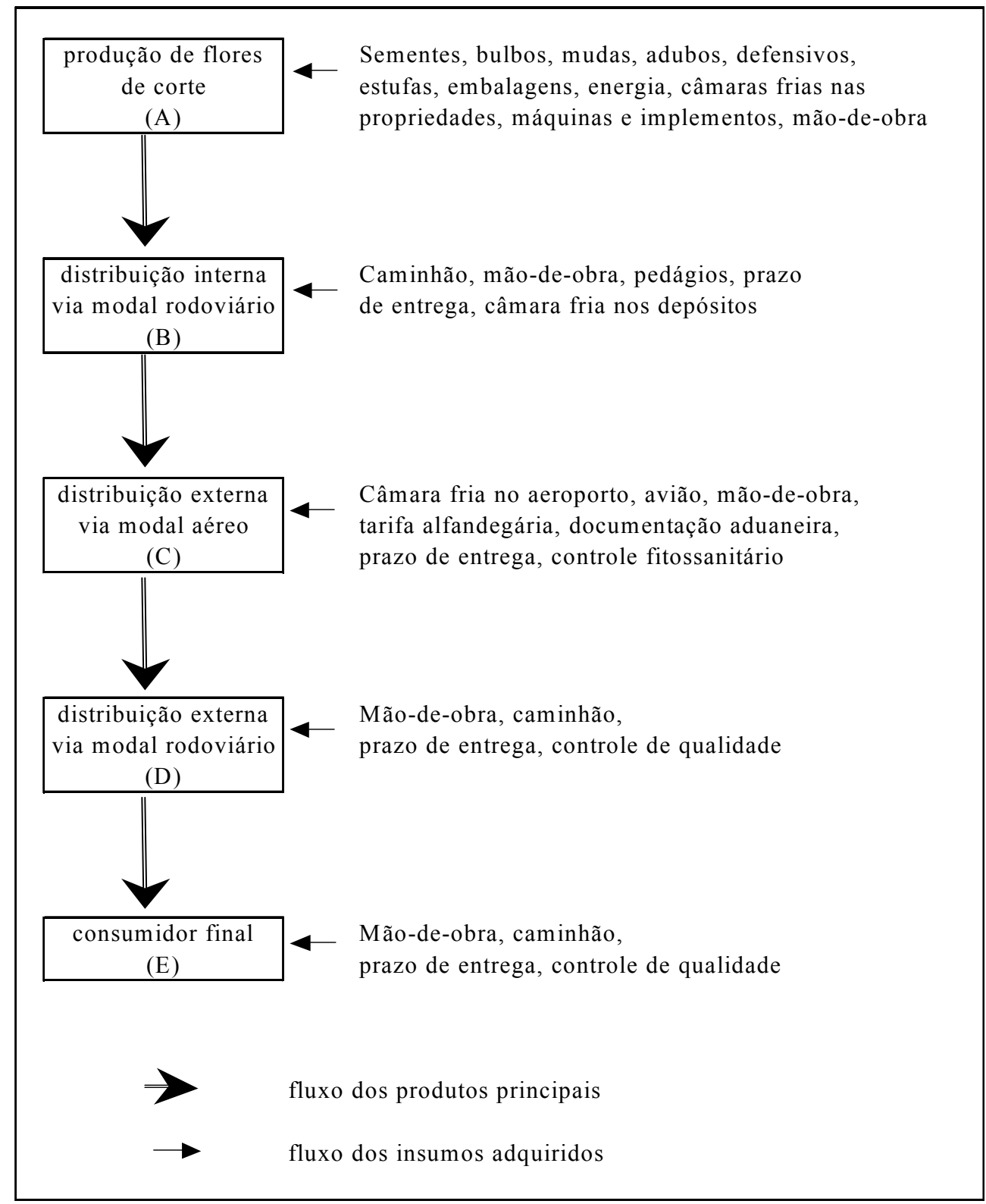

Figura 7 - Estrutura geral do modelo insumo-produto de processo proposto para a exportação de flores de corte

Nesse modelo são considerados os fluxos principais das relações entre produtores, exportadores e distribuidores, pois a partir deles são gerados os produtos principais da cadeia. Os demais componentes da cadeia, tais como despachante aduaneiro, transportadora, companhias aéreas são considerados como parte de fluxos secundários, provenientes desses agentes principais. Desta forma, esses agentes 
secundários foram inseridos nos custos dos agentes principais no processo de exportação.

Dentre os principais componentes que fazem parte do modelo, pode-se relacionar:

a) natureza da demanda dos produtos gerados na cadeia, definida a partir da classificação proposta por Fisher (1997);

b) produtos principais, selecionados a partir das principais flores temperadas e tropicais exportadas pelo Brasil, de acordo com a disponibilidade de informações. Para isso, foram consultadas as instituições que representam o setor, tais como, IBRAFLOR, Câmaras Setoriais, Associações e cooperativas de produtores, Comitês e literatura, para obter informações mais detalhadas sobre os produtores que exportam flores e quais os produtos direcionados para o exterior;

c) agentes da cadeia, especificados a partir da escolha dos principais produtos exportados atualmente no Brasil. No caso de lírios, por exemplo, de acordo com Caixeta-Filho, Swaay-Neto e Wagemaker (2002), há compra de bulbos importados de outros países por meio de transporte marítimo, para que se inicie o processo de produção de flores. Há, também, a possibilidade de produção de bulbos de gladíolos no Brasil, conforme Caixeta-Filho, Swaay-Neto e Lopes (2000). Em geral, esse ciclo produtivo é de dois anos e contempla insumos e agentes específicos na cadeia;

d) processos analisados, detalhados a partir da estrutura geral do modelo apresentada na Figura 7. Deve-se acrescentar que para cada um dos processos da cadeia há a descrição dos insumos utilizados. Nesse modelo não se considerou a importação de produtos.

\section{(2) Formulação de questionários}

A partir da primeira etapa, as informações necessárias sobre os diversos agentes da cadeia foram especificadas através da formulação de questionários, para que fossem obtidos todos os dados do modelo. A princípio, esses dados basearam-se nos elementos das matrizes relacionadas na Figura 5, ou seja, informações técnicas sobre os processos 
de produção e contábeis das empresas, tais como a receita e custo dos principais produtos. O Anexo A apresenta os questionários utilizados na pesquisa.

\section{(3) Implementação do modelo matemático}

A partir da definição das etapas anteriores, o modelo matemático foi implementado computacionalmente, com a utilização do software SAS para Windows, versão 8.2 .

\section{(4) Análise do modelo}

$\mathrm{Na}$ análise do modelo foram extraídos resultados provenientes de cada um dos processos de produção, de $\mathrm{A}$ a $\mathrm{D}$, com o intuito de medir o desempenho da cadeia de suprimentos e de cada um de seus processos. Como complemento foram avaliados os impactos na cadeia, como um todo ou em determinados processos, a partir de mudanças exógenas ao modelo, descritas no próximo capítulo, por meio da composição de novos cenários logísticos.

\subsubsection{Estrutura matemática do modelo}

O Quadro 3 apresenta os componentes do modelo para a exportação de flores de corte. Pelo que se observa, a sua estrutura inicial foi totalmente redimensionada e todos os elementos de suas matrizes foram adaptados à exportação de flores de corte, a partir de análise bastante detalhada de parâmetros teóricos e práticos para que pudessem ser inseridos no modelo. A matriz de insumos adquiridos foi dividida em insumos adquiridos para produção (I) e insumos logísticos (L), para avaliar o desempenho logístico de cada um dos processos; e a matriz de componentes produzidos durante o processo de produção e resíduos foi reestruturada para captar o produto logístico através da eficiência do ciclo do pedido (W). Por exemplo, a exportação de determinada flor é

dividida em processos. Em cada um deles são gerados produtos principais, flores de corte, denominados $Z_{I J}(I, J$ correspondem aos produtos obtidos dos processos $A, B, C$ e $D$ ). Há também o produto logístico, denominado PLG $i$ (neste caso $i=1$ ), que mede a 
eficiência do ciclo do pedido dos produtos principais, adicionando ou subtraindo valor monetário no produto final de cada processo. Em cada processo esses produtos sofrem alterações, em função dos insumos adquiridos para a sua produção, denominados IPRi, com $i=1,2, \ldots, 20$; dos insumos logísticos, denominados ILGi, com $i=1,2, \ldots, 15$; dos insumos primários, denominados IPM $i, \operatorname{com} i=1,2, \ldots, 6$, cada um deles utilizado especificamente em cada etapa. Há alguns itens que são medidos em quantidade, como é o caso dos produtos principais e de alguns insumos adquiridos para a produção, a fim de obter melhor caracterização da cadeia. Nesses casos é necessária, também, a inclusão de seus preços unitários para compará-los aos demais itens por meio de seu valor monetário.

\begin{tabular}{|c|c|c|c|c|c|c|}
\hline \multirow[b]{3}{*}{ Processos } & \multirow[b]{3}{*}{$\begin{array}{l}\text { Códi- } \\
\text { gos }\end{array}$} & \multirow{3}{*}{$\begin{array}{l}\text { Unida- } \\
\text { des } \\
\text { (por } \\
\text { ano) }\end{array}$} & \multicolumn{4}{|c|}{ Processos } \\
\hline & & & A & $\mathrm{B}$ & $\mathrm{C}$ & $\mathrm{D}$ \\
\hline & & & $\begin{array}{l}\text { Produ- } \\
\text { ção }\end{array}$ & $\begin{array}{c}\text { Dist. } \\
\text { Interna } \\
\text { rodoviário }\end{array}$ & $\begin{array}{c}\text { Dist. } \\
\text { Externa } \\
\text { aéreo }\end{array}$ & $\begin{array}{c}\text { Dist. } \\
\text { Externa } \\
\text { rodoviário }\end{array}$ \\
\hline \multicolumn{7}{|l|}{ Produtos } \\
\hline Produção & $\mathrm{A}$ & Unidade & $Z_{A A}$ & $\overline{Z_{A B}}$ & $Z_{A C}$ & $\overline{Z_{A D}}$ \\
\hline $\begin{array}{l}\text { Distribuição interna/modal } \\
\text { rodoviário }\end{array}$ & $\mathrm{B}$ & Unidade & $Z_{B A}$ & $Z_{B B}$ & $Z_{B C}$ & $Z_{B D}$ \\
\hline $\begin{array}{l}\text { Distribuição externa/modal } \\
\text { aéreo }\end{array}$ & $\mathrm{C}$ & Unidade & $\bar{Z} Z_{C A}$ & $\overline{Z_{C B}}$ & $\overline{Z_{C C}}$ & $Z_{C D}$ \\
\hline $\begin{array}{l}\text { Distribuição externa/modal } \\
\text { rodoviário }\end{array}$ & $\mathrm{D}$ & Unidade & $Z_{D A}$ & $Z_{D B}$ & $Z_{B C}$ & $Z_{D D}$ \\
\hline \multicolumn{7}{|c|}{ Insumos adquiridos para produção } \\
\hline Bulbos & IPR1 & Unidade & $I_{1 A}$ & $I_{I B}$ & $I_{l C}$ & $I_{1 D}$ \\
\hline Sementes & IPR2 & Unidade & $I_{2 A}$ & $I_{2 B}$ & $I_{2 C}$ & $I_{2 D}$ \\
\hline Mudas & IPR3 & Unidade & $I_{3 A}$ & $I_{3 B}$ & $I_{3 C}$ & $I_{3 D}$ \\
\hline Substrato & IPR4 & $\mathrm{m}^{3}$ & $I_{4 A}$ & $I_{4 B}$ & $I_{4 C}$ & $I_{4 D}$ \\
\hline Defensivos & IPR5 & $\mathrm{Kg}$ & $I_{5 A}$ & $I_{5 B}$ & $I_{5 C}$ & $I_{5 D}$ \\
\hline Fertilizantes & IPR6 & $\mathrm{Kg}$ & $I_{6 A}$ & $I_{6 B}$ & $I_{6 C}$ & $I_{6 D}$ \\
\hline Caixas plásticas & IPR7 & Unidade & $I_{7 \mathrm{~A}}$ & $I_{7 B}$ & $I_{7 \mathrm{C}}$ & $I_{7 D}$ \\
\hline Vasos & IPR8 & Unidade & $I_{8 A}$ & $I_{8 B}$ & $I_{8 \mathrm{C}}$ & $I_{8 D}$ \\
\hline Equipamento de escritório & IPR9 & $\mathrm{R} \$$ & $I_{9 A}$ & $I_{9 B}$ & $I_{9 C}$ & $I_{9 D}$ \\
\hline Telefone+comunicação & IPR10 & $\mathrm{R} \$$ & $I_{10 A}$ & $I_{10 B}$ & $I_{10 \mathrm{C}}$ & $I_{10 D}$ \\
\hline Seguro veículos & IPR11 & $\mathrm{R} \$$ & $I_{11 \mathrm{~A}}$ & $I_{11 B}$ & $I_{11 C}$ & $I_{11 D}$ \\
\hline Infraestrutura & IPR12 & $\mathrm{R} \$$ & $I_{12 \mathrm{~A}}$ & $I_{12 B}$ & $I_{12 \mathrm{C}}$ & $I_{12 D}$ \\
\hline Estrutura (estufa,viveiro) & IPR13 & $\mathrm{R} \$$ & $I_{13 \mathrm{~A}}$ & $I_{13 B}$ & $I_{13 \mathrm{C}}$ & $I_{13 D}$ \\
\hline Plástico ${ }^{1}$ & IPR14 & $\mathrm{R} \$$ & $I_{14 A}$ & $I_{14 B}$ & $I_{14 C}$ & $I_{14 D}$ \\
\hline
\end{tabular}

Quadro 3 - Componentes do modelo insumo-produto de processo para a cadeia de suprimentos de flores de corte 


\begin{tabular}{|c|c|c|c|c|c|c|}
\hline Sombrite $^{1}$ & IPR15 & $\mathrm{R} \$$ & $I_{15 \mathrm{~A}}$ & $I_{15 B}$ & $I_{15 \mathrm{C}}$ & $I_{15 D}$ \\
\hline Irrigação $^{1}$ & IPR16 & $\mathrm{R} \$$ & $I_{16 \mathrm{~A}}$ & $I_{16 B}$ & $I_{16 C}$ & $I_{16 D}$ \\
\hline $\begin{array}{l}\text { Máquinas, implementos e } \\
\text { outros veículos }\end{array}$ & IPR17 & $\mathrm{R} \$$ & $I_{17 \mathrm{~A}}$ & $I_{17 B}$ & $I_{17 C}$ & $I_{17 D}$ \\
\hline Eletricidade $^{2}$ & IPR18 & $\mathrm{R} \$$ & $I_{18 \mathrm{~A}}$ & $I_{18 B}$ & $I_{18 \mathrm{C}}$ & $I_{18 D}$ \\
\hline Combustível & IPR19 & $\mathrm{R} \$$ & $I_{19 \mathrm{~A}}$ & $I_{19 B}$ & $I_{19 \mathrm{C}}$ & $I_{19 D}$ \\
\hline Reservatório de água & IPR20 & $\mathrm{R} \$$ & $I_{20 A}$ & $I_{20 B}$ & $I_{20 \mathrm{C}}$ & $I_{20 D}$ \\
\hline \multicolumn{7}{|l|}{ Insumos logísticos } \\
\hline Frete rodoviário & ILG1 & $\mathrm{R} \$$ & $L_{1 A}$ & $L_{1 B}$ & $L_{1 C}$ & $L_{I D}$ \\
\hline $\begin{array}{l}\text { Energia para estocagem de } \\
\text { bulbos, sementes e mudas }\end{array}$ & ILG2 & $\mathrm{R} \$$ & $L_{2 A}$ & $L_{2 B}$ & $L_{2 C}$ & $L_{2 D}$ \\
\hline $\begin{array}{l}\text { Energia para estocagem do } \\
\text { produto final (flor de corte) }\end{array}$ & ILG3 & $\mathrm{R} \$$ & $L_{3 A}$ & $L_{3 B}$ & $L_{3 C}$ & $L_{3 D}$ \\
\hline Câmara fria ${ }^{1}$ & ILG4 & $\mathrm{R} \$$ & $L_{4 A}$ & $L_{4 B}$ & $L_{4 C}$ & $L_{4 D}$ \\
\hline Energia para pré-cooling & ILG5 & $\mathrm{R} \$$ & $L_{5 A}$ & $L_{5 B}$ & $L_{5 C}$ & $L_{5 D}$ \\
\hline Pré-cooling ${ }^{1}$ & ILG6 & $\mathrm{R} \$$ & $L_{6 A}$ & $L_{6 B}$ & $L_{6 C}$ & $L_{6 D}$ \\
\hline $\begin{array}{l}\text { Mão-de-obra para } \\
\text { paletização }\end{array}$ & ILG7 & $\mathrm{R} \$$ & $L_{7 A}$ & $L_{7 B}$ & $L_{7 C}$ & $L_{7 D}$ \\
\hline Paletização $^{1}$ & ILG8 & $\mathrm{R} \$$ & $L_{8 A}$ & $L_{8 B}$ & $L_{8 C}$ & $L_{8 D}$ \\
\hline $\begin{array}{l}\text { Custo da temperatura do } \\
\text { veículo }\end{array}$ & ILG9 & $\mathrm{R} \$$ & $L_{9 A}$ & $L_{9 B}$ & $L_{9 C}$ & $L_{9 D}$ \\
\hline Embalagem para exportação & ILG10 & $\mathrm{R} \$$ & $L_{10 A}$ & $L_{10 B}$ & $L_{10 \mathrm{C}}$ & $L_{10 D}$ \\
\hline Reserva de espaço aéreo & ILG11 & $\mathrm{R} \$$ & $L_{11 \mathrm{~A}}$ & $L_{11 B}$ & $L_{11 C}$ & $L_{11 D}$ \\
\hline Desembaraço aduaneiro & ILG12 & $\mathrm{R} \$$ & $L_{12 A}$ & $L_{12 B}$ & $L_{12 C}$ & $L_{12 D}$ \\
\hline $\begin{array}{l}\text { Frete aéreo (tarifa } \\
\text { alfandegária) }\end{array}$ & ILG13 & $\mathrm{Kg}$ & $L_{13 A}$ & $L_{13 B}$ & $L_{13 \mathrm{C}}$ & $L_{13 D}$ \\
\hline Sistema de informação & ILG14 & $\mathrm{R} \$$ & $L_{14 A}$ & $L_{14 B}$ & $L_{14 C}$ & $L_{14 D}$ \\
\hline Taxas de comercialização & ILG15 & $\mathrm{R} \$$ & $L_{15 A}$ & $L_{15 B}$ & $L_{15 \mathrm{C}}$ & $L_{15 D}$ \\
\hline \multicolumn{7}{|l|}{ Produtos logísticos } \\
\hline Eficiência do ciclo do pedido & PLG1 & $\mathrm{R} \$$ & $V_{1 A}$ & $V_{l B}$ & $V_{I C}$ & $V_{I D}$ \\
\hline \multicolumn{7}{|c|}{ Insumos primários } \\
\hline $\begin{array}{l}\text { Investimento de capital do } \\
\text { processo }\end{array}$ & IPM1 & $\mathrm{R} \$$ & $W_{1 A}$ & $W_{l B}$ & $W_{I C}$ & $W_{I D}$ \\
\hline Avulsos (inclui horas extras) & IPM2 & $\mathrm{R} \$$ & $W_{2 A}$ & $W_{2 B}$ & $W_{2 C}$ & $W_{2 D}$ \\
\hline Administrativo & IPM3 & $\mathrm{R} \$$ & $W_{3 A}$ & $W_{3 B}$ & $W_{3 C}$ & $W_{3 D}$ \\
\hline Operacional $^{3}$ & IPM4 & $\mathrm{R} \$$ & $W_{4 A}$ & $W_{4 B}$ & $W_{4 C}$ & $W_{4 D}$ \\
\hline Terra/imóvel & IPM5 & $\mathrm{R} \$$ & $W_{5 A}$ & $W_{5 B}$ & $W_{5 C}$ & $W_{5 D}$ \\
\hline \multicolumn{7}{|c|}{ Produto bruto dos principais produtos } \\
\hline Vetor X & PBX1 & Unidade & $X_{A}$ & $X_{B}$ & $X_{C}$ & $X_{D}$ \\
\hline
\end{tabular}

Quadro 3 - Componentes do modelo insumo-produto de processo para a cadeia de suprimentos de flores de corte

${ }^{1}$ Nesse item considerou-se as taxas de manutenção, juros e depreciação anuais

${ }^{2}$ Do item eletricidade foi extraído o gasto com energia para o estoque de bulbos, sementes e mudas (ILG3) e de flores de corte (ILG5)

${ }^{3}$ Do item operacional extraiu-se o gasto com a mão-de-obra para paletização (ILG7) 
As equações (11) a (14) apresentam a adaptação das matrizes $\mathbf{I}, \mathbf{L}, \mathbf{W}$ e $\mathbf{V}$.

$$
\mathbf{X}^{\mathbf{i}}=\mathbf{B X}=\mathbf{I T}
$$

onde:

$\mathbf{X}^{\mathbf{i}}$ é o vetor do total de consumo de cada um dos insumos adquiridos para produção $k$, para $k=1,2, \ldots, i$;

$\mathbf{I}=\left[I_{k j}\right]$ é a matriz de consumo de insumos adquiridos para produção $k$ no processo $j$;

$\mathbf{B}=\left[B_{k j}\right]$ é a matriz de coeficientes diretos de insumo-produto para insumos adquiridos para produção $k$ no processo $j$.

$$
\mathbf{X}^{\mathbf{l}}=\mathbf{C X}=\mathbf{L T}
$$

onde:

$\mathbf{X}^{1}$ é o vetor do total de consumo de cada um dos insumos logísticos $k$, para $l=1,2, \ldots, l$; $\mathbf{L}=\left[L_{k j}\right]$ é a matriz de consumo de insumos logísticos $k$ no processo $j$;

$\mathbf{C}=\left[C_{k j}\right]$ é a matriz de coeficientes diretos de insumo-produto para insumos adquiridos para produção $k$ no processo $j$.

$$
\mathbf{X}^{\mathbf{w}}=\mathbf{D X}=\mathbf{W T}
$$

onde:

$\mathbf{X}^{\mathbf{w}}$ é o vetor do total de produção de cada produto logístico $k$;

$\mathbf{W}=\left[W_{k j}\right]$ é a matriz de produção do produto logístico $k$ no processo $j$;

$\mathbf{D}=\left[D_{k j}\right]$ é a matriz de coeficientes diretos de insumo-produto para produto logístico $k$ no processo $j$.

$$
\mathbf{X}^{\mathbf{v}}=\mathbf{E X}=\mathbf{V T}
$$

onde:

$\mathbf{X}^{\mathbf{v}}$ é o vetor do total de consumo de cada insumo primário $k$; 
$\mathbf{V}=\left[V_{k j}\right]$ é a matriz de consumo de insumos primários $k$ no processo $j$;

$\mathbf{E}=\left[E_{k j}\right]$ é a matriz de coeficientes diretos de insumo-produto para insumos primários $k$ no processo $j$.

A partir das matrizes definidas anteriormente, pode-se calcular os custos, as receitas e os lucros de cada processo e da cadeia como um todo, conforme mostram as eq.(15) a (22).

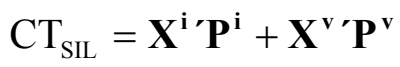

onde:

$C T_{S I L}$ é o custo total sem considerar o insumo logístico;

$\mathbf{P}^{\mathbf{i}}=\left[P_{k j}^{i}\right]$ é o vetor de preços dos insumos adquiridos para produção $k$ no processo $j$;

$\mathbf{P}^{\mathbf{v}}=\left[P_{k j}^{v}\right]$ é o vetor de preços dos insumos primários $k$ no processo $j$.

$$
C T_{C I L}=\mathbf{X}^{\mathbf{m}{ }^{\prime}} \mathbf{P}^{\mathbf{m}}+\mathbf{X}^{\mathbf{v}} \mathbf{P}^{\mathbf{v}}+\mathbf{X}^{\mathrm{g}{ }^{\prime}} \mathbf{P}^{\mathrm{g}}
$$

onde:

$C T_{C I L}$ é o custo total considerando o insumo logístico;

$\mathbf{P}^{\mathbf{g}}=\left[P_{k j}^{g}\right]$ é o vetor de preços dos insumos logísticos $k$ no processo $j$.

$$
R T_{S P L}=\mathbf{X}^{\mathbf{z}} \mathbf{P}^{\mathbf{z}}
$$

onde:

$R T_{S P L}$ é a receita total sem considerar o produto logístico;

$\mathbf{P}^{\mathrm{z}}$ é o vetor de preços do produto principal $k$ no processo $j$.

$$
R T_{C P L}=\mathbf{X}^{\mathbf{z}{ }^{\prime}} \mathbf{P}^{\mathbf{z}}+\mathbf{X}^{\mathbf{w}} \mathbf{P}^{\mathbf{w}}
$$

onde: 
$R T_{C P L}$ é a receita total considerando o produto logístico;

$\mathbf{P}^{\mathbf{w}}$ é o vetor de preços do produto logístico $k$ no processo $j$.

$$
L T_{S I P L}=R T_{S P L}-C T_{S I L}
$$

onde:

$L T_{\text {SIPL }}$ é o lucro total sem considerar insumo e produto logísticos.

$$
L T_{C I L}=R T_{S P L}-C T_{C I L}
$$

onde:

$L T_{C I L}$ é o lucro total considerando o insumo logístico.

$$
L T_{C P L}=R T_{C P L}-C T_{S P L}=\mathbf{P}^{\mathbf{y}} \mathbf{Y}+\mathbf{P}^{\mathbf{w}} \mathbf{X}^{\mathbf{w}}-\mathbf{P}^{\mathbf{m}} \mathbf{X}^{\mathbf{m}}-\mathbf{P}^{\mathbf{g}} \mathbf{X}^{\mathbf{g}}
$$

onde:

$L T_{C P L}$ é o lucro total considerando o produto logístico.

$$
L T_{C I P L}=R T_{C P L}-C T_{C I L}=\mathbf{P}^{\mathbf{y}} \mathbf{Y}+\mathbf{P}^{\mathbf{w}} \mathbf{X}^{\mathbf{w}}-\mathbf{P}^{\mathbf{m}} \mathbf{X}^{\mathbf{m}}-\mathbf{P}^{\mathbf{g}} \mathbf{X}^{\mathbf{g}}-\mathbf{P}^{\mathbf{v}} \mathbf{X}^{\mathbf{v}}
$$

onde:

$L T_{C I P L}$ é o lucro total considerando insumo e produto logísticos.

A partir dos componentes do lucro total $L T_{C I P L}$, por exemplo, pode-se obter os lucros unitários bruto e final de cada processo, conforme mostram as eq. (23) e (24). 


$$
\mathbf{L}_{\mathbf{b r}}=\left(\begin{array}{lllll}
P^{z} & P^{m} & P^{g} & P^{w} & P^{v}
\end{array}\right)\left(\begin{array}{c}
A \\
B \\
C \\
D \\
E
\end{array}\right)
$$

onde:

$\mathbf{L}_{\text {br }}$ é o vetor do lucro unitário da produção bruta dos principais produtos de cada processo $j$.

$$
\mathbf{L}_{\text {liq }}=\left(\begin{array}{lllll}
P^{z} & P^{m} & P^{g} & P^{w} & P^{v}
\end{array}\right)\left(\begin{array}{c}
A \\
B A^{-1} \\
C A^{-1} \\
D \\
E
\end{array}\right)
$$

onde:

$\mathbf{L}_{\text {liq }}$ é o vetor do lucro unitário da produção final dos principais produtos de cada processo $j$.

Os vetores de lucro unitário da produção bruta e final serão idênticos se a matriz A for unitária. Isso ocorrerá se o produto resultante de cada processo não for utilizado na etapa seguinte.

A seguir serão apresentados e discutidos os desdobramentos do modelo proposto para este estudo, a fim de analisar os impactos dos processos logísticos no desempenho da cadeia de flores de corte. 


\section{RESULTADOS E DISCUSSÃO}

No entendimento da cadeia de flores de corte para exportação, a natureza da demanda dos produtos nela gerados é um dos aspectos que merece destaque. Para isso, alguns agentes da cadeia, ligados aos processos de produção e distribuição interna rodoviária, foram questionados para que se obtivessem alguns parâmetros sobre as características do produto, conforme estruturado no questionário A (vide Anexo A): (1) sua função (inovador ou funcional); (2) margem de lucro; (3) ciclo de vida do produto; (4) margem de contribuição; (5) variedade do produto; (6) margem média de erro na previsão da produção; (7) taxa média de quebra de estoque; (8) prazo de entrega para produtos por pedido; (9) tipo de demanda (previsível ou imprevisível); (10) tipo de cadeia de suprimentos (responsiva ou eficiente). A Figura 8 apresenta de forma resumida os principais resultados observados. 


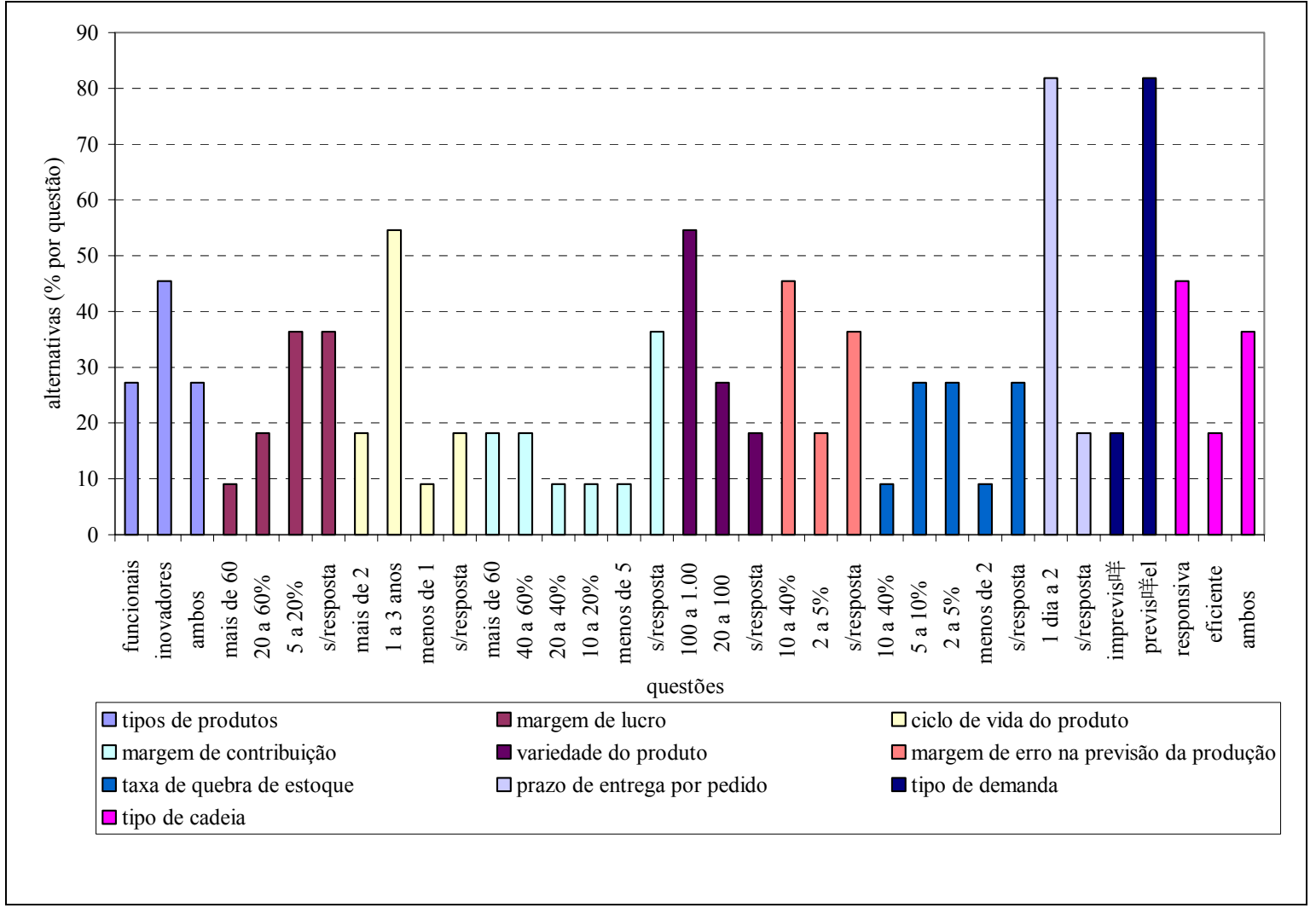

Figura 8 - Características da demanda de flores de corte destinadas à exportação

Ao se comparar esses resultados com os expostos por Fisher (1997), contidos no Quadro 1 apresentado anteriormente, não é possível classificar o produto flor de corte como funcional ou como inovador, uma vez que possui algumas características presentes em ambos os conceitos. No caso de margem de contribuição, entre 20 e $60 \%$, e número mais alto de variedades, de 20 a 100 por categoria, prazos de entrega menores, de um dia a duas semanas, e ciclo de vida do produto de um a três anos, está de acordo com produtos inovadores. Em relação à margem média de erro na previsão da produção, até $40 \%$, e taxa média de quebra de estoque, até $10 \%$, e demanda previsível, está mais próximo de produtos funcionais. Esse tipo de demanda está relacionado ao conhecimento de períodos de entressafra dos concorrentes e das datas comemorativas dos países destino. No caso dos EUA, essas datas distribuem-se ao longo do ano ${ }^{5}$. De

\footnotetext{
${ }^{5} \mathrm{~A}$ descrição dessas datas está disponível em http://www.flowercouncil.org/int/Events/ Specialdays2004/2004United_States_of_America.asp
} 
acordo com Fails e Carlson (1998), a época do ano influencia as vendas nos supermercados. Há maior concentração nos feriados, principalmente Dia das Mães, Dia dos Namorados, Páscoa e Natal.

Além disso, observa-se que há diferentes opiniões sobre o tipo de produto e de cadeia a que pertencem flores de corte para exportação, e que algumas questões não são respondidas pelos entrevistados. Isso pode indicar que não há ainda convergência de prioridades e estratégias nessa cadeia de suprimentos.

Outro ponto que deve ser considerado nessa análise é o fato de terem sido introduzidas nas exportações brasileiras, mais recentemente, flores de corte tropicais, além das temperadas. Isso tem motivado o setor a aumentar suas expectativas quanto ao crescimento das exportações desse produto, pois detém características bem distintas dos demais, sendo que os impactos de inovações tecnológicas nessas flores poderão ser mais facilmente visualizáveis, tornando a cadeia mais responsiva.

\subsection{Processos da cadeia de flores de corte para exportação}

O Quadro 4 apresenta os componentes do modelo, no qual estão descritos os processos (de A a E), os agentes e os insumos da cadeia de flores. Esse modelo pode ser utilizado tanto para a exportação de flores temperadas quanto tropicais. Considerou-se que são utilizados apenas dois modais: rodoviário, para transportar o produto dentro de cada país; aéreo, para transportar o produto entre os países exportador e importador, relacionado ao processo "Distribuição externa/modal aéreo". O processo "Distribuição interna/modal rodoviário" representa a distribuição por caminhão dentro do país exportador, no caso o Brasil; no processo "Distribuição externa/modal rodoviário" ocorre o transporte rodoviário dentro do país importador, como EUA e Holanda.

Na cadeia de flores de corte pode-se identificar os seguintes agentes, para cada um dos processos: produtores, cooperativas, transportadoras, exportadores, despachantes aduaneiros, representantes do Governo brasileiro (Receita Federal, Ministério da Agricultura, Infraero) e estrangeiro, importadores, distribuidores, atacadistas, varejistas e 
consumidores finais. Para compor este estudo, o processo de "Distribuição Final" (processo E) não foi considerado na análise.

\begin{tabular}{|l|c|c|l|}
\hline \multicolumn{1}{|c|}{ Processos } & Código & Agentes & \multicolumn{1}{|c|}{ Insumos } \\
\hline $\begin{array}{l}\text { Produção na } \\
\text { propriedade } \\
\text { rural }\end{array}$ & A & $\begin{array}{c}\text { Produtores, fornecedores de } \\
\text { insumos }\end{array}$ & $\begin{array}{l}\text { Sementes, bulbos, mudas, } \\
\text { adubos, defensivos, estufas, } \\
\text { embalagens, energia, câmaras } \\
\text { frias nas propriedades, } \\
\text { máquinas e implementos, } \\
\text { mão-de-obra }\end{array}$ \\
\hline $\begin{array}{l}\text { Distribuição } \\
\text { interna/modal } \\
\text { rodoviário }\end{array}$ & B & $\begin{array}{c}\text { Cooperativas, } \\
\text { transportadoras, } \\
\text { exportadores }\end{array}$ & $\begin{array}{l}\text { Caminhão, mão-de-obra, } \\
\text { pedágios, prazo de entrega, } \\
\text { câmara fria nos depósitos }\end{array}$ \\
\hline $\begin{array}{l}\text { Distribuição } \\
\text { externa/modal } \\
\text { aéreo }\end{array}$ & C & $\begin{array}{c}\text { Exportadores, agentes de } \\
\text { carga, despachantes } \\
\text { aduaneiros no Brasil e } \\
\text { exterior, Receita Federal, } \\
\text { Infraero, Ministério da } \\
\text { Agricultura, importadores }\end{array}$ & $\begin{array}{l}\text { Câmara fria no aeroporto, } \\
\text { avião, mão-de-obra, frete } \\
\text { aéreo, documentação } \\
\text { aduaneira, prazo de entrega, } \\
\text { controle fitossanitário }\end{array}$ \\
\hline $\begin{array}{l}\text { Distribuição } \\
\text { externa/modal } \\
\text { rodoviário }\end{array}$ & D & $\begin{array}{l}\text { Transportadoras no } \\
\text { exterior, importadores }\end{array}$ & $\begin{array}{l}\text { Mão-de-obra, caminhão, } \\
\text { prazo de entrega, controle de } \\
\text { qualidade }\end{array}$ \\
\hline $\begin{array}{l}\text { Distribuição } \\
\text { final }\end{array}$ & E & $\begin{array}{c}\text { Importador, distribuidor, } \\
\text { varejista, consumidor final }\end{array}$ & $\begin{array}{l}\text { Mão-de-obra, caminhão, } \\
\text { prazo de entrega, controle de } \\
\text { qualidade }\end{array}$ \\
\hline
\end{tabular}

Quadro 4 - Identificação dos agentes pertencentes a cada um dos processos da cadeia

Dentro da cadeia, as cooperativas possuem um papel relevante em relação aos demais agentes, uma vez que ao atuarem como corretores (brokers) facilitam a intermediação dos negócios e efetivação das vendas junto aos produtores e, também, perante os exportadores, se for necessário. Os brokers podem assumir também responsabilidade sobre o armazenamento e distribuição do produto ou contratar operadores logísticos para executar essas atividades.

Considerou-se que em cada um dos processos foram gerados novos produtos principais, a partir da utilização dos anteriores. Por falta de eficiência em cada um dos 
processos, ocorreram perdas, que foram contabilizadas nos produtos e insumos logísticos.

Em cada um dos processos estão inseridos três tipos de insumos: adquiridos, tanto para produção quanto para exportação; logísticos; primários, nos quais foram considerados, basicamente, terra, capital e trabalho, conforme estruturado no questionário B (vide Anexo A).

A seguir estão relacionadas as principais características de cada um dos processos:

(A) Processo de produção na propriedade rural

No processo de produção na propriedade foram incluídos os gastos anuais do produtor, tais como bulbos, sementes, mudas, defensivos químicos, fertilizantes, estufas, embalagens, câmara fria, mão-de-obra e impostos. Podem existir relações com fornecedores de insumos de outros países, no caso de compra de sementes, bulbos ou mudas importadas, sujeitas ao pagamento de royalties pela utilização desse material básico.

Alguns insumos, como defensivos, fertilizantes e substrato, foram medidos em peso ou volume $\left(\mathrm{kg}\right.$ ou $\mathrm{m}^{3}$ ou litro) e tiveram coletados seus preços unitários. Já os demais foram expressos em reais ou unidades por ano, para facilitar o entendimento dos dados.

Os custos fixos utilizados no modelo, basicamente, relacionam-se a instalações, equipamentos, máquinas, veículos, sendo que o valor considerado no modelo foi calculado com base na soma dos custos de manutenção, juros e depreciação de cada item. Todos os custos foram calculados ou estimados visando apenas os produtos exportados pelos produtores.

Em termos de investimento do capital do processo, considerou-se que nas situações de déficit logístico são gastos em torno de $10 \%$ da receita total do produto para melhoria na preparação do produto para exportação, em função de viagens técnicas internacionais, introdução de novas variedades e embalagens novas. Nos demais processos, descritos a seguir, esse investimento foi nulo, por considerar que a exportação 
desse produto ainda é incipiente e não representa a atividade principal para os agentes de cada uma das etapas seguintes à da produção. Ao supor superávit logístico, supôs-se que houve acréscimo nos investimentos em cada um dos processos: de $2 \%$ na produção e de $1 \%$ nos restantes, com o intuito de atingir melhor eficiência e eficácia em cada uma das etapas.

$\mathrm{Na}$ análise da cadeia de flores de corte foram levados em conta os casos de flores distintas, lírio e gérbera. A Tabela 2 mostra a alocação dos custos médios operacionais e de investimento de quatro produtores brasileiros, sendo um deles de bulbos de Amaryllis e três de flores de corte.

Tabela 2. Comparação de custos operacionais e de investimento, em termos relativos, na produção de bulbos e de flores de corte

\begin{tabular}{|c|c|c|c|c|}
\hline \multicolumn{5}{|c|}{ Produção no Brasil } \\
\hline Itens & $\begin{array}{l}\text { Produtor } \\
\text { de bulbos } \\
\text { Amaryllis }\end{array}$ & $\begin{array}{c}\text { Produtor } \\
\text { da flor lírio }\end{array}$ & $\begin{array}{l}\text { Produtor da } \\
\text { flor gérbera } 1\end{array}$ & $\begin{array}{c}\text { Produtor da } \\
\text { flor gérbera } 2\end{array}$ \\
\hline Custos operacionais & \multicolumn{4}{|c|}{ (em porcentagem) } \\
\hline Defensivos químicos & 6,27 & 10,39 & 2,42 & 3,88 \\
\hline Fertilizantes & 9,73 & 7,76 & 86,88 & 6,07 \\
\hline Eletricidade & 7,14 & 0,93 & 1,24 & 10,19 \\
\hline Combustível & 9,47 & 0,47 & 1,12 & 1,46 \\
\hline Salários & 61,98 & 16,35 & 6,52 & 73,87 \\
\hline Frete & 0,00 & 57,92 & 0,00 & 0,00 \\
\hline Depreciação & 5,41 & 6,18 & 1,83 & 4,53 \\
\hline Total & 100,00 & 100,00 & 100,00 & 100,00 \\
\hline \multicolumn{5}{|l|}{ Custos de investimento } \\
\hline Terra, imóvel & 5,14 & 1,91 & 4,63 & 0,00 \\
\hline Infraestrutura & 10,79 & 0,77 & 14,85 & 7,80 \\
\hline Estrutura (estufa, viveiro) & 46,25 & 0,73 & 31,85 & 10,53 \\
\hline Sistema de irrigação & 6,47 & 0,76 & 2,38 & 14,70 \\
\hline Câmara fria & 0,00 & 3,40 & 0,00 & 27,22 \\
\hline Máquinas e outros veículos & 29,29 & 3,26 & 1,46 & 6,17 \\
\hline Equipamentos de escritório & 2,06 & 0,40 & 1,48 & 1,81 \\
\hline Material de propagação & 0,00 & 88,76 & 43,36 & 31,76 \\
\hline Total & 100,00 & 100,00 & 100,00 & 100,00 \\
\hline
\end{tabular}


Em relação à produção de bulbos nota-se que o custo de investimento mais elevado diz respeito às estufas e viveiros, sendo que a maioria dos custos operacionais está relacionada à mão-de-obra. Em função das características específicas de cada propriedade, esses custos passam a ter importância relativa menor que o frete, no caso do produtor de lírios, e que o fertilizante, no caso do produtor de gérbera 1 . No caso do lírio o material de propagação é o item mais relevante em termos de investimento, com maiores gastos com frete quando comparado aos demais, provavelmente devido à importação mais freqüente desse item. Isso se justifica pela necessidade do produtor em produzir flores provenientes de variedades mais novas e adequadas ao mercado interno ou externo nem sempre cultivadas no Brasil. O produtor de gérbera 1 possui menor área e produção mais recente quando comparado aos demais e possui uso mais intensivo de fertilizantes.

(B) Processo de distribuição interna/ modal rodoviário (dentro do país exportador)

Neste processo estão inseridas as relações entre produtores, cooperativas e exportadores para captar a distribuição das flores de corte da propriedade rural até a central de distribuição, que pode ser a cooperativa ou o depósito do exportador. Há casos em que atuam os três agentes, porém há também relações diretas entre produtores e exportadores. Em geral, nessa fase o produtor é responsável pelo transporte do produto até a central de distribuição. A cooperativa ou o exportador coordena armazenamento, paletização, pré-cooling e transporte até o aeroporto. As despesas com a distribuição interna até o aeroporto podem ser repassadas aos produtores, dependendo da negociação com o exportador.

Pode haver a contratação por parte dos produtores de empresa de courier que presta serviço porta-a-porta em nível internacional, como são os casos de DHL, Fedex e UPS, executando todo o despacho aduaneiro e reserva de carga, por intermédio de seus despachantes. Como não são especializadas em transporte de perecíveis, utilizam caminhões sem refrigeração para retirar mercadoria do produtor para o aeroporto. Há também parceria com determinadas empresas exportadoras para providenciar os demais 
documentos necessários para exportação da mercadoria. Todos esses serviços são cobrados do contratante.

(C) Processo de distribuição externa/modal aéreo

Nesta etapa estão incluídas as despesas com despacho aduaneiro e reserva de espaço aéreo, que são realizadas por despachante aduaneiro e agente de carga, respectivamente; fiscalização nos aeroportos, realizada pelo Ministério da Agricultura e Receita Federal; frete aéreo; comissão do exportador; perdas do produto, por ineficiência em cada processo.

Tanto a distribuição interna quanto externa dos produtos é realizada mediante rateio das despesas, proporcional ao volume embarcado pelos produtores, formando um consórcio logístico para otimizar os custos unitários com a exportação das flores de corte, que são reduzidos se maiores quantidades de flores de corte forem transportadas por embarque.

(D) Processo de distribuição externa/modal rodoviário (dentro do país importador)

Após o desembaraço da mercadoria no aeroporto do país importador, por exemplo, nos EUA, há duas alternativas para o importador transportar o produto para o depósito do distribuidor: transporte rodoviário próprio ou terceirizado.

(E) Processo de distribuição final

Nesta etapa há distribuição do produto para atacadistas e varejistas para que o produto chegue ao consumidor final com boa qualidade e durabilidade.

\subsection{Variáveis logísticas do modelo}

Dentre as variáveis logísticas identificadas, algumas delas foram consideradas em cálculos intermediários para obtenção dos insumos e produtos logísticos do modelo, de acordo com alguns critérios, descritos a seguir. O Quadro 5 apresenta a correspondência entre as variáveis logísticas intermediárias e as de entrada no modelo. 


\begin{tabular}{|c|c|c|c|}
\hline \multicolumn{2}{|c|}{ Variável intermediária } & \multicolumn{2}{|l|}{ Variável do modelo } \\
\hline Item & Unidade & Item & Unidade \\
\hline $\begin{array}{l}\text { Perda de bulbos, sementes } \\
\text { ou mudas e flores }\end{array}$ & $\%$ & Produto do processo $\mathrm{A}$ & Hastes \\
\hline $\begin{array}{l}\text { Estoque de bulbos, } \\
\text { sementes ou mudas }\end{array}$ & Dias/safra & $\begin{array}{l}\text { Energia com bulbos, } \\
\text { sementes ou mudas }\end{array}$ & $\mathrm{R} \$$ /ano \\
\hline Tempo de câmara fria & Horas/embarque & $\begin{array}{l}\text { custo de estocagem do } \\
\text { produto final }\end{array}$ & $\mathrm{R} \$$ /ano \\
\hline Frete rodoviário & $\mathrm{R} \$$ /embarque & $\begin{array}{l}\text { Custo de distribuição } \\
\text { rodoviária do produto final }\end{array}$ & $\mathrm{R} \$$ /ano \\
\hline Tempo de pré-cooling & Horas/embarque & Energia para pré-cooling & $\mathrm{R} \$$ /ano \\
\hline Temperatura do veículo & $\begin{array}{l}\text { Graus Celsius } \\
\left({ }^{\circ} \mathrm{C}\right)\end{array}$ & $\begin{array}{l}\text { Custo da temperatura do } \\
\text { veículo }\end{array}$ & $\mathrm{R} \$$ /ano \\
\hline Tempo de paletização & Horas/embarque & $\begin{array}{l}\text { Mão-de-obra para } \\
\text { paletização }\end{array}$ & $\mathrm{R} \$$ /ano \\
\hline Reserva de espaço aéreo & US\$/embarque & reserva de espaço aéreo & $\mathrm{R} \$$ /ano \\
\hline Desembaraço aduaneiro & $\begin{array}{l}\text { US\$/embarque } \\
\text { ou US\$/kg }\end{array}$ & Desembaraço aduaneiro & $\mathrm{R} \$$ /ano \\
\hline $\begin{array}{l}\text { Embalagem para } \\
\text { exportação }\end{array}$ & $\mathrm{R} \$$ /embalagem & $\begin{array}{l}\text { Embalagem para } \\
\text { exportação }\end{array}$ & $\mathrm{R} \$$ /ano \\
\hline Frete aéreo & $\mathrm{US} \$ / \mathrm{kg}$ & Frete aéreo & $\mathrm{R} \$$ /ano \\
\hline Sistema de informação & US\$/ano & Sistema de informação & $\mathrm{R} \$$ /ano \\
\hline Taxa de comercialização & $\begin{array}{l}\% \text { do valor de } \\
\text { venda ou US\$ } \\
\text { por venda }\end{array}$ & Taxa de comercialização & $\mathrm{R} \$$ /ano \\
\hline $\begin{array}{l}\text { Tempo efetivo do ciclo do } \\
\text { pedido }\end{array}$ & Dias/embarque & $\begin{array}{l}\text { Eficiência do ciclo do } \\
\text { pedido (R\$/ano) }\end{array}$ & $\mathrm{R} \$$ /ano \\
\hline
\end{tabular}

Quadro 5 - Relação entre as variáveis logísticas no cálculo intermediário e no modelo

A perda de bulbos/sementes/mudas/flores, em porcentagem, foi contabilizada no cálculo do total de hastes produzidas em cada um dos processos, gerando os produtos principais de cada etapa.

No item eletricidade estão inseridos gastos com câmara fria, computadores e irrigação. Considerou-se que $30 \%$ do custo total com eletricidade correspondem ao uso de câmara fria, sendo $12 \%$ para bulbos e sementes e $18 \%$ para flores de corte, levando em conta dois embarques semanais e dois dias de estoque por embarque nos 12 meses do ano. 
O estoque de bulbos/sementes/mudas, cuja unidade inicial é dias/safra, foi convertido para uso de energia para estoque de bulbos/sementes/mudas em câmara fria. Tal valor foi extraído do total gasto com eletricidade para o funcionamento da câmara fria, quando não informado diretamente, para captar a variável "energia com bulbos, sementes ou mudas", em R\$/ano.

Para os casos em que não foi possível obter gasto de energia da câmara fria de maneira direta, o tempo de câmara fria, em horas/embarque, foi convertido para tempo gasto em termos de energia. Tal valor foi extraído do total gasto com eletricidade para o funcionamento da câmara fria, denominando-se custo de estocagem do produto final para flores cortadas, com o uso ou não de câmara fria, em R\$ por ano.

O custo de distribuição rodoviária do produto final - flores de corte - em R\$ por ano, foi obtido a partir do gasto com transporte rodoviário, em função do frete cobrado por embarque.

O tempo de pré-cooling, em horas por embarque, foi convertido para energia de pré-cooling, em $\mathrm{R} \$$ por ano, a partir da extração desse item do valor cobrado para realizar essa operação nos processos de distribuição via modal rodoviário, se houver necessidade.

O custo da temperatura do veículo, em R\$ por ano, foi obtido com base na temperatura do veículo, em graus Celsius. Considerou-se perda de $1 \%$ no valor final do produto em cada etapa que não se observe temperatura adequada no veículo.

A paletização é uma etapa importante da exportação de flores de corte, pois exige cuidados no manuseio das caixas para não danificar as flores, com a utilização de cintas amarrando as embalagens. O tamanho do pallet é padrão, com a medida de 1,10 x 1,10 m. Para viabilizar essa comercialização há agentes da cadeia que indicam que o volume ideal é de no mínimo $500 \mathrm{~kg}$ (em torno de $30 \mathrm{full}$ ) por embarque. Ao se considerar o consórcio logístico, ou seja, o compartilhamento dos mesmos procedimentos de distribuição e de armazenamento por embarque com rateio das despesas em função do volume comercializado, recomenda-se em torno de $150 \mathrm{full}$ por embarque.

Para extrair o gasto com paletização, partiu-se do tempo com mão-de-obra para paletização, em horas por embarque. Este item foi calculado considerando que $10 \%$ das 
horas trabalhadas mensalmente são destinadas a essa atividade, para dois embarques semanais, ou seja, 16 horas por mês. O cálculo do total de 160 horas baseou-se em oito horas de trabalho por dia, cinco dias por semana e quatro semanas por mês.

$\mathrm{O}$ item reserva de espaço aéreo, em $\mathrm{R} \$$ por embarque, é proveniente da taxa cobrada para emissão do conhecimento aéreo (Airway Bill) no Brasil.

O desembaraço aduaneiro reúne todas as taxas pagas no despacho aduaneiro para embarcar o produto no Brasil e para desembarcá-lo nos EUA. Inclui despesas com o despachante aduaneiro nos dois países, pagas por embarque, com a emissão dos documentos de inspeção fitossanitária nos EUA, cobrada por embarque se essa atividade for executada fora do horário comercial, e com a obtenção de fatura comercial nos EUA, cujo valor é de US\$ 2.00 para nota fiscal de até US\$2,000.00 ou US\$25.00 para notas maiores que US\$2,000.00.

No caso da embalagem, em geral, esta é de papelão e os seus custos são pagos pelo produtor, porém, os dados nela impressos são relativos à marca do exportador. Se a exportação for feita por intermédio do Veiling Holambra para o Veiling na Holanda, não há essa restrição. Seu preço varia em função do tamanho da caixa, pois podem ser acondicionadas 75, 80 ou 100 hastes, de acordo com a variedade da flor e as necessidades do cliente. Há casos em que se exigem 50 a 60 hastes, no caso de gérbera, e 18, 24 a 30 hastes por caixa para o antúrio. As medidas dessas caixas seguem padrões internacionais, denominados full, calculados com base no volume cubado ou cubagem. Seu tamanho eqüivale a duas caixas de tabaco ou quatro caixas de antúrio, gérbera, lírio ou orquídea e pode ter várias dimensões, de acordo com o tipo de flor para obter a mínima cubagem por embalagem (por exemplo, $50 \mathrm{~cm}$ de largura x 22,5 cm de altura $\mathrm{x}$ $105 \mathrm{~cm}$ de comprimento ou $20 \times 26 \times 104 \mathrm{~cm}^{3}$ ). Para compor a caixa, os seguintes componentes opcionais, em função do tipo de flor, podem ser considerados: madeira na base, papelão em cima, fita, canudo para a haste, redinha e cone plástico.

A taxa de comercialização é composta por transações efetuadas de um processo para outro da cadeia de exportação. O produtor pode pagar todas essas taxas e o transporte até o aeroporto no país de origem ou destino, de acordo com o que for acordado com o exportador. Em geral, este agente paga o imposto sobre o valor da 
venda e, em alguns casos, também o Fundo de Assistência ao Trabalhador Rural (FUNRURAL) e repassa essa despesa para o produtor.

Deve-se considerar também que há duas formas de transação do produto, ou seja, pode ser vendido do produtor para exportador, com pagamento no ato ou venda consignada, na qual o exportador é contratado para vender o produto do produtor e o pagamento é feito após 60 dias, podendo ser Free on Board (FOB) ou Cost, Insurance and Freight (CIF), conforme acordo entre as partes.

A comissão do exportador contratado varia de acordo com o mercado de destino e da época do ano, podendo variar de 5 a $20 \%$ sobre o valor de venda do produtor. No país destino pode incidir taxa de importação do produto sobre o importador. No caso de exportação do Brasil para os EUA, as flores de corte possuem tarifa nula, exceto as rosas, para as quais há taxa de 6,80\%. Essa diferenciação ocorre em função de acordos bilaterais com o Brasil e essas informações estão incluídas no Sistema Geral de Preferências (SGP), de acordo com Harmonized (2004). Para o recebimento do pagamento no Brasil há uma taxa de despesa bancária por transação, para efetuar a transferência da venda do importador para o exportador, e de contribuição provisória sobre movimentação financeira (CPMF), cobrada sobre o depósito do exportador para a conta do produtor.

Além dos insumos logísticos, buscou-se captar a eficiência do ciclo do pedido, em $\mathrm{R} \$$ por ano, a partir do tempo efetivo de cada processo por embarque. Para isso foi estimado o tempo do pedido (lead time) total do ciclo logístico da exportação de flores de corte para cada um dos processos. Obtiveram-se assim acréscimos ou decréscimos no valor final do produto vendido em cada etapa, sinalizando para flores de melhor ou pior qualidade, respectivamente, o que estaria diretamente relacionado à eficiência de cada processo.

Considerou-se ainda que o tempo de duração de cada flor pode variar de 20 a 30 dias, ou seja: a colheita envolveria um período de um a três dias; mais dois dias para que a carga chegue ao aeroporto de Miami, podendo ficar em câmara fria por três dias. O transporte interno é realizado por caminhão até os atacadistas no prazo de aproximadamente dois dias, podendo ficar estocado na floricultura por três dias, para ou 
ser destinado ao consumidor final ou ser descartada. A partir desse último agente da cadeia, a durabilidade da flor pode variar em função da sua qualidade inicial e dos cuidados ao longo de todo o trajeto. Além desses parâmetros, foram também levadas em conta estimativas dos setores em geral, descritas em Lopez (2000), a partir de uma pesquisa realizada pela Fundação Getúlio Vargas de São Paulo, entre 1998 e 1999, com 177 empresas exportadoras, para adaptá-las para o setor de flores, conforme mostra a Tabela 3.

Tabela 3. Estimativas do lead time total do ciclo logístico do transporte aéreo para exportação de flores de corte, em dias

\begin{tabular}{|c|c|c|c|c|}
\hline \multirow[b]{2}{*}{ Atividade } & \multirow{2}{*}{$\begin{array}{c}\text { Código do } \\
\text { processo }\end{array}$} & \multicolumn{3}{|c|}{ lead time (dias) } \\
\hline & & Superávit & Ideal & Déficit \\
\hline 1. ciclo de produção do produtor ${ }^{1}$ & A & 86,00 & 90,00 & 90,00 \\
\hline 2. estoque de flores na propriedade ${ }^{1}$ & A & 1,00 & 1,00 & 2,00 \\
\hline 3. documentos do exportador brasileiro ${ }^{1}$ & B & 0,67 & 0,98 & 1,00 \\
\hline $\begin{array}{l}\text { 4. transporte local das instalações do } \\
\text { produtor para exportador }\end{array}$ & $B$ & 0.02 & 0.02 & 0.02 \\
\hline 5. estoque de flores no exportador & B & 0,00 & 0,00 & 0,00 \\
\hline $\begin{array}{l}\text { 6. transporte local, das instalações do } \\
\text { exportador até o terminal de embarque }\end{array}$ & B & 0,08 & 0,08 & 0,08 \\
\hline $\begin{array}{l}\text { 7. movimentação e armazenamento em áreas } \\
\text { alfandegadas no Brasil, até o início do } \\
\text { desembaraço aduaneiro de exportação }\end{array}$ & $\mathrm{C}$ & 0,08 & 0,083 & 0,17 \\
\hline 8. desembaraço aduaneiro de exportação & $\mathrm{C}$ & 0,50 & 0,50 & 0,50 \\
\hline 9. transporte internacional & $\mathrm{C}$ & 0,33 & 0,33 & 0,33 \\
\hline $\begin{array}{l}\text { 10. desembaraço aduaneiro no país do } \\
\text { importador }\end{array}$ & $\mathrm{C}$ & 0,17 & 0,17 & 0,17 \\
\hline $\begin{array}{l}\text { 11. transporte local, desde o terminal até as } \\
\text { instalações do importador }\end{array}$ & $\mathrm{D}$ & $\begin{array}{r}2,00 \\
90.85\end{array}$ & $\begin{array}{r}2,00 \\
95,17\end{array}$ & $\begin{array}{r}2,00 \\
96,27\end{array}$ \\
\hline 12. Total & & & & 96,27 \\
\hline
\end{tabular}

Fonte: adaptado de Lopez (2000)

${ }^{1}$ Itens cujos valores foram alterados, podendo gerar superávit ou déficit logístico nesses processos 
A partir desses dados, essas atividades foram agregadas nos quatro processos analisados (A, B, C e D), para então se calcular os percentuais de superávit e déficit logísticos em relação ao ciclo ideal, conforme mostra a Tabela 4.

Tabela 4. Estimativas do lead time total do ciclo logístico do transporte aéreo, em dias, e variação percentual de superávit e déficit logísticos em relação ao ciclo ideal

\begin{tabular}{crrrrrr}
\hline & \multicolumn{3}{c}{ Lead time (dias) } & & \multicolumn{2}{c}{ Variação percentual do } \\
\cline { 3 - 4 } Processos & \multicolumn{1}{c}{$\begin{array}{c}\text { déficit em } \\
\text { relação ao } \\
\text { ideal }\end{array}$} & $\begin{array}{c}\text { superávit em } \\
\text { relação ao } \\
\text { ideal }\end{array}$ \\
\cline { 2 - 3 } & Déficit & Ideal & Superávit & & $-1,10$ & 4,40 \\
A & 92,00 & 91,00 & 87,00 & & $-1,62$ & 29,15 \\
B & 1,10 & 1,08 & 0,77 & & $-7,69$ & 0,00 \\
C & 1,17 & 1,08 & 1,08 & & 0,00 & 0,00 \\
D & 2,00 & 2,00 & 2,00 & & \\
Ciclo logístico total & 96,27 & 95,17 & 90,85 & & & \\
\hline
\end{tabular}

Apesar das flores temperadas fazerem parte da cadeia do frio, pois necessitam de temperaturas mais baixas para a manutenção de sua qualidade e para sua maior durabilidade, nem todos os produtores que exportam possuem câmaras frias. Nesses casos, o transporte do produto até a central de distribuição pode ocorrer em veículos não refrigerados (para distâncias curtas), ou refrigerados (para distâncias maiores).

Um procedimento pós-colheita adotado é colocar as flores inicialmente numa área de resfriamento, diretamente na água, com temperatura de 12 a $15^{\circ} \mathrm{C} \mathrm{e}$, em seguida, embalá-las, transportá-las para câmaras frias de $2^{\circ} \mathrm{C}$ e depois proceder à paletização. Em geral, exportadores e cooperativas possuem câmaras frias para armazenar o produto até o momento da distribuição para o aeroporto. Nesses locais, podem ser realizadas as operações de pré-cooling e de paletização horas antes do embarque, podendo significar, em média, duas a três horas para paletizar $500 \mathrm{~kg}$ com auxílio de duas pessoas. Há a opção de transportar a carga ao aeroporto para que seja paletizada no local ou que se faça o seu envio em caixas soltas. Conforme salientam Welby \& McGregor (2004), há recomendações para diversas flores de corte quanto à umidade e temperatura ideais para seu armazenamento. 
Como a exportação de flores de corte é uma operação mais recente nos aeroportos, a paletização feita nesses locais pode causar perdas ao produto devido ao despreparo dos funcionários em manusear as caixas. Se houver muita carga, é procedimento comum "empurrarem as caixas com os pés" para que todas caibam nos pallets, danificando as flores.

Se houver reclamação sobre as perdas de carga, há indenização de $40 \%$ do valor pela companhia aérea dentro do período de dois a três anos da ocorrência do incidente. Por isso, de acordo com informações do setor de flores, é prática comum das companhias aéreas a assinatura de contrato com o exportador, que passa a assumir tal risco e seus custos associados. Com a intensificação das exportações em 2003, ocorreu iniciativa da companhia aérea UPS em treinar seus funcionários para manusear as caixas de flores, e de acordo com informações do setor, poderá inclusive construir câmara fria para transportar perecíveis nos seus galpões num dos aeroportos de São Paulo.

Após o armazenamento em câmara fria nas centrais de distribuição, é realizado o transporte rodoviário para o aeroporto. Alguns exportadores possuem caminhão próprio para transportar volumes menores e, para situações atípicas, também utilizam transporte terceirizado. No processo de distribuição interna pelo modal rodoviário, foi levado em conta o transporte terceirizado com caminhões refrigerados tanto para o aeroporto de Viracopos ou Guarulhos, cujos custos são cobrados por embarque. Até março de 2004 esses aeroportos concentravam a quase totalidade das exportações para os EUA, de acordo com Brasil (2004), sendo que entre 2000 e 2001 as flores de corte eram apenas exportadas por Guarulhos.

A partir de 2003 houve inversão da participação desses aeroportos, e Campinas tem concentrado por volta de $75 \%$ das exportações de flores de corte para os EUA. O aeroporto de Guarulhos concentrou a maioria dos embarques para a União Européia até dezembro de 2003, apesar de ter apresentado uma sensível redução ao longo dos anos. Essa situação foi alterada nos primeiros três meses de 2004, uma vez que esse aeroporto só embarcou cerca de $43 \%$ em relação ao total exportado no Brasil. O aeroporto de Fortaleza obteve crescimento de $69,40 \%$, aumentando sua participação de $26,80 \%$ em 2003 para 45,40\% em 2004 em relação ao total exportado de flores de corte brasileiras. 
Essa elevação provavelmente está relacionada aos incentivos da região para produção e exportação, principalmente de rosas ligadas à empresa Cearosa.

Para realizar as operações de importação ou exportação não é obrigatória a contratação de comissária de despachos, que coordena todas as atividades de comércio exterior, ou de despachante aduaneiro, que cuida da emissão de todos os documentos para o desembaraço aduaneiro, ou de agente de carga, que faz a reserva do espaço aéreo e negociação de frete junto à companhia aérea. Essas atividades também podem ser executadas pelo próprio exportador.

No caso das flores de corte o exportador, em geral, utiliza os serviços de agente de carga e de despachante aduaneiro para realizar todo o acompanhamento para conferir a liberação da carga pelo Ministério da Agricultura e pela Receita Federal até o momento da confirmação do embarque na companhia aérea, exceto nota fiscal e certificados fitossanitário e de origem (Form-A), que estão sob sua responsabilidade. É cobrada uma taxa de expediente, que pode ser paga diretamente pelo agente de carga através de nota fiscal de prestação de serviços ou no conhecimento de embarque (Airway Bill), na companhia aérea. A realização desse serviço pode variar em função do espaço disponível nos vôos e do retorno on-line dessa informação pelas companhias aéreas. De acordo com as exigências do país de destino, principalmente com relação à documentação fitossanitária, pode haver variação no tempo gasto para providenciar os documentos para o embarque. Em média, gasta-se em torno de uma hora para os despachos finais.

Em Viracopos há de 10 a 15 vôos cargueiros por dia, de acordo com o setor de flores. As tramitações de despacho aduaneiro levam em torno de duas horas. Se houver atraso, por conta da burocracia, as companhias aéreas cobram em torno US\$ 3,000.00 por hora de atraso no embarque. Uma câmara fria pequena, do tamanho de um baú pequeno, é utilizada preferencialmente para importação e em sobrando espaço, pode incluir os produtos destinados para exportação.

A escolha das companhias está mais vinculada aos seus procedimentos em relação à não ocorrência de atrasos e à existência de vôos diretos para produtos perecíveis, quaisquer que sejam os aviões, de passageiros ou cargueiros. Já foram 
registrados problemas com a qualidade das flores em função de falta de refrigeração em relação à companhia aérea de passageiros. No entanto, alguns entrevistados citaram como as seguintes companhias aéreas estrangeiras com procedimentos mais adequados à exportação de flores de corte: KLM, United Airlines e UPS. Comentaram também que uma companhia brasileira apresentou diversos problemas na exportação de flores de corte em decorrência de muitos atrasos e falhas em alguns embarques.

Há uma variação grande quanto aos valores aplicados ao frete aéreo, em função do período de tempo, do volume considerado, do estado de origem e da categoria do avião. Por exemplo, caso se necessite de uma faixa de temperatura entre 0 a $7^{\circ} \mathrm{C}$, os valores tarifários são mais altos; entre 15 a $20^{\circ} \mathrm{C}$, os valores tarifários são mais baixos.

Para a exportação de flores de corte, em geral, utiliza-se a faixa de 15 a $20^{\circ} \mathrm{C}$. Os valores dos fretes em Guarulhos ou Viracopos para Miami variaram muito após o atentado de 11/09/2002. Essa oscilação está diretamente ligada ao excesso ou falta de demanda de carga nos vôos. Foram registrados valores cobrados variando de US\$ 1.00 a 1.40 por $\mathrm{kg}$ para volume entre 300 a $500 \mathrm{~kg}$; US\$ 1.25 a 1.30 por kg para 100 a $300 \mathrm{~kg}$; US\$ 1.50 a US\$ 1.60 por kg para menos de $100 \mathrm{~kg}$. Para calcular os valores finais desses fretes, considerou-se que cada haste de lírio pesa em torno de 0,07 a 0,09 $\mathrm{kg}$ e de gérbera entre 0,03 e $0,04 \mathrm{~kg}$. A partir de 2003 foi inserido ao frete um adicional de taxa sobre o combustível, variando de US\$ 0.10 a US\$ 0.15 por $\mathrm{kg}$. Esse custo consta do conhecimento aéreo e pode ser pago pelo importador no país destino (frete collect) ou pago antecipado pelo exportador no Brasil (frete prepaid).

No Brasil é também cobrada taxa da Infraero para que a carga possa ficar armazenada e paletizada no aeroporto até a hora do seu embarque. Esse custo alfandegário é cobrado em US\$ por kg e é válido por até cinco dias após a entrada da mercadoria no aeroporto. Nos casos de perecíveis, como as flores, não é viável que a carga esteja sujeita a muitos atrasos para que seja embarcada, seja por problemas de desembaraço aduaneiro ou por falhas da companhia aérea. Isso pode, inclusive, inviabilizar a exportação desse tipo de produto, devido à perda de qualidade das flores de corte ao longo do tempo. 
Com o intuito de manter a cadeia do frio, uma alternativa encontrada pelos agentes é alugar mensalmente contêineres refrigerados nos aeroportos de Guarulhos e Viracopos, horas antes do embarque. Esse custo pode ser rateado entre produtor, cooperativa, exportador e importador.

O transporte rodoviário em Miami é feito, em geral, por transportadora contratada, que cobra de US\$ 3.00 a 4.00 por full. Essa terceirização é vantajosa em função do alto custo de operação com transporte próprio, que giraria em torno de US\$ 40-50 mil por mês.

No caso de prevenção fitossanitária, deve-se considerar a fumigação, que objetiva utilizar defensivos químicos para eliminar ovos de insetos presentes nas flores destinadas à exportação. Se o produtor não fizer a fumigação, há a necessidade do exportador ou cooperativa utilizar a sua câmara fria para realizar essa etapa, o que pode levar tempo adicional médio de três horas para embalar as flores. Nesse processo há também o custo de energia elétrica (de uma a três horas de uso) para pré-cooling. Há flores que não necessitam dessa etapa, como é o caso do lírio, ao contrário do crisântemo, gérbera e rosas, que precisam de fumigação.

Se essa etapa não for realizada e forem detectados insetos pela fiscalização fitossanitária nos EUA, para que o produto prossiga o processo de exportação é preciso realizar a fumigação em todos os produtos do lote com problemas, cujo custo é de aproximadamente de US\$ 150.00 por lote. No entanto, como há diversos tipos de flores, algumas delas podem ser mais sensíveis ao produto e serem queimadas. A eliminação total é realizada por meio de queima, com custo que pode variar de US\$ 300.00 a US\$ 400.00 por lote. Em caso de perda total, o produtor pode arcar com todas as despesas de frete, fumigação, novo envio do produto, sem custo para o importador ou pode ressarcir o cliente pelo não recebimento da mercadoria, na tentativa de amenizar a falha na entrega do produto.

Apesar de haver a possibilidade de ocorrer esses problemas no país de destino, há conscientização dos riscos dos agentes envolvidos em cada um dos processos. Embora haja a fiscalização do Ministério da Agricultura brasileiro para exportação de flores, de acordo com informações do setor, tal procedimento não é válido no exterior, em função 
do desprestígio do Brasil no exterior. Para tentar solucionar esse problema, houve ajuste da legislação fitossanitária brasileira às normas internacionais. Como não houve redação adequada das regras para fiscalização, em caso de dúvidas no procedimento, várias mercadorias foram bloqueadas ou inspecionadas com muito rigor. Como ainda não há infraestrutura apropriada para agilizar a fiscalização fitossanitária, esse procedimento acaba por contribuir para o aumento do tempo efetivo do processo exportador e da perda de qualidade das flores das caixas amostradas por variedade em cada lote embarcado. Além disso, essa vistoria nem sempre é realizada dentro da câmara fria e se for feita a paletização na central de distribuição, é preciso ainda desmontar os pallets.

Com o estímulo às exportações do agronegócio, mais especificamente do setor de flores, tem havido mobilização em vários âmbitos. Foi criada a Câmara Setorial Federal de flores e plantas ornamentais em 19 de junho de 2003, por determinação do Ministério da Agricultura, Pecuário e Abastecimento, como parte das medidas para alavancar as exportações, de acordo com Souza (2003). Dentre os pontos principais que devem ser tratados nesse fórum destacam-se logística de exportação, legislação fitossanitária e legislação tributária.

A inspeção fitossanitária nos EUA pode ser feita dentro ou fora da câmara fria, dependendo da companhia aérea utilizada. No caso da UPS, tal inspeção ocorre dentro da câmara fria; para outras companhias, em geral de passageiros, essa operação é realizada fora da câmara fria, sujeito aos mesmos problemas detectados no Brasil. No aeroporto de Miami, antes de se retirar a mercadoria, pode ser realizado o pré-cooling, cujo custo gira em torno de US\$ 1.00 por caixa. De acordo com Welby \& McGregor (2004) o sucesso desse procedimento depende principalmente do tempo entre a colheita e a sua realização, tipo de contêiner embarcado, caso tenha sido embalado previamente, temperaturas inicial e final do produto, velocidade de ar frio utilizado e manutenção da temperatura recomendada após essa operação. 


\subsection{Cenários logísticos}

Para avaliar as mudanças no desempenho de cada um dos processos e da cadeia como um todo, foram realizadas alterações nas relações entre os agentes da cadeia, por meio da construção de cenários. Estes foram definidos a partir da constatação de problemas relevantes que poderão ocorrer na cadeia, gerando ineficiências em um ou mais processos. Na composição desses cenários, foram identificados parâmetros técnicos, principalmente relacionados à logística, que pudessem interferir na exportação de flores de corte, descritos a seguir:

a) número de hastes por caixa, que pode variar de acordo com as exigências do cliente e do tipo de flor (75, 80 ou 100 hastes);

b) taxa de câmbio nominal em real por dólar e euro, pois tanto os insumos importados quanto os produtos são cotados numa dessas moedas ou em ambas;

c) fretes rodoviários para o aeroporto - Guarulhos ou Viracopos - cujos valores variam em função da distância a partir do ponto de origem;

d) consórcio logístico, que permite o rateio de algumas despesas relativas à distribuição dos produtos até aeroporto devido ao pequeno volume exportado, sendo em média de quatro produtores, de pequeno a médio porte, por embarque;

e) número de embarques, que podem variar de dois por semana a três por dia, dependendo da época do ano e do volume de flores disponível para embarque;

f) frete aéreo, que pode variar em função do volume exportado por embarque e das negociações com as companhias aéreas;

g) porcentagem de perda de flores em cada um dos processos, devido às falhas na póscolheita, no armazenamento e no transporte do ponto de origem ao destino final;

h) eficiência do ciclo do pedido, que pode detectar déficit ou superávit na condução de cada um dos processos, podendo gerar reduções ou acréscimos no valor final das flores, conforme apresentado na Tabela 4;

i) número de horas extras que o caminhão permanece no aeroporto com as flores antes do embarque, em Guarulhos ou Viracopos, em função de atrasos no embarque ou na documentação aduaneira; 
j) aluguel de contêiner refrigerado ("câmara fria") no aeroporto de Guarulhos ou Viracopos, para manter a temperatura das flores entre 2 e $3^{\circ} \mathrm{C}$;

k) fumigação das flores pelo exportador antes do embarque no Brasil, caso essa etapa não tenha sido executada previamente;

1) fumigação das flores no aeroporto nos EUA, devido à detecção de insetos nas flores após inspeção fitossanitária;

m) falta de refrigeração no veículo que transporta as flores do produtor ao centro de distribuição, localizado dentro da cooperativa ou no depósito do exportador;

n) perda física da carga no vôo, por problemas de qualidade das flores, decorrentes de falhas na cadeia do frio até o embarque da mercadoria;

o) pré-cooling no aeroporto EUA, para oferecer uma sobrevida maior às flores até o consumidor final;

p) atraso no vôo no Brasil por problemas no desembaraço aduaneiro, com pagamento adicional à companhia aérea para embarcar a carga nesse vôo.

Esses parâmetros foram mantidos fixos na construção de cada um dos 5 cenários, com exceção do número de hastes por caixa, da taxa de câmbio e do frete aéreo. Como a variação desses últimos poderia causar alterações mais significativas no desempenho da cadeia, cada uma das combinações de seus valores caracterizou uma simulação.

As taxas de câmbio do dólar americano e do euro em relação ao real constituemse em parâmetros importantes para a cadeia, pois afetam tanto os insumos quanto os produtos nela gerados. A Figura 9 apresenta os dados dos últimos cinco anos, de janeiro de 1999 a janeiro de 2004. Desse período, a princípio, foram extraídos três pontos, relativos aos valores mínimo, médio e máximo da série, para tentar captar a sua influência em diferentes situações, ou seja, R\$ 1,50 por dólar (ou R\$ 1,60 por euro) de janeiro de 1999, $\mathrm{R} \$ 2,41$ por dólar (ou $\mathrm{R} \$ 2,10$ por euro) de fevereiro de 2002 e $\mathrm{R} \$ 3,81$ por dólar (ou R\$3,73 por euro) de outubro de 2002. 


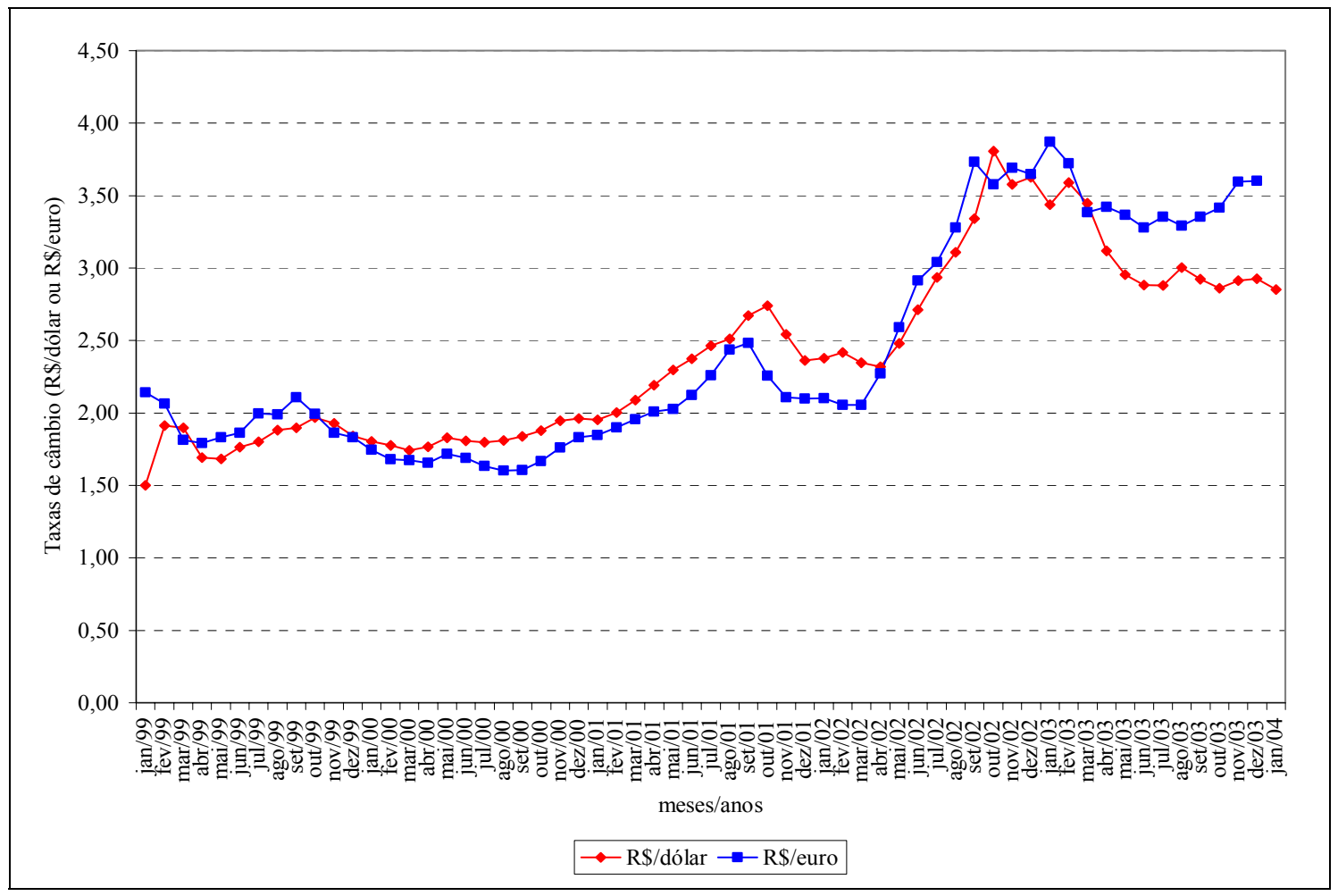

Figura 9 - Taxas de câmbio nominais, reais por dólar americano e euro, de janeiro/1999 a janeiro/2004

Fonte: Banco Central do Brasil (2004)

Assim sendo, foram analisadas 36 simulações, provenientes das combinações das três taxas de câmbio ( $\mathrm{R} \$ 1,50, \mathrm{R} \$ 2,41$ e $\mathrm{R} \$ 3,81$ por dólar) com três quantidades de hastes por caixa $(75,80$ ou 100 hastes) e com quatro valores de fretes aéreos (US\$ 1.10 por $\mathrm{kg}$, US\$ 1.25 por $\mathrm{kg}$, US\$ 1.40 por $\mathrm{kg}$ e US\$ 1.50 por $\mathrm{kg}$ ), conforme mostra a Tabela 5. Foram fixados dois embarques semanais para o aeroporto de Viracopos para cada uma das cadeias dos produtos lírio e gérberas 1 e 2, supondo que todos são exportados para Miami mediante um consórcio logístico, com rateio das despesas entre quatro produtores. 
Tabela 5. Simulações efetuadas para a construção de cada um dos cenários, para cada um dos tipos de flores lírio e gérberas 1 e 2

\begin{tabular}{|c|c|c|c|c|c|c|c|}
\hline \multirow[b]{2}{*}{$\begin{array}{l}\text { Simu- } \\
\text { lação }\end{array}$} & \multicolumn{3}{|c|}{ Parâmetros } & & \multicolumn{3}{|c|}{ Parâmetros } \\
\hline & $\begin{array}{c}\text { Número } \\
\text { de } \\
\text { hastes }\end{array}$ & $\begin{array}{c}\text { Frete } \\
\text { Aéreo } \\
\text { (US\$/kg) }\end{array}$ & $\begin{array}{c}\text { Taxa de } \\
\text { câmbio } \\
(\mathrm{R} \$ / \mathrm{US} \$)\end{array}$ & $\begin{array}{l}\text { Simu- } \\
\text { lação }\end{array}$ & $\begin{array}{c}\text { Número } \\
\text { de } \\
\text { hastes }\end{array}$ & $\begin{array}{l}\text { Frete } \\
\text { aéreo } \\
(\mathrm{US} \$ / \mathrm{kg})\end{array}$ & $\begin{array}{l}\text { Taxa de } \\
\text { câmbio } \\
(\mathrm{R} \$ / \mathrm{US} \$)\end{array}$ \\
\hline 1 & 75 & 1.10 & 1,50 & 19 & 80 & 1.40 & 1,50 \\
\hline 2 & 75 & 1.10 & 2,41 & 20 & 80 & 1.40 & 2,41 \\
\hline 3 & 75 & 1.10 & 3,81 & 21 & 80 & 1.40 & 3,81 \\
\hline 4 & 75 & 1.25 & 1,50 & 22 & 80 & 1.50 & 1,50 \\
\hline 5 & 75 & 1.25 & 2,41 & 23 & 80 & 1.50 & 2,41 \\
\hline 6 & 75 & 1.25 & 3,81 & 24 & 80 & 1.50 & 3,81 \\
\hline 7 & 75 & 1.40 & 1,50 & 25 & 100 & 1.10 & 1,50 \\
\hline 8 & 75 & 1.40 & 2,41 & 26 & 100 & 1.10 & 2,41 \\
\hline 9 & 75 & 1.40 & 3,81 & 27 & 100 & 1.10 & 3,81 \\
\hline 10 & 75 & 1.50 & 1,50 & 28 & 100 & 1.25 & 1,50 \\
\hline 11 & 75 & 1.50 & 2,41 & 29 & 100 & 1.25 & 2,41 \\
\hline 12 & 75 & 1.50 & 3,81 & 30 & 100 & 1.25 & 3,81 \\
\hline 13 & 80 & 1.10 & 1,50 & 31 & 100 & 1.40 & 1,50 \\
\hline 14 & 80 & 1.10 & 2,41 & 32 & 100 & 1.40 & 2,41 \\
\hline 15 & 80 & 1.10 & 3,81 & 33 & 100 & 1.40 & 3,81 \\
\hline 16 & 80 & 1.25 & 1,50 & 34 & 100 & 1.50 & 1,50 \\
\hline 17 & 80 & 1.25 & 2,41 & 35 & 100 & 1.50 & 2,41 \\
\hline 18 & 80 & 1.25 & 3,81 & 36 & 100 & 1.50 & 3,81 \\
\hline
\end{tabular}

Em cada um dos cenários e simulações foram utilizadas as variáveis principais custos, receitas e lucros calculados para a cadeia como um todo e para cada um dos processos a partir do modelo proposto no capítulo 3. Os lucros unitários de cada um dos processos da produção das flores foram empregados para estudar cada etapa separadamente. Os lucros brutos relacionam-se à produção bruta de cada processo e os finais estão associados a cada unidade vendida aos consumidores finais. No Anexo B estão descritos os resultados obtidos na análise de cada um dos cenários para cada uma das flores estudadas.

Para auxiliar na análise da cadeia de cada uma das flores estudadas, foram geradas variáveis auxiliares, ou seja, proporção entre custo e lucro totais, porcentagem de custos logísticos em relação ao custo total, porcentagem de insumos utilizados em cada um dos processos e índices de custo, receita e lucro total para toda a cadeia. Para 
cada uma das flores optou-se por utilizar a primeira simulação de cada um dos cenários como base do índice igual a 100, pois agrega os menores valores de taxa de câmbio, número de hastes por embalagem e taxa de frete aéreo. O fluxo de informações do modelo está descrito na Figura 10. 


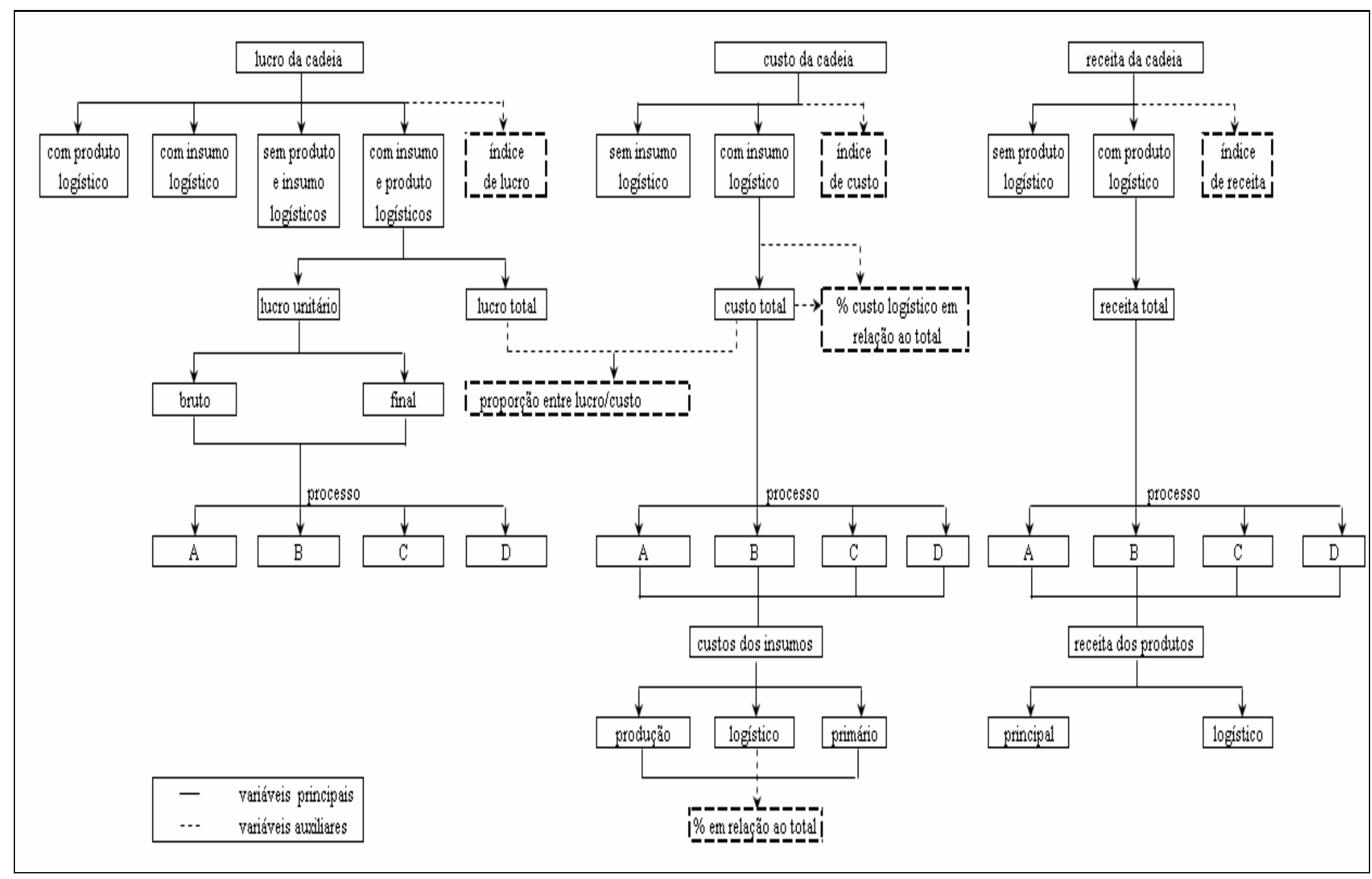

Figura 10 - Fluxo das informações no modelo insumo-produto de processo 


\subsubsection{Cenário 1: déficit logístico em todos os processos da cadeia}

Neste cenário foram utilizadas as perdas médias relatadas pelos agentes em cada um dos processos, ou seja, 10\% para o processo de produção (A), $0 \%$ para o processo de distribuição interna via modal rodoviário (B), 2\% para o processo de distribuição externa via modal aéreo (C) e 3\% para o processo de distribuição externa via modal rodoviário (D), assumindo que havia déficit logístico na eficiência do ciclo do pedido, com investimento apenas no processo de produção, de 10\%. O veículo que transportou as flores do produtor para a central de distribuição não possuía refrigeração. Nesse caso, não foi utilizado contêiner ("câmara fria") no aeroporto e nem foi feita fumigação ou pré-cooling nos aeroportos no Brasil ou EUA e não houve perda de carga no vôo. A Figura 11 apresenta os custos, receitas e lucros totais para a cadeia do lírio nas 36 simulações desse Cenário 1.

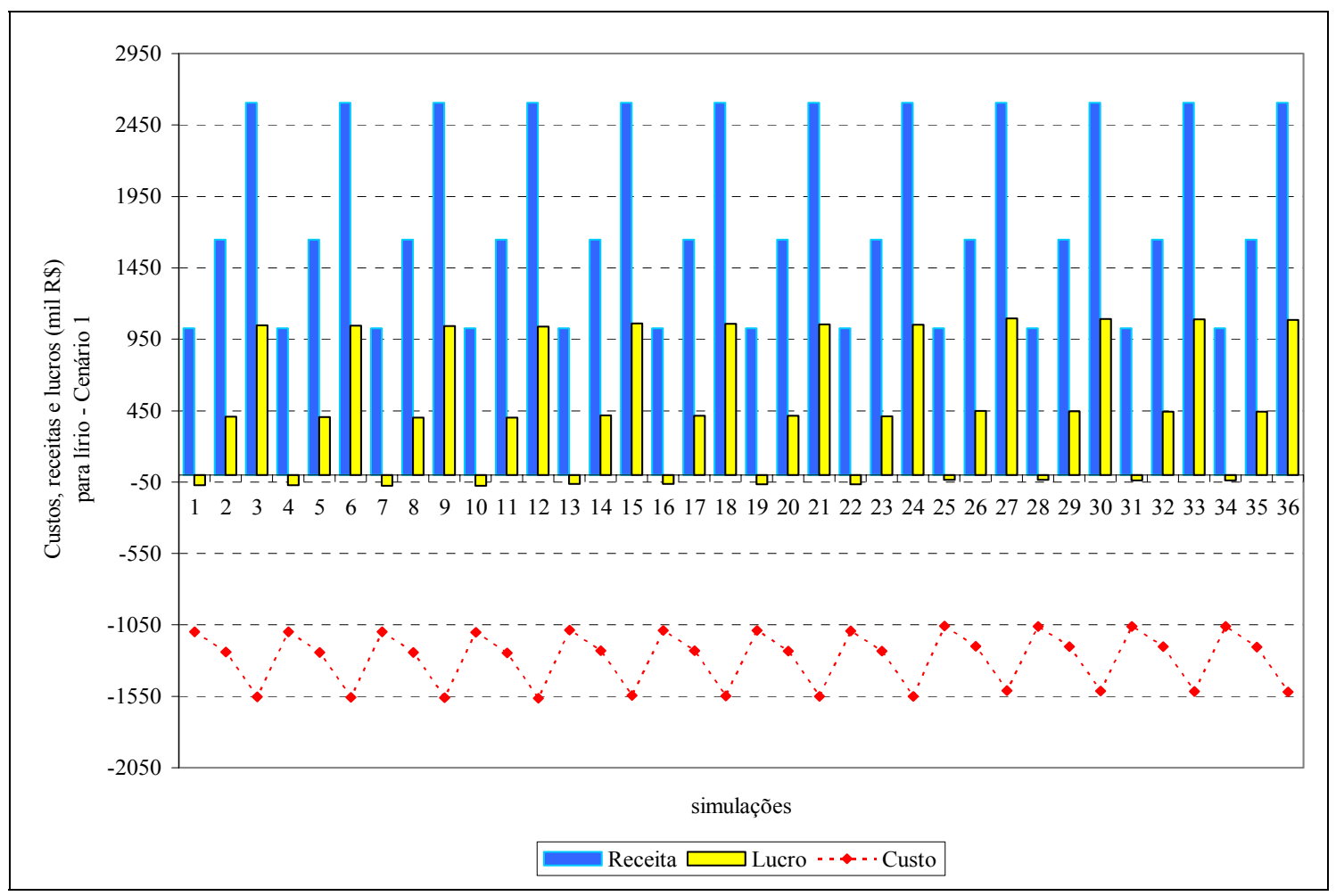

Figura 11 - Custos, receitas e lucros totais para a cadeia de lírio nas 36 simulações do Cenário 1 
A valorização do dólar em relação ao real foi o principal componente que afetou os valores das simulações desse cenário. Já se pôde notar a influência positiva do câmbio no seu valor intermediário ( $\mathrm{R} \$ 2,41$ por dólar), elevando os lucros em torno de $660 \%$ em relação à primeira simulação. Nos pontos em que o câmbio atingiu seu valor máximo (R\$ 3,81 por dólar) - nas simulações 3, 6, 9, 12 e assim por diante - houve elevação de $154 \%$ na receita total e observou-se tendência de redução nos custos totais em relação à primeira simulação. Isso se verifica em função de alguns insumos de produção, logísticos e primários e dos preços das flores, que são cotados em moeda estrangeira. As variações no câmbio captaram com maior intensidade os reflexos positivos do lucro total, minimizando os efeitos das alterações no número de hastes e no valor do frete aéreo, tendo como conseqüência oscilações pequenas nas demais simulações.

Ao considerar cada processo separadamente dos demais, apenas os lucros unitários brutos do processo de distribuição externa via modal rodoviário (processo D) destacaram-se positivamente em todas as simulações, conforme mostra a Figura 12(a). Seus maiores valores atingiram entre $\mathrm{R} \$ 0,40$ e $\mathrm{R} \$ 1,10$ por unidade da produção bruta do produto principal, enquanto no processo de produção (A) seus lucros ficaram abaixo de R\$ 0,40 por unidade da produção final do produto principal. O processo de distribuição externa via modal aéreo (C) foi o único que apresentou lucros brutos negativos, pois como é uma etapa que não agrega nenhum valor à cadeia, está sujeito às perdas de qualidade do produto em decorrência de problemas nessa etapa, como por exemplo, maiores atrasos na sua distribuição entre os locais de origem e destino. 


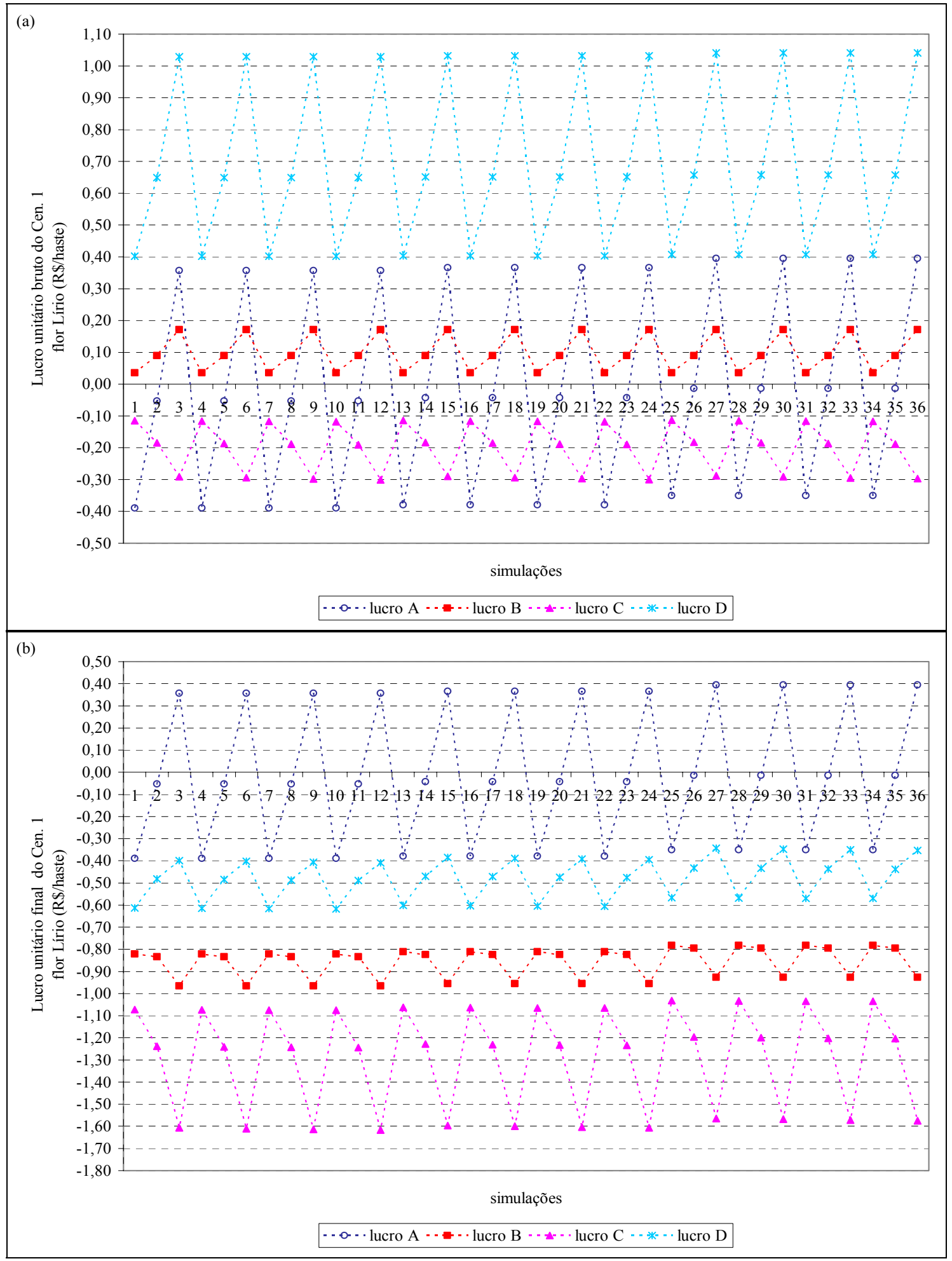

Figura 12 - Comparação dos lucros unitários de cada um dos processos para as produções bruta (a) e final (b) da flor lírio nas 36 simulações do Cenário 1 
Os principais condicionantes da situação mostrada no processo A são o manuseio de insumos importados, principalmente bulbos, devido à maior concentração dos custos nesse item e à sua maior sensibilidade às oscilações da taxa de câmbio, e os cuidados pós-colheita, que são determinantes para que o produto mantenha sua qualidade ao longo da cadeia. Os custos do processo (D) estão associados principalmente ao frete rodoviário, inserido nos insumos logísticos. Ambos processos foram muito suscetíveis às variações do câmbio, concentrando os maiores ganhos unitários, mas também as maiores perdas.

Nota-se que o lucro final do processo de produção (A), expresso na Figura 12(b), corresponde ao lucro bruto. Isso ocorreu porque esse processo localiza-se no início da cadeia e, portanto, não há incremento no lucro final da cadeia proveniente de etapas anteriores. Apenas esse processo possui valores positivos nos pontos com maiores valores da taxa de câmbio para os lucros de cada unidade da produção final do produto principal nesse cenário. Os processos de distribuição interna via modal rodoviário (B) e de distribuição externa via modal rodoviário (D) sofreram oscilações menores em comparação ao processo de distribuição externa via modal aéreo (C). Isso se justifica, pois este último não agrega valor e possui forte influência dos insumos logísticos, principalmente os relacionados ao desembaraço aduaneiro e ao frete aéreo, que determinaram a amplitude de suas perdas em relação ao consumidor final.

Na Figura 13 estão apresentados os custos, receitas e lucros totais da flor gérbera 1. Neste caso observa-se que apenas houve elevação positiva nos lucros totais quando a taxa de câmbio atingiu seu valor máximo ( $\mathrm{R} \$ 3,81$ por dólar). Nesse patamar os custos totais tiveram tendência de queda e reduções médias de aproximadamente $23 \%$ em relação à primeira simulação. Ao se comparar este produto com o anterior, observa-se que houve recuperação mais lenta de sua receita com a elevação do câmbio, apesar de registrar menores impactos nos seus insumos e produtos com a oscilação do dólar em relação ao lírio, pois essa cadeia exporta volumes menores do que a anterior. Os custos e receitas totais da cadeia de gérbera 1 foram, em média, $80 \%$ e $86 \%$ mais baixos do que a cadeia anterior, respectivamente. 


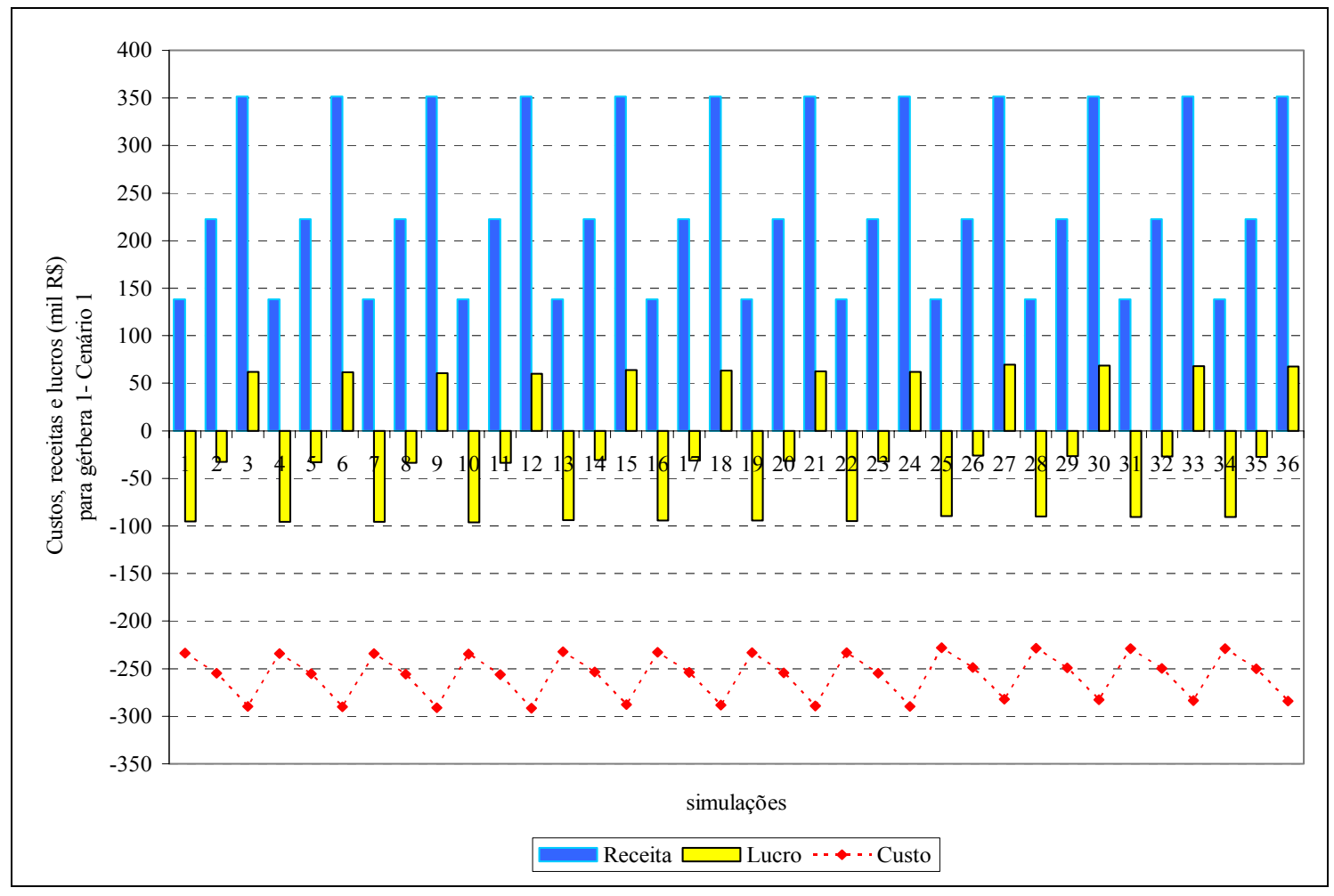

Figura 13 - Custos, receitas e lucros totais para a cadeia de gérbera 1 nas 36 simulações do Cenário 1

Em relação aos lucros unitários brutos da cadeia da flor gérbera 1, mostrados na Figura 14(a), nota-se que o processo de distribuição externa via modal rodoviário (processo D) foi o único que apresentou valores positivos em todas as simulações, o mesmo ocorrido na flor lírio. Por essa variável bruta considerar cada processo como gerador do produto final, o processo (D) concentrou os maiores lucros e os menores custos em relação aos processos anteriores. Seus lucros oscilaram de R \$ 0,19 a R 0,52 por haste, o que corresponderam a valores $50 \%$ menores do que a cadeia anterior. 


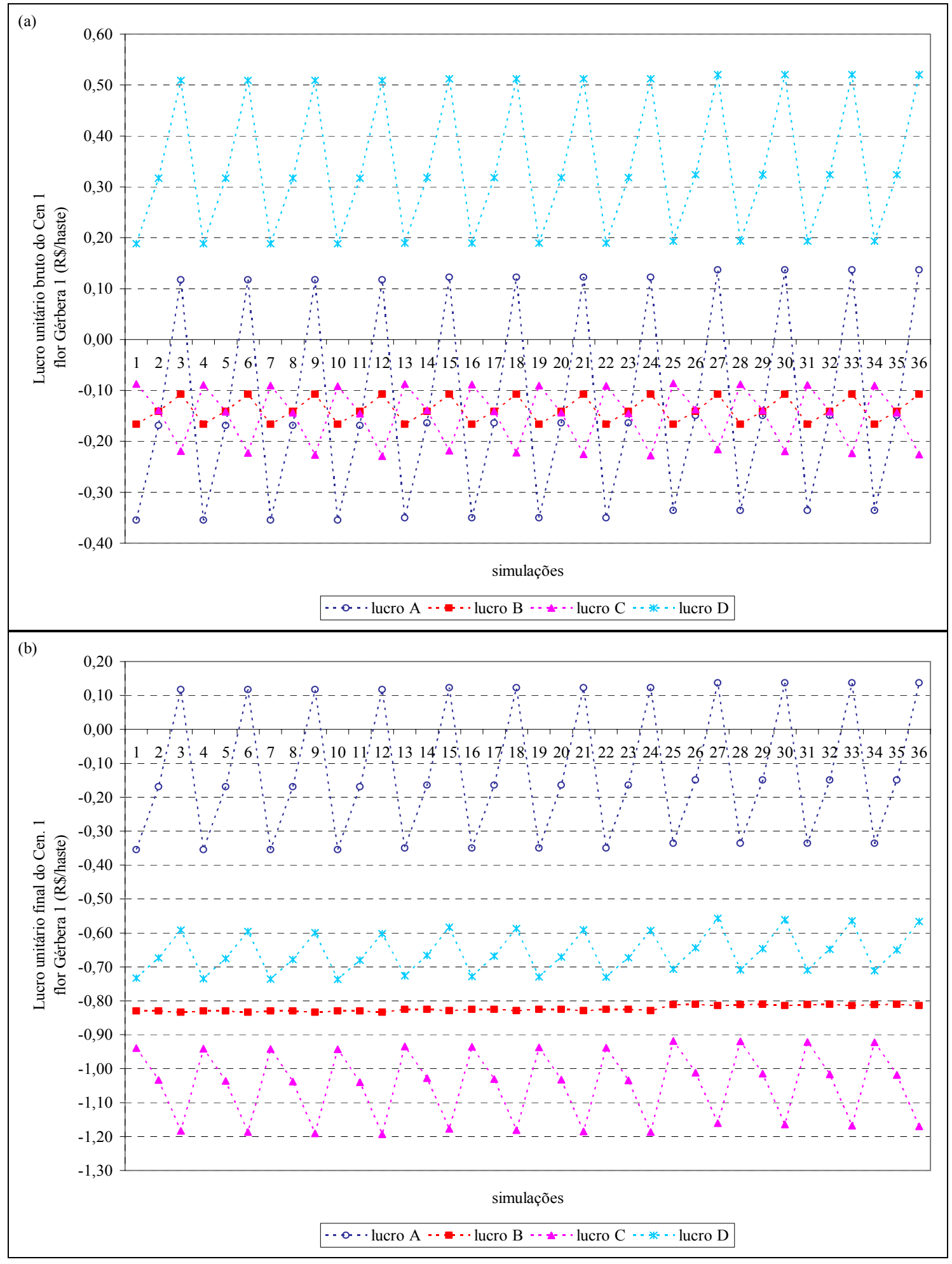

Figura 14 - Comparação dos lucros unitários de cada um dos processos para as produções bruta (a) e final (b) de gérbera 1 nas 36 simulações do Cenário 1 
Ao considerar a interação entre os processos para gerar um produto no final da cadeia, o processo A obteve lucros positivos bem pequenos apenas com o câmbio mais valorizado. Os demais sofreram prejuízos em todas as simulações, conforme é apresentado na Figura 14(b). O processo (C) concentrou as maiores perdas no lucro unitário e o processo A as menores, semelhante à flor anterior, porém com magnitudes próximas em cada etapa, apesar do valor exportado do lírio ter sido, neste caso, em torno de sete vezes maior do que o da gérbera 1 .

O processo de distribuição interna via modal rodoviário (processo B) apresentou as menores variações nos lucros finais, mesmo que houvesse variações no número de hastes e na taxa de câmbio. Isso ocorreu, provavelmente, pois nessa etapa foi considerado déficit logístico nulo e foi identificada a ocorrência de acordo entre as partes na prestação de alguns serviços, como é o caso do frete rodoviário do centro de distribuição ao aeroporto, reduzindo a interferência da taxa de câmbio em relação aos outros processos.

A cadeia de gérbera 2 diferenciou-se das anteriores por apresentar lucros positivos a partir dos níveis mais baixos de câmbio, com as menores taxas de frete aéreo. A Figura 15 mostra os custos, receitas e lucros totais dessa cadeia. Seus custos e lucros totais atingiram valores intermediários em relação às outras duas cadeias analisadas. Os custos da gérbera 2 foram, em média, $60 \%$ superiores aos da gérbera 1 e $68 \%$ inferiores aos do lírio. Da mesma forma que nas cadeias de lírio e gérbera 1, os custos totais desta cadeia tenderam a diminuir ao longo das simulações. 


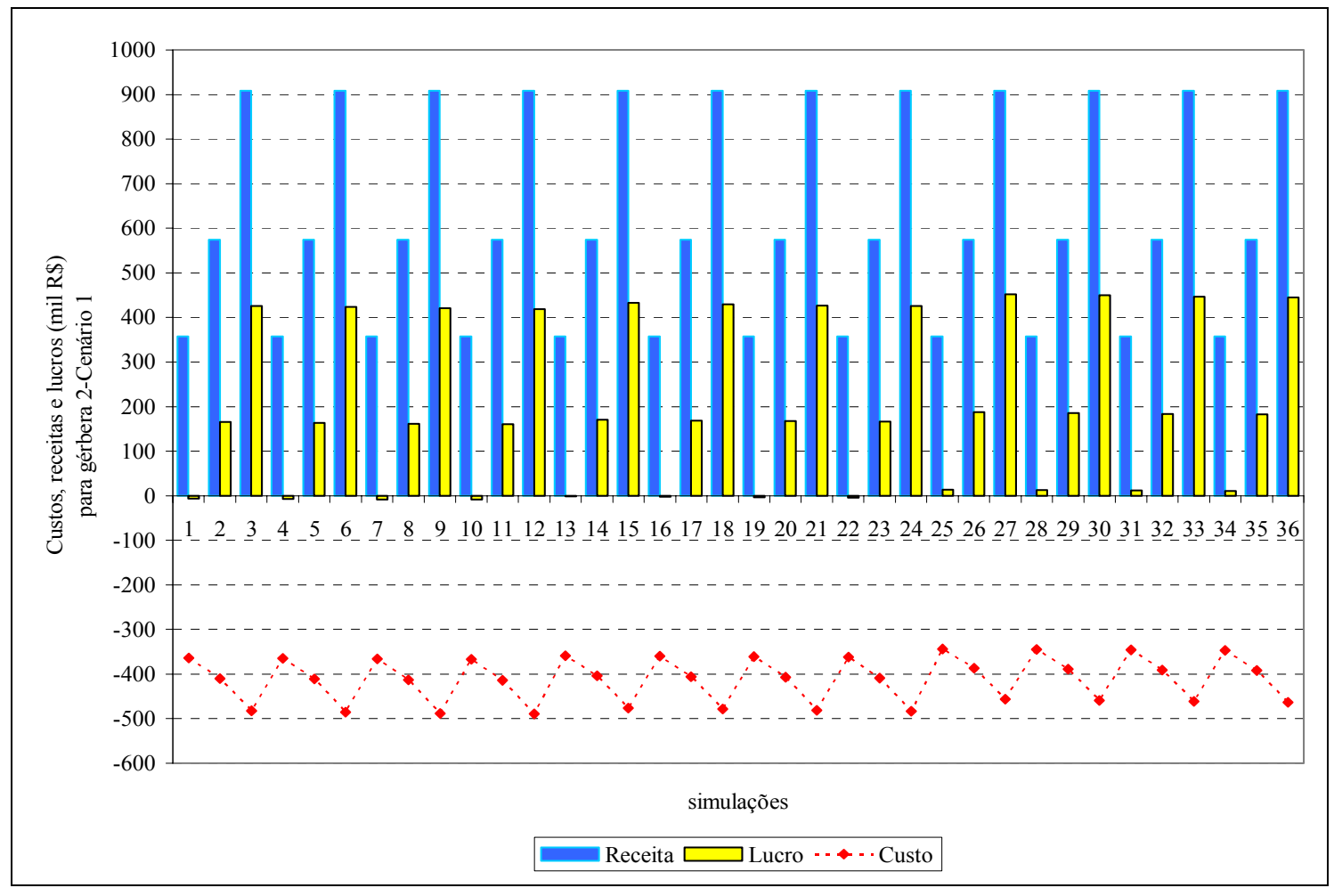

Figura 15 - Custos, receitas e lucros totais para a cadeia de gérbera 2 nas 36 simulações do Cenário 1

Em todas as cadeias de flores verificou-se tendência de elevação dos lucros unitários dos processos de produção (A) e de distribuição externa via modal rodoviário (D) a partir da $25^{\mathrm{a}}$ simulação, na qual há aumento do número de hastes por caixa para 100, como se observa na Figura 16, por exemplo, para a gérbera 2. Isso é provavelmente reflexo direto do ganho em escala, a partir da utilização do maior número de hastes por caixa. 


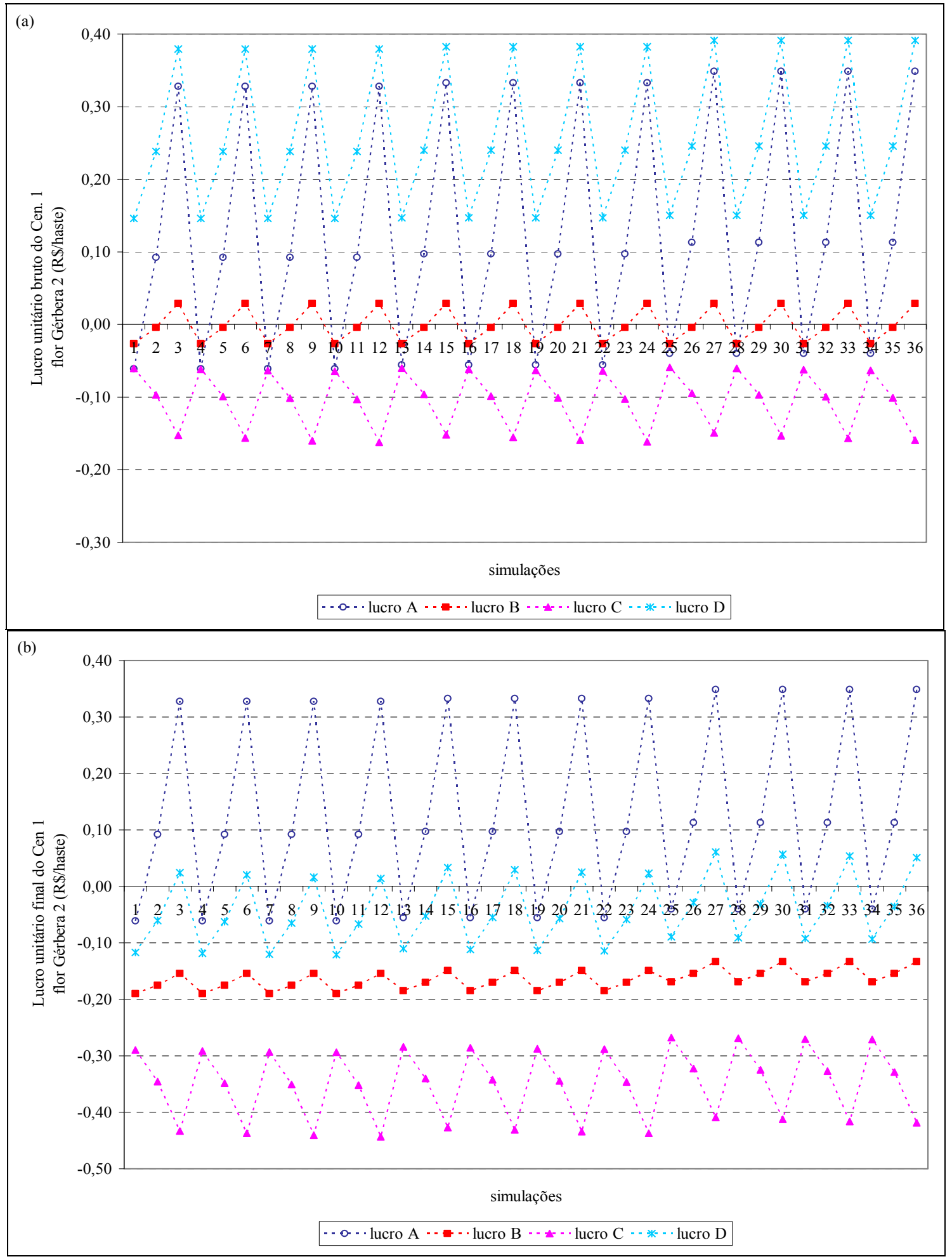

Figura 16 - Comparação dos lucros unitários de cada um dos processos para as produções bruta (a) e final (b) da flor gérbera 2 nas 36 simulações do Cenário 1 
Em relação aos lucros unitários finais, no processo de produção (A) foram registradas as maiores oscilações desses valores, expressos na Figura 16(b). Na distribuição interna via modal rodoviário (B), registrou-se os menores prejuízos, entre $\mathrm{R} \$ 0,10$ e R \$ 0,20 por haste, apesar de possuir lucro bruto unitário positivo nos pontos com as maiores valorizações do real em relação ao dólar. Isso reflete o acúmulo de prejuízos a partir do processo inicial na produção do produto final. De maneira geral, à medida que houve maior adensamento das hastes nas caixas, variando de 75 ou 80 para 100, houve elevação mais acentuada nos lucros finais dos processos dessa cadeia.

Ao se considerar que no mercado americano, de acordo com Liemt (1999), os importadores estão cada vez mais sendo representados pelos supermercados, que priorizam a qualidade e depois o preço, as condições físicas do produto determinam o grau de competitividade da flor brasileira exportada. Dentre os fatores limitantes da qualidade das flores brasileiras há problemas relacionados a: genoma da flor; fitossanidade (como é o caso do botritis); adubação; ponto de colheita (que interfere no ponto de abertura); cuidados pós-colheita, como a escolha da embalagem adequada e necessidade de transporte da mercadoria em caminhões refrigerados, para que não ocorram cones quebrados, flores amassadas e danos mecânicos.

Os produtores norte-americanos estão segmentando cada vez mais seus produtos para atender à demanda das grandes redes de lojas, com foco na qualidade, serviço e entregas mais freqüentes. De acordo com Brumfield (2003), em pesquisa realizada em 2001, em New Jersey, um dos dez maiores estados que produzem flores e plantas ornamentais, constatou-se entre os produtores grande preocupação em reduzir custos para manter sua competitividade, intensificando investimento no gerenciamento do negócio. Os fatores ambientais foram considerados de difícil controle, como insetos, doenças e temperatura e ainda foi detectado uso intensivo de defensivos químicos.

Neste cenário deve-se destacar que as falhas no processo produtivo e na distribuição interna até o aeroporto, com déficit logístico na cadeia, implicaram redução da eficiência na exportação das flores, principalmente em se tratando de pequeno volume comercializado. Deve-se atentar para o fato de que se verificou o desempenho de cada processo, e não necessariamente de cada agente da cadeia. Desta forma, 
dependendo do acordo efetuado entre as partes, os custos de cada etapa podem ser repassados para os produtores, exportadores ou importadores, afetando seus lucros e custos.

De acordo com Couto (2002), tem havido maior conscientização entre os produtores brasileiros quanto à necessidade de efetuar cuidados pós-colheita, principalmente com relação às flores de corte, para ampliar a vida útil do produto. Se houver incentivo às pesquisas nessa área para prover tecnologia mais adequada para a sua melhor conservação, os impactos externos à qualidade da flor poderão ser minimizados. No âmbito da produção das flores, adaptação e desenvolvimento de técnicas mais avançadas para a conservação do produto serão importantes para que os produtores tornem-se mais eficientes nessa etapa. Além disso, um dos investimentos prioritários é a instalação de câmaras frias em suas propriedades. Se existirem relacionamentos mais duradouros de negócios, há a possibilidade de se buscar parcerias com os outros agentes do sistema para viabilizar a sua implantação, inclusive com rateamento de parte de seus custos. Com a melhoria desse processo, todos os agentes da cadeia ganham com a melhoria da qualidade das flores, aumentando a competitividade da mercadoria exportada.

Além desses fatores operacionais, a freqüência nas exportações é condicionante importante para construir as relações entre os agentes no longo prazo e conquistar permanentemente o mercado externo. Centre for the Promotion of Imports from Developing Countries (2002) acrescenta que há boas oportunidades de negócios para importação de produtos de qualidade de países em desenvolvimento para a Europa se essas condições forem cumpridas, mesmo em períodos em que os preços internacionais não forem vantajosos. Além disso, há possibilidade de mercado para produtos diferenciados dos disponíveis nos países importadores, como é o caso de flores tropicais brasileiras.

As características das flores, que influenciam nos preços internacionais, estão relacionadas à uniformidade das hastes, cores e quantidade de folhas, ausência de resíduos de defensivos químicos e da presença de insetos ou de doenças, temperatura das flores, ponto de abertura e sua sazonalidade, conforme Centre for the Promotion of 
Imports from Developing Countries (2003). Como as flores são produtos altamente perecíveis, a manutenção de temperaturas mais baixas e adequadas durante todas as etapas reduz a incerteza na sua qualidade final.

\subsubsection{Cenário 2: déficit logístico na cadeia, com maiores cuidados no processo de produção}

Neste cenário foi reduzida a perda observada no processo de produção (processo A) para 5\% e mantidos os demais níveis de perdas assumidos para os outros processos no Cenário 1, admitindo que ainda havia déficit logístico na eficiência do ciclo do pedido, sem refrigeração do veículo que transportou as flores do produtor para a central de distribuição. Nesse caso também não foi utilizado contêiner ("câmara fria") no aeroporto e nem foi feita fumigação ou pré-cooling nos aeroportos no Brasil ou nos EUA e não houve perda de carga no vôo. Custos, receitas e lucros totais para a cadeia do lírio nas 36 simulações desse cenário foram comparados, conforme mostra a Figura 17.

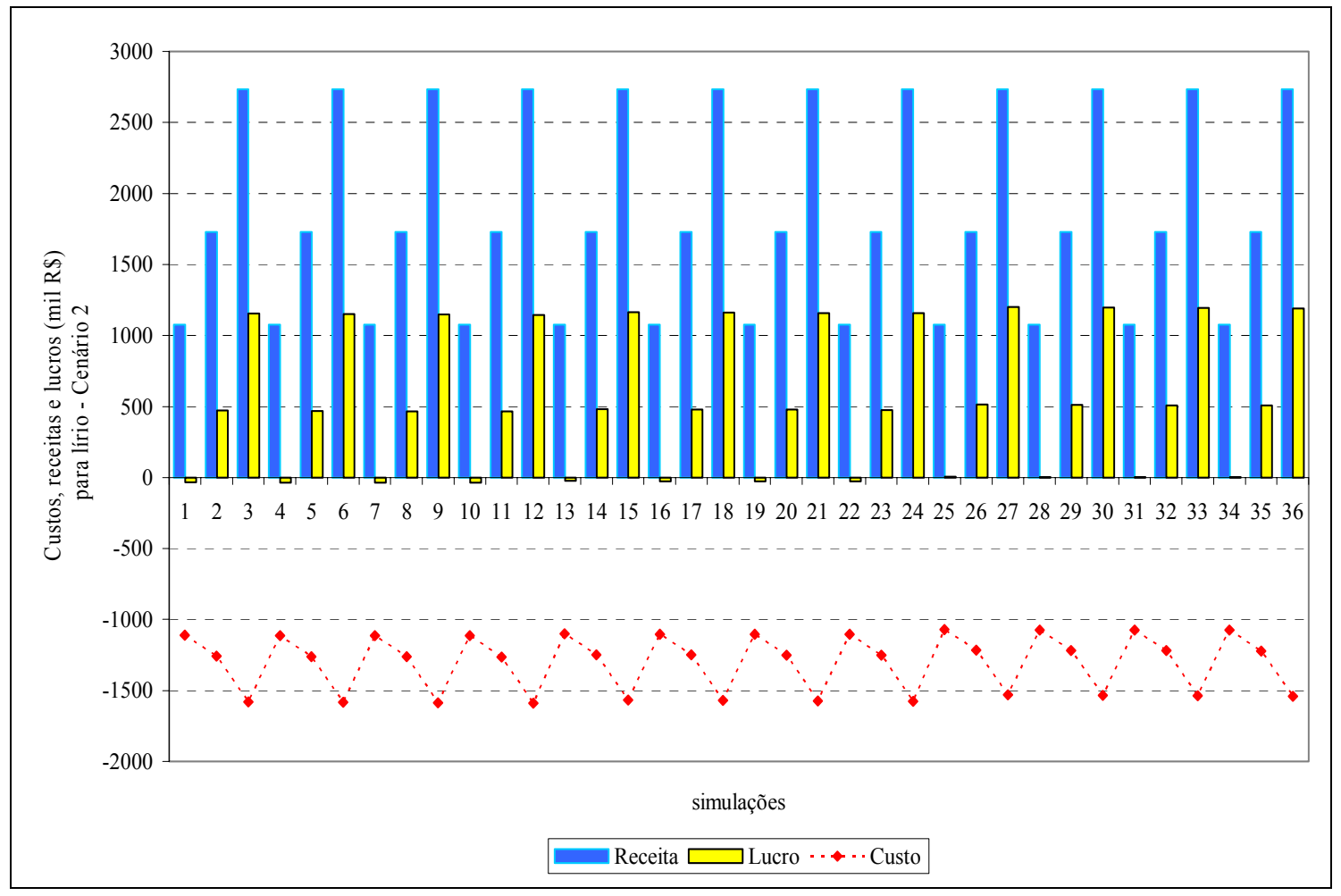

Figura 17 - Custos, receitas e lucros totais para a cadeia de lírio nas 36 simulações do Cenário 2 
Como foram registradas menores perdas no processo de produção (processo A), houve reflexos positivos na cadeia, em função do aumento da receita total em relação ao cenário anterior em 5\%. Apesar da elevação nos custos em 1,40\%, em média, para o lírio, em função do maior número de hastes comercializadas, os lucros aumentaram em relação ao cenário anterior, repercutindo também em prejuízos bem menores para a cadeia como um todo nos valores mais baixos das taxas de câmbio. Com o aumento para 100 hastes por embalagem constatou-se lucros positivos mesmo em taxas de R\$ 1,50 por dólar, o que não foi verificado no Cenário 1 .

A Figura 18 apresenta os lucros unitários brutos e finais para cada um dos processos dessa cadeia. Com o aumento de 5\% no número de hastes produzidas a partir do processo de produção (A), isso afetou positivamente todos os processos seguintes, pois sofreram diminuição nos seus prejuízos em relação ao cenário anterior. O processo de distribuição externa via modal rodoviário (D) registrou os maiores lucros brutos positivos, que oscilaram entre R $\$ 0,40$ e $\mathrm{R} \$ 1,10$ por haste. Essa alteração na cadeia, no entanto, não foi suficiente para refletir positivamente na eficiência do ciclo do pedido e na redução do déficit logístico. Seria necessário que houvesse aperfeiçoamento em outros parâmetros dos processos, como por exemplo, o maior controle da temperatura das flores. De acordo com Lim e Tam (2001), em estudos realizados na Austrália em que esse item foi monitorado no transporte aéreo da cadeia logística de flores de corte, houve melhoria da qualidade do produto e da rentabilidade econômica, a partir de um controle mais eficiente da temperatura, registrando no caso da orquídea um aumento de uma semana na durabilidade da flor. Estudos direcionados para a realidade brasileira são importantes para que se possa ajustar melhor a qualidade do produto final. 


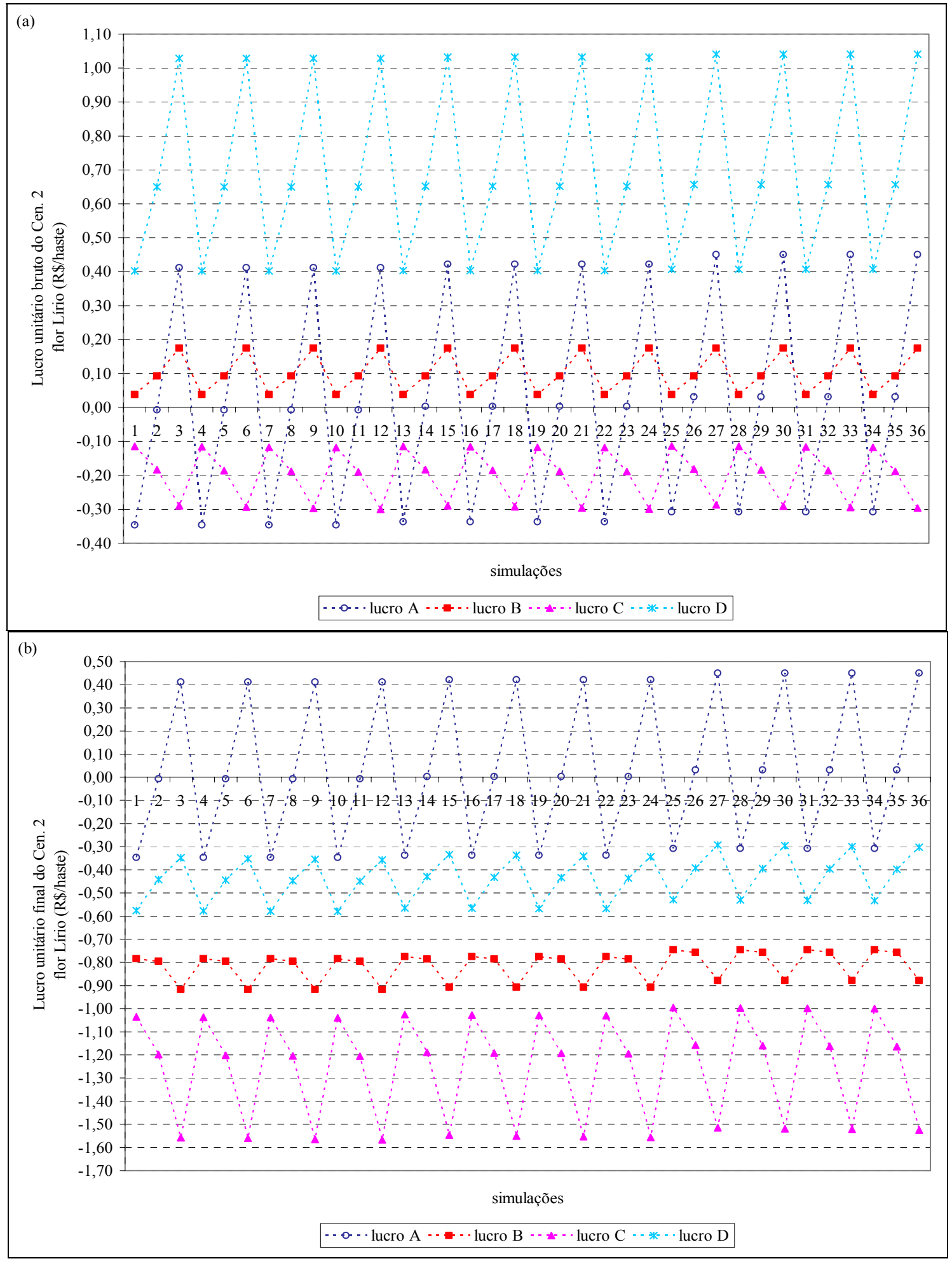

Figura 18 - Comparação dos lucros unitários de cada um dos processos para as produções bruta (a) e final (b) da flor lírio nas 36 simulações do Cenário 2 
Da mesma forma que ocorreu no cenário anterior, observou-se lucros positivos para flor gérbera 1 apenas para os maiores valores da taxa de câmbio, apesar de ter sofrido uma elevação média de $1 \%$ nos custos totais e de $5 \%$ na receita total em relação ao Cenário 1. Na Figura 19 são apresentados os custos, receitas e lucros totais para essa cadeia.

Nota-se que há relação direta entre aumento nos custos e valores da taxa de câmbio e de frete aéreo, e inversa em relação ao número de hastes por embalagem, ou seja, os maiores aumentos nos custos em relação ao cenário anterior relacionaram-se a menos hastes por caixa e a valores mais elevados de taxas de câmbio e de frete aéreo.

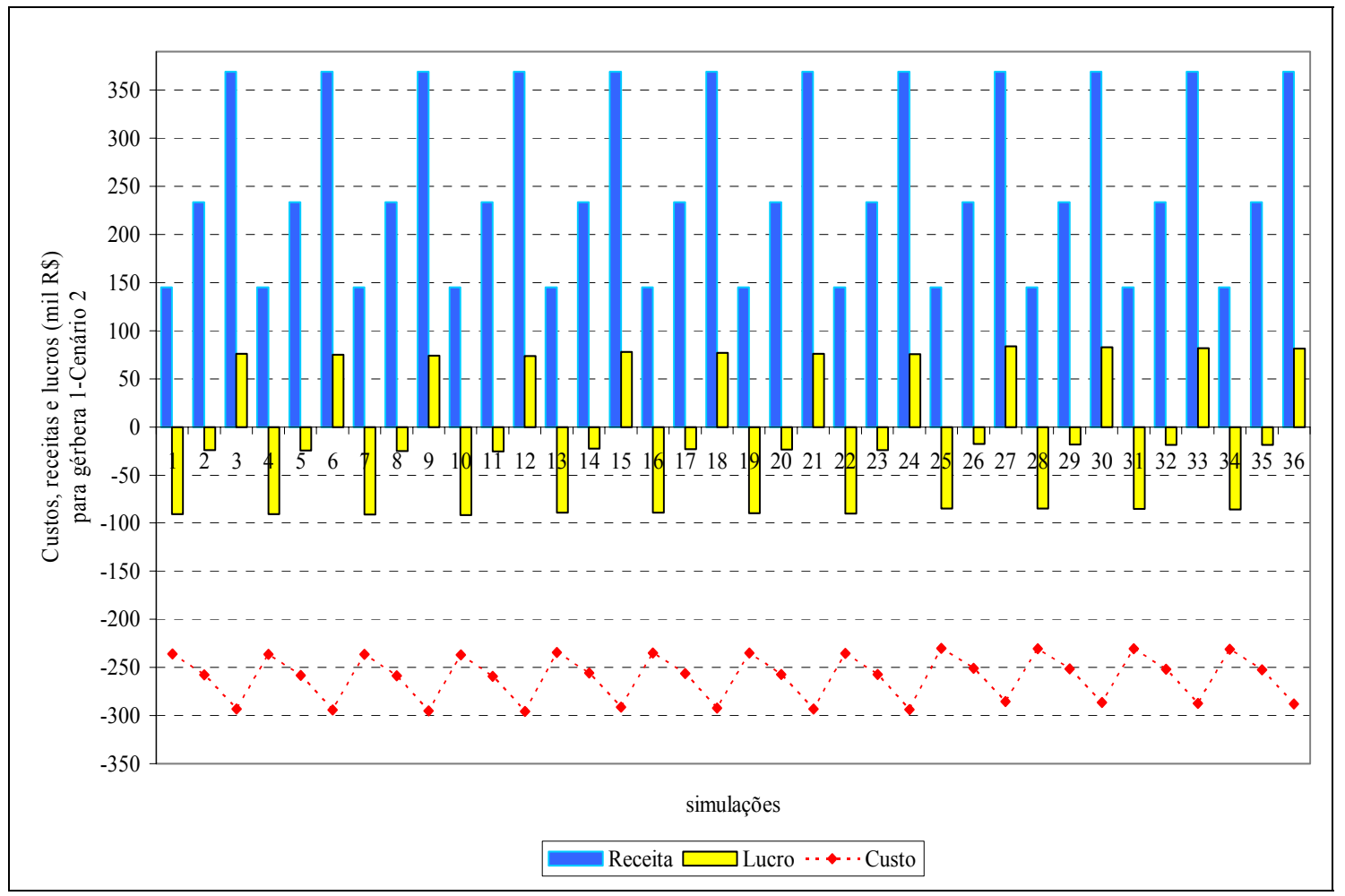

Figura 19 - Custos, receitas e lucros totais para a cadeia de gérbera 1 nas 36 simulações do Cenário 2

Para a flor gérbera 1 houve tendência de aumento no lucro unitário do processo de produção (A), conforme mostra a Figura 20(a), semelhante ao lírio, porém com amplitude menor de prejuízos em seu lucro bruto. 


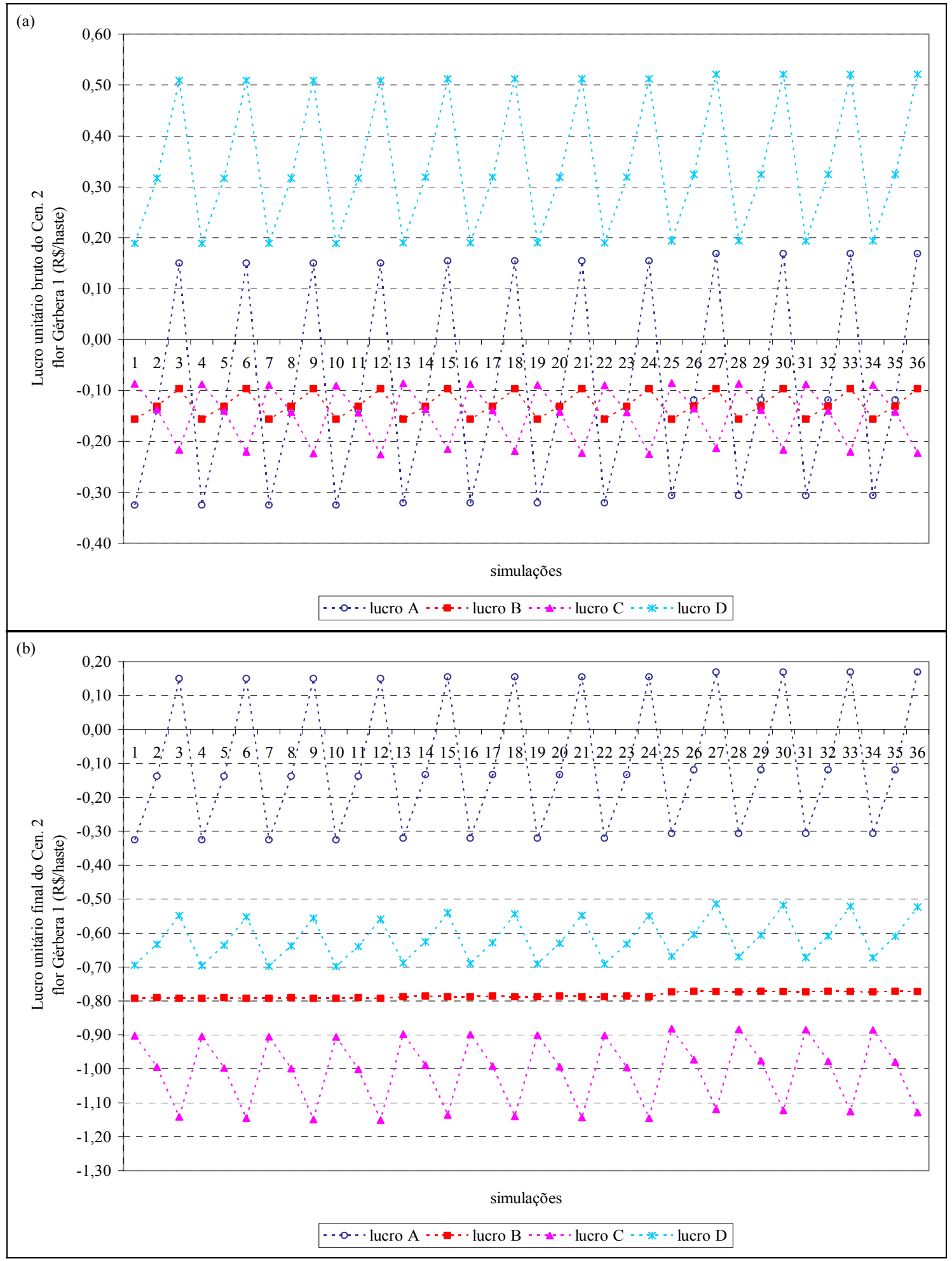

Figura 20 - Comparação dos lucros unitários de cada um dos processos para as produções bruta (a) e final (b) da flor gérbera 1 nas 36 simulações do Cenário 2 
Em relação ao processo de distribuição interna via modal rodoviário (B), observa-se que houve tendência de pequeno aumento nos seus prejuízos ao longo das simulações, semelhante à flor lírio. O processo (D) foi o único que apresentou valores positivos para o lucro bruto da flor gérbera 1 , com valores máximos em torno de $\mathrm{R} \$ 0,52$ por haste produzida nas simulações com a taxa de câmbio mais elevada.

Ao se analisar o lucro unitário final de cada um dos processos, mostrado na Figura 20(b), o processo de produção (A) alcançou os maiores valores nas simulações em que a taxa de câmbio atingiu seu maior valor ( $\mathrm{R} \$ 3,81$ por dólar), oscilando entre $\mathrm{R} \$$ 0,15 e R\$ 0,20 por haste. O processo de distribuição externa via modal rodoviário (D) sofreu maiores prejuízos em relação ao processo (A), atingindo valores de $\mathrm{R} \$ 0,70$ por haste nas simulações 1, 4 e 7 . O processo A foi o que mais sentiu os reflexos das menores perdas na produção, uma vez que foi contabilizada uma elevação média de 178\% do lucro final a partir da taxa de câmbio intermediária em relação ao Cenário 1. Para os outros processos houve redução nos prejuízos, da ordem de 4 a 7\%.

Com o acréscimo na receita em função da redução nas perdas na produção, a cadeia de gérbera 2 não apresentou prejuízos em todas as simulações. A Figura 21 apresenta os custos, receitas e lucros totais dessa flor. Os lucros totais positivos observados nas simulações com as menores taxas de câmbio foram muito pequenos. A partir das relações entre esses valores e os obtidos com a taxa de câmbio intermediária e a mais elevada, pôde-se constatar três patamares de lucro. À medida que se aumentou o número de hastes houve redução no efeito da taxa de câmbio. Para embalagens de gérbera 2 com 75 hastes observou-se que o lucro total na situação de maior valorização do real em relação ao dólar ( $\mathrm{R} \$ 3,81$ por dólar) representou entre 76 e 146 vezes o lucro da cadeia com câmbio mais desvalorizado (R\$ 1,50 por dólar). Nessa faixa houve elevação da relação em função do aumento no frete aéreo. Por outro lado, ao considerar 100 hastes, essa relação praticamente oscilou entre 18 e 20. 


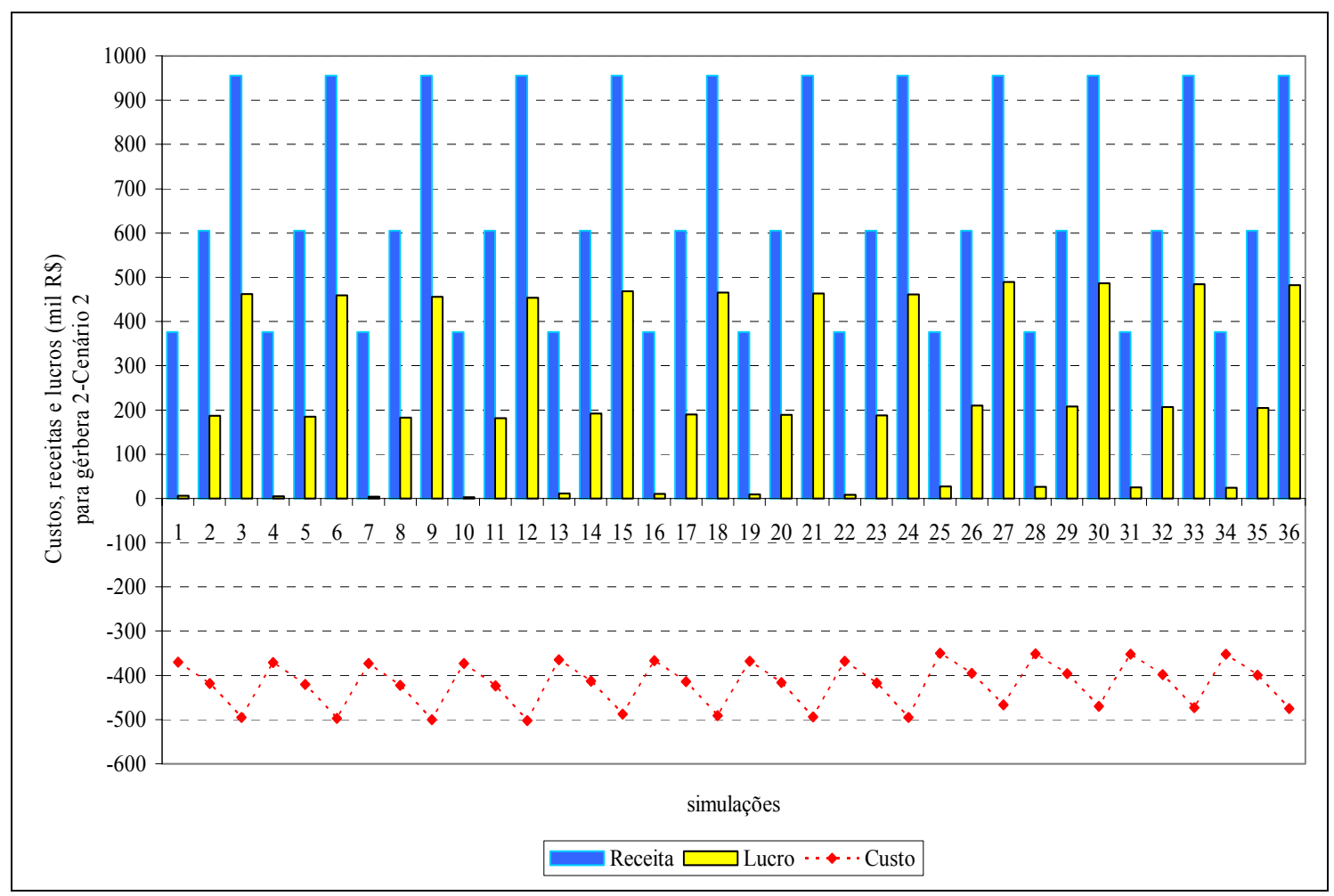

Figura 21 - Custos, receitas e lucros totais para a cadeia de gérbera 2 nas 36 simulações do Cenário 2

Os processos de produção (A) e de distribuição externa via modal rodoviário (D) apresentaram valores bem próximos de seus lucros unitários brutos nos pontos em que a taxa era de R\$ 3,81 por dólar, conforme se verifica na Figura 22(a). Esse desempenho foi bem distinto quando comparado às outras flores. Isso, provavelmente, ocorreu devido ao custo das embalagens possuir um peso bem maior no seu componente logístico quando comparado ao lírio e à gérbera 1 . O custo desse insumo está inversamente relacionado ao número de hastes por caixa. 


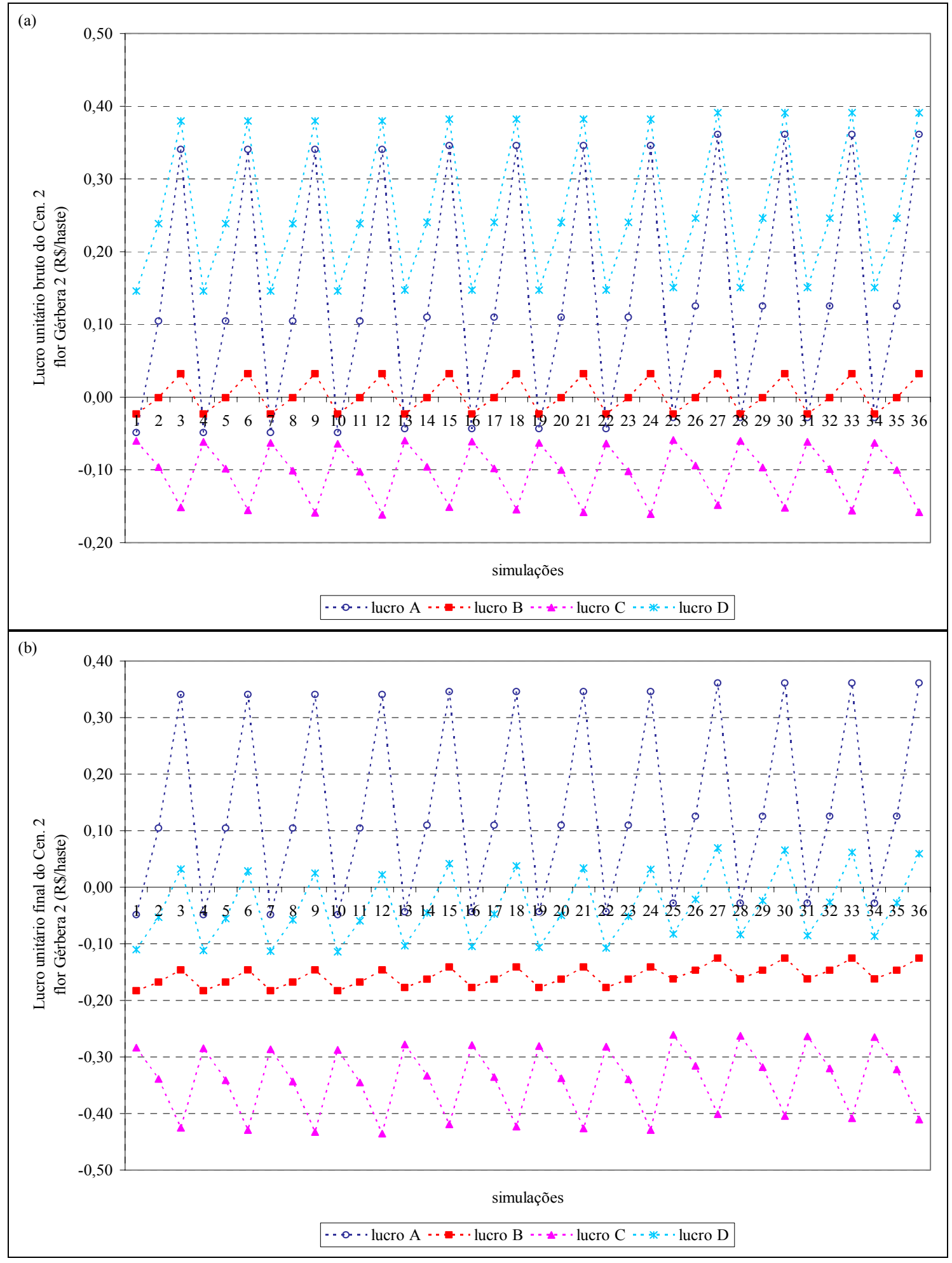

Figura 22 - Comparação dos lucros unitários de cada um dos processos para as produções bruta (a) e final (b) da flor gérbera 2 nas 36 simulações do Cenário 2 
Ao se analisar o seu lucro unitário final, mostrado na Figura 22(b), deve-se destacar que o processo de distribuição interna via modal rodoviário (B) apresentou redução de $5 \%$ nos prejuízos quando comparado ao cenário anterior. Nos processos de produção (A) e de distribuição externa via modal rodoviário (D) ocorreu elevação positiva desse lucro com o dólar a $\mathrm{R} \$ 3,81$, refletindo em aumentos de $4 \%$ e $31 \%$ em relação ao Cenário 1, respectivamente.

De maneira geral, a variação na taxa de câmbio tem-se refletido como um parâmetro determinante no desempenho de cada um dos processos da cadeia, a partir da análise dos lucros unitários bruto e final. Entre eles o mais suscetível foi o processo de produção (A) para todas as flores em ambos os cenários analisados, pois essas variáveis apresentaram as maiores amplitudes entre as simulações.

De acordo com Gollnow (2002), a Austrália tem procurado expandir suas exportações de flores de corte ao longo dos anos. Em 2000 seu valor total estimado representava menos de $1 \%$ do total comercializado internacionalmente, pois quase $90 \%$ de sua produção estavam direcionadas para o mercado interno. Para se garantir no mercado externo, seus produtores têm investido em qualidade das flores e serviços ao cliente. Dentre os fatores de infra-estrutura que determinam o sucesso dessa atividade estão mão-de-obra especializada, assistência técnica, capacidade adequada da câmara fria, instalações para desinfecção pós-colheita, transporte refrigerado para aeroporto e exportador confiável. As experiências de outros países, que também estão se inserindo no mercado mundial, são importantes para que o Brasil possa se balizar quanto às suas limitações e vantagens competitivas.

\subsubsection{Cenário 3: superávit logístico em todos os processos da cadeia}

Neste cenário foram adotadas perdas menores: $2 \%$ para o processo de produção (A), $0 \%$ para o processo de distribuição interna via modal rodoviário $(\mathrm{B}), 1 \%$ para $\mathrm{o}$ processo de distribuição externa via modal aéreo (C) e 1\% para o processo de distribuição externa via modal rodoviário (D), com superávit logístico na eficiência do ciclo do pedido, com acréscimo mínimo de investimento em todos os processos: $2 \%$ na 
produção e $1 \%$ nos demais. Para transportar as flores do produtor para a central de distribuição fez-se uso de veículo refrigerado. Nesse caso, foi utilizado contêiner ("câmara fria") no aeroporto, porém não foi feita fumigação ou pré-cooling nos aeroportos no Brasil ou EUA e não houve perda de carga no vôo. Na Figura 23 estão contidos os custos, receitas e lucros totais para a cadeia de lírio.

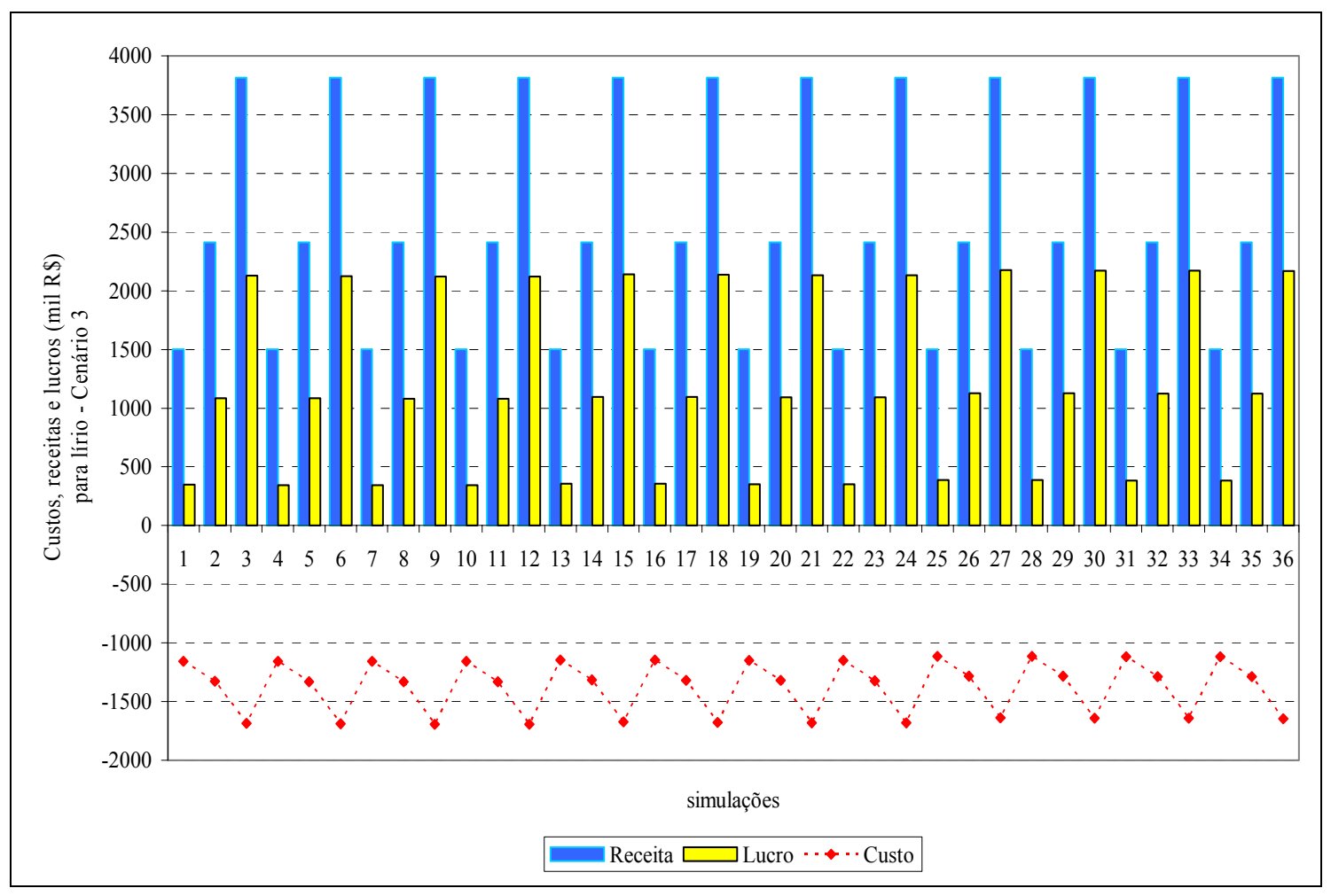

Figura 23 - Custos, receitas e lucros totais para a cadeia de lírio nas 36 simulações do Cenário 3

Nesse cenário verifica-se que, com a redução significativa de perdas em todos os processos da cadeia, houve elevação positiva do lucro total do lírio em todas as simulações. Por outro lado, ocorreu pequeno acréscimo no seu custo total, atingindo em relação ao cenário anterior redução máxima de $4 \%$ nas simulações com menores valores do câmbio e aumento máximo de 7\% nas simulações 27,33 e 36 . Estes pontos caracterizaram-se por ter os maiores valores da taxa câmbio e do número de hastes por caixa. Ao comparar os custos totais neste cenário, considerando maior valorização da 
moeda nacional em relação ao dólar, verificou-se uma elevação média de $46 \%$ em relação à primeira simulação e tendência de redução desses custos ao longo das simulações.

Na Figura 24 estão ilustrados os lucros unitários, bruto e final, de cada um dos processos da flor lírio. Neste caso verificou-se que todos os processos observaram melhoria no desempenho, com reflexo direto nos lucros brutos, conforme mostra a Figura 24(a). No processo de produção (A) os lucros unitários permaneceram positivos nos valores intermediário e mais elevado da taxa de câmbio. Apenas o processo de distribuição externa via modal aéreo (C) apresentou lucros brutos negativos, com magnitude menor do que o observado no cenário anterior. Por se caracterizar como um processo que não possui agregação de receita, reflete apenas os custos e falhas dessa etapa, relacionados ao sinal negativo. Como neste cenário observou-se melhoria das condições logísticas, todos os processos sofreram redução de seus prejuízos ou elevação de seu lucro em todas as simulações. Como houve investimento adicional em cada etapa para reduzir as falhas, a porcentagem de custos de cada processo foi realocada. 


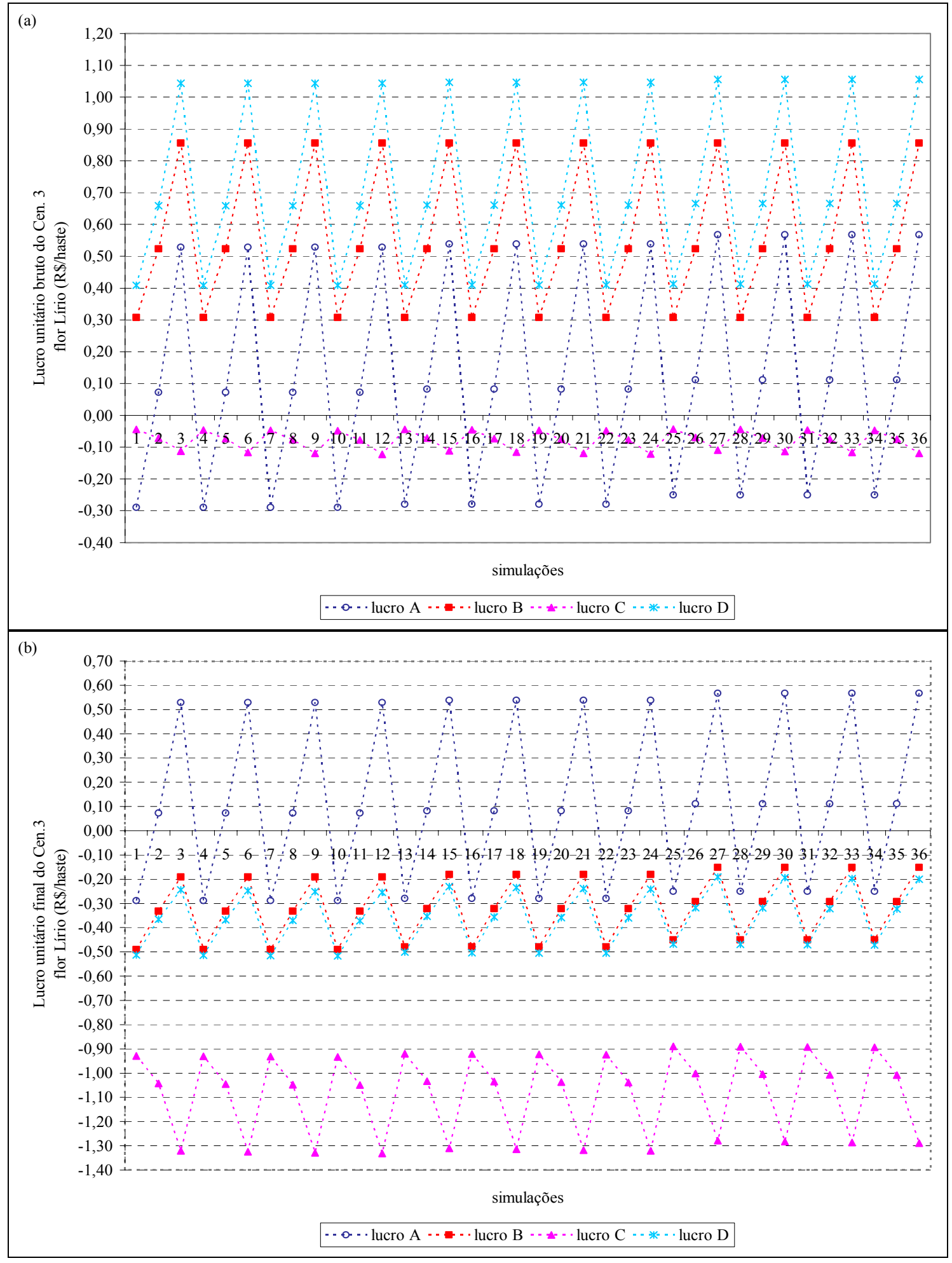

Figura 24 - Comparação dos lucros unitários de cada um dos processos para as produções bruta (a) e final (b) da flor lírio nas 36 simulações do Cenário 3 
Ao se analisar os lucros unitários finais, apresentados na Figura 24(b), com exceção do processo (A), os demais processos sofreram reduções nos prejuízos bem superiores do que as observadas nos cenários anteriores. O processo de distribuição interna via modal rodoviário (B) destacou-se como o que mais se beneficiou das vantagens logísticas, seguido pelo processo de produção (A), com diminuição média de $81 \%$ nos prejuízos e aumento de $27 \%$ nos lucros, respectivamente, na taxa de $\mathrm{R} \$ 3,81$ por dólar, em relação ao Cenário 2. Deve-se ressaltar que o processo de distribuição externa via modal aéreo também apresenta problemas sérios quanto à eficiência do ciclo do pedido, conforme expresso anteriormente na Tabela 4 e, esse cenário possibilitou uma redução média de $13 \%$ nos prejuízos desse processo em relação ao anterior. Os processos B e D apresentaram lucros finais com comportamentos e magnitudes muito semelhantes.

Na cadeia de gérbera 1 houve melhor reação à variação da taxa de câmbio neste cenário, viabilizando as exportações a partir do seu valor intermediário, cujos lucros foram positivos, como é mostrado na Figura 25 apresenta seus custos, receitas e lucros totais. De maneira geral, isso foi possível devido ao aumento da receita em $40 \%$ e pequena alteração nos seus custos totais em relação ao cenário anterior, provavelmente por haver compensação pela diminuição das perdas nesta situação. Conforme foi verificado na flor lírio, as simulações 27, 30, 33 e 36 sofreram as maiores elevações nos seus custos, 5\%, enquanto que as maiores reduções, 3\%, foram registradas nas simulações de menor taxa de câmbio. 


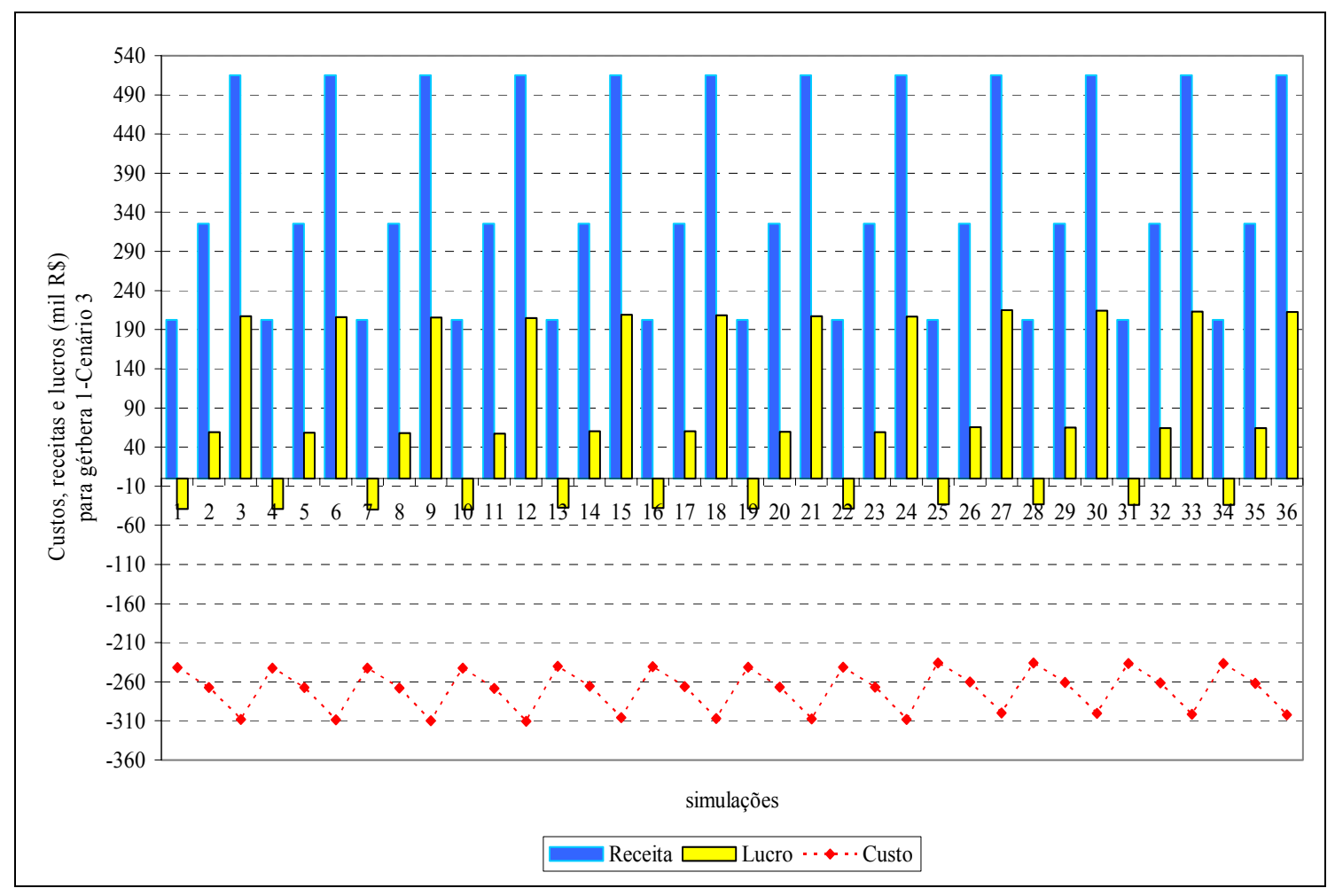

Figura 25 - Custos, receitas e lucros totais para a cadeia de gérbera 1 nas 36 simulações do Cenário 3

No caso da flor gérbera 1, os lucros unitários brutos de seus processos, representados na Figura 26(a), também refletiram a melhoria nas condições logísticas de exportação. Nesta cadeia os prejuízos do processo de produção (A) diminuíram, em média, $24 \%$ em relação ao cenário anterior, nos pontos em que o dólar assumiu R $\$ 1,50$ e R\$ 2,41 e, apesar disso, os lucros permaneceram negativos. Isso, provavelmente, ocorreu devido ao pequeno volume comercializado dessa flor, com menor flexibilidade das receitas e dos custos às oscilações econômicas, apesar de alguns custos na distribuição do produto serem rateados com outros produtores ou pagos proporcionalmente à quantidade exportada. O processo de distribuição interna via modal rodoviário (B) sofreu elevação significativa no seu lucro bruto em relação aos cenários anteriores, e apresentou valores positivos nas simulações com as taxas de câmbio a R\$ 2,41 e R\$ 3,81 por dólar para todas as simulações. 


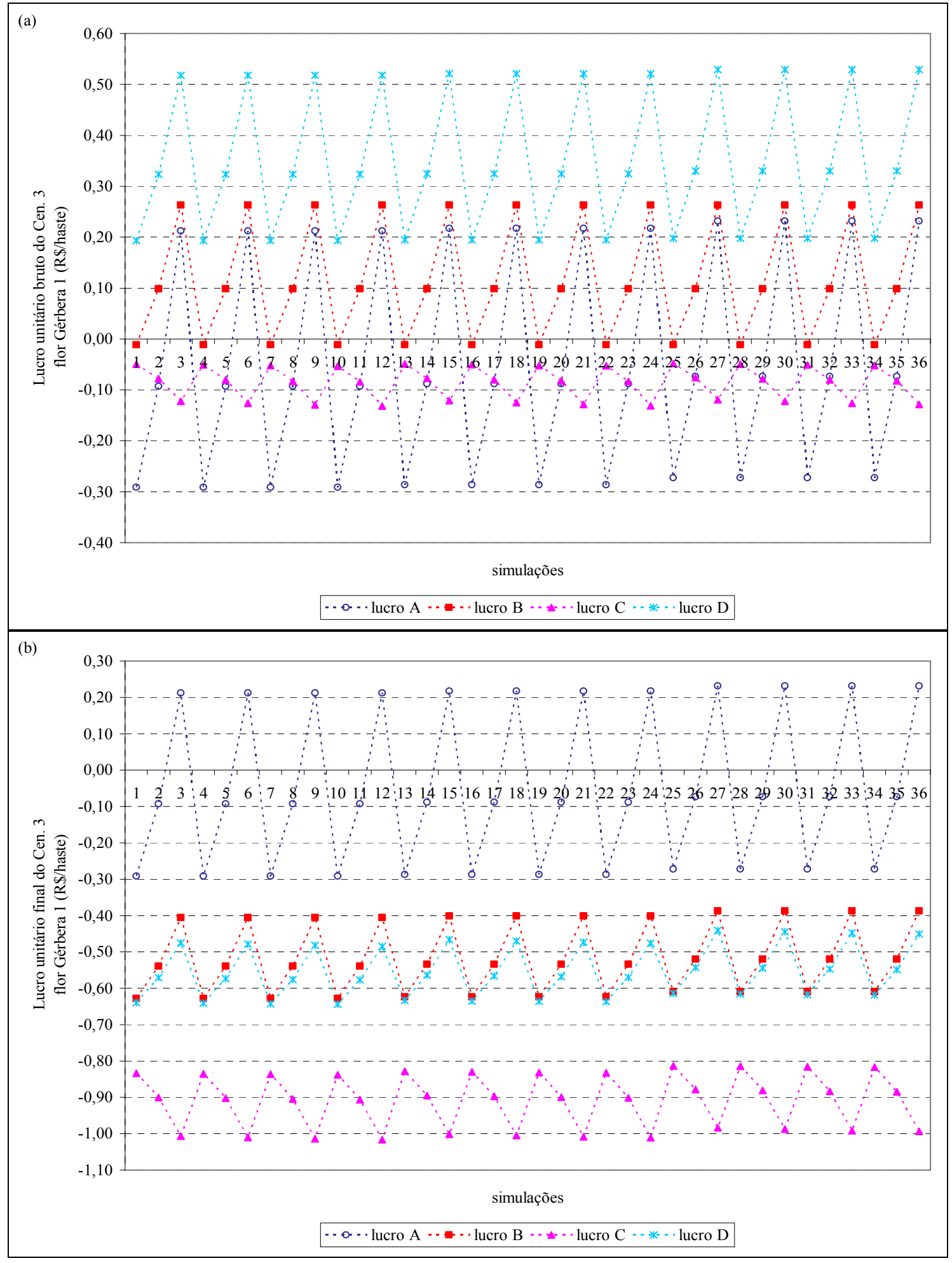

Figura 26 - Comparação dos lucros unitários de cada um dos processos para as produções bruta (a) e final (b) da flor gérbera 1 nas 36 simulações do Cenário 3 
Em relação aos lucros unitários finais dessa cadeia, expressos na Figura 26(b), o processo de produção (A) obteve melhor desempenho, a partir da melhoria das condições logísticas, apesar de seus valores positivos restringirem-se apenas à taxa de câmbio mais valorizada. Houve elevação maior com aumento do número de hastes para 100.

$\mathrm{Na}$ cadeia de gérbera 2 houve incremento significativo do lucro em todas simulações, com relação aos cenários anteriores, devido principalmente à elevação da receita. Seus custos, receitas e lucros totais estão representados na Figura 27. Conforme foi verificado nas outras duas cadeias, os custos totais tiveram pequeno aumento, com acréscimo maior de $8 \%$ na $27^{\mathrm{a}}$ simulação comparando com o cenário anterior.

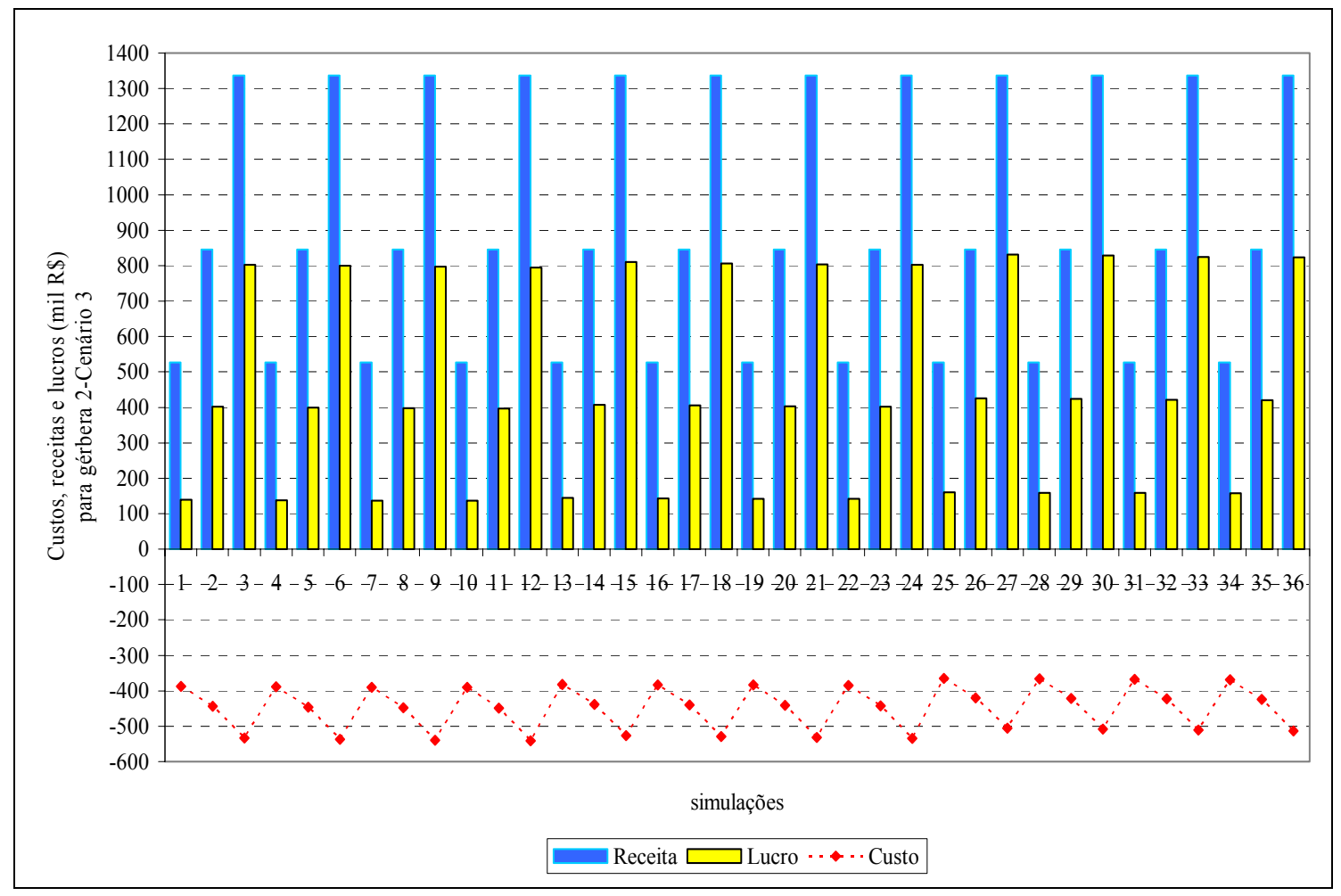

Figura 27 - Custos, receitas e lucros totais para a cadeia de gérbera 2 nas 36 simulações do Cenário 3 
Dentro do cenário atual o efeito da valorização do câmbio sobre o lucro total também se reduziu à medida que houve aumento no número de hastes por caixa, porém seu impacto foi bem menor ao observado no cenário anterior para as flores lírio e gérbera 1 . No caso de gérbera 2 , ao se estabelecer a razão entre os lucros da cadeia para os câmbios mais elevado e o mais baixo, os valores médios obtidos foram de aproximadamente 5,80 para 75 hastes reduzindo-se para 5,20 para 100 hastes. Para as outras cadeias essa relação ficou próxima de 6,20 e de 5,20 para 75 hastes e de 5,60 e de $-6,40$ para 100 hastes, respectivamente, para lírio e gérbera 1.

Apesar do frete aéreo representar um dos principais custos do processo de distribuição externa via modal aéreo (C) - em torno de 50\% - sua representatividade variou conforme o cenário e o tipo de flor. Verificou-se que a participação desse insumo no custo logístico total oscilou entre 3 e 15\%. O efeito das alterações no valor do frete aéreo ao longo das simulações foi pequeno em relação aos outros fatores analisados. Nos cenários apresentados, o impacto da mudança dessa variável foi mascarado pela taxa de câmbio e minimizado pelo aumento no volume exportado por caixa, considerando as flores estudadas. De acordo com Confederação Nacional da Indústria (2002), os três maiores entraves à exportação estão relacionados à burocracia alfandegária, custos portuários e custo do frete internacional.

A cadeia da flor gérbera 2 também apresentou lucros unitários brutos mais elevados quando comparados aos cenários anteriores, conforme mostra a Figura 28(a). Nota-se que o processo de distribuição externa via modal rodoviário (D) manteve lucro positivo ao longo das 36 simulações, com média de R $\$ 0,30$ por haste. O processo de distribuição interna via modal rodoviário (B) seguiu a mesma tendência do processo (D). 


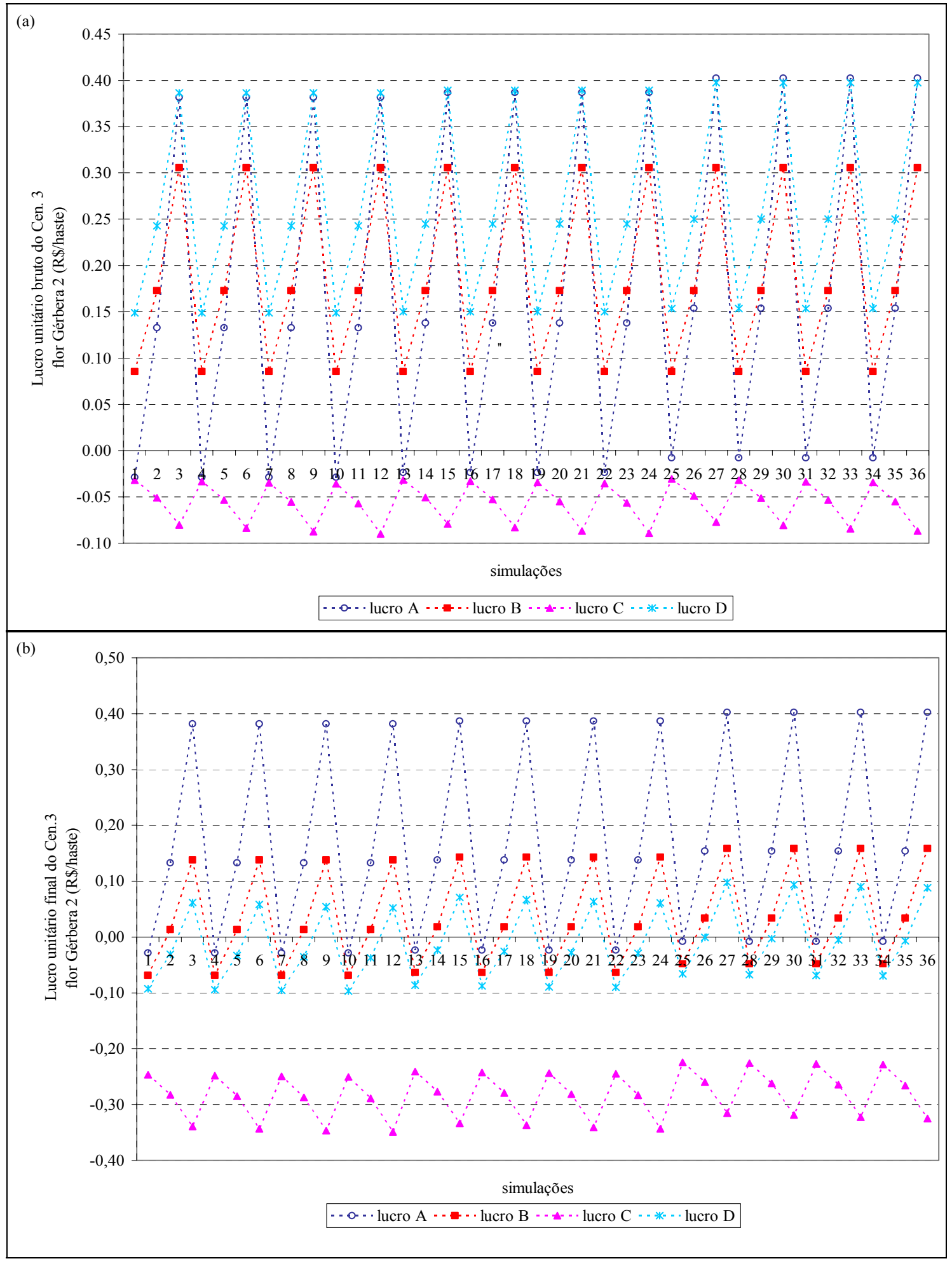

Figura 28 - Comparação dos lucros unitários de cada um dos processos para as produções bruta (a) e final (b) da flor gérbera 2 nas 36 simulações do Cenário 3 
Em todos os cenários esses lucros tiveram pequena tendência de aumento com a elevação no número de hastes vendidas, apesar do processo $\mathrm{B}$ ter apresentado comportamento pior nos anteriores, ou seja, lucros com amplitudes menores entre as simulações, porém com prejuízos em grande parte delas. Ao compará-lo com os cenários anteriores, o processo de produção (A) sofreu acréscimos decrescentes no lucro unitário bruto ao longo das simulações para cada um dos maiores valores de taxas de câmbio, com influência mais acentuada nos pontos com maior número de hastes por embalagem. Em relação ao Cenário 2, por exemplo, esses lucros diminuíram, em média, 12\% ao considerar o dólar a R $\$ 3,81$. Nos pontos em que ocorreu a menor valorização do real (R\$ 1,50 por dólar) foram registradas reduções nos prejuízos da ordem de 53\% com utilização de embalagens com 75 hastes, e de $80 \%$ para 100 hastes.

Em termos do lucro unitário final da flor gérbera 2, apresentado na Figura 28(b), deve-se destacar que houve diminuição nos prejuízos dos lucros de todos os processos, em maior dimensão do que a observada nas cadeias das outras flores analisadas, uma vez que apenas o processo de distribuição externa via modal aéreo (C) apresentou lucros negativos em todas as simulações. Em todos os processos houve diferenciação nos patamares dos lucros com o aumento no número de hastes, acarretando em maior elevação, principalmente nas simulações que consideraram a adoção da comercialização de 100 hastes por caixa, seguindo a mesma tendência dos lucros brutos.

Observa-se que a flor lírio apresentou os menores prejuízos, por influência da taxa de câmbio, em função, principalmente, do seu maior valor transacionado em relação às flores gérbera 1 e 2 . Outro fator que também contribuiu para esse aumento no lucro total foi a elevação do número de hastes por caixa ao longo das simulações, atingindo seu pico na $36^{\mathrm{a}}$ simulação, para todas as flores. Em todos os cenários os maiores custos e receitas têm se mantido para as mesmas flores, em ordem decrescente, lírio, gérbera 2 e gérbera 1.

As alterações ocorridas neste cenário com a introdução de componentes logísticos que auxiliaram na coordenação da cadeia reforçam a necessidade de reavaliação dos procedimentos utilizados para exportação a fim de otimizar os recursos empregados na exportação do produto brasileiro. É o caso, por exemplo, da melhoria das 
atividades executadas no processo de distribuição interna via modal rodoviário (B), refletidas na diminuição do seu lead time. Além dos fatores considerados, há outros também complexos, relatados por Florabrasilis (2002), que devem ser trabalhados conjuntamente, como é o caso de idoneidade do importador. De maneira geral, a falta de confiança entre os parceiros pode se tornar um gargalo para que a cadeia, limitando a sua expansão no mercado externo.

As experiências de outros países podem ser relevantes para que se identifiquem pontos fracos em comum e se tome conhecimento de como os problemas foram resolvidos ou amenizados. $\mathrm{Na}$ Holanda, por exemplo, onde a competitividade no mercado de flores é bastante acentuada, estudos logísticos têm sido conduzidos para tornar a cadeia mais responsiva, visando melhorar a qualidade do produto e do serviço ao cliente.

Num estudo recente, conforme Engelbart e Rijswijk (2001b), foi formulado um modelo logístico para medir e ajustar o desempenho da cadeia, tomando como parâmetro principal a redução do lead time da cadeia. Esse projeto tornou-se viável, pois foram estabelecidos relacionamentos de longo prazo entre os agentes. Essa confiança mútua entre os parceiros foi pré-requisito para relação vertical na cadeia, despertando o interesse comum em melhorar a competitividade da cadeia.

A partir da ação integrada entre Veiling, operador logístico, exportador e universidades, institutos de pesquisa e consultores foi desenvolvido um modelo agrologístico (ALM - Agro Logistics Model) através de projeto piloto em Plantania, cujas produções de plantas em vaso eram destinadas à Alemanha e ao varejo, descrito em Engelbart e Rijswijk (2001a). O Veiling constituiu-se num dos agentes envolvidos de maior importância, pois representa os produtores e agrega a informações logísticas e as inovações tecnológicas. Com base em indicadores chave, conforme Snels (2003), foram delineados os melhores cenários logísticos de atuação dessas cadeias, com os quais foi possível reduzir o lead time de 27 para 8 horas. 


\subsubsection{Cenário 4: déficit logístico na cadeia, com falhas no processo de distribuição interna via modal rodoviário}

Neste cenário foram consideradas perdas de $10 \%$ para o processo de produção (A), 1\% para o processo de distribuição interna via modal rodoviário $(\mathrm{B}), 2 \%$ para $\mathrm{o}$ processo de distribuição externa via modal aéreo (C) e 3\% para o processo de distribuição externa via modal rodoviário (D), com déficit logístico na eficiência do ciclo do pedido e sem refrigeração do veículo que transportou as flores do produtor para a central de distribuição. Nesse caso, não foi utilizado contêiner ("câmara fria") no aeroporto. Supôs-se que o exportador detectou problemas na carga e optou por realizar fumigação antes da mercadoria ser enviada ao aeroporto no Brasil em 10 embarques no ano num total de $15 \%$ do volume embarcado. Como se trata de um insumo mais relacionado ao processo produtivo, pode acarretar num entrave para a cadeia, em função de elevação nos seus custos e na redução da qualidade das flores exportadas. Na Figura 29 são apresentados os custos, receitas e lucros totais para a cadeia de lírio.

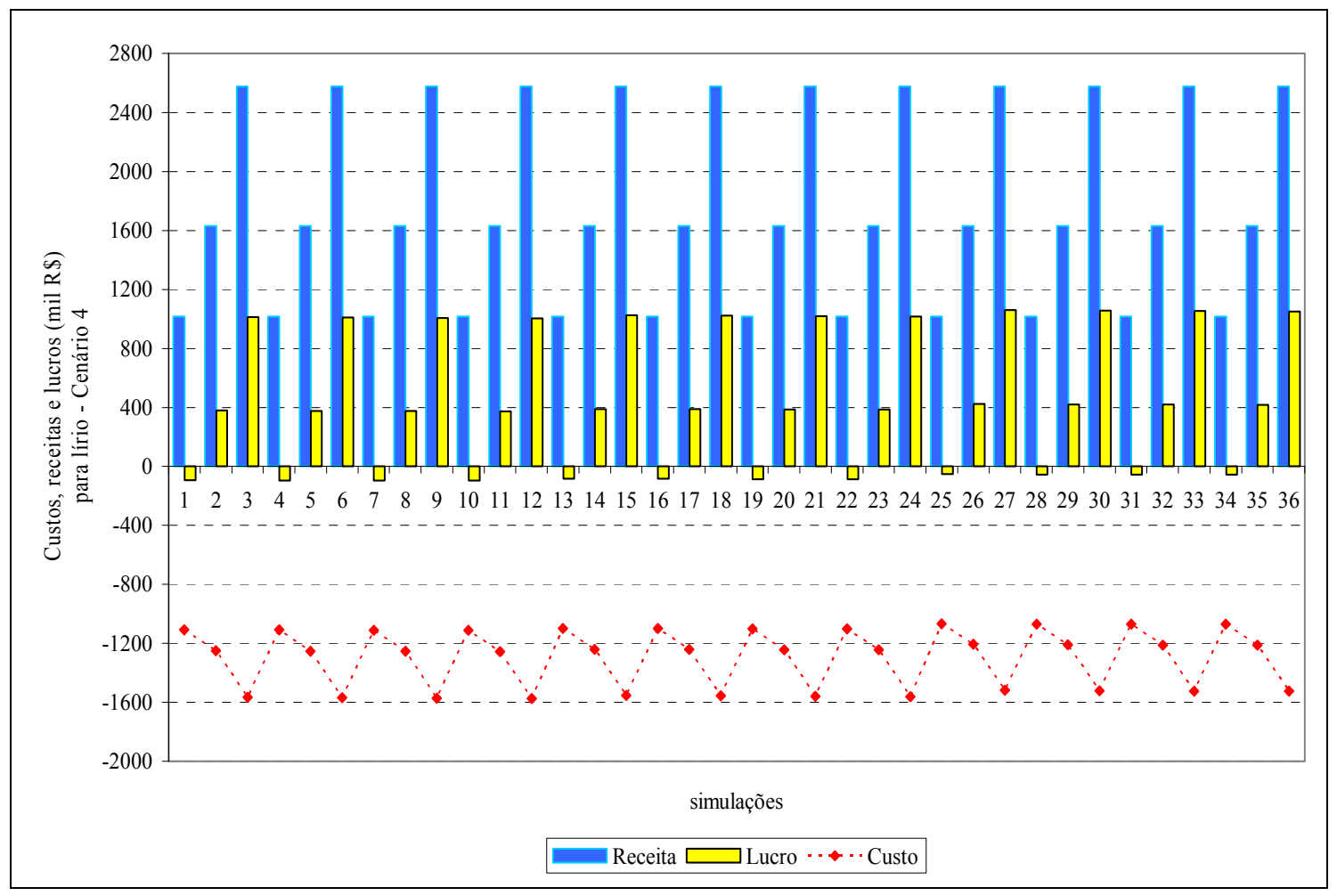

Figura 29 - Custos, receitas e lucros totais para a cadeia de lírio nas 36 simulações do Cenário 4 
Ao comparar este cenário com o anterior, observa-se que o custo total do lírio diminuiu $6 \%$ e a receita total caiu 32\%, em média. Nas análises dos cenários anteriores verificou-se crescente aumento nos custos, o que não foi constatado no atual. Como houve redução mais acentuada das hastes comercializadas devido às maiores perdas nos processos e ineficiências na cadeia, e menor investimento no processo de produção, a elevação do lucro total ficou comprometida. Seus valores foram menores do que os obtidos no Cenário 1. Verificou-se que apenas nos pontos com taxas de câmbio intermediária e mais elevada não houve prejuízos para a cadeia como um todo. Ao longo das simulações com maiores valores de taxa de câmbio o custo total variou bastante, atingindo pico de $42 \%$ de aumento na $12^{\mathrm{a}}$ em relação à primeira simulação. Como as fumigações são custeadas por caixa, ou seja, ocorreu compensação nos custos com o maior volume de flores por embalagem.

Os lucros unitários brutos de cada um dos processos de produção da flor lírio são mostrados na Figura 30(a). O processo de distribuição externa via modal rodoviário (D) foi o único que manteve lucros positivos em todas as simulações. Neste caso pressupôsse que existiram falhas no processo de produção (A), levando a perdas de 10\%, semelhante ao observado no Cenário 1. Considerou-se que não foi efetuado controle fitossanitário eficiente na propriedade rural neste caso; desta forma, o processo seguinte (B) elevou seus custos para controlar os insetos, afetando diretamente o lucro unitário dessa etapa. 


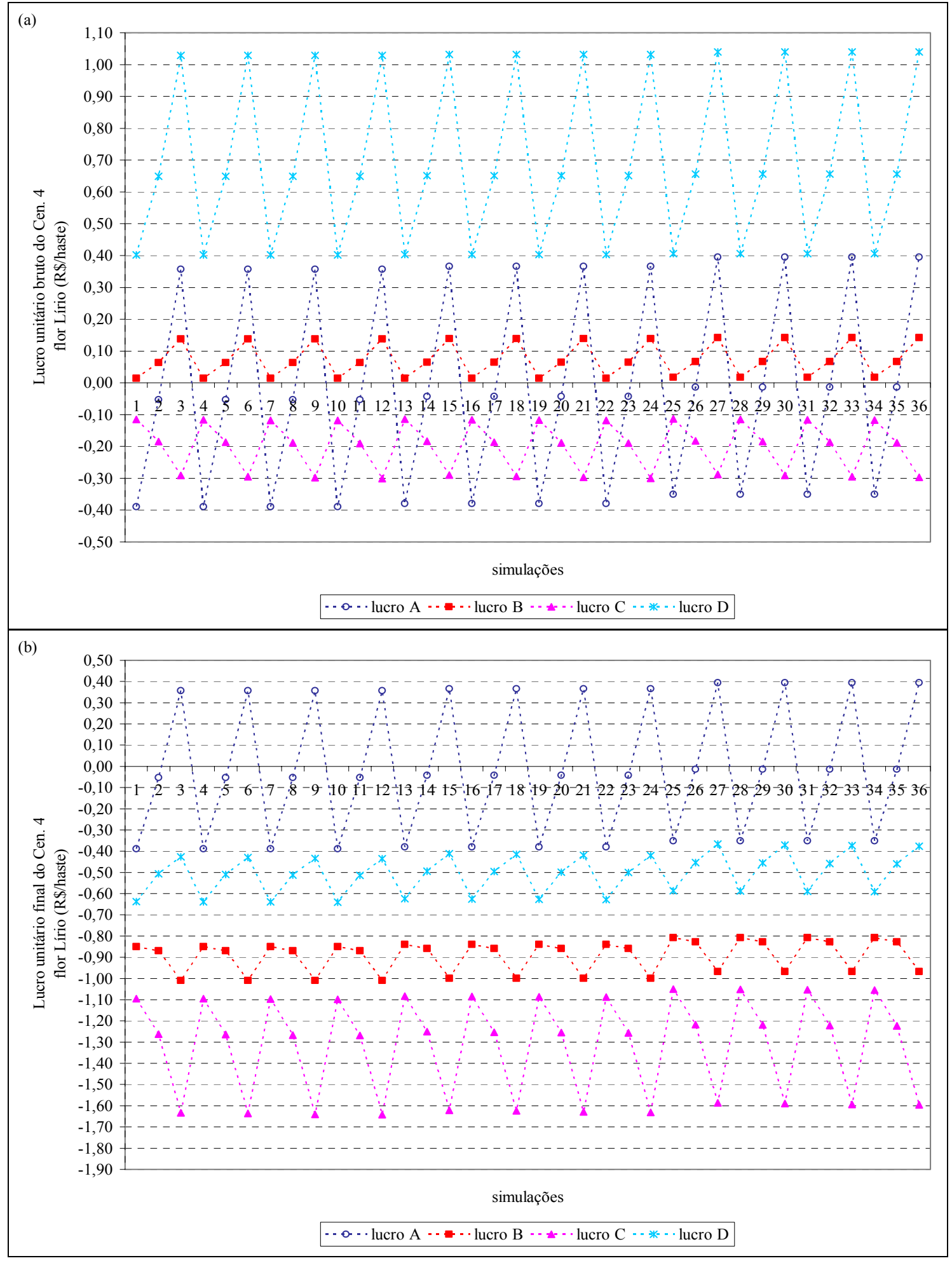

Figura 30 - Comparação dos lucros unitários de cada um dos processos para as produções bruta (a) e final (b) da flor lírio nas 36 simulações do Cenário 4 
Como a fumigação pode ser um dos componentes do processo de distribuição interna via modal rodoviário (B), normalmente executados pelo exportador ou pela cooperativa que intermedeia a exportação, seu lucro unitário bruto foi muito afetado por esse procedimento adicional. Esse processo sofreu redução média de $34 \%$ e de $89 \%$ em relação ao primeiro e terceiro cenários, respectivamente, com pequena variação entre as simulações. Não houve alteração no lucro com variação no valor do frete aéreo, pois esse elemento não compõe os custos desse insumo de produção. O processo de distribuição externa via modal aéreo (C) também não foi afetado, pois não houve descarte da carga embarcada após a vistoria do Ministério de Agricultura dos EUA. Apesar dos lucros brutos dos processos (C) e (D) não terem sido afetados diretamente pelas falhas dos processos anteriores, seu lucro unitário final se alterou.

Ao analisar os lucros unitários finais constatou-se que todos os processos apresentaram valores negativos, com exceção do processo A nos pontos de maior valor de taxa de câmbio. No processo de distribuição externa via modal aéreo $(\mathrm{C})$ observou-se o mesmo comportamento dos dois cenários iniciais. Quando comparado ao cenário anterior, verificou-se que ocorreu maior amplitude de variação de seus prejuízos ao longo das simulações.

A cadeia de gérbera 1 tem apresentado os piores resultados em relação às variações da taxa de câmbio. A Figura 31 apresenta os custos, receitas e lucros totais dessa cadeia para o Cenário 4. Os prejuízos para a cadeia como um todo foram mais elevados neste cenário, quando comparado aos anteriores. Isso é conseqüência maior da redução na receita total em $32 \%$ e não devido exclusivamente aos custos, que sofreram redução média de $4 \%$ em relação ao cenário anterior. Apenas na $27^{\mathrm{a}}$ simulação, ponto em que a taxa de câmbio atingiu seu maior valor e maior número de hastes por embalagem, houve acréscimo maior no lucro da cadeia. 


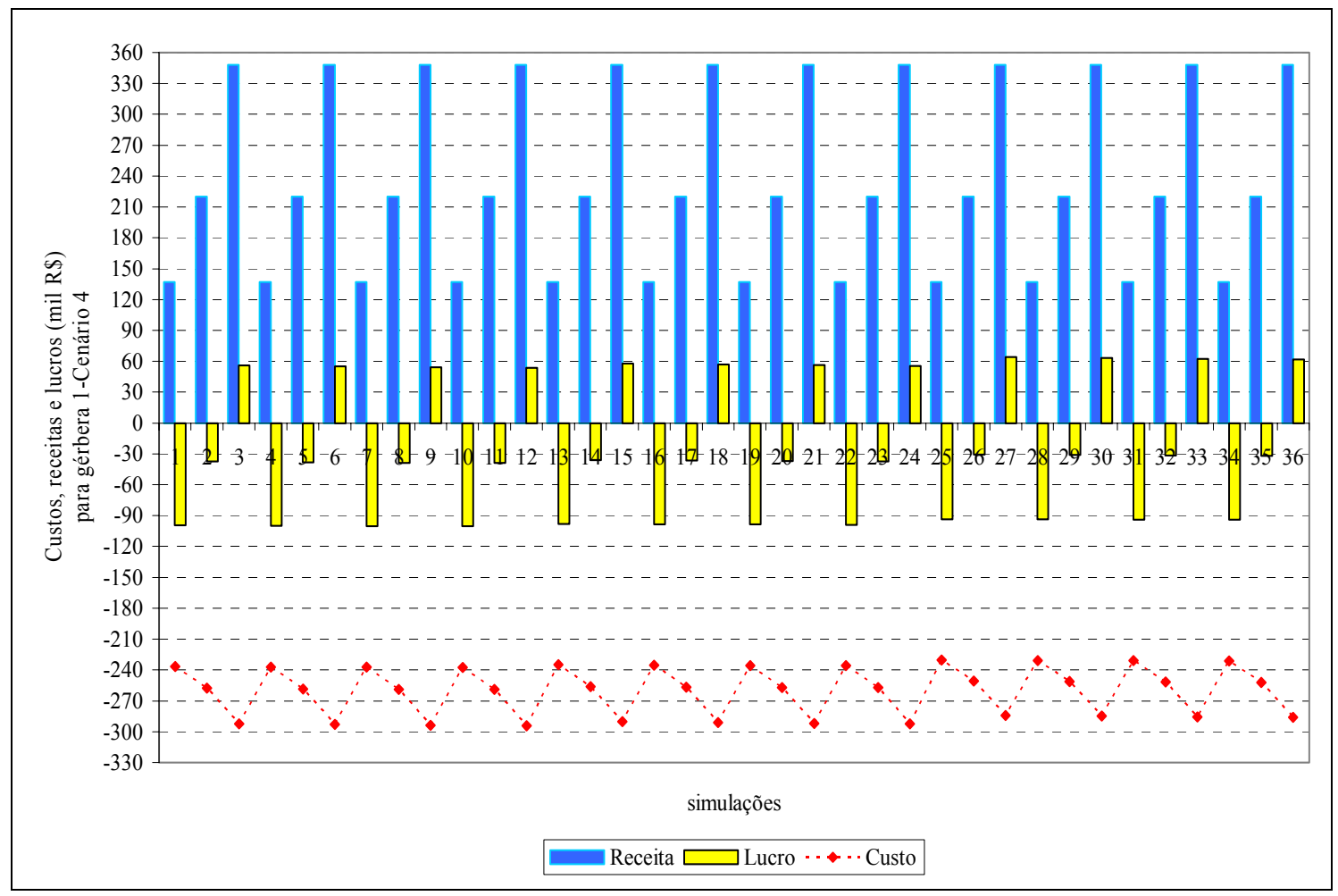

Figura 31 - Custos, receitas e lucros totais para a cadeia de gérbera 1 nas 36 simulações do Cenário 4

Na Figura 32 são apresentados os lucros unitários brutos e finais da cadeia da flor gérbera 1. O processo de distribuição externa via modal rodoviário (D) também foi o único que manteve lucros brutos positivos em todas as simulações, semelhante ao obtido no Cenário 1 , oscilando entre $\mathrm{R} \$ 0,19$ e $\mathrm{R} \$ 0,52$. Nota-se que o processo de distribuição interna via modal rodoviário (B) foi o mais afetado em termos da produção bruta, cujo lucro foi reduzido em $19 \%$ e 207\%, em média, em relação aos Cenários 1 e 3, respectivamente, quando um dólar equivalia a $\mathrm{R} \$ 2,41$ e $\mathrm{R} \$ 3,81$. Seus maiores prejuízos foram constatados nos pontos em que havia menor valorização do real em relação ao dólar e com utilização de menor número de hastes por caixa. Esses dados indicam que a competitividade dessa cadeia foi bastante comprometida devido às falhas nesse processo. Neste cenário o processo de produção (A) apresentou as mesmas características especificadas para o Cenário 1 e, portanto, os mesmos problemas já discutidos anteriormente. 


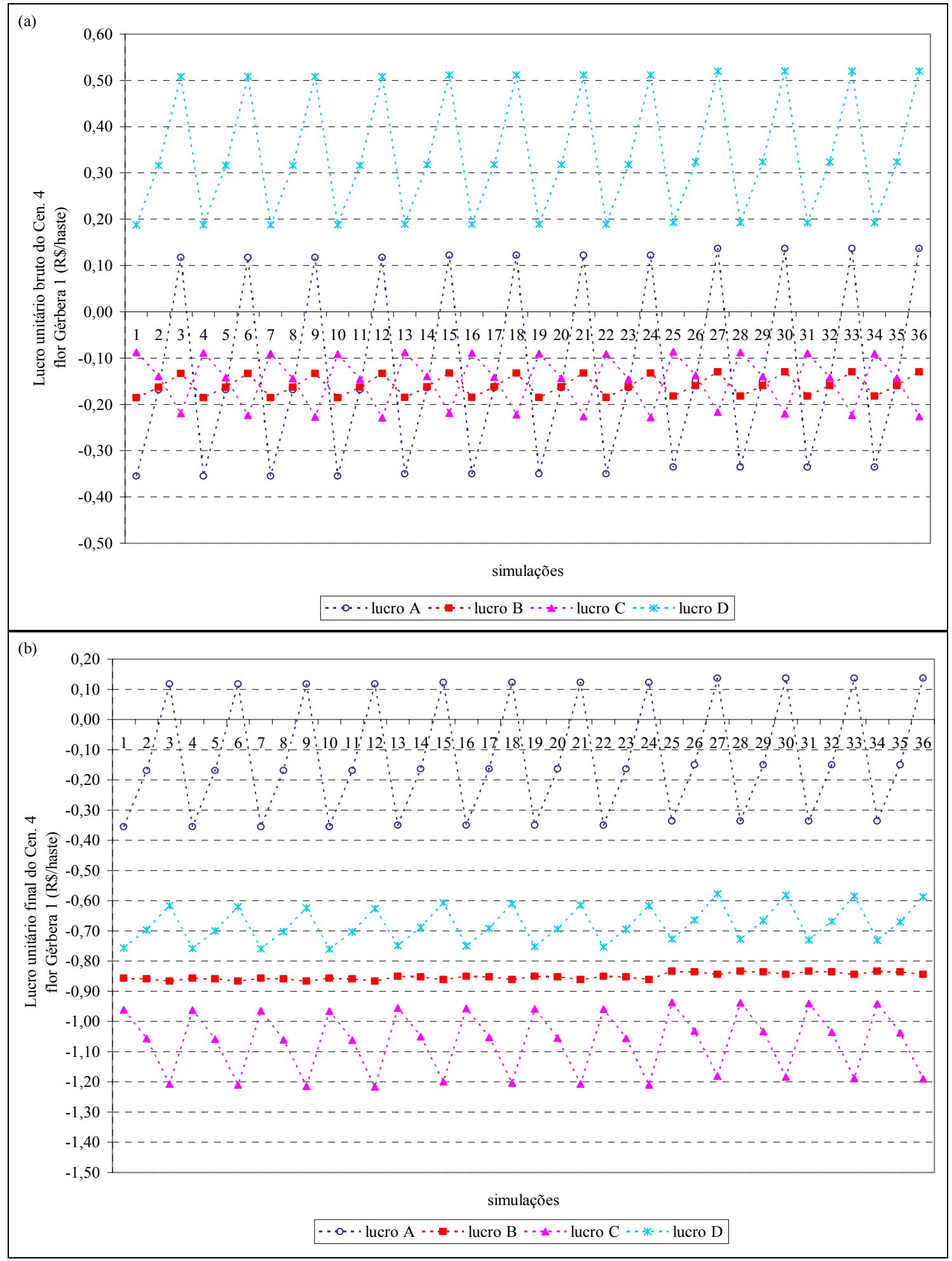

Figura 32 - Comparação dos lucros unitários de cada um dos processos para as produções bruta (a) e final (b) da flor gérbera 1 nas 36 simulações do Cenário 4 
$\mathrm{Na}$ análise dos lucros unitários finais dessa flor, mostrados na Figura 32(b), com exceção do processo (A), observa-se que os demais não apresentaram lucros com valores positivos. Apesar de terem sido registrados problemas no processo (B), repercutindo diretamente em perdas maiores nessa etapa, os processos seguintes também foram prejudicados, porém em menor escala. Houve redução média nos lucros finais de $17 \%$ e $23 \%$, respectivamente para os processos (C) e (D) em relação ao cenário anterior. Apesar de haver diferenças na estrutura de seus insumos, os maiores impactos desses prejuízos ocorreram nas mesmas simulações em cada uma das etapas. Ambos processos foram mais suscetíveis ao menor número de hastes por embalagem e ao menor valor da taxa de câmbio.

Conforme observado nas outras cadeias, a de gérbera 2 também reduziu bastante a sua eficiência neste cenário com relação ao anterior. A Figura 33 mostra os custos, receitas e lucros totais dessa cadeia. Os prejuízos no lucro total persistiram em todas as simulações do nível mais baixo de taxa de câmbio até atingir a $22^{\mathrm{a}}$ simulação, com o maior valor de frete aéreo e 80 hastes por caixa. Neste caso os custos sofreram diminuição média de $6 \%$ em relação ao cenário anterior, semelhante ao observado na cadeia de lírio. 


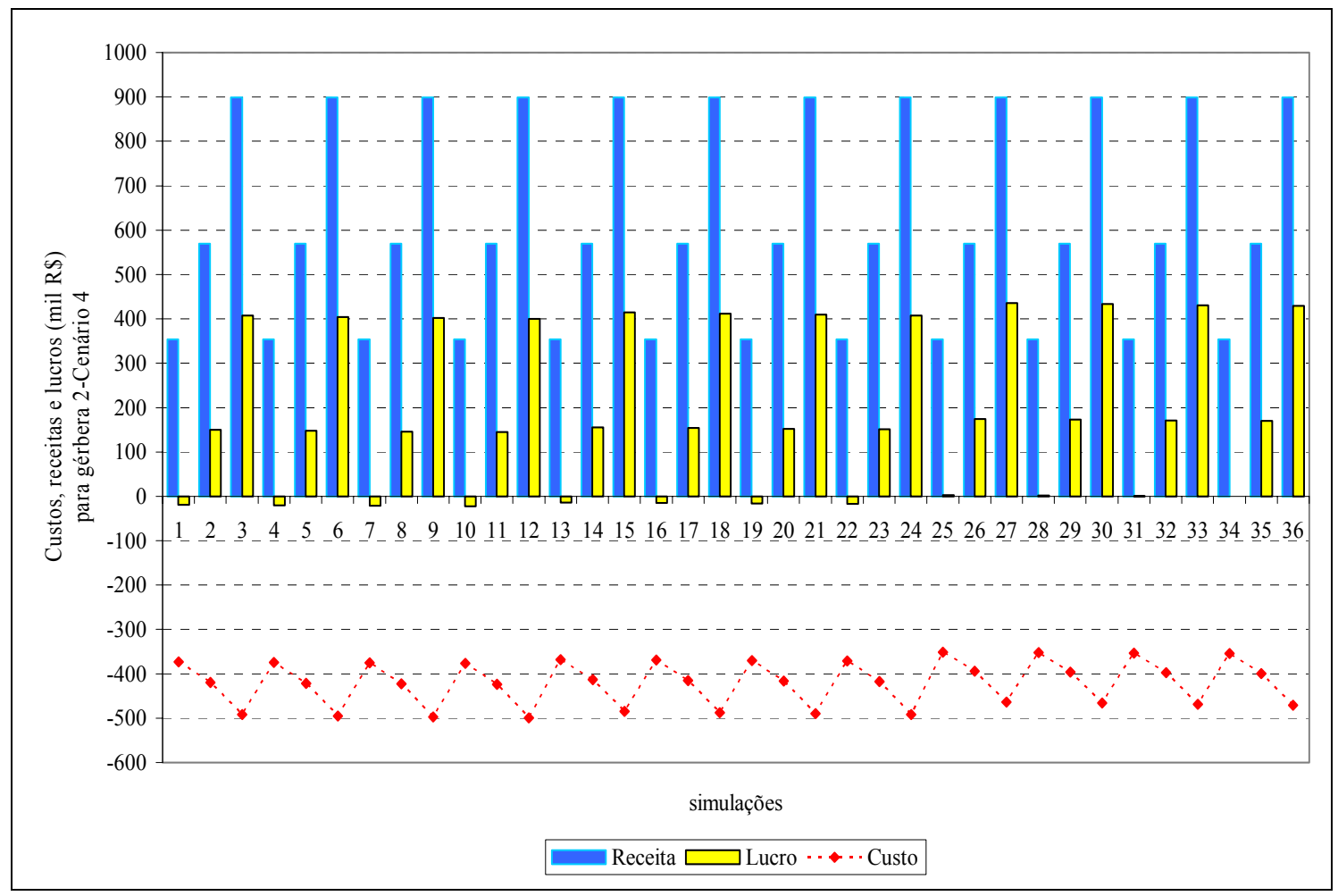

Figura 33 - Custos, receitas e lucros totais para a cadeia de gérbera 2 nas 36 simulações do Cenário 4

Ao analisar o impacto do lucro total da cadeia nas situações com maior e menor valorização do real em relação ao dólar, detectou-se também neste cenário a influência mais acentuada da alteração no número de hastes e menos nos valores de frete aéreo na redução do efeito da elevação da taxa de câmbio ao longo das simulações. Neste caso as amplitudes das relações entre os lucros foram superiores ao observado no cenário anterior para lírio e gérbera 2 e inferiores para gérbera 1 .

Para o lírio a proporção entre os lucros com maior e menor valores do câmbio ficou em torno de 10,60 para 75 hastes reduzindo para 19,30 para 100 hastes. Para gérbera 1 o efeito foi bem menor, partindo de 0,60 para 75 hastes e atingindo 0,70 , em média, para 100 hastes. A relação para a gérbera 2 ficou num patamar inferior em relação às outras duas flores, em torno de 19,50 para menor volume por caixa, atingindo 661 para o maior, diferenciando-a das demais. Isso ocorreu, pois nessa cadeia havia prejuízo nos pontos em que o real estava menos valorizado para 75 e 100 hastes. Apesar 
dos problemas deste cenário, ao utilizar 100 hastes por caixa houve compensação no lucro, tornando-se positivo a partir dos menores valores do câmbio. Com o dólar a R\$ 3,81 o lucro atingiu valores, em média, 661 superiores ao observado com o câmbio a R\$ 1,50 .

Nesta cadeia o comportamento diferenciado em relação às demais flores também se refletiu nos lucros unitários, bruto e final, de cada um dos processos, mostrados na Figura 34. Neste cenário considerou-se que houve falhas no processo de produção (A), levando a perdas de $10 \%$, semelhante ao observado no Cenário 1 . A flor gérbera 2 recuperou-se mais rapidamente do que lírio e gérbera 1, atingindo lucros positivos a partir do valor intermediário da taxa de câmbio. 


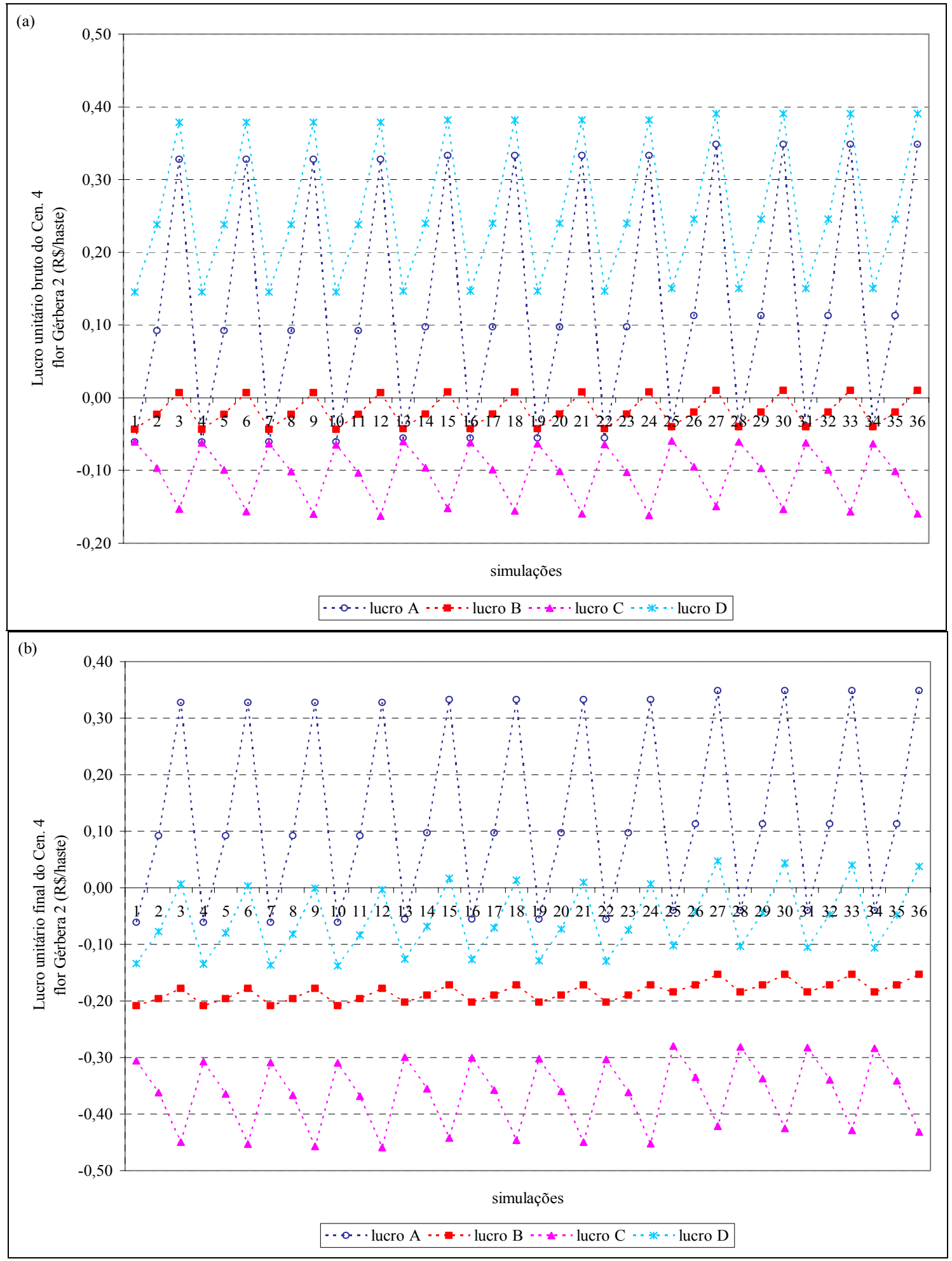

Figura 34 - Comparação dos lucros unitários de cada um dos processos para as produções bruta (a) e final (b) da flor gérbera 2 nas 36 simulações do Cenário 4 
Ao analisar a distribuição interna via modal rodoviário (B), pôde-se observar que foi bastante afetado devido à inserção da fumigação, sofrendo elevação média de $131 \%$ no prejuízo nos pontos em que o dólar estava a $\mathrm{R} \$ 1,50$ e $\mathrm{R} \$ 2,41$, em relação ao cenário anterior. Como não foi efetuado controle fitossanitário eficiente na propriedade rural, neste caso o processo seguinte (B) elevou seus custos para controlar os insetos, afetando diretamente o lucro unitário dessa etapa. O processo de distribuição externa via modal rodoviário (D) foi o único que manteve lucros positivos em todas as simulações. Apesar do problema ter afetado com mais intensidade o processo (B), os demais tiveram reflexos negativos no seu lucro final.

Como nesta cadeia há a possibilidade de acordos sobre a responsabilidade do pagamento dos prejuízos, isto significa que os agentes envolvidos em processos que não estiveram diretamente relacionados aos problemas detectados em algumas etapas, também poderão arcar com os prejuízos da cadeia.

Ao analisar os lucros unitários finais da gérbera 2, como mostra a Figura 34(b), nota-se que se manteve o mesmo padrão de comportamento do Cenário 1, porém com maiores prejuízos para os processos (B), (C) e (D) nas simulações.

A utilização da fumigação em etapas posteriores poderá aumentar os riscos de perda do produto, se o processo de produção não for bem conduzido, por queima oriunda da aplicação de defensivos nas flores de corte, e reduzir a competitividade dessa cadeia em função da elevação de seus custos.

Se em cada processo não houver conhecimento sobre as características do produto exportado, poderão ocorrer distorções nas informações repassadas para os agentes dos processos subseqüentes ao longo da cadeia, com diminuição de sua coordenação, como se fosse um efeito chicote. Isto poderá ocasionar aumento nos custos e diminuição de sua responsividade, afetando o desempenho da cadeia como um todo, o que pode ser verificado pela estrutura de custos e lucros deste cenário ao compará-lo com os demais.

Como a cadeia não está totalmente integrada, se as perspectivas do aumento do volume produzido e exportado se concretizarem no curto prazo, poderá haver problemas de excesso ou falta de oferta de flores em determinadas datas do ano nos mercado 
nacional e internacional, devido à assimetria de informação com relação à demanda desses produtos.

A atitude do produtor cada vez mais será de extrema importância para a cadeia para que não ocorram quebras no contrato se os preços internacionais não forem compensadores. Pelo fato do setor de flores estar tentando se consolidar no mercado internacional, essa situação representa mais um entrave nessa cadeia. A legitimidade da ação de órgãos competentes faz-se necessária para orientar os agentes dessa cadeia para perceber melhor o ambiente internacional de competição mais acirrada, preparando-os para que conquistem espaço permanente nesse mercado e criando mecanismos eficientes de diferenciação do produto nos mercados interno e externo.

\subsubsection{Cenário 5: déficit logístico na cadeia, com falhas no processo de distribuição externa via modal aéreo}

Neste cenário foram consideradas perdas de 5\% processo de produção (A), $0 \%$ para o processo de distribuição interna via modal rodoviário (B), 7\% para o processo de distribuição externa via modal aéreo (C) e 3\% para o processo de distribuição externa via modal rodoviário (D). Apesar de haver melhorias em alguns processos, inclusive com refrigeração do veículo que transportou as flores do produtor para a central de distribuição, houve déficit logístico na eficiência do ciclo do pedido. Nesse caso, não foi utilizado contêiner ("câmara fria") no aeroporto, nem foram feitas fumigações nos aeroportos. Em 10\% dos embarques o caminhão refrigerado permaneceu no aeroporto por 6 horas devido a atrasos no vôo. Com a oscilação na temperatura no manuseio da carga entre os aeroportos, ocorreu perda de parte da carga no aeroporto em Miami, em função de exposição inadequada da carga a ambientes não refrigerados, agravando os problemas fitossanitários nas flores. O volume retido e queimado correspondeu a 5\% do total embarcado anualmente. Os custos, receitas e lucros totais para a cadeia de lírio são apresentados na Figura 35. 


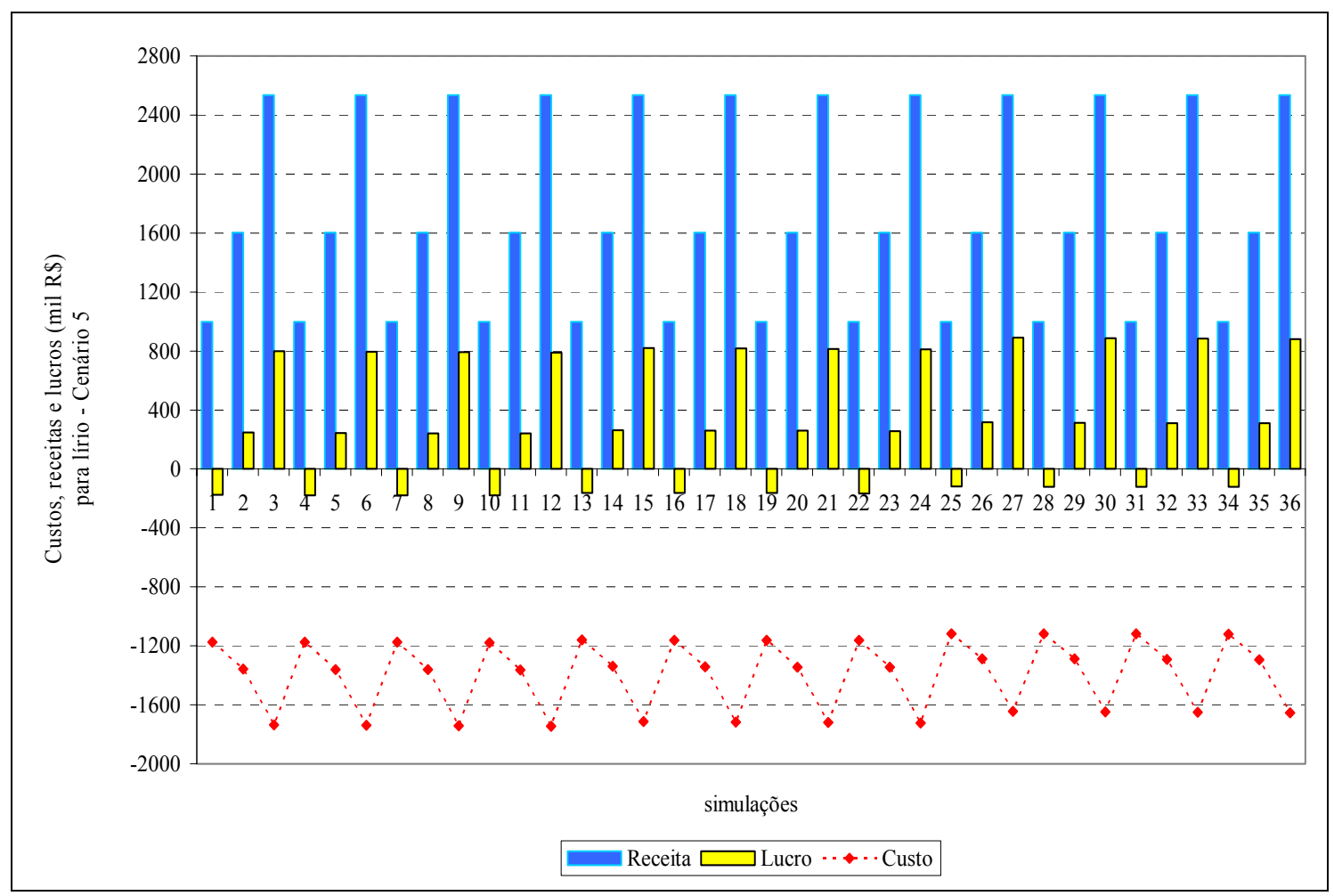

Figura 35 - Custos, receitas e lucros totais para a cadeia de lírio nas 36 simulações do Cenário 5

A cadeia do lírio neste cenário sofreu maior prejuízo em relação ao cenário anterior, uma vez que nos pontos com menor taxa de câmbio os lucros tiveram maior magnitude em termos absolutos quando comparados ao Cenário 4, apesar de terem mantido valores negativos em todas as simulações. O custo total foi, em média, 8\% maior do que no cenário anterior, e a receita total sofreu pequena redução de $2 \%$ na cadeia como um todo. Apesar desses gastos estarem relacionados a problemas distintos da cadeia, os dois cenários mostram que falhas pontuais podem estar reduzindo a eficiência de vários processos, com efeitos negativos sobre o lucro da cadeia como um todo.

Ao se relacionar esses custos dentro do Cenário 5, de maneira geral, houve incremento entre 40 e $49 \%$ nas simulações com maiores taxas de câmbio ao compará-las com a primeira, acentuado a partir da $27^{\mathrm{a}}$ simulação. Para essa flor o efeito da 
valorização câmbio repercutiu sobre o lucro total de maneira mais intensa do que nos cenários anteriores, verificando-se amplitudes menores ao longo das simulações.

Os lucros unitários brutos de cada um dos processos da flor lírio estão representados na Figura 36(a). Os novos parâmetros desse cenário afetaram de maneira diferente a cadeia de cada uma das flores, com relação ao verificado nos cenários anteriores, pois o processo de distribuição externa via modal aéreo (C) foi o mais afetado. Verificou-se aumento nos prejuízos desse processo, em média, de 106\%, em relação ao cenário anterior. As menores perdas ocorreram a partir da $27^{\mathrm{a}}$ simulação, com a utilização de 100 hastes por caixa. O processo de distribuição externa via modal rodoviário (D) também apresentou pior desempenho; apesar disso, manteve lucros positivos em todas as simulações. O processo de produção (A), por outro lado, apenas se recuperou nos pontos com as maiores taxas de câmbio e de maneira mais efetiva, com o maior volume de hastes por embalagem. 


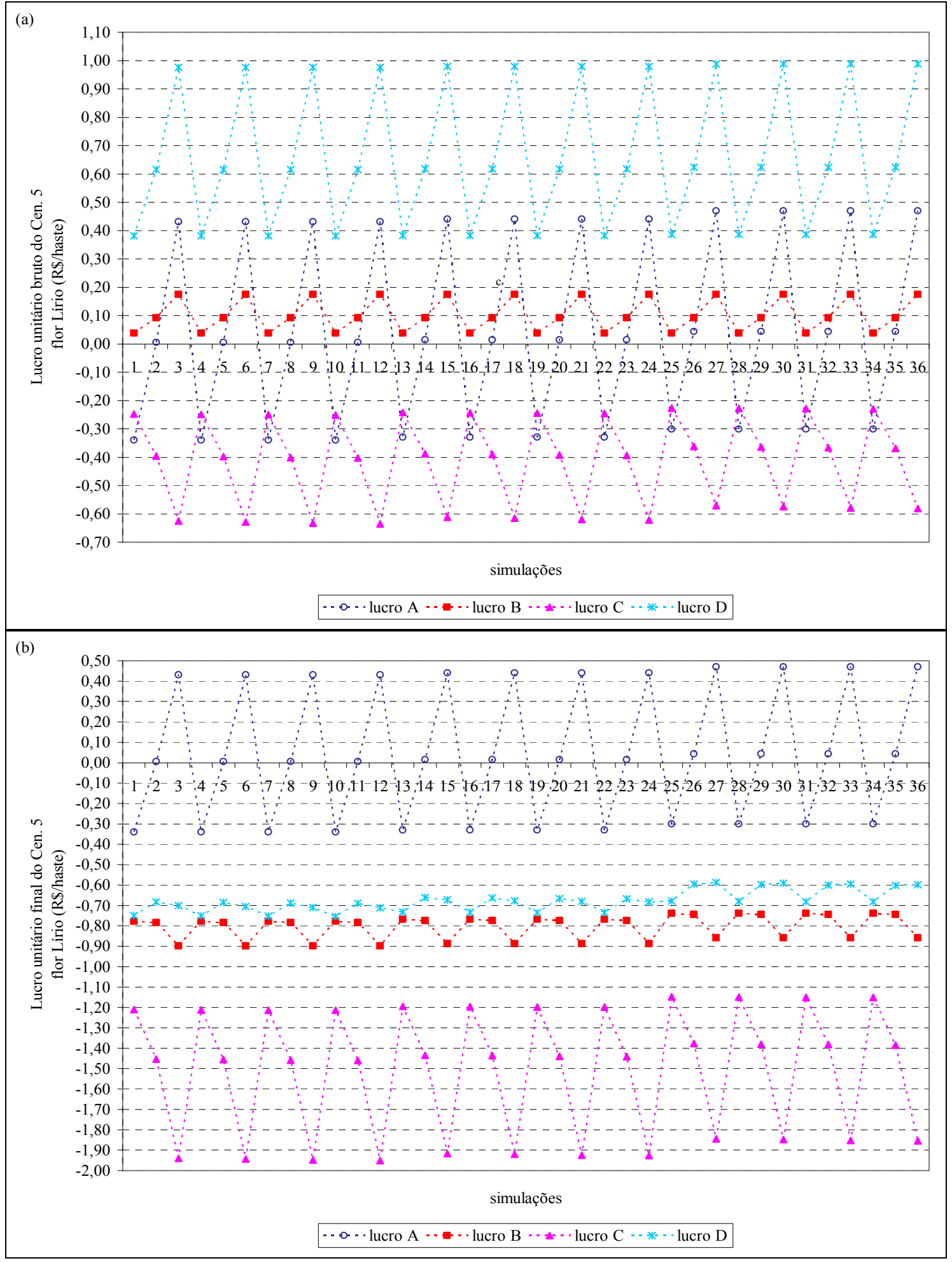

Figura 36 - Comparação dos lucros unitários de cada um dos processos para as produções bruta (a) e final (b) da flor lírio nas 36 simulações do Cenário 5 
Em relação aos lucros unitários dos produtos finais dessa flor, conforme mostra a Figura 36(b), observou-se que em termos do consumidor final apenas o processo de produção apresentou alguns valores positivos do lucro unitário. Os demais sofreram os reflexos da ineficiência da cadeia, com maior efeito sobre o processo de distribuição externa via modal aéreo $(\mathrm{C})$, cujos lucros tenderam à redução média de $14 \%$ nas simulações em relação ao cenário anterior.

No caso da gérbera 1 também houve elevação dos custos - em torno de 10\% - ao compará-los ao cenário anterior. Em termos gerais, houve grande amplitude nas magnitudes dos seus lucros totais, impactando de maneira distinta sobre cada um dos processos. Na Figura 37 estão apresentados os custos, receitas e lucros totais da cadeia de gérbera 1 para o Cenário 5.

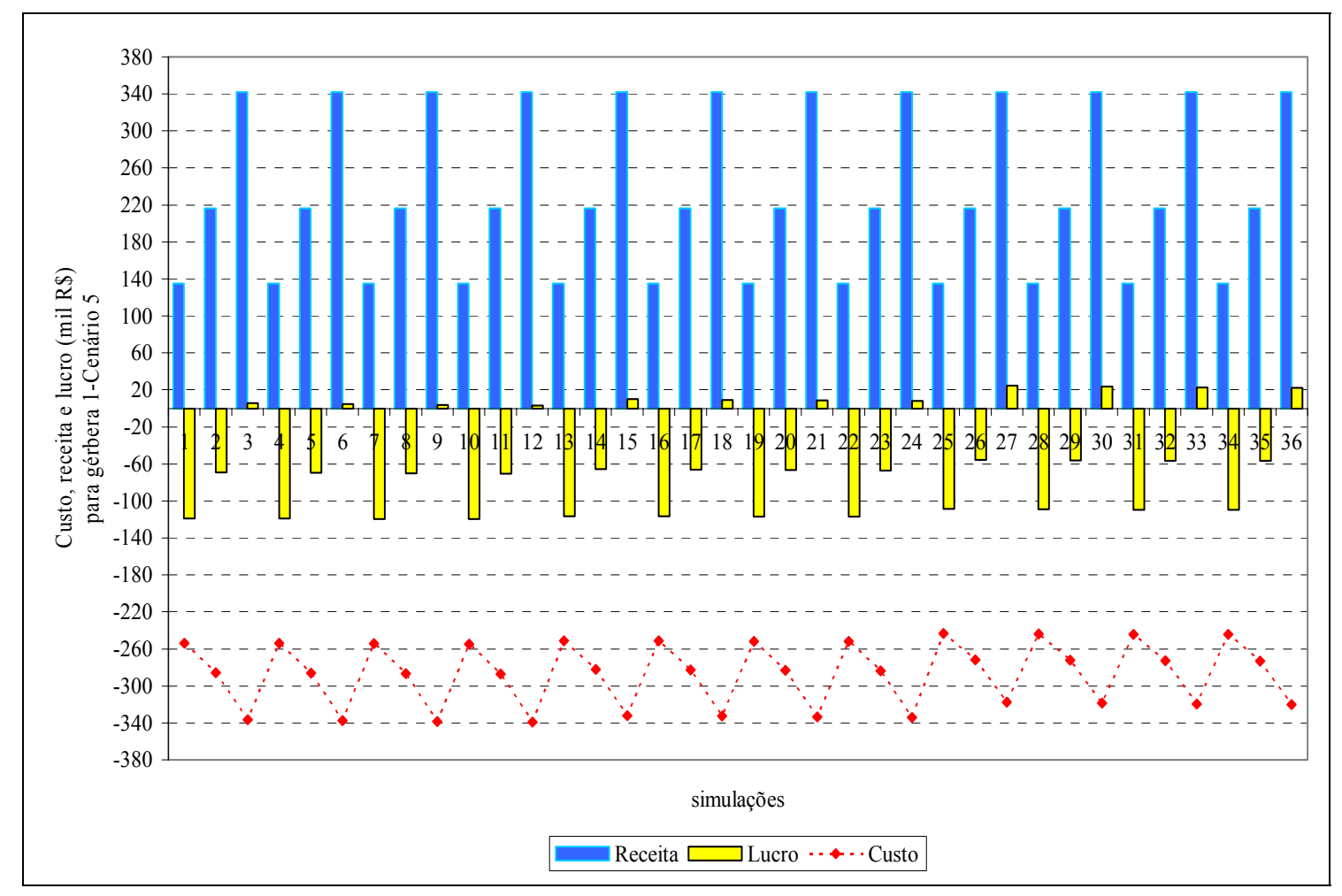

Figura 37 - Custos, receitas e lucros totais para a cadeia de gérbera 1 nas 36 simulações do Cenário 5 
Com relação aos lucros unitários brutos, apenas o processo de distribuição externa via modal rodoviário (D) da flor gérbera 1 apresentou valores positivos em todas as simulações, conforme verificado nos demais cenários. Houve redução média de $6 \%$ no seu lucro bruto, comparado ao cenário anterior. A Figura 38(a) mostra os lucros unitários brutos dessa cadeia. Neste cenário também foi registrada recuperação mais lenta do lucro do processo de produção (A), com prejuízos nas taxas de câmbio mais baixa e intermediária. O processo de distribuição interna via modal rodoviário (B) sofreu prejuízos em todas as simulações, menores do que os do processo de distribuição externa via modal aéreo (C), pois este concentrou os maiores problemas no embarque das mercadorias, sendo mais suscetível às variações do câmbio e do número de hastes por caixa. 


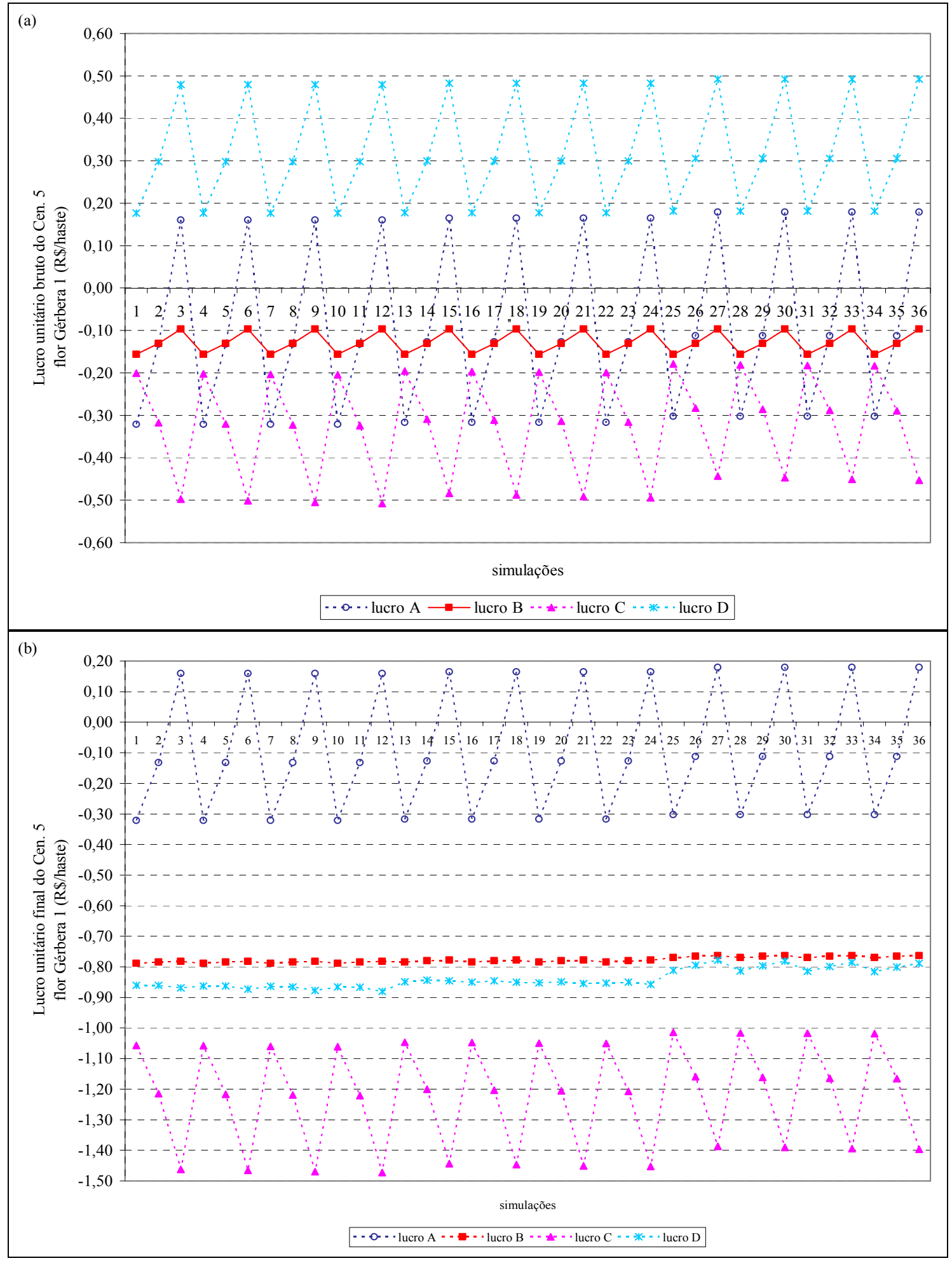

Figura 38 - Comparação dos lucros unitários de cada um dos processos para as produções bruta (a) e final (b) da flor gérbera 1 nas 36 simulações do Cenário 5 
Ao analisar os lucros unitários finais dessa cadeia, mostrados na Figura 38(b), nota-se que todos os processos, com exceção do (A), apresentaram prejuízos entre R\$ 0,70 e R $\$ 1,50$ por haste. O processo de distribuição interna via modal rodoviário (B) e o de distribuição externa via modal rodoviário (D) observaram tendências de comportamento semelhante ao longo das simulações, como o ocorrido no Cenário 3. Apesar do processo (C) ter sido mais afetado com a ineficiência da cadeia, o processo (A) foi o que apresentou as maiores amplitudes em seus lucros unitários, tal como foi constatado nos demais cenários.

Os resultados obtidos neste cenário para a cadeia de gérbera 2 foram distintos das demais flores. Os custos, receitas e lucros totais da flor gérbera 2 estão representados na Figura 39. Ao compará-la com o cenário anterior, essa cadeia sofreu aumento médio de $20 \%$ nos custos totais. Esse valor foi superior às outras flores ao analisá-las na mesma situação, mas todas tiveram custo mais alto na $3^{\mathrm{a}}$ simulação. A partir da relação entre lucro da cadeia com câmbio mais elevado e o mais baixo foram obtidos valores médios de $-3,00$ para 75 hastes caindo para $-6,80$ para 100 hastes. Houve também o efeito do frete aéreo em cada patamar de hastes por embalagem, com menor impacto sobre o lucro total quando comparado ao cenário anterior. No caso da gérbera 1 as relações permaneceram em torno de zero, pois a recuperação do lucro foi muito pequena a partir da $3^{\mathrm{a}}$ simulação em relação aos grandes prejuízos sofridos nos pontos com as menores taxas de câmbio. 


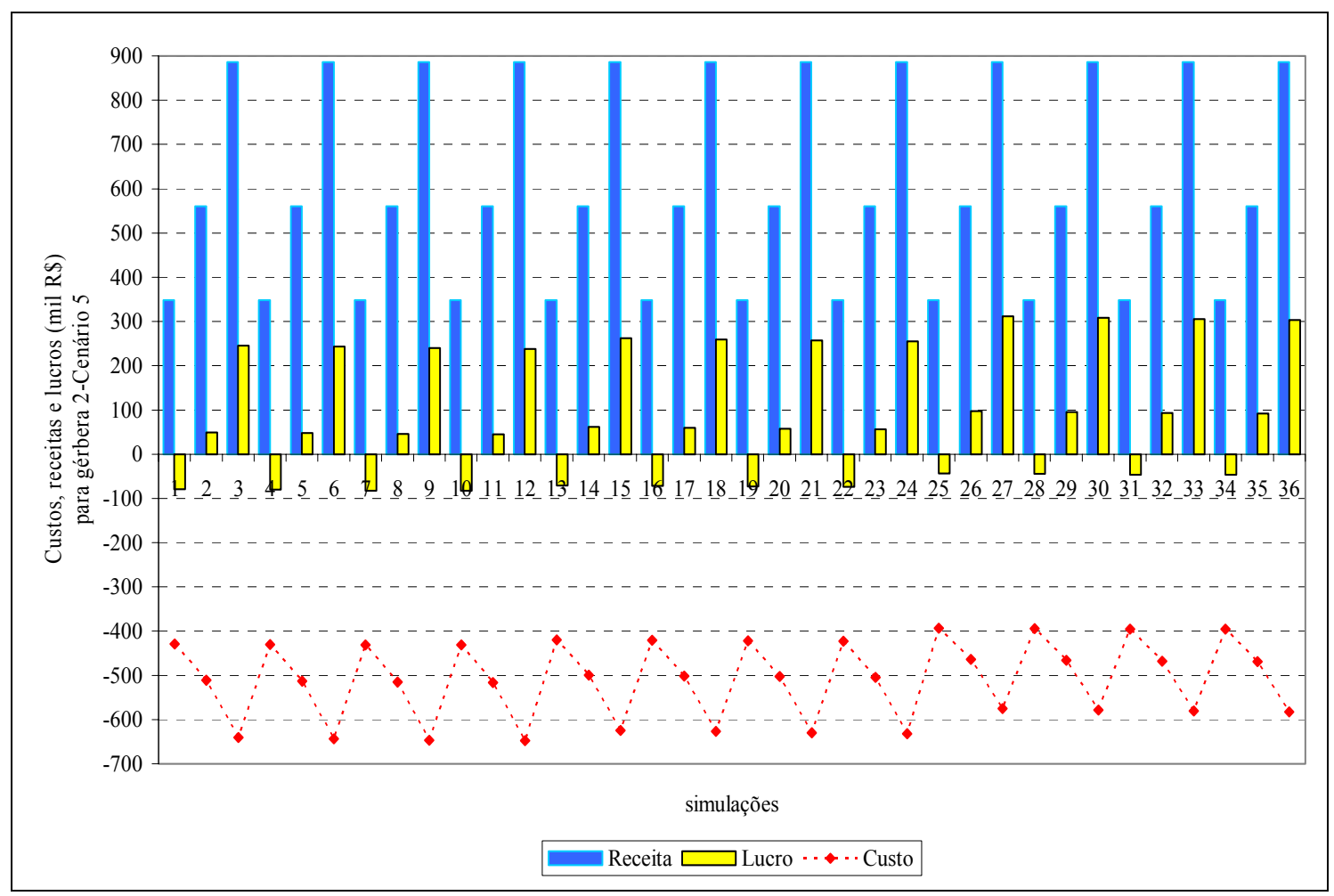

Figura 39 - Custos, receitas e lucros totais para a cadeia de gérbera 2 nas 36 simulações do Cenário 5

$\mathrm{Na}$ análise dos lucros unitários brutos da flor gérbera 2, apresentados na Figura 40(a), pode-se constatar que o desempenho dos processos de produção (A) e de distribuição externa via modal rodoviário (D) foi semelhante ao observado no cenário anterior. Em relações às outras flores, esta cadeia diferenciou-se em todos os cenários, pois esses dois processos seguiram a mesma tendência ao longo das simulações com diferenças bem pequenas entre seus lucros unitários nos pontos em que a taxa de câmbio atingiu $\mathrm{R} \$ 3,81$ por dólar, atingindo no máximo valores próximos de $\mathrm{R} \$ 0,40$ por haste. No caso do lírio, seus lucros brutos chegaram a $\mathrm{R} \$ 1,00$ e gérbera 1 a $\mathrm{R} \$ 0,50$ por haste. O processo de distribuição externa via modal aéreo (C) praticamente duplicou seus prejuízos em relação ao cenário anterior, apresentando recuperação maior nas simulações com 100 hastes por caixa. 


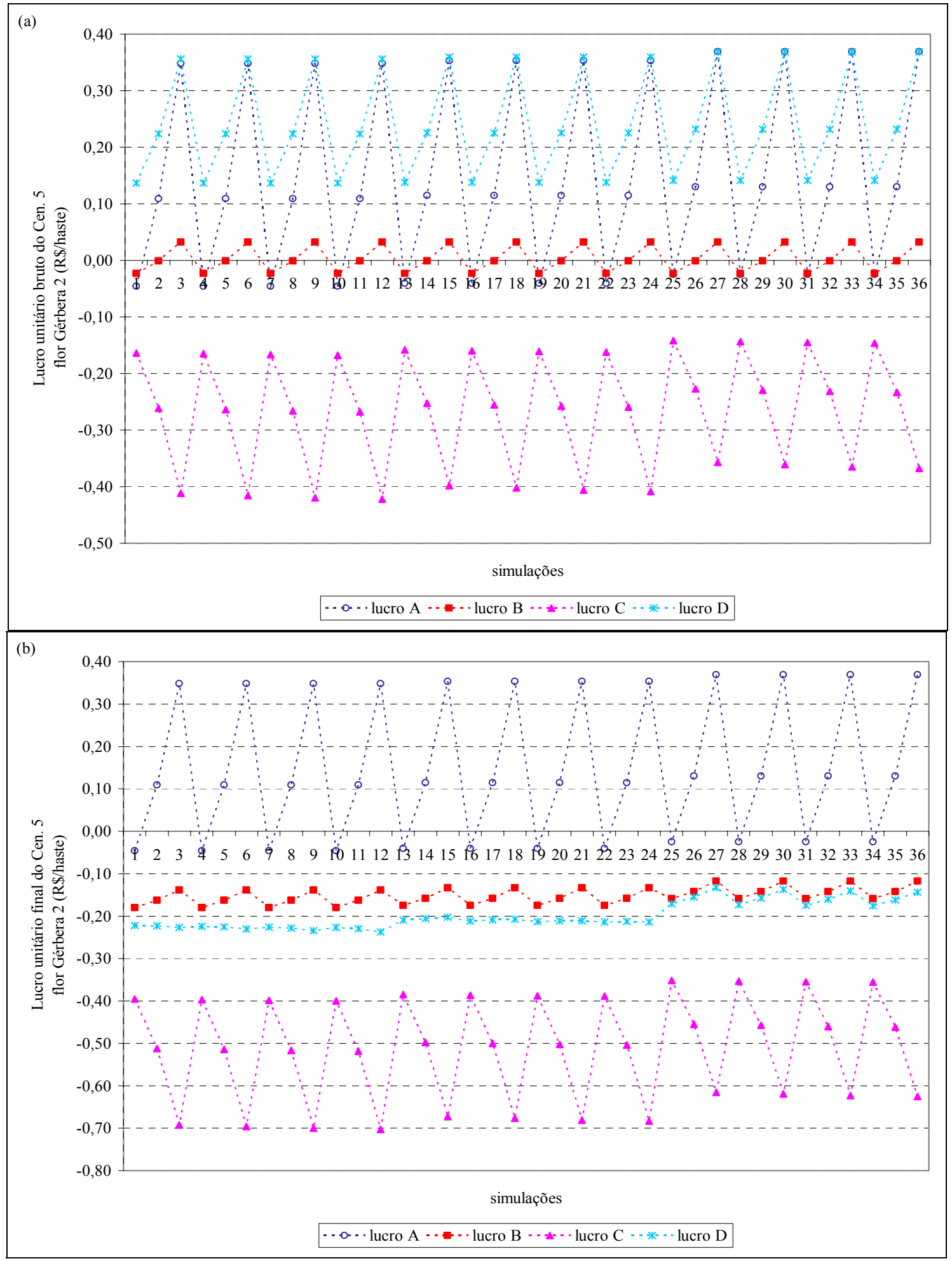

Figura 40 - Comparação dos lucros unitários de cada um dos processos para as produções bruta (a) e final (b) da flor gérbera 2 nas 36 simulações do Cenário 5 
Os lucros unitários do processo de produção (A) foram os únicos que permaneceram positivos ao considerar o consumidor final, mesmo que apenas nas taxas intermediária e mais elevada do câmbio. Nos demais processos, seus lucros unitários finais sofreram prejuízos, com variação entre $\mathrm{R} \$ 0,10$ e $\mathrm{R} \$ 0,25$ para os processos de distribuição interna via modal rodoviário (B) e de distribuição externa via modal rodoviário (D) e entre $\mathrm{R} \$ 0,35$ e $\mathrm{R} \$ 0,70$ para o processo de distribuição externa via modal aéreo (C) ao longo das simulações. Neste caso, este último foi o mais afetado, pois as falhas concentraram-se nessa etapa. A partir do aumento do número de hastes por caixa para 100, na $25^{\mathrm{a}}$ simulação, os lucros finais dos processos (B) e (D) tiveram comportamentos bem semelhantes. O frete aéreo foi variável importante, porém a sua variação foi menos importante do que os outros dois fatores analisados - taxa de câmbio e número de hastes por caixa.

As falhas descritas neste cenário, relacionadas aos aeroportos, constituem-se queixas freqüentes do setor como determinantes da melhor ou pior qualidade do produto, pois há vários procedimentos nos aeroportos quanto ao manuseio da carga que devem ser efetuados para seu embarque sem que existam condições ideais de acondicionamento para a sua categoria de produto perecível. Dentre eles, pode-se destacar: tempo utilizado para providenciar o despacho da carga, locais adequados de armazenamento da carga para mantê-la refrigerada, manuseio das caixas paletizadas ou não.

Em estudo realizado por Sá, Claro e Caixeta-Filho (2004), observou-se que houve melhoria no desempenho de empresa exportadora na Holanda, a partir do estabelecimento de relacionamentos anuais com companhias aéreas, pois houve possibilidade de diminuição de perdas decorrentes de eventuais falhas nos vôos.

De acordo com Gooley (2004), todas as operações efetuadas nos aeroportos e pelas companhias aéreas devem ter acompanhamento dos exportadores ou importadores para que minimizem os riscos de danos às cargas. Apesar das possibilidades de ocorrerem problemas no embarque das cargas ser maior em aeroportos menores e em países em desenvolvimento, o manuseio de produtos mais sensíveis, como é o caso das flores, necessita de esclarecimento maior e precisão maior quanto às oscilações de temperatura para que os agentes possam tomar decisões mais acertadas quanto ao seu 
transporte. As condições climáticas das aeronaves e seu espaço interno devem ser considerados no correto empacotamento e paletização das mercadorias. Se forem utilizados pallets feitos com materiais inadequados, ou mal dimensionados quanto ao peso máximo da carga ou com má distribuição da mercadoria na sua montagem, danos podem ser causados à essa carga e às demais que forem colocadas no mesmo compartimento dos aviões.

Seria importante que houvesse estreitamento maior no relacionamento entre exportadores e companhias aéreas para que pudessem ser feitos ajustes nos procedimentos realizados no embarque e desembarque das cargas nos aeroportos. À medida que houver exportações de flores brasileiras com maiores valores agregados, volumes mais significativos e com maior freqüência de utilização do modal aéreo, haverá maior sensibilização dos agentes quanto à realização de acordos entre as partes, beneficiando a cadeia como um todo.

\subsubsection{Análise geral dos cenários logísticos}

Para compreender melhor a estrutura de cada uma das cadeias de flores em diferentes cenários, foi realizada uma análise mais detalhada de seus custos, receitas e lucros.

Ao analisar o custo total, sem levar em conta os insumos logísticos, nota-se que nas simulações com a taxa de câmbio mais elevada apresentaram os maiores valores para todas as flores em todos os cenários, com exceção do 4, que além do câmbio mais alto também necessitou de maior número de hastes por caixa conforme exposto na Tabela 6. 
Tabela 6. Indicação das simulações com os maiores custos, receitas e lucros para cada um dos cenários $(\mathrm{R} \$)$

\begin{tabular}{|c|c|c|c|c|c|}
\hline \multirow[b]{2}{*}{ Itens } & \multicolumn{5}{|c|}{ Maiores valores para cada um dos cenários $(\mathrm{R} \$)$} \\
\hline & 1 & 2 & 3 & 4 & 5 \\
\hline \multicolumn{6}{|c|}{ Custo total sem insumo logístico $^{1}$} \\
\hline Lírio & $1.164 .175,00$ & $1.172 .310,00$ & $1.285 .841,00$ & $1.175 .222,00$ & $1.172 .310,00$ \\
\hline Gérbera1 & $195.371,00$ & $196.464,00$ & $211.780,00$ & $198.236,00$ & $196.464,00$ \\
\hline Gérbera2 & $256.831,00$ & $259.781,00$ & $299.584,00$ & $266.488,00$ & $259.781,00$ \\
\hline \multicolumn{6}{|c|}{ Custo total com insumo logístico ${ }^{2}$} \\
\hline Lírio & $1.563 .360,00$ & $1.588 .349,00$ & $1.694 .331,00$ & $1.573 .200,00$ & $1.744 .162,00$ \\
\hline Gérbera1 & $291.684,00$ & $295.512,00$ & $310.089,00$ & $294.370,00$ & $338.970,00$ \\
\hline Gérbera2 & $489.916,00$ & $502.212,00$ & $541.468,00$ & $499.071,00$ & $647.984,00$ \\
\hline \multicolumn{6}{|c|}{ Receita total sem produto logístico ${ }^{3}$} \\
\hline Lírio & $2.800 .751,00$ & $2.940 .788,00$ & $3.118 .680,00$ & $2.772 .743,00$ & $2.733 .207,00$ \\
\hline Gérberal & $378.256,00$ & $397.169,00$ & $421.194,00$ & $374.473,00$ & $369.134,00$ \\
\hline Gérbera2 & $977.458,00$ & $1.028 .903,00$ & $1.092 .658,00$ & $967.683,00$ & $956.276,00$ \\
\hline \multicolumn{6}{|c|}{ Receita total com produto logístico ${ }^{3}$} \\
\hline Lírio & $2.603 .255,00$ & $2.733 .418,00$ & $3.813 .596,00$ & $2.577 .043,00$ & $2.533 .751,00$ \\
\hline Gérbera1 & $351.627,00$ & $369.209,00$ & $514.893,00$ & 348.08 & $342.241,00$ \\
\hline Gérbera2 & $908.444,00$ & $956.257,00$ & $1.336 .405,00$ & $899.297,00$ & $886.404,00$ \\
\hline \multicolumn{6}{|c|}{ Lucro total com insumo logístico 4} \\
\hline Lírio & $1.290 .984,00$ & $1.408 .713,00$ & $1.482 .231,00$ & $1.255 .861,00$ & $1.088 .253,00$ \\
\hline Gérbera1 & $96.163,00$ & $111.727,00$ & $121.464,00$ & $90.401,00$ & $51.366,00$ \\
\hline Gérbera2 & $521.107,00$ & $562.023,00$ & $587.582,00$ & $504.559,00$ & $381.247,00$ \\
\hline \multicolumn{6}{|c|}{ Lucro total com produto logístico ${ }^{5}$} \\
\hline Lírio & $1.439 .366,00$ & $1.561 .408,00$ & $2.528 .064,00$ & $1.404 .367,00$ & $1.361 .742,00$ \\
\hline Gérbera1 & $156.330,00$ & $172.823,00$ & $303.193,00$ & $150.512,00$ & $145.855,00$ \\
\hline Gérbera2 & $651.863,00$ & $696.739,00$ & $1.037 .092,00$ & $635.036,00$ & $626.886,00$ \\
\hline \multicolumn{6}{|c|}{ Lucro total sem insumo e produto logísticos ${ }^{5}$} \\
\hline Lírio & $1.636 .861,00$ & $1.768 .778,00$ & $1.833 .148,00$ & $1.600 .068,00$ & $1.561 .197,00$ \\
\hline Gérbera1 & $182.959,00$ & $200.783,00$ & $209.494,00$ & $176.898,00$ & $172.748,00$ \\
\hline Gérbera2 & $720.877,00$ & $769.385,00$ & $793.345,00$ & $703.422,00$ & $696.758,00$ \\
\hline \multicolumn{6}{|c|}{ Lucro total com insumo e produto logísticos ${ }^{4}$} \\
\hline Lírio & $1.093 .489,00$ & $1.201 .343,00$ & $2.177 .147,00$ & $1.060 .161,00$ & $888.797,00$ \\
\hline Gérbera1 & $69.535,00$ & $83.767,00$ & $215.163,00$ & $64.015,00$ & $24.473,00$ \\
\hline Gérbera2 & $452.093,00$ & $489.377,00$ & $831.330,00$ & $436.173,00$ & $311.377,00$ \\
\hline
\end{tabular}


Ao inserir os insumos logísticos, a simulação 12 apresentou os maiores custos para todas as flores em todos os cenários, pois nesse ponto convergiram os maiores valores de taxa de câmbio e de frete aéreo e o menor número de hastes por caixa. Como no Cenário 5 ocorreram problemas sérios nos aeroportos, isso influiu significativamente no incremento dos custos para todas as flores, prejudicando sobremaneira o seu lucro e, conseqüentemente, a competitividade dessas cadeias.

Dadas as características do Cenário 3 em agregar as melhores condições logísticas, apesar de haver inclusão de custos nesse processo, houve compensação parcial em função da redução nas perdas por ineficiência da cadeia. Isso repercutiu em ganhos nas receitas totais, cujos maiores valores foram atingidos nos pontos em que o dólar foi cotado a R\$ 3,81. Com relação aos maiores lucros, observa-se que há influência grande dos insumos e produtos logísticos.

A Tabela 7 apresenta os valores mínimos para custos, receitas e lucros para a cadeia como um todo. Nos custos, sem considerar os insumos logísticos, há destaque para as simulações com os menores valores de taxa de câmbio e do número de hastes por caixa, com exceção do Cenário 4. Nesse caso foram incluídas simulações com menores valores de taxa de câmbio e maior número de hastes por embalagem, refletindo em maiores perdas devido a falhas na fumigação do produto. Apesar disso, a menor receita total ocorreu no Cenário 5, relacionada à menor valorização do real em relação ao dólar, influenciando diretamente os lucros totais. 
Tabela 7. Indicação das simulações com os menores custos, receitas e lucros para cada um dos cenários $(\mathrm{R} \$)$

\begin{tabular}{|c|c|c|c|c|c|}
\hline \multirow[b]{2}{*}{ Itens } & \multicolumn{5}{|c|}{ Menores valores para cada um dos cenários $(\mathrm{R} \$)$} \\
\hline & 1 & 2 & 3 & 4 & 5 \\
\hline \multicolumn{6}{|c|}{ Custo total sem insumo logístico $^{1}$} \\
\hline Lírio & $833.425,00$ & $836.588,00$ & $88.1261,00$ & $842.211,00$ & $836.588,00$ \\
\hline Gérbera1 & $169.475,00$ & $169.895,00$ & $175.919,00$ & $171.753,00$ & $169.895,00$ \\
\hline Gérbera2 & $211.069,00$ & $212.193,00$ & $227.841,00$ & $218.749,00$ & $212.193,00$ \\
\hline \multicolumn{6}{|c|}{ Custo total com insumo logístico ${ }^{2}$} \\
\hline Lírio & $1.059 .542,00$ & $1.071 .334,00$ & $1.114 .234,00$ & $1.067 .498,00$ & $1.116 .533,00$ \\
\hline Gérbera1 & $228.241,00$ & $229.948,00$ & $235.808,00$ & $230.356,00$ & $243.433,00$ \\
\hline Gérbera2 & $343.838,00$ & $349.481,00$ & $365.418,00$ & $351.010,00$ & $392.816,00$ \\
\hline \multicolumn{6}{|c|}{ Receita total sem produto logístico ${ }^{3}$} \\
\hline Lírio & $1.102 .658,00$ & $1.157 .791,00$ & $1.227 .827,00$ & $1.091 .631,00$ & $1.076 .066,00$ \\
\hline Gérbera1 & $148.920,00$ & $156.366,00$ & $165.824,00$ & $147.430,00$ & $145.328,00$ \\
\hline Gérbera2 & $384.826,00$ & $405.080,00$ & $430.180,00$ & $380.978,00$ & $376.487,00$ \\
\hline \multicolumn{6}{|c|}{ Receita total com produto logístico ${ }^{3}$} \\
\hline Lírio & $1.024 .904,00$ & $1.076 .149,00$ & $1.501 .416,00$ & $1.014 .584,00$ & $997.540,00$ \\
\hline Gérbera1 & $138.436,00$ & $145.358,00$ & 202.714 & $37.042,00$ & $134.741,00$ \\
\hline Gérbera2 & $357.655,00$ & $376.479,00$ & $526.144,00$ & $354.054,00$ & $348.978,00$ \\
\hline \multicolumn{6}{|c|}{ Lucro total com insumo logístico ${ }^{4}$} \\
\hline Lírio & $1.957,00$ & $43.240,00$ & $69.142,00$ & $-19.815,00$ & $-100.587,00$ \\
\hline Gérbera1 & $-85.689,00$ & $-80.268,00$ & $-76.861,00$ & $-90.017,00$ & $-109.173,00$ \\
\hline Gérbera2 & $18.293,00$ & $31.710,00$ & $40.156,00$ & $4.834,00$ & $-55.032,00$ \\
\hline \multicolumn{6}{|c|}{ Lucro total com produto logístico ${ }^{5}$} \\
\hline Lírio & $191.192,00$ & $239.261,00$ & $619.847,00$ & $169.825,00$ & $160.652,00$ \\
\hline Gérbera1 & $-31.116,00$ & $-24.615,00$ & $26.715,00$ & $-35.372,00$ & $-35.232,00$ \\
\hline Gérbera2 & $146.336,00$ & $164.023,00$ & $298.031,00$ & $133.078,00$ & $136.522,00$ \\
\hline \multicolumn{6}{|c|}{ Lucro total sem insumo e produto logísticos ${ }^{5}$} \\
\hline Lírio & $268.946,00$ & $320.902,00$ & $346.257,00$ & $246.873,00$ & $239.178,00$ \\
\hline Gérberal & $-20.630,00$ & $-13.608,00$ & $-10.174,00$ & $-24.983,00$ & $-24.645,00$ \\
\hline Gérbera2 & $173.507,00$ & $192.624,00$ & $202.068,00$ & $160.002,00$ & $164.030,00$ \\
\hline \multicolumn{6}{|c|}{ Lucro total com insumo e produto logísticos ${ }^{4}$} \\
\hline Lírio & $-75.798,00$ & $-38.402,00$ & $342.731,00$ & $-96.863,00$ & $-179.113,00$ \\
\hline Gérbera1 & $-96.173,00$ & $-91.276,00$ & $-39.972,00$ & $-100.405,00$ & $-119.761,00$ \\
\hline Gérbera2 & $-8.878,00$ & $3.109,00$ & $136.120,00$ & $-22.090,00$ & $-82.541,00$ \\
\hline
\end{tabular}


Com relação às cadeias estudadas, a do lírio destacou-se como a mais rentável, apesar de incorrer nos maiores custos, enquanto a de gérbera 1 apresentou os menores lucros e custos. Dada a sua condição de produção em menor escala, foi a única que sofreu prejuízos em todos os cenários nas simulações que apresentaram as características menos competitivas. A cadeia de gérbera 2 também obteve bom desempenho ao longo dos cenários formulados, observando maior flexibilidade com relação às variações do dólar em comparação à gérbera 1 .

Os custos logísticos representam um componente importante dentro da cadeia. A Figura 41 apresenta a porcentagem desses custos em relação ao custo total nos 5 cenários analisados para as cadeias de lírio, gérbera 1 e gérbera 2 . Houve menor concentração dos custos logísticos no Cenário 3, em função de ter minimizado as falhas na cadeia, apesar de apresentar problemas menores em alguns processos, com ganho em eficiência relacionado ao superávit logístico em algumas etapas. Os maiores custos logísticos permaneceram no Cenário 5 para todas as flores estudadas, devido à ocorrência de vários fatores de insucesso no processo de distribuição externa via modal aéreo (C). 


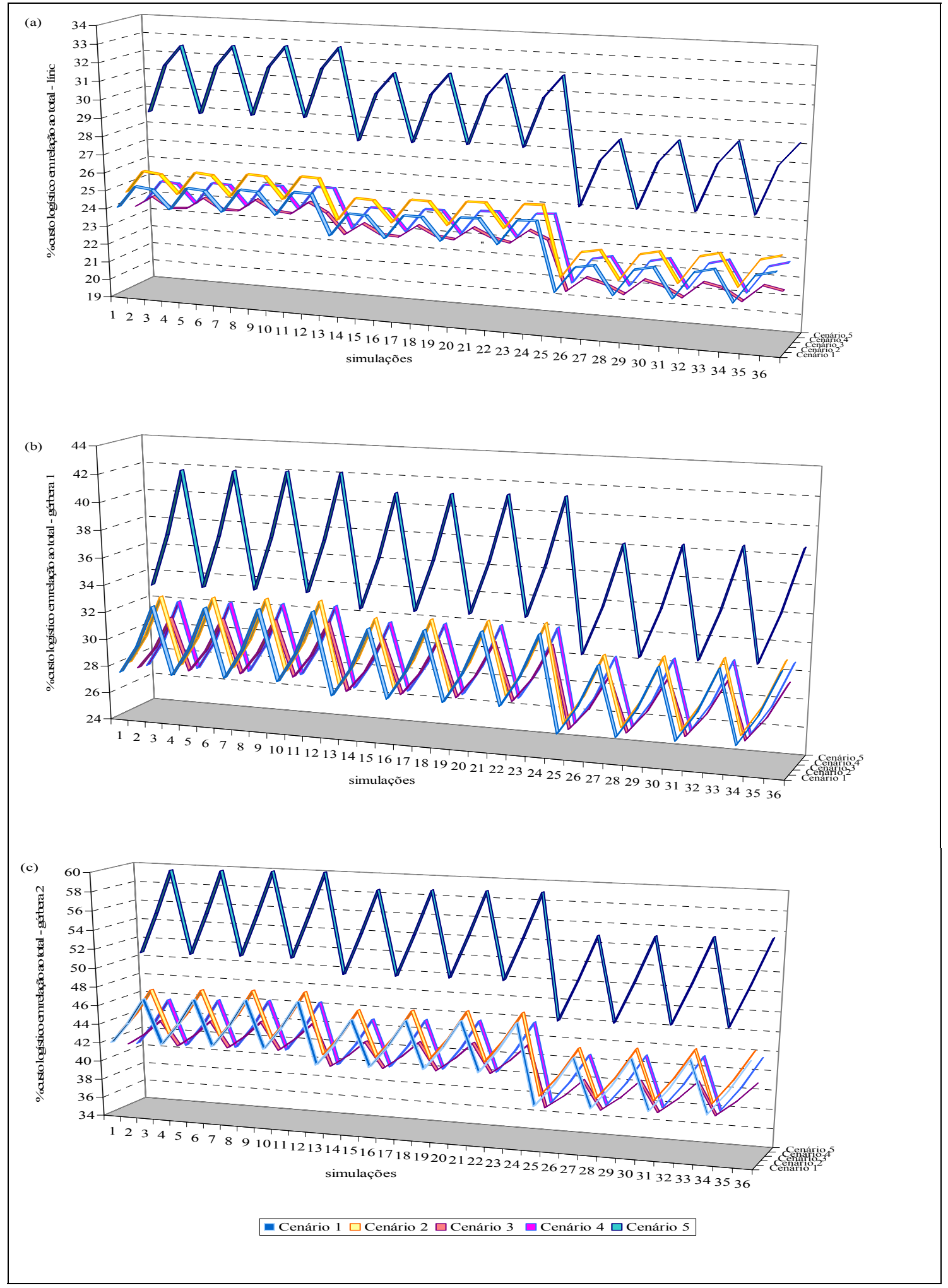

Figura 41 - Porcentagem do custo logístico em relação ao custo total para as 36 simulações dos 5 cenários da flor lírio (a), gérbera 1 (b) e gérbera 2 (c) 
Em geral, os cenários tiveram tendência de redução dos custos logísticos ao longo das simulações, com o aumento do número de hastes por embalagem, dado que a maior parte desses custos é medida em caixas. Constatou-se que a cadeia da flor gérbera 2 apresentou percentual de custos logísticos bem maior do que as outras flores. Como as três cadeias utilizaram os mesmos canais de comercialização, isso provavelmente está relacionado à sua estrutura produtiva, com peso maior em gastos com câmara fria e embalagens em relação às demais despesas, diferenciando-a das demais. No caso da cadeia de gérbera 1 , o processo de produção fez uso mais intensivo de fertilizantes e não utilizou instalações climatizadas. O lírio sofreu maior influência de despesas com importação de bulbos e com embalagens.

De acordo com World Bank (2002), os custos de transporte afetam de maneira significativa o crescimento das exportações de bens primários em função da redução de sua rentabilidade no longo prazo. Há também impacto sobre as importações de bens de capital, cujos preços tornam-se mais altos, e sobre os mercados de destino. De maneira geral, com os custos mais elevados, os preços tendem a ser menos competitivos do que os países concorrentes. Isso pode acarretar em restrição do mercado consumidor e redução do potencial de crescimento do país exportador.

No Brasil, o aperfeiçoamento logístico tem contribuído para que esses custos sejam reduzidos, como por exemplo, o desenvolvimento e implantação do Sistema Integrado de Comércio Exterior (SISCOMEX). Esse sistema permitiu diminuição na burocracia e no tempo para encaminhamento da documentação para exportação brasileira, contudo há a necessidade de ajustes nas operações dos aeroportos para agilizar o despacho aduaneiro, reduzir os custos de transação envolvidos e garantir o correto acondicionamento dos produtos perecíveis exportados. Quanto mais distantes forem os mercados de destino, maiores dificuldades serão enfrentadas para viabilizar a coordenação entre os agentes e os modais de transporte para que o produto seja entregue com qualidade e no prazo determinado.

Outro ponto que afeta os custos da exportação de flores diz respeito ao frete aéreo. Segundo World Bank (2004), os países em desenvolvimento mais suscetíveis a taxas mais altas são aqueles que exportam volumes pequenos dos produtos e estão 
localizados em regiões mais distantes dos grandes centros econômicos. Além disso, a existência de poucas companhias aéreas para realizar determinadas rotas influencia no preço do frete, pois há economias de escala e de escopo envolvidas. Neste estudo, observou-se que $10 \%$ de aumento no volume de tráfego aéreo acarretaram em queda de mais de $1 \%$ no valor do frete.

De acordo com Thoen et al. (2001), os altos preços do frete aéreo foram determinantes para que houvesse acréscimo bem maior do número de hastes por caixa das flores exportadas pelo Quênia, prejudicando o empilhamento das caixas e a eficiência do pré-cooling. Se esse sistema não for bem conduzido, há perda da qualidade do produto até que chegue aos consumidores europeus. Nesse país houve conscientização dos grandes exportadores para que a cadeia do frio fosse mantida com o intuito de minimizar a perda de qualidade das flores entre a colheita e o seu consumo. Apenas grandes exportadores têm investido em instalações para permitir controle contínuo da temperatura do produto e garantir toda a supervisão e correto acondicionamento das flores antes do seu embarque, a partir da criação de joint ventures com empresas agenciadoras de carga. Os demais comercializam produtos com menor padrão de qualidade, por não disporem desse investimento adicional.

Conforme Salin \& Nayga Junior (2003), a utilização eficiente de equipamentos e processos para manter os produtos refrigerados, ou seja, cadeia do frio, pode influenciar na diferenciação e na vantagem competitiva de mercadorias de valor agregado mais elevado.

Como complemento à análise desses indicadores, foi utilizada a proporção entre lucro e custo, considerando insumos e produtos logísticos, para analisar o desempenho de cada um dos cenários nas 36 simulações para as três cadeias analisadas, conforme mostra a Figura 42. Optou-se por utilizar os valores positivos para custos e receitas. Observa-se que para a flor lírio o pior cenário foi o 5, cuja relação oscilou entre 54,00 e $-15,20$, ou seja, há lucros de $\mathrm{R} \$ 54,00$ e prejuízos de $\mathrm{R} \$ 15,20$ no máximo para cada $\mathrm{R} \$$ 1,00 gasto na cadeia com exportação de flores. Os picos foram atingidos nas simulações 27, 30, 33 e 36, que correspondem às maiores taxas de câmbio e ao maior número de hastes por embalagem. 


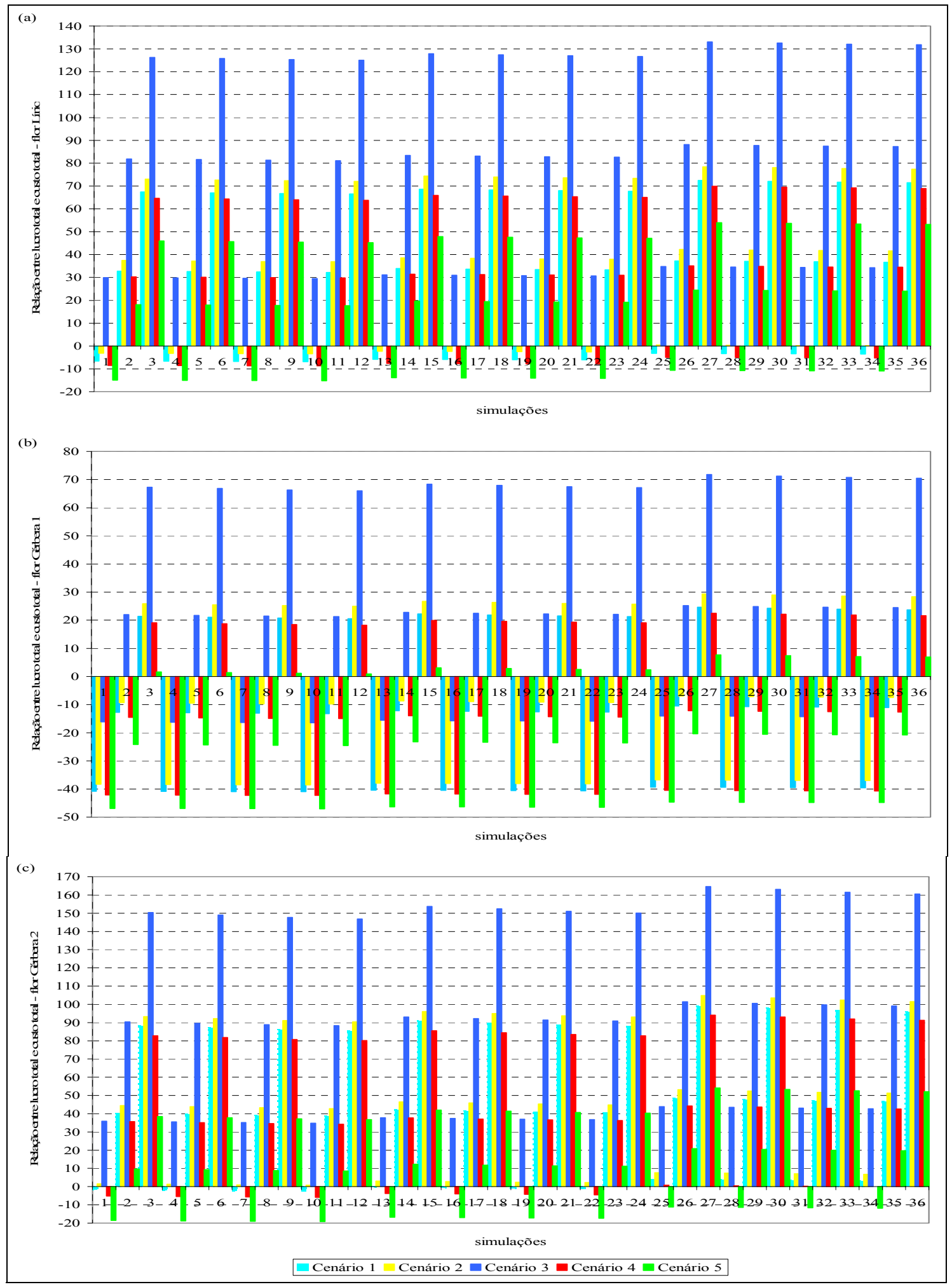

Figura 42 - Relação entre lucro e custo, considerando insumos e produtos logísticos de (a) lírio, (b) gérbera 1 e (c) gérbera 2 
O melhor cenário para a cadeia do lírio foi o 3 , sendo que ao longo das simulações os maiores valores foram observados nos pontos em que as taxas de câmbio assumiram valores intermediário e mais elevado. Seu pico foi atingido na simulação 27, com o patamar de 133 , ou seja, para $R \$ 1,00$ gasto foi registrado lucro de $R \$ 133,00$ para a cadeia como um todo nesse cenário. Esse valor corresponde a praticamente 145\% de acréscimo no lucro total em relação à mesma simulação no Cenário 4. Os insumos logísticos que mais afetaram a cadeia nesses cenários foram gastos com embalagem, taxas de comercialização, fretes rodoviário e aéreo, despacho aduaneiro e câmara fria.

Para a flor gérbera 1 observam-se resultados semelhantes com impactos menores nessa cadeia. Neste caso, o Cenário 3 apresentou as melhores relações nas simulações em que o real estava mais valorizado em relação ao dólar, atingindo o valor máximo de 71,80 na $27^{\mathrm{a}}$ simulação e o mínimo de 14,00 na $25^{\mathrm{a}}$ simulação. Por outro lado, o Cenário 5 também foi o pior, com a relação oscilando entre 47,10 e 7,70. Na cadeia de gérbera 2 ficou mais evidente a disparidade entre as relações dos Cenários 3 e 5, quando comparado às demais flores, pois nos piores resultados apenas o Cenário 5 apresentou valores negativos em todas as simulações para a menor taxa de câmbio ( $\mathrm{R} \$ 1,50$ por dólar). O Cenário 3 atingiu maior valor de 164,60 na $27^{\mathrm{a}}$ simulação, bem superior aos demais cenários sob as mesmas condições.

A partir de alterações nos parâmetros de cada um dos cenários, poderá haver mudança nas relações entre seus lucros e custos, refletindo diretamente no desempenho de cada um dos processos da cadeia.

Uma prática bastante utilizada pelo setor de flores é o consórcio logístico nas exportações, ou seja, o rateio das despesas dos produtores, com o pagamento proporcional ao volume comercializado por embarque. Isso se justifica pela pequena quantidade exportada. Nos cenários foi adotado número médio de quatro produtores por embarque, de acordo com informações do setor. Com o intuito de se conhecer o impacto dessa variável nos cenários com o melhor e o pior resultados, foram calculados os acréscimos nos custos totais comparando o rateio de despesas entre 1 e 4, 10 e 20 produtores, e entre 4 e 10 produtores para cada uma das cadeias de flores estudadas, conforme mostra a Tabela 8. Em geral, a partir da divisão dos gastos entre quatro 
produtores, as reduções nos custos foram bem menores ao compará-los com apenas um. Para o caso da gérbera 1, em que havia menor volume comercializado, houve benefício maior com o rateio das despesas em relação às demais cadeias, afetando diretamente seu lucro total.

Tabela 8. Taxa média de crescimento do custo total (\%) considerando o rateio das despesas de exportação entre 1, 4, 10 e 20 produtores

\begin{tabular}{|c|c|c|c|c|}
\hline \multirow[t]{2}{*}{$\begin{array}{l}\text { Cenários/cadeias } \\
\text { de flores }\end{array}$} & \multicolumn{4}{|c|}{$\begin{array}{l}\text { Taxa média de crescimento do custo total com rateio das despesas } \\
\qquad(\%)\end{array}$} \\
\hline & $1 \mathrm{e} 4$ prod. & $1 \mathrm{e} 10$ prod. & 1 e 20 prod. & 4 e 10 prod. \\
\hline \multicolumn{5}{|l|}{ Cenário 3} \\
\hline Lírio & 3,30 & 4,00 & 4,20 & 0,70 \\
\hline Gérbera 1 & 16,60 & 20,60 & 22,00 & 3,40 \\
\hline Gérbera 2 & 10,00 & 12,30 & 13,00 & 2,10 \\
\hline \multicolumn{5}{|l|}{ Cenário 5} \\
\hline Lírio & 3,50 & 4,20 & 4,50 & 0,70 \\
\hline Gérbera 1 & 16,90 & 21,00 & 22,50 & 3,50 \\
\hline Gérbera 2 & 9,60 & 11,80 & 12,50 & 2,00 \\
\hline
\end{tabular}

Diante desses resultados, ressalta-se a importância de se ter controle mais efetivo de cada uma das etapas do processo de exportação de flores de corte, para que se possa minimizar as falhas de toda a cadeia. A construção desses cenários logísticos pode facilitar a visualização dos impactos decorrentes de mudanças nas relações entre os processos ou agentes, ou mesmo no ambiente político e econômico do país, permitindo que se analise a flexibilidade de cada um dos insumos dessa cadeia, facilitando o gerenciamento e avaliação de seu desempenho no curto e longo prazos.

Ao relacionar os resultados obtidos nos cenários com os processos de exportação de flores de corte, pode-se inferir que a produção constitui-se em elo vital para a cadeia. Isto se justifica não apenas porque nesta fase há geração do produto a ser exportado, mas também por haver possibilidade de gerenciamento da qualidade das flores por período de tempo maior do que nas outras etapas, por meio da condução de técnicas e procedimentos mais adequados ao seu manejo durante todo o período de seu cultivo.

Nos cenários 1, 2 e 4 foram observadas falhas operacionais no processo produtivo, que repercutiram nos demais processos de diferentes maneiras. No Cenário 1 
foram apontados problemas no processo de produção relacionados a dificuldades no manejo na condução da cultura, que refletiram em maiores perdas das flores nessa etapa. A partir de aprimoramento das técnicas e emprego de tecnologias mais adequadas, o Cenário 2 ilustrou que os problemas puderam ser reduzidos, apesar de ainda existirem falhas nos procedimentos dos agentes envolvidos nos outros processos.

No Cenário 4, a falta de esclarecimento por parte dos players envolvidos nos processos de produção (A) e de distribuição interna via modal rodoviário (B) sobre a necessidade do cumprimento das regras impostas pelo mercado internacional com relação aos cuidados pós-colheita, influenciou de maneira significativa a qualidade do produto e os entraves ao longo de toda a cadeia. Os impactos negativos observados nesse cenário foram agravados nas etapas subseqüentes por não serem mantidas condições mínimas para que as flores fossem armazenadas e transportadas de maneira adequada.

Apesar de haver esforço entre os agentes envolvidos nos processos A e B para contornar os problemas que possam ocorrer em cada embarque, verificou-se no Cenário 5 que as falhas nos procedimentos nos aeroportos podem acarretar em danos sérios tanto à qualidade das flores quanto às negociações com os países importadores do produto. Esses problemas podem estar relacionados a falhas técnicas por não conhecimento de manuseio e transporte de perecíveis por parte dos agentes envolvidos nesse processo, mas, também, à falta de interesse em priorizar esses embarques, cujo valor agregado ainda não é expressivo quando comparado a outras mercadorias exportadas.

Seria importante que se atingisse nível melhor de relacionamento entre os agentes da cadeia, a partir de ajustes em seus lead times e na eficácia de cada um dos processos, para que o processo de exportação de flores de corte se torne mais freqüente e ganhe expressão no mercado internacional. No Cenário 3 constatou-se que a melhoria no desempenho de cada um dos processos está diretamente ligada à relação de cooperação entre os seus players, a partir da eliminação ou redução de falhas em cada uma das fases da exportação de flores de corte. 


\section{CONCLUSÕES}

O desenvolvimento do agronegócio de flores depende do inter-relacionamento de vários setores da sociedade. Com a globalização, deve-se também atentar para as novas tecnologias adotadas para impulsionar os setores, uma vez que suas adequadas implantações, em quaisquer partes da cadeia produtiva, determinam o seu efetivo crescimento ou degradação. Por outro lado, a estrutura organizacional de cada um dos agentes e suas estratégias competitivas, principalmente relacionadas à logística, devem ser levadas em conta, para que se possa dimensionar os problemas da cadeia e as possíveis alternativas de solucioná-los.

Apesar de ser estático, o modelo insumo-produto de processo constituiu-se numa ferramenta de apoio consistente para avaliar os impactos de alterações nos diversos processos previstos na cadeia de exportação de flores, uma vez que se pôde estruturar as informações de maneira mais agregada e também obter detalhamento maior de cada uma das etapas da cadeia. Desde que se possa resolver ou minimizar os conflitos entre os seus agentes, poderão ser montadas estratégias para a gestão da cadeia de suprimentos, permitindo que as empresas atinjam o mercado externo, consigam satisfazer o cliente, obter ganhos de competitividade e rentabilidade no longo prazo.

A partir da análise dos cenários logísticos foi possível perceber que a integração entre os players é muito importante para que cada processo seja otimizado, maximizando o lucro da cadeia como um todo. À medida que ocorrem falhas em alguma etapa, vários parâmetros poderão ser afetados, comprometendo a eficiência da exportação de cada um dos produtos. Para cada tipo de cadeia há relações específicas entre os agentes, influenciando de maneira diferente na eficiência de cada processo. 
Em todos os cenários a taxa de câmbio destacou-se como o principal fator que influenciou as receitas e custos de todas as flores estudadas. Seu impacto, no entanto, foi proporcional ao volume exportado e ao número de hastes por caixa. Para maior quantidade de hastes comercializadas houve maior flexibilidade em cada um dos processos e em toda a cadeia para reduzir os prejuízos. $\mathrm{O}$ aumento do número de hastes em cada embalagem teve efeito de reduzir os custos totais ao longo das simulações. Apesar do frete aéreo se constituir numa das variáveis logísticas importantes no processo de distribuição externa via modal aéreo $(\mathrm{C})$, sua variação influenciou de maneira menos intensa os custos em cada uma das situações.

Pôde-se constatar na análise dos cenários que os cuidados pós-colheita também são o ponto chave para o melhor desempenho da cadeia. Tem havido preocupação crescente por parte dos países produtores de flores em realizar controles mais eficazes da temperatura da carga, pois está diretamente relacionada à qualidade da flor e à competitividade desses países no mercado internacional. O investimento na cadeia do frio, desde o produtor até o distribuidor, repercutiria em ganhos no lead time do produto exportado. A etapa mais complicada de se verificar as condições da mercadoria é o processo de distribuição externa via modal aéreo (C), apesar da carga permanecer poucas horas nos aeroportos. Se ocorrerem muitas falhas nos processos, conforme se verificou no Cenário 5, pode comprometer a finalização das negociações e os contratos com os clientes.

Como esse modelo privilegia análise de processos e não dos agentes envolvidos na cadeia, pode-se perceber com mais clareza que não há relações fixas nos relacionamentos. Em cada etapa há custos e receitas envolvidos e dependendo do acordo que se fizer entre as partes poderá haver alocação diferenciada em cada um dos contratos. O processo de produção (A) foi o único que manteve seus lucros unitários brutos e finais fixos, pois se localiza no início da cadeia. O processo de distribuição externa via modal aéreo (C) não agrega valor na cadeia, por isso seus lucros unitários eram sempre negativos ou nulos, dependendo da ocorrência de perdas.

Apesar dos custos logísticos, de maneira geral, representarem parcela significativa dentro das empresas, ficou evidente neste estudo que a má alocação de 
insumos logísticos em cada processo pode acarretar elevação mais acentuada desses custos, diminuindo a flexibilidade da cadeia e até inviabilizando a exportação de flores sob determinadas circunstâncias, conforme verificado nos cenários em que havia déficit logístico, agravado por falhas em processos da cadeia. A cooperativa é um agente importante nessa cadeia, pois como agrega maior número de produtores, pode disponibilizar tecnologias necessárias para garantir a qualidade das flores a custos mais acessíveis aos seus cooperados, funcionando inclusive como um intermediador nas negociações no mercado internacional.

Embora o modelo proposto neste estudo apresentasse alguns cenários para três cadeias de flores distintas - lírio, gérbera 1 e gérbera 2 - com destino ao mercado norteamericano, é importante enfatizar que houve esforço grande na obtenção de informações mais detalhadas dos agentes envolvidos no processo de exportação. Há a possibilidade de estender esse modelo para outras cadeias incorporando outros países de destino e também outros processos, como o de distribuição ao consumidor final (E), que não foi levado em conta neste estudo, por restrição de dados.

Sugere-se para estudos futuros que sejam realizadas análises envolvendo menores períodos de tempo, como mensal ou semestral, para que se avaliem os impactos tanto de curto quanto de longo prazo, facilitando o planejamento da cadeia. Com isso será possível incluir taxa de câmbio real e incorporar a influência da inflação no modelo. Nesse sentido, quanto melhor for o dimensionamento do modelo relacionado ao processo de exportações, mais fácil será entender o papel dos agentes envolvidos em cada etapa. 
ANEXOS 


\section{ANEXO A}

\section{(A) Características do produto (flor de corte)}

1. São produtos:

a)( ) funcionais: satisfazem as necessidades básicas dos consumidores;

b)( ) inovadores: contém inovações de moda ou de tecnologia para que os consumidores tenham uma razão adicional para adquiri-los.

\section{Margem de lucro:}
a) ( ) mais de $60 \%$
c) ( ) 5 a $20 \%$;
b) ( ) 20 a $60 \%$;
d) ( ) menos de $5 \%$.

\section{Ciclo de vida do produto:}
a) ( ) mais de 2 anos;
b) ( ) 1 a 3 anos;
c) ( ) menos de 1 ano.

\section{Margem de contribuição (\%):}
a) ( ) mais de $60 \%$
b) ( ) 40 a $60 \%$;
c) ( ) 20 a $40 \%$
d) ( ) 10 a $20 \%$
e) ( ) 5 a $10 \%$
f) ( ) menos de $5 \%$

5. Variedade do produto:

a) ( ) acima de 100.000 variantes por categoria;

b) ( ) 1.000 a 100.000 variantes por categoria;

c) ( ) 100 a 1.000 variantes por categoria;

d) ( ) 20 a 100 variantes por categoria;

e) ( ) 10 a 20 variantes por categoria.

f) ( ) menos de 10 .

\section{Margem média de erro na previsão da produção:}
a) ( ) 40 a $100 \%$;
b) ( ) 10 a 40\%;
d) ( ) 2 a $5 \%$
e) ( ) menos de $2 \%$
c) ( ) 5 a $10 \%$

7. Taxa média de stockout (quebra ou ruptura de estoque)
a) ( ) mais de $40 \%$;
b) ( ) 10 a $40 \%$;
c) ( ) 5 a $10 \%$
d) ( ) 2 a $5 \%$;
e) ( ) menos de $2 \%$.

8. Prazo de entrega para produtos por pedido:
a) ( ) 1 dia a 2 semanas;
b) ( ) 2 semanas a 1 mês;
c) ( ) 1 mês a 3 meses;
d) ( ) 3 meses a 6 meses;
e) ( ) 6 meses a 1 ano;
f) ( ) 1 ano a 2 anos.

\section{Tipo de demanda:}

a) ( ) Imprevisível (volátil);

b) ( ) Previsível, sem muitas mudanças ao longo do tempo.

\section{Tipo de cadeia de suprimentos:}

a) ( ) Responsiva: há grandes ajustes na sua produção em função da quantidade demandada, manuseio de grande variedade de produtos, produção de produtos inovadores e um nível de serviço muito alto;

b) ( ) Eficiente: prioriza o custo de produzir e entregar um produto ao cliente. 


\section{(B) Questionário: despachante}

1. Com quais integrantes da cadeia se relaciona para realizar a exportação de flores e plantas ornamentais?
a) ( ) Produtores
b) ( ) Cooperativas
c) ( ) Exportadores
d) ( ) outros

2. São realizados contratos com cada um desses integrantes?
a) ( ) Sim. Com qual(is) integrante(s)?
b) ( ) Não

3. Com que freqüência são feitos os pedidos?
a) ( ) diária
b) ( ) semanal
c) ( ) quinzenal
d) ( ) outros. Favor especificar:

4. Qual a freqüência de utilização dos aeroportos para exportação de flores em 2002 e 2003 em porcentagem?

\begin{tabular}{|l|l|c|}
\hline Aeroporto & \% de utilização (base 2002) & \% de utilização (base 2003) \\
\hline a) Viracopos & & \\
\hline $\begin{array}{l}\text { b) Guarulhos } \\
\text { c) Outros }\end{array}$ & & \\
\hline Total & $100 \%$ & $100 \%$ \\
\hline
\end{tabular}

5. Com relação à exportação de flores, quais são os serviços prestados pelo despachante? Como são cobrados?

6. Como são rateadas as despesas com o despachante? São pagas pelo produtor/Cooperativa ou pelo exportador?
a) ( ) Produtor/Cooperativa
c) ( ) Produtor/Cooperativa e exportador

b) ( ) Exportador

d) ( ) outros. Favor especificar:

7. Quanto tempo é gasto, em média, e os atrasos, para realizar cada um dos serviços com destino aos mercados dos EUA e da Europa? 


\section{(C)Questionário: produtores e exportadores}

Descrição das etapas (processos) de exportação e agentes que fazem parte de cada uma delas:

A - produção - produtores, formecedores de insumos

B - distribuliçiçāo interna/modal rodoviário (dentro do pais expodal aéreo - corretores no Brasil e exterior, exportadores, agentes de carga, despachantes/ Brasil e exterior, R. Fed, Min Agric, INFRAERO, importador

D - distribuicão externa/modal rodoviário (dentro do pais importador) - Importadores, corretores, transportadoras no exterior

E - distribuição final - transportadoras, importador, distribuidor, varejista, consumidor final

\begin{tabular}{|c|c|c|c|c|c|c|c|}
\hline \multirow[b]{3}{*}{ Produtos/insumos } & \multirow[b]{3}{*}{ Medidas } & \multicolumn{5}{|c|}{ Processos } & \multirow{3}{*}{$\begin{array}{c}\text { Preço } \\
\text { unitário } \\
\text { médio dos } \\
\text { insumos }\end{array}$} \\
\hline & & $\bar{A}$ & $\bar{B}$ & $\mathrm{C}$ & D & E & \\
\hline & & Produção & $\begin{array}{c}\text { Dist. Interna } \\
\text { rodoviário }\end{array}$ & $\begin{array}{c}\text { Dist. Externa } \\
\text { aéreo }\end{array}$ & $\begin{array}{c}\text { Dist. Externa } \\
\text { rodoviário }\end{array}$ & $\begin{array}{c}\text { Distribuição } \\
\text { Final }\end{array}$ & \\
\hline ** (Manutenção+juros+depreciação) & & & & & & & $(\mathrm{R} \$)$ \\
\hline (A) Produção & Hastes/ano & & & & & & \\
\hline (B) Dist. interna/rodoviário & Hastes/ano & & & & & & \\
\hline (C) Dist. externa/aéreo & Hastes/ano & & & & & & \\
\hline (D) Dist. externa/rodoviário & Hastes/ano & & & & & & \\
\hline (E) dist. Final & Hastes/ano & & & & & & \\
\hline
\end{tabular}

Hastes/ano

(E) dist. Final

e exportação

\begin{tabular}{|l|l|}
\hline Bulbos & Unidades/ano
\end{tabular}

Sementes

Mudas

estoque de bulbos/sementes/mudas

perda de bulbos/sementes/mudas

substrato

Defensivos

Fertilizantes

Caixas plásticas

Equipamento de escritório

Telefone+comunicação

Seguro de veículos

infraestrutura*

estrutura (estufa, viveiro)

plástico*

sombrite $^{\star \star}$

Irrigação*

Eletricidade

Combustível

outros. Especificar:

Unidades/ano

Unidades/ano

dias/safra

\begin{tabular}{l}
\hline$\%$ \\
\hline m/ano
\end{tabular}

Kg/ano

Kg/ano

Unidades/ano

R\$/ano

R\$/ano

$\mathrm{R} \$$ /ano

R\$/ano

R\$/ano

R\$/ano

R\$/ano

R\$/ano

R\$/ano

R $\$$ /ano

R\$/ano

$\mathrm{R} \$$ /ano

\begin{tabular}{|l|l|l|l|l|l|l|}
\hline & & & & & & \\
\hline \\
\end{tabular}

Insumos logísticos

\begin{tabular}{|l|l|l|l|l|l|l|l|}
\hline número de embarques semanais & unidades/semana & & & & \\
\hline
\end{tabular}

tempo de exportação

número de produtos exportados

Tempo de câmara fria

Energia da câmara fria

Câmara fria*

Tempo de Pré-cooling

Pré-cooling ${ }^{* *}$

Tempo de paletização

Paletização*

Temperatura do veículo

Embalagem para exportação

Reserva de espaço aéreo

Desembaraço aduaneiro

Tarifa alfandegária

Sistema de informação

Taxas de comercialização

Perda de flores

anos

unidades

horas/embarque

Kwh/ano

R\$/ano

horas/embarque

R\$/ano

horas/embarque

R\$/ano

$\mathrm{C}$

Unidades/ano

dias/embarque

horas/embarque

R\$/ano

R\$/ano

R\$/ano

Produtos logísticos

\begin{tabular}{l|l}
\hline Bulbos/sementes em estoque & dias/embarque
\end{tabular}

$\%$

Flores em estoque

Ciclo do pedido (tempo efetivo)

Insumos primários

Investimento de capita

Corretor

Despachante aduaneiro

Transporte rodoviário

Transporte aéreo

Avulsos (inclui horas extras

Administrativo

Operacional

Terra/imóvel

\begin{tabular}{|l|l|l|l|l|l|l|}
\hline dias/embarque & & & & & & \\
\hline \\
dias/embarque & & & & & & \\
\hline \\
dias/embarque
\end{tabular}




\section{ANEXO B}

Tabela 9. Principais resultados obtidos das simulações do primeiro cenrio logístico para a cadeia como um todo

\begin{tabular}{|c|c|c|c|c|c|c|c|c|c|c|c|c|}
\hline $\begin{array}{l}\text { Simu- } \\
\text { lação }\end{array}$ & $\begin{array}{l}\text { Núme- } \\
\text { ro de } \\
\text { hastes }\end{array}$ & $\begin{array}{c}\text { Frete } \\
\text { aéreo } \\
\text { (US\$/ } \\
\mathrm{kg} \text { ) }\end{array}$ & $\begin{array}{c}\text { Taxa } \\
\text { câm- } \\
\text { bio } \\
\text { (R\$/ } \\
\text { US\$) }\end{array}$ & $\begin{array}{l}\text { Tipo } \\
\text { de } \\
\text { flor } \\
\end{array}$ & $\begin{array}{l}\text { Custo total } \\
\mathrm{S} / \text { insumo } \\
\text { logístico } \\
\end{array}$ & $\begin{array}{l}\text { Custo total } \\
\mathrm{c} / \text { insumo } \\
\text { logístico }\end{array}$ & $\begin{array}{c}\text { Receita total } \\
\text { s/ produto } \\
\text { logístico }\end{array}$ & $\begin{array}{l}\text { Receita total } \\
\mathrm{c} / \text { produto } \\
\text { logístico }\end{array}$ & $\begin{array}{l}\text { Lucro total } \\
\mathrm{c} / \text { produto } \\
\text { logístico } \\
\end{array}$ & $\begin{array}{l}\text { Lucro total } \\
\mathrm{c} / \text { insumo } \\
\text { logístico } \\
\end{array}$ & $\begin{array}{l}\text { Lucro total } \\
\text { s/ produto } \\
\text { e.insumo } \\
\text { logísticos } \\
\end{array}$ & $\begin{array}{l}\text { Lucro total } \\
\text { c/ insumo } \\
\text { e.produto } \\
\text { logísticos } \\
\end{array}$ \\
\hline 1 & 75 & 1,10 & 1,50 & lírio & $-833.425,20$ & $-1.097 .456,00$ & $1.102 .657,70$ & $1.024 .903,60$ & $191.478,34$ & $5.201,91$ & $269.232,46$ & $-72.552,22$ \\
\hline 2 & 75 & 1,10 & 2,41 & lírio & $-926.785,80$ & $-1.240 .092,00$ & $1.771 .603,40$ & $1.646 .678,40$ & $719.892,56$ & $531.511,51$ & $844.817,53$ & $406.586,55$ \\
\hline 3 & 75 & 1,10 & 3,81 & lírio & $-1.163 .889,00$ & $-1.555 .117,00$ & $2.800 .750,50$ & $2.603 .255,00$ & $1.439 .365,90$ & $1.245 .633,70$ & $1.636 .861,40$ & $1.048 .138,30$ \\
\hline 4 & 75 & 1,25 & 1,50 & lírio & $-833.425,20$ & $-1.098 .673,00$ & $1.102 .657,70$ & $1.024 .903,60$ & $191.478,34$ & $3.984,88$ & $269.232,46$ & $-73.769,25$ \\
\hline 5 & 75 & 1,25 & 2,41 & lírio & $-926.785,80$ & $-1.242 .047,00$ & $1.771 .603,40$ & $1.646 .678,40$ & $719.892,56$ & $529.556,15$ & $844.817,53$ & $404.631,18$ \\
\hline 6 & 75 & 1,25 & 3,81 & lírio & $-1.163 .889,00$ & $-1.558 .208,00$ & $2.800 .750,50$ & $2.603 .255,00$ & $1.439 .365,90$ & $1.242 .542,50$ & $1.636 .861,40$ & $1.045 .047,00$ \\
\hline 7 & 75 & 1,40 & 1,50 & lírio & $-833.425,20$ & $-1.099 .890,00$ & $1.102 .657,70$ & $1.024 .903,60$ & $191.478,34$ & $2.767,85$ & $269.232,46$ & $-74.986,28$ \\
\hline 8 & 75 & 1,40 & 2,41 & lírio & $-926.785,80$ & $-1.244 .003,00$ & $1.771 .603,40$ & $1.646 .678,40$ & $719.892,56$ & $527.600,78$ & $844.817,53$ & $402.675,82$ \\
\hline 9 & 75 & 1,40 & 3,81 & lírio & $-1.163 .889,00$ & $-1.561 .299,00$ & $2.800 .750,50$ & $2.603 .255,00$ & $1.439 .365,90$ & $1.239 .451,20$ & $1.636 .861,40$ & $1.041 .955,70$ \\
\hline 10 & 75 & 1,50 & 1,50 & lírio & $-833.425,20$ & $-1.100 .701,00$ & $1.102 .657,70$ & $1.024 .903,60$ & $191.478,34$ & $1.956,49$ & $269.232,46$ & $-75.797,63$ \\
\hline 11 & 75 & 1,50 & 2,41 & lírio & $-926.785,80$ & $-1.245 .306,00$ & $1.771 .603,40$ & $1.646 .678,40$ & $719.892,56$ & $526.297,21$ & $844.817,53$ & $401.372,24$ \\
\hline 12 & 75 & 1,50 & 3,81 & lírio & $-1.163 .889,00$ & $-1.563 .360,00$ & $2.800 .750,50$ & $2.603 .255,00$ & $1.439 .365,90$ & $1.237 .390,40$ & $1.636 .861,40$ & $1.039 .894,90$ \\
\hline 13 & 80 & 1,10 & 1,50 & lírio & $-833.496,80$ & $-1.087 .977,00$ & $1.102 .657,70$ & $1.024 .903,60$ & $191.406,79$ & $14.680,23$ & $269.160,91$ & $-63.073,89$ \\
\hline 14 & 80 & 1,10 & 2,41 & lírio & $-926.857,40$ & $-1.229 .881,00$ & $1.771 .603,40$ & $1.646 .678,40$ & $719.821,02$ & $541.722,31$ & $844.745,98$ & $416.797,34$ \\
\hline 15 & 80 & 1,10 & 3,81 & lírio & $-1.163 .961,00$ & $-1.543 .779,00$ & $2.800 .750,50$ & $2.603 .255,00$ & $1.439 .294,40$ & $1.256 .971,40$ & $1.636 .789,90$ & $1.059 .475,90$ \\
\hline 16 & 80 & 1,25 & 1,50 & lírio & $-833.496,80$ & $-1.089 .194,00$ & $1.102 .657,70$ & $1.024 .903,60$ & $191.406,79$ & $13.463,20$ & $269.160,91$ & $-64.290,93$ \\
\hline 17 & 80 & 1,25 & 2,41 & lírio & $-926.857,40$ & $-1.231 .836,00$ & $1.771 .603,40$ & $1.646 .678,40$ & $719.821,02$ & $539.766,94$ & $844.745,98$ & $414.841,98$ \\
\hline 18 & 80 & 1,25 & 3,81 & lírio & $-1.163 .961,00$ & $-1.546 .870,00$ & $2.800 .750,50$ & $2.603 .255,00$ & $1.439 .294,40$ & $1.253 .880,20$ & $1.636 .789,90$ & $1.056 .384,70$ \\
\hline 19 & 80 & 1,40 & 1,50 & lírio & $-833.496,80$ & $-1.090 .412,00$ & $1.102 .657,70$ & $1.024 .903,60$ & $191.406,79$ & $12.246,17$ & $269.160,91$ & $-65.507,96$ \\
\hline 20 & 80 & 1,40 & 2,41 & lírio & $-926.857,40$ & $-1.233 .792,00$ & $1.771 .603,40$ & $1.646 .678,40$ & $719.821,02$ & $537.811,58$ & $844.745,98$ & $412.886,61$ \\
\hline 21 & 80 & 1,40 & 3,81 & lírio & $-1.163 .961,00$ & $-1.549 .962,00$ & $2.800 .750,50$ & $2.603 .255,00$ & $1.439 .294,40$ & $1.250 .788,90$ & $1.636 .789,90$ & $1.053 .293,40$ \\
\hline 22 & 80 & 1,50 & 1,50 & lírio & $-833.496,80$ & $-1.091 .223,00$ & $1.102 .657,70$ & $1.024 .903,60$ & 191.406,79 & $11.434,82$ & $269.160,91$ & $-66.319,31$ \\
\hline 23 & 80 & 1,50 & 2,41 & lírio & $-926.857,40$ & $-1.235 .095,00$ & $1.771 .603,40$ & $1.646 .678,40$ & $719.821,02$ & $536.508,00$ & $844.745,98$ & $411.583,04$ \\
\hline
\end{tabular}


Tabela 9. Principais resultados obtidos das simulações do pimeiro cenário logístico para a cadeia como um todo

\begin{tabular}{|c|c|c|c|c|c|c|c|c|c|c|c|c|}
\hline $\begin{array}{l}\text { Simu- } \\
\text { lação }\end{array}$ & $\begin{array}{l}\text { Núme- } \\
\text { ro de } \\
\text { hastes }\end{array}$ & $\begin{array}{c}\text { Frete } \\
\text { aéreo } \\
\text { (US\$/ } \\
\mathrm{kg})\end{array}$ & $\begin{array}{l}\text { Taxa } \\
\text { câm- } \\
\text { bio } \\
\text { (R\$/ } \\
\text { US\$) } \\
\end{array}$ & $\begin{array}{l}\text { Tipo } \\
\text { de } \\
\text { flor }\end{array}$ & $\begin{array}{c}\text { Custo total } \\
\mathrm{s} / \text { insumo } \\
\text { logístico }\end{array}$ & $\begin{array}{l}\text { Custo total } \\
\mathrm{c} / \text { insumo } \\
\text { logístico }\end{array}$ & $\begin{array}{c}\text { Receita total } \\
\mathrm{s} / \text { produto } \\
\text { logístico }\end{array}$ & $\begin{array}{c}\text { Receita total } \\
\mathrm{c} / \text { produto } \\
\text { logístico }\end{array}$ & $\begin{array}{c}\text { Lucro total } \\
\mathrm{c} / \text { produto } \\
\text { logístico }\end{array}$ & $\begin{array}{l}\text { Lucro total } \\
\mathrm{c} / \text { insumo } \\
\text { logístico }\end{array}$ & $\begin{array}{l}\text { Lucro total } \\
\text { s/ produto } \\
\text { e.insumo } \\
\text { logísticos }\end{array}$ & $\begin{array}{l}\text { Lucro total } \\
\text { c/ insumo } \\
\text { e.produto } \\
\text { logísticos }\end{array}$ \\
\hline 24 & 80 & 1,50 & 3,81 & lírio & $-1.163 .961,00$ & $-1.552 .022,00$ & $2.800 .750,50$ & $2.603 .255,00$ & $1.439 .294,40$ & $1.248 .728,10$ & $1.636 .789,90$ & $1.051 .232,60$ \\
\hline 25 & 100 & 1,10 & 1,50 & rio & $-833.711,40$ & $-1.059 .542,00$ & $1.102 .657,70$ & $1.024 .903,60$ & $191.192,14$ & $43.115,20$ & $268.946,27$ & $-34.638,93$ \\
\hline 26 & 100 & 1,10 & 2,41 & lírio & $-927.072,00$ & $-1.199 .249,00$ & $1.771 .603,40$ & $1.646 .678,40$ & $719.606,37$ & $572.354,69$ & $844.531,34$ & $447.429,72$ \\
\hline 27 & 100 & 1,10 & 3,81 & lírio & $-1.164 .175,00$ & $-1.509 .766,00$ & $2.800 .750,50$ & $2.603 .255,00$ & $1.439 .079,70$ & $1.290 .984,40$ & $1.636 .575,20$ & $1.093 .489,00$ \\
\hline 28 & 100 & 1,25 & 1,50 & lírio & $-833.711,40$ & $-1.060 .760,00$ & $1.102 .657,70$ & $1.024 .903,60$ & $191.192,14$ & $41.898,17$ & $268.946,27$ & $-35.855,96$ \\
\hline 29 & 100 & 1,25 & 2,41 & lírio & $-927.072,00$ & $-1.201 .204,00$ & $1.771 .603,40$ & $1.646 .678,40$ & $719.606,37$ & $570.399,32$ & $844.531,34$ & $445.474,36$ \\
\hline 30 & 100 & 1,25 & 3,81 & lírio & $-1.164 .175,00$ & $-1.512 .857,00$ & $2.800 .750,50$ & $2.603 .255,00$ & $1.439 .079,70$ & $1.287 .893,20$ & $1.636 .575,20$ & $1.090 .397,70$ \\
\hline 31 & 100 & 1,40 & 1,50 & lírio & $-833.711,40$ & $-1.061 .977,00$ & $1.102 .657,70$ & $1.024 .903,60$ & $191.192,14$ & $40.681,13$ & $268.946,27$ & $-37.072,99$ \\
\hline 32 & 100 & 1,40 & 2,41 & lírio & $-927.072,00$ & $-1.203 .159,00$ & $1.771 .603,40$ & $1.646 .678,40$ & $719.606,37$ & $568.443,96$ & $844.531,34$ & $443.518,99$ \\
\hline 33 & 100 & 1,40 & 3,81 & lírio & $-1.164 .175,00$ & $-1.515 .949,00$ & $2.800 .750,50$ & $2.603 .255,00$ & $1.439 .079,70$ & $1.284 .801,90$ & $1.636 .575,20$ & $1.087 .306,40$ \\
\hline 34 & 100 & 1,50 & 1,50 & lírio & $-833.711,40$ & $-1.062 .788,00$ & $1.102 .657,70$ & $1.024 .903,60$ & $191.192,14$ & $39.869,78$ & $268.946,27$ & $-37.884,35$ \\
\hline 35 & 100 & 1,50 & 2,41 & lírio & $-927.072,00$ & $-1.204 .463,00$ & $1.771 .603,40$ & $1.646 .678,40$ & $719.606,37$ & $567.140,38$ & $844.531,34$ & $442.215,42$ \\
\hline 36 & 100 & 1,50 & 3,81 & lírio & $-1.164 .175,00$ & $-1.518 .009,00$ & $2.800 .750,50$ & $2.603 .255,00$ & $1.439 .079,70$ & $1.282 .741,10$ & $1.636 .575,20$ & $1.085 .245,60$ \\
\hline 1 & 75 & 1,10 & 1,50 & gérb1 & & & & $138.435,92$ & $-31.039,37$ & $-84.847,37$ & $-20.555,66$ & $-95.331,08$ \\
\hline 2 & 75 & 1,10 & 2,41 & gérb1 & & & & & & $-15.644,27$ & $59.616,65$ & $-32.488,09$ \\
\hline 3 & 75 & 1,10 & 3,81 & & & & $378.255,86$ & 351.62 & $156.330,05$ & $88.708,81$ & $182.958,67$ & $62.080,19$ \\
\hline 4 & 75 & 1,25 & 1,50 & gérb1 & & -234.0 & $148.919,63$ & $138.435,92$ & $-31.039,37$ & $-85.162,91$ & $-20.555,66$ & $-95.646,62$ \\
\hline 5 & 75 & 1,25 & 2,41 & gérb1 & $-179.647,60$ & $-255.415,40$ & $239.264,20$ & $222.420,38$ & $42.772,83$ & $-16.151,23$ & $59.616,65$ & $-32.995,05$ \\
\hline 6 & 75 & 1,25 & 3,81 & gérb1 & $-195.297,20$ & $-290.348,50$ & $378.255,86$ & $351.627,24$ & $156.330,05$ & $87.907,35$ & $182.958,67$ & $61.278,73$ \\
\hline 7 & 75 & 1,40 & 1,50 & gérb1 & $-169.475,30$ & $-234.398,10$ & $148.919,63$ & $138.435,92$ & $-31.039,37$ & $-85.478,44$ & $-20.555,66$ & $-95.962,15$ \\
\hline 8 & 75 & 1,40 & 2,41 & gérb1 & $-179.647,60$ & $-255.922,40$ & $239.264,20$ & $222.420,38$ & $42.772,83$ & $-16.658,19$ & $59.616,65$ & $-33.502,01$ \\
\hline 9 & 75 & 1,40 & 3,81 & gérb1 & $-195.297,20$ & $-291.150,00$ & $378.255,86$ & $351.627,24$ & $156.330,05$ & $87.105,89$ & $182.958,67$ & $60.477,27$ \\
\hline 10 & 75 & 1,50 & 1,50 & gérb1 & $-169.475,30$ & $-234.608,40$ & $148.919,63$ & $138.435,92$ & $-31.039,37$ & $-85.688,80$ & $-20.555,66$ & $-96.172,51$ \\
\hline 11 & 75 & 1,50 & 2,41 & gérb1 & $-179.647,60$ & $-256.260,40$ & $239.264,20$ & $222.420,38$ & $42.772,83$ & $-16.996,16$ & $59.616,65$ & $-33.839,98$ \\
\hline 12 & 75 & 1,50 & 3,81 & gérb1 & $-195.297,20$ & $-291.684,30$ & $378.255,86$ & $351.627,24$ & $156.330,05$ & $86.571,58$ & $182.958,67$ & $59.942,96$ \\
\hline
\end{tabular}


Tabela 9. Principais resultados obtidos das simulações do primeiro cenário logístico para a cadeia como um todo

\begin{tabular}{|c|c|c|c|c|c|c|c|c|c|c|c|c|}
\hline $\begin{array}{l}\text { Simu- } \\
\text { lação }\end{array}$ & $\begin{array}{l}\text { Núme- } \\
\text { ro de } \\
\text { hastes }\end{array}$ & $\begin{array}{c}\text { Frete } \\
\text { aéreo } \\
\text { (US\$/ } \\
\mathrm{kg})\end{array}$ & $\begin{array}{l}\text { Taxa } \\
\text { câm- } \\
\text { bio } \\
\text { (R\$/ } \\
\text { US\$) } \\
\end{array}$ & $\begin{array}{l}\text { Tipo } \\
\text { de } \\
\text { flor }\end{array}$ & $\begin{array}{c}\text { Custo total } \\
\mathrm{s} / \text { insumo } \\
\text { logístico }\end{array}$ & $\begin{array}{l}\text { Custo total } \\
\mathrm{c} / \text { insumo } \\
\text { logístico }\end{array}$ & $\begin{array}{c}\text { Receita total } \\
\mathrm{s} / \text { produto } \\
\text { logístico }\end{array}$ & $\begin{array}{l}\text { Receita total } \\
\mathrm{c} / \text { produto } \\
\text { logístico }\end{array}$ & $\begin{array}{l}\text { Lucro total } \\
\mathrm{c} / \text { produto } \\
\text { logístico }\end{array}$ & $\begin{array}{l}\text { Lucro total } \\
\mathrm{c} / \text { insumo } \\
\text { logístico }\end{array}$ & $\begin{array}{c}\text { Lucro total } \\
\text { s/ produto } \\
\text { e.insumo } \\
\text { logísticos } \\
\end{array}$ & $\begin{array}{l}\text { Lucro total } \\
\text { c/ insumo } \\
\text { e.produto } \\
\text { logísticos }\end{array}$ \\
\hline 13 & 80 & 1,10 & 1,50 & gérb1 & $-169.493,80$ & $-232.385,50$ & $148.919,63$ & $138.435,92$ & $-31.057,92$ & $-83.465,86$ & $-20.574,21$ & $-93.949,57$ \\
\hline 14 & 80 & 1,10 & 2,41 & gérb1 & $-179.666,10$ & $-253.337,10$ & $239.264,20$ & $222.420,38$ & $42.754,28$ & $-14.072,85$ & $59.598,10$ & $-30.916,67$ \\
\hline 15 & 80 & 1,10 & 3,81 & gérb1 & $-195.315,70$ & $-287.683,50$ & $378.255,86$ & $351.627,24$ & $156.311,50$ & $90.572,39$ & $182.940,12$ & $63.943,77$ \\
\hline 16 & 80 & 1,25 & 1,50 & gérb1 & $-169.493,80$ & $-232.701,00$ & $148.919,63$ & $138.435,92$ & $-31.057,92$ & $-83.781,40$ & $-20.574,21$ & $-94.265,11$ \\
\hline 17 & 80 & 1,25 & 2,41 & gérb1 & $-179.666,10$ & $-253.844,00$ & $239.264,20$ & $2.420,38$ & $42.754,28$ & $-14.579,81$ & $59.598,10$ & $-31.423,63$ \\
\hline 18 & 80 & 1,25 & 3,81 & gérb1 & $-195.315,70$ & $-288.484,90$ & $378.255,86$ & $1.627,24$ & $156.311,50$ & $89.770,93$ & $182.940,12$ & $63.142,31$ \\
\hline 19 & 80 & 1,40 & 1,50 & gérb1 & $-169.493,80$ & $-233.016,60$ & $148.919,63$ & $8.435,92$ & $-31.057,92$ & $-84.096,93$ & $-20.574,21$ & $-94.580,64$ \\
\hline 20 & 80 & 1,40 & 2,41 & gérb1 & $-179.666,10$ & $-254.351,00$ & $9.264,20$ & $2.420,38$ & $42.754,28$ & $-15.086,77$ & $59.598,10$ & $-31.930,59$ \\
\hline 21 & 80 & 1,40 & 3,81 & gérb1 & $-195.315,70$ & $-289.286,40$ & $378.255,86$ & $351.627,24$ & $156.311,50$ & $88.969,47$ & $182.940,12$ & $62.340,85$ \\
\hline 22 & 80 & 1,50 & 1,50 & gérb1 & $-169.493,80$ & $-233.226,90$ & $148.919,63$ & $138.435,92$ & $-31.057,92$ & $-84.307,29$ & $-20.574,21$ & $-94.791,00$ \\
\hline 23 & 80 & 1,50 & 2,41 & gérb1 & $-179.666,10$ & $-254.688,90$ & $239.264,20$ & $222.420,38$ & $42.754,28$ & $-15.424,74$ & $59.598,10$ & $-32.268,57$ \\
\hline 24 & 80 & 1,50 & 3,81 & gérb1 & $-195.315,70$ & $-289.820,70$ & $378.255,86$ & $351.627,24$ & $156.311,50$ & $88.435,16$ & $182.940,12$ & $61.806,54$ \\
\hline 25 & 100 & 1,10 & 1,50 & gérb1 & $-169.549,50$ & $-228.241,00$ & $148.919,63$ & $138.435,92$ & $-31.113,57$ & $-79.321,33$ & $-20.629,86$ & $-89.805,04$ \\
\hline 26 & 100 & 1,10 & 2,41 & gérb1 & $-179.721,80$ & $-248.622,80$ & $239.264,20$ & $222.420,38$ & $42.698,63$ & $-9.358,60$ & $59.542,45$ & $-26.202,42$ \\
\hline 27 & 100 & 1,10 & 3,81 & gérb1 & $-195.371,40$ & $-282.092,70$ & $378.255,86$ & $351.627,24$ & $156.255,85$ & $96.163,13$ & $182.884,47$ & $69.534,51$ \\
\hline 28 & 100 & 1,25 & 1,50 & gérb1 & $-169.549,50$ & $-228.556,50$ & $148.919,63$ & $138.435,92$ & $-31.113,57$ & $-79.636,86$ & $-20.629,86$ & $-90.120,57$ \\
\hline 29 & 100 & 1,25 & 2,41 & gérb1 & $-179.721,80$ & $-249.129,80$ & $239.264,20$ & $222.420,38$ & $42.698,63$ & $-9.865,56$ & $59.542,45$ & $-26.709,38$ \\
\hline 30 & 100 & 1,25 & 3,81 & gérb1 & $-195.371,40$ & $-282.894,20$ & $378.255,86$ & $351.627,24$ & $156.255,85$ & $95.361,67$ & $182.884,47$ & $68.733,05$ \\
\hline 31 & 100 & 1,40 & 1,50 & gérb1 & $-169.549,50$ & $-228.872,00$ & $148.919,63$ & $138.435,92$ & $-31.113,57$ & $-79.952,40$ & $-20.629,86$ & $-90.436,11$ \\
\hline 32 & 100 & 1,40 & 2,41 & gérb1 & $-179.721,80$ & $-249.636,70$ & $239.264,20$ & $222.420,38$ & $42.698,63$ & $-10.372,52$ & $59.542,45$ & $-27.216,34$ \\
\hline 33 & 100 & 1,40 & 3,81 & gérb1 & $-195.371,40$ & $-283.695,70$ & $378.255,86$ & $351.627,24$ & $156.255,85$ & $94.560,21$ & $182.884,47$ & $67.931,59$ \\
\hline 34 & 100 & 1,50 & 1,50 & gérb1 & $-169.549,50$ & $-229.082,40$ & $148.919,63$ & & $-31.113,57$ & $-80.162,76$ & $-20.629,86$ & $-90.646,46$ \\
\hline 35 & 100 & 1,50 & 2,41 & gérb1 & $-179.721,80$ & $-249.974,70$ & $239.264,20$ & $222.420,38$ & $42.698,63$ & $-10.710,49$ & $59.542,45$ & $-27.554,32$ \\
\hline 36 & 100 & 1,50 & 3,81 & & $-195.371,40$ & $-284.230,00$ & $378.255,86$ & $351.627,24$ & $156.255,85$ & $94.025,90$ & $182.884,47$ & $67.397,28$ \\
\hline 1 & 75 & 1,10 & 1,50 & gérb2 & $-211.068,80$ & $-363.696,20$ & $384.825,95$ & $357.655,15$ & $146.586,36$ & $21.129,78$ & $173.757,16$ & $-6.041,02$ \\
\hline 2 & 75 & 1,10 & 2,41 & gérb2 & $-228.997,90$ & $-409.747,90$ & $618.287,03$ & $574.632,61$ & $345.634,69$ & $208.539,12$ & $389.289,11$ & $164.884,70$ \\
\hline
\end{tabular}


Tabela 9. Principais resultados obtidos das simulações do primeiro cenário logístico para a cadeia como um todo

\begin{tabular}{|c|c|c|c|c|c|c|c|c|c|c|c|c|}
\hline $\begin{array}{l}\text { Simu- } \\
\text { lação }\end{array}$ & $\begin{array}{l}\text { Núme- } \\
\text { ro de } \\
\text { hastes }\end{array}$ & $\begin{array}{c}\text { Frete } \\
\text { aéreo } \\
\text { (US\$/ } \\
\mathrm{kg})\end{array}$ & $\begin{array}{l}\text { Taxa } \\
\text { câm- } \\
\text { bio } \\
\text { (R\$/ } \\
\text { US\$) }\end{array}$ & $\begin{array}{l}\text { Tipo } \\
\text { de } \\
\text { flor }\end{array}$ & $\begin{array}{l}\text { custo total } \\
\mathrm{s} / \text { insumo } \\
\text { logístico }\end{array}$ & $\begin{array}{l}\text { custo total } \\
\mathrm{c} / \text { insumo } \\
\text { logístico }\end{array}$ & $\begin{array}{c}\text { Receita total } \\
\mathrm{s} / \text { produto } \\
\text { logístico }\end{array}$ & $\begin{array}{l}\text { Receita total } \\
\mathrm{c} / \text { produto } \\
\text { logístico }\end{array}$ & $\begin{array}{l}\text { Lucro total } \\
\mathrm{c} / \text { produto } \\
\text { logístico }\end{array}$ & $\begin{array}{l}\text { Lucro total } \\
\mathrm{c} / \text { insumo } \\
\text { logístico }\end{array}$ & $\begin{array}{l}\text { Lucro total } \\
\text { s/ produto } \\
\text { e.insumo } \\
\text { logísticos } \\
\end{array}$ & $\begin{array}{l}\text { Lucro total } \\
\text { c/ insumo } \\
\text { e.produto } \\
\text { logísticos }\end{array}$ \\
\hline 3 & 75 & 1,10 & 3,81 & gérb2 & $-256.581,20$ & $-482.710,00$ & $977.457,92$ & $908.444,08$ & $651.862,90$ & $494.747,94$ & $720.876,73$ & $425.734,11$ \\
\hline 4 & 75 & 1,25 & 1,50 & gérb2 & $-211.068,80$ & $-364.760,10$ & $384.825,95$ & $357.655,15$ & $146.586,36$ & $20.065,90$ & $173.757,16$ & $-7.104,90$ \\
\hline 5 & 75 & 1,25 & 2,41 & gérb2 & $-228.997,90$ & $-411.457,20$ & $618.287,03$ & $574.632,61$ & $345.634,69$ & $206.829,82$ & $389.289,11$ & $163.175,40$ \\
\hline 6 & 75 & 1,25 & 3,81 & gérb2 & $-256.581,20$ & $-485.412,20$ & $977.457,92$ & $908.444,08$ & $651.862,90$ & $492.045,69$ & $720.876,73$ & $423.031,86$ \\
\hline 7 & 75 & 1,40 & 1,50 & gérb2 & $-211.068,80$ & $-365.823,90$ & $384.825,95$ & $7.655,15$ & $146.586,36$ & $19.002,02$ & $173.757,16$ & $-8.168,78$ \\
\hline 8 & 75 & 1,40 & 2,41 & gérb2 & $-228.997,90$ & $-413.166,50$ & $618.287,03$ & $4.632,61$ & $345.634,69$ & $205.120,53$ & $389.289,11$ & $161.466,10$ \\
\hline 9 & 75 & 1,40 & 3,81 & gérb2 & $-256.581,20$ & $-488.114,50$ & $977.457,92$ & $908.444,08$ & $651.862,90$ & $489.343,44$ & $720.876,73$ & $420.329,60$ \\
\hline 10 & 75 & 1,50 & 1,50 & gérb2 & $-211.068,80$ & $-366.533,20$ & $384.825,95$ & $357.655,15$ & $146.586,36$ & $18.292,77$ & $173.757,16$ & $-8.878,03$ \\
\hline 11 & 75 & 1,50 & 2,41 & gérb2 & $-228.997,90$ & $-414.306,00$ & $618.287,03$ & $574.632,61$ & $345.634,69$ & $203.980,99$ & $389.289,11$ & $160.326,57$ \\
\hline 12 & 75 & 1,50 & 3,81 & gérb2 & $-256.581,20$ & $-489.916,00$ & $977.457,92$ & $908.444,08$ & $651.862,90$ & $487.541,94$ & $720.876,73$ & $418.528,10$ \\
\hline 13 & 80 & 1,10 & 1,50 & gérb2 & $-211.131,30$ & $-358.731,70$ & $384.825,95$ & $357.655,15$ & $146.523,81$ & $26.094,23$ & $173.694,62$ & $-1.076,57$ \\
\hline 14 & 80 & 1,10 & 2,41 & gérb2 & $-229.060,50$ & $-404.143,20$ & $618.287,03$ & $574.632,61$ & $345.572,15$ & $214.143,87$ & $389.226,57$ & $170.489,45$ \\
\hline 15 & 80 & 1,10 & 3,81 & gérb2 & $-256.643,70$ & $-476.120,20$ & $977.457,92$ & $908.444,08$ & $651.800,35$ & $501.337,77$ & $720.814,19$ & $432.323,93$ \\
\hline 16 & 80 & 1,25 & 1,50 & gérb2 & $-211.131,30$ & $-359.795,60$ & $384.825,95$ & $357.655,15$ & $146.523,81$ & $25.030,35$ & $173.694,62$ & $-2.140,45$ \\
\hline 17 & 80 & 1,25 & 2,41 & gérb2 & $-229.060,50$ & $-405.852,50$ & $618.287,03$ & $574.632,61$ & $345.572,15$ & $212.434,57$ & $389.226,57$ & $168.780,15$ \\
\hline 18 & 80 & 1,25 & 3,81 & gérb2 & $-256.643,70$ & $-478.822,40$ & $977.457,92$ & $908.444,08$ & $651.800,35$ & $498.635,52$ & $720.814,19$ & $429.621,68$ \\
\hline 19 & 80 & 1,40 & 1,50 & gérb2 & $-211.131,30$ & $-360.859,50$ & $384.825,95$ & $357.655,15$ & $146.523,81$ & $23.966,48$ & $173.694,62$ & $-3.204,33$ \\
\hline 20 & 80 & 1,40 & 2,41 & gérb2 & $-229.060,50$ & $-407.561,80$ & $618.287,03$ & $574.632,61$ & $345.572,15$ & $210.725,28$ & $389.226,57$ & $167.070,85$ \\
\hline 21 & 80 & 1,40 & 3,81 & gérb2 & $-256.643,70$ & $-481.524,70$ & $977.457,92$ & $908.444,08$ & $651.800,35$ & $495.933,27$ & $720.814,19$ & $426.919,43$ \\
\hline 22 & 80 & 1,50 & 1,50 & gérb2 & $-211.131,30$ & $-361.568,70$ & $384.825,95$ & $357.655,15$ & $146.523,81$ & $23.257,22$ & $173.694,62$ & $-3.913,58$ \\
\hline 23 & 80 & 1,50 & 2,41 & gérb2 & $-229.060,50$ & $-408.701,30$ & $618.287,03$ & $574.632,61$ & $345.572,15$ & $209.585,74$ & $389.226,57$ & $165.931,32$ \\
\hline 24 & 80 & 1,50 & 3,81 & gérb2 & $-256.643,70$ & $-483.326,20$ & $977.457,92$ & $908.444,08$ & $651.800,35$ & $494.131,76$ & $720.814,19$ & $425.117,93$ \\
\hline 25 & 100 & 1,10 & 1,50 & gérb2 & $-211.319,00$ & $-343.838,40$ & $384.825,95$ & $357.655,15$ & $146.336,18$ & $40.987,59$ & $173.506,98$ & $13.816,79$ \\
\hline 26 & 100 & 1,10 & 2,41 & gérb2 & $-229.248,10$ & $-387.328,90$ & $618.287,03$ & $574.632,61$ & $345.384,51$ & $230.958,12$ & $389.038,94$ & $187.303,70$ \\
\hline 27 & 100 & 1,10 & 3,81 & gérb2 & $-256.831,40$ & $-456.350,70$ & $977.457,92$ & $908.444,08$ & $651.612,72$ & $521.107,23$ & $720.626,56$ & $452.093,39$ \\
\hline 28 & 100 & 1,25 & 1,50 & gérb2 & $-211.319,00$ & $-344.902,20$ & $384.825,95$ & $357.655,15$ & $146.336,18$ & $39.923,71$ & $173.506,98$ & $12.752,91$ \\
\hline
\end{tabular}


Tabela 9. Principais resultados obtidos das simulações do primeiro cenário logístico para a cadeia como um todo

\begin{tabular}{|c|c|c|c|c|c|c|c|c|c|c|c|c|}
\hline $\begin{array}{l}\text { Simu- } \\
\text { Lação }\end{array}$ & $\begin{array}{l}\text { Núme- } \\
\text { ro de } \\
\text { hastes }\end{array}$ & $\begin{array}{c}\text { Frete } \\
\text { aéreo } \\
\text { (US\$/ } \\
\mathrm{kg})\end{array}$ & $\begin{array}{l}\text { taxa } \\
\text { câm- } \\
\text { bio } \\
\text { (R\$/ } \\
\text { US\$) } \\
\end{array}$ & $\begin{array}{l}\text { Tipo } \\
\text { de } \\
\text { flor }\end{array}$ & $\begin{array}{l}\text { custo total } \\
\mathrm{s} / \text { insumo } \\
\text { logístico }\end{array}$ & $\begin{array}{l}\text { custo total } \\
\mathrm{c} / \text { insumo } \\
\text { logístico }\end{array}$ & $\begin{array}{l}\text { Receita total } \\
\mathrm{s} / \text { produto } \\
\text { logístico }\end{array}$ & $\begin{array}{l}\text { Receita total } \\
\mathrm{c} / \text { produto } \\
\text { logístico }\end{array}$ & $\begin{array}{l}\text { Lucro total } \\
\mathrm{c} / \text { produto } \\
\text { logístico }\end{array}$ & $\begin{array}{l}\text { Lucro total } \\
\mathrm{c} / \text { insumo } \\
\text { logístico }\end{array}$ & $\begin{array}{l}\text { Lucro total } \\
\text { s/ produto } \\
\text { e.insumo } \\
\text { logísticos }\end{array}$ & $\begin{array}{l}\text { Lucro total } \\
\text { c/ insumo } \\
\text { e.produto } \\
\text { logísticos }\end{array}$ \\
\hline 29 & 100 & 1,25 & 2,41 & gérb2 & $-229.248,10$ & $-389.038,20$ & $618.287,03$ & $574.632,61$ & $345.384,51$ & $229.248,82$ & $389.038,94$ & $185.594,40$ \\
\hline 30 & 100 & 1,25 & 3,81 & gérb2 & $-256.831,40$ & $-459.052,90$ & $977.457,92$ & $908.444,08$ & $651.612,72$ & $518.404,98$ & $720.626,56$ & $449.391,14$ \\
\hline 31 & 100 & 1,40 & 1,50 & gérb2 & $-211.319,00$ & $-345.966,10$ & $384.825,95$ & $357.655,15$ & $146.336,18$ & $38.859,83$ & $173.506,98$ & $11.689,03$ \\
\hline 32 & 100 & 1,40 & 2,41 & gérb2 & $-229.248,10$ & $-390.747,50$ & $618.287,03$ & $574.632,61$ & $345.384,51$ & $227.539,52$ & $389.038,94$ & $183.885,10$ \\
\hline 33 & 100 & 1,40 & 3,81 & gérb2 & -256.831 & $-461.755,20$ & $977.457,92$ & $908.444,08$ & $651.612,72$ & $515.702,73$ & $720.626,56$ & $446.688,89$ \\
\hline 34 & 100 & 1,50 & 1,50 & gérb2 & $-211.319,00$ & $-346.675,40$ & $384.825,95$ & $357.655,15$ & $146.336,18$ & $38.150,58$ & $173.506,98$ & $10.979,78$ \\
\hline 35 & 100 & 1,50 & 2,41 & gérb2 & $-229.248,10$ & $-391.887,00$ & $618.287,03$ & $574.632,61$ & $345.384,51$ & $226.399,99$ & $389.038,94$ & $182.745,57$ \\
\hline 36 & 100 & 1,50 & 3,81 & gérb2 & $-256.831,40$ & $-463.556,70$ & $977.457,92$ & $908.444,08$ & $651.612,72$ & $513.901,23$ & $720.626,56$ & $444.887,39$ \\
\hline
\end{tabular}


Tabela 10. Principais resultados obtidos das simulações do segundo cenário logístico para a cadeia como um todo

\begin{tabular}{|c|c|c|c|c|c|c|c|c|c|c|c|c|}
\hline $\begin{array}{l}\text { Simu- } \\
\text { Lação }\end{array}$ & $\begin{array}{l}\text { Núme- } \\
\text { ro de } \\
\text { hastes }\end{array}$ & $\begin{array}{c}\text { Frete } \\
\text { aéreo } \\
\text { (US\$/ } \\
\mathrm{kg} \text { ) } \\
\end{array}$ & $\begin{array}{c}\text { taxa } \\
\text { câm- } \\
\text { bio } \\
\text { (R\$/ } \\
\text { US\$) } \\
\end{array}$ & $\begin{array}{l}\text { Tipo } \\
\text { de } \\
\text { flor } \\
\end{array}$ & $\begin{array}{c}\text { custo total } \\
\mathrm{s} / \text { insumo } \\
\text { logístico }\end{array}$ & $\begin{array}{l}\text { custo total } \\
\mathrm{c} / \text { insumo } \\
\text { logístico }\end{array}$ & $\begin{array}{c}\text { Receita total } \\
\mathrm{s} / \text { produto } \\
\text { logístico }\end{array}$ & $\begin{array}{c}\text { Receita total } \\
\mathrm{c} / \text { produto } \\
\text { logístico }\end{array}$ & $\begin{array}{c}\text { Lucro total } \\
\mathrm{c} / \text { produto } \\
\text { logístico }\end{array}$ & $\begin{array}{c}\text { Lucro total } \\
\mathrm{c} / \text { insumo } \\
\text { logístico }\end{array}$ & $\begin{array}{c}\text { Lucro total } \\
\text { s/ produto } \\
\text { e.insumo } \\
\text { logísticos }\end{array}$ & $\begin{array}{l}\text { Lucro total } \\
\text { c/ insumo } \\
\text { e.produto } \\
\text { logísticos }\end{array}$ \\
\hline 1 & 75 & 1,10 & 1,50 & lírio & $-836.587,60$ & $-1.111 .143,00$ & $1.157 .790,60$ & $1.076 .148,70$ & $239.561,09$ & $46.647,24$ & $321.202,93$ & $-34.994,59$ \\
\hline 2 & 75 & 1,10 & 2,41 & lírio & $-931.901,50$ & $1.258 .069,00$ & $1.860 .183,50$ & $1.729 .012,30$ & $797.110,80$ & $602.114,51$ & $928.282,01$ & $470.943,29$ \\
\hline 3 & 75 & 1,10 & 3,81 & lírio & $-1.172 .010,00$ & $1.579 .693,00$ & $2.940 .788,10$ & $2.733 .417,80$ & $1.561 .408,00$ & $1.361 .094,70$ & $1.768 .778,20$ & $1.153 .724,40$ \\
\hline 4 & 75 & 1,25 & 1,50 & lírio & $836.587,60$ & $1.112 .421,00$ & $1.157 .790,60$ & $1.076 .148,70$ & $239.561,09$ & $45.369,36$ & $321.202,93$ & $-36.272,48$ \\
\hline 5 & 75 & 1,25 & 2,41 & lírio & $931.901,50$ & 22,00 & $1.860 .183,50$ & $.729 .012,30$ & $7.110,80$ & $600.061,37$ & $928.282,01$ & $468.890,16$ \\
\hline 6 & 75 & 1,25 & 3,81 & lírio & $172.010,00$ & $1.582 .939,00$ & $2.940 .788,10$ & $.733 .417,80$ & 1.561 .40 & $1.357 .848,90$ & $1.768 .778,20$ & $1.150 .478,60$ \\
\hline 7 & 75 & 1,40 & 1,50 & lírio & $36.587,60$ & $-1.113 .699,00$ & $1.157 .790,60$ & $.076 .148,70$ & $39.561,09$ & $44.091,48$ & $321.202,93$ & $-37.550,36$ \\
\hline 8 & 75 & 1,40 & 2,41 & lírio & $-931.901,50$ & $-1.262 .175,00$ & $1.860 .183,50$ & $.729 .012,30$ & $797.110,80$ & $598.008,24$ & $928.282,01$ & $466.837,03$ \\
\hline 9 & 75 & 1,40 & 3,81 & lírio & $-1.172 .010,00$ & $-1.586 .185,00$ & $2.940 .788,10$ & $2.733 .417,80$ & $1.561 .408,00$ & $1.354 .603,00$ & $1.768 .778,20$ & $1.147 .232,80$ \\
\hline 10 & 75 & 1,50 & 1,50 & lírio & $-836.587,60$ & $-1.114 .551,00$ & $1.157 .790,60$ & $1.076 .148,70$ & $239.561,09$ & $43.239,55$ & $321.202,93$ & $-38.402,28$ \\
\hline 11 & 75 & 1,50 & 2,41 & lírio & $-931.901,50$ & $-1.263 .544,00$ & $1.860 .183,50$ & $1.729 .012,30$ & $797.110,80$ & $596.639,49$ & $928.282,01$ & $465.468,27$ \\
\hline 12 & 75 & 1,50 & 3,81 & lírio & $-1.172 .010,00$ & $-1.588 .349,00$ & $2.940 .788,10$ & $2.733 .417,80$ & $1.561 .408,00$ & $1.352 .439,20$ & $1.768 .778,20$ & $1.145 .068,90$ \\
\hline 13 & 80 & 1,10 & 1,50 & lírio & $-836.662,80$ & $-1.101 .191,00$ & $1.157 .790,60$ & $1.076 .148,70$ & $239.485,97$ & $56.599,48$ & $321.127,80$ & $-25.042,36$ \\
\hline 14 & 80 & 1,10 & 2,41 & lírio & $-931.976,60$ & $-1.247 .348,00$ & $1.860 .183,50$ & $1.729 .012,30$ & $797.035,68$ & $612.835,84$ & $928.206,89$ & $481.664,63$ \\
\hline 15 & 80 & 1,10 & 3,81 & lírio & $-1.172 .085,00$ & $-1.567 .789,00$ & $2.940 .788,10$ & $2.733 .417,80$ & $1.561 .332,90$ & $1.372 .999,20$ & $1.768 .703,10$ & $1.165 .629,00$ \\
\hline 16 & 80 & 1,25 & 1,50 & lírio & $-836.662,80$ & $-1.102 .469,00$ & $1.157 .790,60$ & $1.076 .148,70$ & $239.485,97$ & $55.321,60$ & $321.127,80$ & $-26.320,24$ \\
\hline 17 & 80 & 1,25 & 2,41 & lírio & $-931.976,60$ & $-1.249 .401,00$ & $1.860 .183,50$ & $1.729 .012,30$ & $797.035,68$ & $610.782,71$ & $928.206,89$ & $479.611,50$ \\
\hline 18 & 80 & 1,25 & 3,81 & lírio & $-1.172 .085,00$ & $-1.571 .035,00$ & $2.940 .788,10$ & $2.733 .417,80$ & $1.561 .332,90$ & $1.369 .753,40$ & $1.768 .703,10$ & $1.162 .383,20$ \\
\hline 19 & 80 & 1,40 & 1,50 & lírio & $-836.662,80$ & $-1.103 .747,00$ & $1.157 .790,60$ & $1.076 .148,70$ & $239.485,97$ & $54.043,71$ & $321.127,80$ & $-27.598,12$ \\
\hline 20 & 80 & 1,40 & 2,41 & lírio & $31.976,60$ & $-1.251 .454,00$ & $1.860 .183,50$ & $1.729 .012,30$ & $797.035,68$ & $608.729,58$ & $928.206,89$ & $477.558,36$ \\
\hline 21 & 80 & 1,40 & 3,81 & lírio & $-1.172 .085,00$ & $-1.574 .280,00$ & $2.940 .788,10$ & $2.733 .417,80$ & $1.561 .332,90$ & $1.366 .507,60$ & $1.768 .703,10$ & $1.159 .137,30$ \\
\hline 22 & 80 & 1,50 & 1,50 & lírio & $336.662,80$ & $-1.104 .599,00$ & $1.157 .790,60$ & $1.076 .148,70$ & $239.485,97$ & $53.191,79$ & $321.127,80$ & $-28.450,04$ \\
\hline 23 & 80 & 1,50 & 2,41 & lírio & $-931.976,60$ & $-1.252 .823,00$ & $1.860 .183,50$ & $1.729 .012,30$ & $797.035,68$ & $607.360,82$ & $928.206,89$ & $476.189,61$ \\
\hline 24 & 80 & 1,50 & 3,81 & lírio & $-1.172 .085,00$ & $-1.576 .444,00$ & $2.940 .788,10$ & $2.733 .417,80$ & $1.561 .332,90$ & $1.364 .343,70$ & $1.768 .703,10$ & $1.156 .973,50$ \\
\hline 25 & 100 & 1,10 & 1,50 & lírio & $-836.888,10$ & $-1.071 .334,00$ & $1.157 .790,60$ & $1.076 .148,70$ & $239.260,59$ & $86.456,19$ & $320.902,42$ & $4.814,36$ \\
\hline 26 & 100 & 1,10 & 2,41 & lírio & $-932.202,00$ & $-1.215 .184,00$ & $1.860 .183,50$ & $1.729 .012,30$ & $796.810,30$ & $644.999,84$ & $927.981,51$ & $513.828,63$ \\
\hline
\end{tabular}


Tabela 10. Principais resultados obtidos das simulações do segundo cenário logístico para a cadeia como um todo

\begin{tabular}{|c|c|c|c|c|c|c|c|c|c|c|c|c|}
\hline $\begin{array}{l}\text { Simu- } \\
\text { Lação }\end{array}$ & $\begin{array}{l}\text { Núme- } \\
\text { ro de } \\
\text { hastes }\end{array}$ & $\begin{array}{c}\text { Frete } \\
\text { aéreo } \\
\text { (US\$/ } \\
\mathrm{kg} \text { ) }\end{array}$ & $\begin{array}{l}\text { taxa } \\
\text { câm- } \\
\text { bio } \\
\text { (R\$/ } \\
\text { US\$) } \\
\end{array}$ & $\begin{array}{l}\text { Tipo } \\
\text { de } \\
\text { flor }\end{array}$ & $\begin{array}{c}\text { custo total } \\
\mathrm{s} / \text { insumo } \\
\text { logístico }\end{array}$ & $\begin{array}{l}\text { custo total } \\
\mathrm{c} / \text { insumo } \\
\text { logístico } \\
\end{array}$ & $\begin{array}{l}\text { Receita total } \\
\mathrm{s} / \text { produto } \\
\text { logístico }\end{array}$ & $\begin{array}{l}\text { Receita total } \\
\mathrm{c} / \text { produto } \\
\text { logístico }\end{array}$ & $\begin{array}{l}\text { Lucro total } \\
\mathrm{c} / \text { produto } \\
\text { logístico }\end{array}$ & $\begin{array}{l}\text { Lucro total } \\
\mathrm{c} / \text { insumo } \\
\text { logístico } \\
\end{array}$ & $\begin{array}{l}\text { Lucro total } \\
\mathrm{S} / \text { produto } \\
\text { e.insumo } \\
\text { logísticos }\end{array}$ & $\begin{array}{l}\text { Lucro total } \\
\text { c/ insumo } \\
\text { e.produto } \\
\text { logísticos }\end{array}$ \\
\hline 27 & 100 & 1,10 & 3,81 & lírio & $-1.172 .310,00$ & $-1.532 .075,00$ & $2.940 .788,10$ & $2.733 .417,80$ & $1.561 .107,50$ & $1.408 .712,90$ & $1.768 .477,70$ & $1.201 .342,70$ \\
\hline 28 & 100 & 1,25 & 1,50 & lírio & $-836.888,10$ & $-1.072 .612,00$ & $1.157 .790,60$ & $1.076 .148,70$ & $239.260,59$ & $85.178,31$ & $320.902,42$ & $3.536,47$ \\
\hline 29 & 100 & 1,25 & 2,41 & lírio & $-932.202,00$ & $-1.217 .237,00$ & $1.860 .183,50$ & $1.729 .012,30$ & $796.810,30$ & $642.946,71$ & $927.981,51$ & $511.775,50$ \\
\hline 30 & 100 & 1,25 & 3,81 & lírio & & & $2.940 .788,10$ & & & & & \\
\hline 31 & 100 & 1,40 & 1,50 & lírio & & & & & & & & \\
\hline 32 & 100 & 1,40 & 2,41 & lírio & & & $1.860 .183,50$ & & & $640.893,58$ & $27.981,51$ & $509.722,36$ \\
\hline 33 & 100 & 1,40 & 3,81 & lírio & $-1.172 .310,00$ & $-1.538 .567,00$ & $2.940 .788,10$ & $2.733 .417,80$ & $1.561 .107,50$ & $1.402 .221,30$ & $1.768 .477,70$ & $1.194 .851,00$ \\
\hline 34 & 100 & 1,50 & 1,50 & lírio & & $-1.074 .742,00$ & $1.157 .790,60$ & $1.076 .148,70$ & $239.260,59$ & $83.048,50$ & $320.902,42$ & $1.406,67$ \\
\hline 35 & 100 & 1,50 & 2,41 & lírio & $-932.202,00$ & $-1.220 .659,00$ & $1.860 .183,50$ & $1.729 .012,30$ & $796.810,30$ & $639.524,82$ & $927.981,51$ & $508.353,61$ \\
\hline 36 & 100 & 1,50 & 3,81 & lírio & $-1.172 .310,00$ & $-1.540 .731,00$ & $2.940 .788,10$ & $2.733 .417,80$ & $1.561 .107,50$ & $1.400 .057,40$ & $1.768 .477,70$ & $1.192 .687,10$ \\
\hline 1 & 75 & 1,10 & 1,50 & gérb1 & $-169.895,00$ & $-235.750,30$ & $156.365,61$ & $145.357,72$ & $-24.537,26$ & $-79.384,73$ & $-13.529,36$ & $-90.392,62$ \\
\hline 2 & 75 & 1,10 & 2,41 & gérb1 & $-180.330,90$ & $-257.576,50$ & $251.227,41$ & $233.541,40$ & $53.210,55$ & $-6.349,05$ & $70.896,56$ & $-24.035,07$ \\
\hline 3 & 75 & 1,10 & 3,81 & gérb1 & $-196.386,10$ & $-293.268,40$ & $397.168,65$ & $369.208,60$ & $172.822,55$ & $103.900,29$ & $200.782,60$ & $75.940,24$ \\
\hline 4 & 75 & 1,25 & 1,50 & gérb1 & $-169.895,00$ & $-236.081,70$ & $156.365,61$ & $145.357,72$ & $-24.537,26$ & $-79.716,04$ & $-13.529,36$ & $-90.723,94$ \\
\hline 5 & 75 & 1,25 & 2,41 & gérb1 & $-180.330,90$ & $-258.108,80$ & $251.227,41$ & $233.541,40$ & $53.210,55$ & $-6.881,36$ & $70.896,56$ & $-24.567,37$ \\
\hline 6 & 75 & 1,25 & 3,81 & gérb1 & $-196.386,10$ & $-294.109,90$ & $397.168,65$ & $369.208,60$ & $172.822,55$ & $103.058,76$ & $200.782,60$ & $75.098,71$ \\
\hline 7 & 75 & 1,40 & 1,50 & gérb1 & $-169.895,00$ & $-236.413,00$ & $156.365,61$ & $145.357,72$ & $-24.537,26$ & $-80.047,35$ & $-13.529,36$ & $-91.055,25$ \\
\hline 8 & 75 & 1,40 & 2,41 & gérb1 & $-180.330,90$ & $-258.641,10$ & $251.227,41$ & $233.541,40$ & $53.210,55$ & $-7.413,67$ & $70.896,56$ & $-25.099,68$ \\
\hline 9 & 75 & 1,40 & 3,81 & gérb1 & $-196.386,10$ & $-294.951,40$ & $397.168,65$ & $369.208,60$ & $172.822,55$ & $102.217,22$ & $200.782,60$ & $74.257,17$ \\
\hline 10 & 75 & 1,50 & 1,50 & gérb1 & $-169.895,00$ & $-236.633,80$ & $156.365,61$ & $145.357,72$ & $-24.537,26$ & $-80.268,23$ & $-13.529,36$ & $-91.276,12$ \\
\hline 11 & 75 & 1,50 & 2,41 & gérb1 & $-180.330,90$ & $-258.996,00$ & $251.227,41$ & $233.541,40$ & $53.210,55$ & $-7.768,54$ & $70.896,56$ & $-25.454,56$ \\
\hline 12 & 75 & 1,50 & 3,81 & gérb1 & & & & & $172.822,55$ & $101.656,20$ & $200.782,60$ & $73.696,15$ \\
\hline 13 & 80 & 1,10 & 1,50 & gérb1 & & & & & & $-77.934,14$ & & $-88.942,04$ \\
\hline 14 & 80 & 1,10 & 2,41 & gérb1 & & $-255.926,50$ & & & & $-4.699,06$ & $70.877,08$ & $-22.385,08$ \\
\hline 15 & 80 & 1,10 & 3,81 & gérb1 & $-196.405,50$ & $-291.311,60$ & $397.168,65$ & $369.208,60$ & $172.803,07$ & $105.857,05$ & $200.763,12$ & $77.897,00$ \\
\hline 16 & 80 & 1,25 & 1,50 & gérb1 & $-169.914,50$ & $-234.631,10$ & $156.365,61$ & $145.357,72$ & $-24.556,73$ & $-78.265,46$ & $-13.548,84$ & $-89.273,35$ \\
\hline
\end{tabular}


Tabela 10. Principais resultados obtidos das simulações do segundo cenário logístico para a cadeia como um todo

\begin{tabular}{|c|c|c|c|c|c|c|c|c|c|c|c|c|}
\hline $\begin{array}{l}\text { Simu- } \\
\text { Lação }\end{array}$ & $\begin{array}{l}\text { Núme- } \\
\text { ro de } \\
\text { hastes }\end{array}$ & $\begin{array}{c}\text { Frete } \\
\text { aéreo } \\
\text { (US\$/ } \\
\mathrm{kg} \text { ) }\end{array}$ & $\begin{array}{l}\text { taxa } \\
\text { câm- } \\
\text { bio } \\
\text { (R\$/ } \\
\text { US\$) } \\
\end{array}$ & $\begin{array}{l}\text { Tipo } \\
\text { de } \\
\text { flor }\end{array}$ & $\begin{array}{l}\text { custo total } \\
\text { s/ insumo } \\
\text { logístico }\end{array}$ & $\begin{array}{l}\text { custo total } \\
\mathrm{c} / \text { insumo } \\
\text { logístico }\end{array}$ & $\begin{array}{c}\text { Receita total } \\
\mathrm{s} / \text { produto } \\
\text { logístico }\end{array}$ & $\begin{array}{c}\text { Receita total } \\
\mathrm{c} / \text { produto } \\
\text { logístico }\end{array}$ & $\begin{array}{c}\text { Lucro total } \\
\mathrm{c} / \text { produto } \\
\text { logístico }\end{array}$ & $\begin{array}{l}\text { Lucro total } \\
\mathrm{c} / \text { insumo } \\
\text { logístico }\end{array}$ & $\begin{array}{c}\text { Lucro total } \\
\text { s/ produto } \\
\text { e.insumo } \\
\text { logísticos }\end{array}$ & $\begin{array}{l}\text { Lucro total } \\
\mathrm{c} / \text { insumo } \\
\text { e.produto } \\
\text { logísticos }\end{array}$ \\
\hline 17 & 80 & 1,25 & 2,41 & gérb1 & $-180.350,30$ & $-256.458,80$ & $251.227,41$ & $233.541,40$ & $53.191,07$ & $-5.231,37$ & $70.877,08$ & $-22.917,39$ \\
\hline 18 & 80 & 1,25 & 3,81 & gérb1 & $-196.405,50$ & $-292.153,10$ & $397.168,65$ & $369.208,60$ & $172.803,07$ & $105.015,51$ & $200.763,12$ & $77.055,47$ \\
\hline 19 & 80 & 1,40 & 1,50 & gérb1 & $-169.914,50$ & $-234.962,40$ & $156.365,61$ & $145.357,72$ & $-24.556,73$ & $-78.596,77$ & $-13.548,84$ & $-89.604,66$ \\
\hline 20 & 80 & 1,40 & 2,41 & gérb1 & $-180.350,30$ & $-256.991,10$ & $251.227,41$ & $233.541,40$ & $53.191,07$ & $-5.763,68$ & $70.877,08$ & $-23.449,70$ \\
\hline 21 & 80 & 1,40 & 3,81 & gérb1 & $-196.405,50$ & $-292.994,70$ & $397.168,65$ & $369.208,60$ & $172.803,07$ & $104.173,98$ & $200.763,12$ & $76.213,93$ \\
\hline 22 & 80 & 1,50 & 1,50 & gérb1 & $-169.914,50$ & $-235.183,30$ & $156.365,61$ & $145.357,72$ & $-24.556,73$ & $-78.817,64$ & $-13.548,84$ & $-89.825,54$ \\
\hline 23 & 80 & 1,50 & 2,41 & gérb1 & $-180.350,30$ & $-257.346,00$ & $251.227,41$ & $233.541,40$ & $53.191,07$ & $-6.118,55$ & $70.877,08$ & $-23.804,57$ \\
\hline 24 & 80 & 1,50 & 3,81 & gérb1 & $-196.405,50$ & $-293.555,70$ & $397.168,65$ & $369.208,60$ & $172.803,07$ & $103.612,96$ & $200.763,12$ & $75.652,91$ \\
\hline 25 & 100 & 1,10 & 1,50 & gérb1 & $-169.972,90$ & $-229.948,00$ & $156.365,61$ & $145.357,72$ & $-24.615,17$ & $-73.582,38$ & $-13.607,27$ & $-84.590,28$ \\
\hline 26 & 100 & 1,10 & 2,41 & gérb1 & $-180.408,80$ & $-250.976,50$ & $251.227,41$ & $3.541,40$ & $53.132,64$ & 250,90 & $70.818,65$ & $-17.435,12$ \\
\hline 27 & 100 & 1,10 & 3,81 & gérb1 & $-196.464,00$ & $-285.441,30$ & $397.168,65$ & $369.208,60$ & $172.744,64$ & $111.727,32$ & $200.704,69$ & $83.767,27$ \\
\hline 28 & 100 & 1,25 & 1,50 & gérb1 & $-169.972,90$ & $-230.279,30$ & $156.365,61$ & $145.357,72$ & $-24.615,17$ & $-73.913,70$ & $-13.607,27$ & $-84.921,59$ \\
\hline 29 & 100 & 1,25 & 2,41 & gérb1 & $-180.408,80$ & $-251.508,80$ & $251.227,41$ & $233.541,40$ & $53.132,64$ & $-281,41$ & $70.818,65$ & $-17.967,42$ \\
\hline 30 & 100 & 1,25 & 3,81 & gérb1 & $-196.464,00$ & $-286.282,90$ & $397.168,65$ & $369.208,60$ & $172.744,64$ & $110.885,79$ & $200.704,69$ & $82.925,74$ \\
\hline 31 & 100 & 1,40 & 1,50 & gérb1 & -169.9 & & & & &, 01 & & $-85.252,90$ \\
\hline 32 & 100 & 1,40 & 2,41 & gérl & & & & & $53.132,64$ & $-813,72$ & $70.818,65$ & $-18.499,73$ \\
\hline 33 & 100 & 1,40 & 3,81 & & $-196.464,00$ & $-287.124,40$ & $397.168,65$ & $369.208,60$ & $172.744,64$ & $110.044,26$ & $200.704,69$ & $82.084,21$ \\
\hline 34 & 100 & 1,50 & 1,50 & gérb1 & $-169.972,90$ & $-230.831,50$ & $156.365,61$ & $145.357,72$ & $-24.615,17$ & $-74.465,88$ & $-13.607,27$ & $-85.473,78$ \\
\hline 35 & 100 & 1,50 & 2,41 & gérb1 & $-180.408,80$ & $-252.396,00$ & $251.227,41$ & $233.541,40$ & $53.132,64$ & $-1.168,59$ & $70.818,65$ & $-18.854,60$ \\
\hline 36 & 100 & 1,50 & 3,81 & gérb1 & $-196.464,00$ & $-287.685,40$ & $397.168,65$ & $369.208,60$ & $172.744,64$ & $109.483,23$ & $200.704,69$ & $81.523,19$ \\
\hline 1 & 75 & 1,10 & 1,50 & gérb2 & $-212.193,10$ & $-370.383,60$ & $405.079,95$ & $376.479,11$ & $164.286,05$ & $34.696,34$ & $192.886,89$ & $6.095,49$ \\
\hline 2 & 75 & 1,10 & 2,41 & gérb2 & $-230.836,20$ & $-418.495,40$ & $650.828,45$ & $604.876,43$ & $374.040,24$ & $232.333,08$ & $419.992,27$ & $186.381,06$ \\
\hline 3 & 75 & 1,10 & 3,81 & gérb2 & $-259.517,90$ & $-494.626,70$ & $1.028 .903,10$ & $956.256,93$ & $696.739,00$ & $534.276,38$ & $769.385,15$ & $461.630,23$ \\
\hline 4 & 75 & 1,25 & 1,50 & gérb2 & $-212.193,10$ & $-371.503,50$ & $405.079,95$ & $376.479,11$ & $164.286,05$ & $33.576,46$ & $192.886,89$ & $4.975,62$ \\
\hline 5 & 75 & 1,25 & 2,41 & gérb2 & $-230.836,20$ & $-420.294,60$ & $650.828,45$ & $604.876,43$ & $374.040,24$ & $230.533,82$ & $419.992,27$ & $184.581,80$ \\
\hline
\end{tabular}


Tabela 10. Principais resultados obtidos das simulações do segundo cenário logístico para a cadeia como um todo

\begin{tabular}{|c|c|c|c|c|c|c|c|c|c|c|c|c|}
\hline $\begin{array}{l}\text { Simu- } \\
\text { Lação }\end{array}$ & $\begin{array}{l}\text { Núme- } \\
\text { ro de } \\
\text { hastes }\end{array}$ & $\begin{array}{c}\text { Frete } \\
\text { aéreo } \\
\text { (US\$/ } \\
\mathrm{kg})\end{array}$ & $\begin{array}{l}\text { Taxa } \\
\text { câm- } \\
\text { bio } \\
\text { (R\$/ } \\
\text { US\$) }\end{array}$ & $\begin{array}{l}\text { Tipo } \\
\text { de } \\
\text { flor } \\
\end{array}$ & $\begin{array}{l}\text { custo total } \\
\mathrm{s} / \text { insumo } \\
\text { logístico }\end{array}$ & $\begin{array}{l}\text { custo total } \\
\mathrm{c} / \text { insumo } \\
\text { logístico }\end{array}$ & $\begin{array}{c}\text { Receita total } \\
\text { s/ produto } \\
\text { logístico }\end{array}$ & $\begin{array}{l}\text { Receita total } \\
\mathrm{c} / \text { produto } \\
\text { logístico }\end{array}$ & $\begin{array}{l}\text { Lucro total } \\
\mathrm{c} / \text { produto } \\
\text { logístico }\end{array}$ & $\begin{array}{l}\text { Lucro total } \\
\mathrm{c} / \text { insumo } \\
\text { logístico }\end{array}$ & $\begin{array}{l}\text { Lucro total } \\
\text { s/ produto } \\
\text { e.insumo } \\
\text { logísticos } \\
\end{array}$ & $\begin{array}{l}\text { Lucro total } \\
\text { c/ insumo } \\
\text { e.produto } \\
\text { logísticos }\end{array}$ \\
\hline 6 & 75 & 1,25 & 3,81 & gérb2 & $-259.517,90$ & $-497.471,20$ & $1.028 .903,10$ & $956.256,93$ & $696.739,00$ & $531.431,90$ & $769.385,15$ & $458.785,75$ \\
\hline 7 & 75 & 1,40 & 1,50 & gérb2 & $-212.193,10$ & $-372.623,40$ & $405.079,95$ & $6.479,11$ & $164.286,05$ & $32.456,59$ & $192.886,89$ & $3.855,75$ \\
\hline 8 & 75 & 1,40 & 2,41 & gérb2 & $-230.836,20$ & $-422.093,90$ & $650.828,45$ & $604.876,43$ & $374.040,24$ & $228.734,56$ & $419.992,27$ & $182.782,54$ \\
\hline 9 & 75 & 1,40 & 3,81 & gérb2 & $-259.517,90$ & $-500.315,60$ & $1.028 .903,10$ & $6.256,93$ & $696.739,00$ & $28.587,43$ & $769.385,15$ & $455.941,28$ \\
\hline 10 & 75 & 1,50 & 1,50 & gérb2 & $-212.193,10$ & $-373.369,90$ & $405.079,95$ & $6.479,11$ & $164.286,05$ & $31.710,01$ & $192.886,89$ & $3.109,17$ \\
\hline 11 & 75 & 1,50 & 2,41 & gérb2 & $-230.836,20$ & $-423.293,40$ & $650.828,45$ & $4.876,43$ & $374.040,24$ & $227.535,05$ & $419.992,27$ & $181.583,03$ \\
\hline 12 & 75 & 1,50 & 3,81 & gérb2 & $-259.517,90$ & $-502.212,00$ & $1.028 .903,10$ & $956.256,93$ & $696.739,00$ & $526.691,11$ & $769.385,15$ & $454.044,96$ \\
\hline 13 & 80 & 1,10 & 1,50 & gérb2 & $-212.258,90$ & $-365.157,90$ & $405.079,95$ & $376.479,11$ & $164.220,21$ & $39.922,07$ & $192.821,06$ & $11.321,23$ \\
\hline 14 & 80 & 1,10 & 2,41 & gérb2 & $-230.902,00$ & $-412.595,60$ & $650.828,45$ & $604.876,43$ & $373.974,41$ & $238.232,82$ & $419.926,43$ & $192.280,79$ \\
\hline 15 & 80 & 1,10 & 3,81 & gérb2 & $-259.583,80$ & $-487.690,00$ & $1.028 .903,10$ & $956.256,93$ & $696.673,17$ & $541.213,03$ & $769.319,31$ & $468.566,88$ \\
\hline 16 & 80 & 1,25 & 1,50 & gérb2 & $-212.258,90$ & $-366.277,70$ & $405.079,95$ & $376.479,11$ & $164.220,21$ & $38.802,20$ & $192.821,06$ & $10.201,36$ \\
\hline 17 & 80 & 1,25 & 2,41 & gérb2 & $-230.902,00$ & $-414.394,90$ & $650.828,45$ & $604.876,43$ & $373.974,41$ & $236.433,56$ & $419.926,43$ & $190.481,53$ \\
\hline 18 & 80 & 1,25 & 3,81 & gérb2 & $-259.583,80$ & $-490.534,50$ & $1.028 .903,10$ & $956.256,93$ & $696.673,17$ & $538.368,56$ & $769.319,31$ & $465.722,41$ \\
\hline 19 & 80 & 1,40 & 1,50 & gérb2 & $-212.258,90$ & $-367.397,60$ & $405.079,95$ & $376.479,11$ & $164.220,21$ & $37.682,33$ & $192.821,06$ & $9.081,49$ \\
\hline 20 & 80 & 1,40 & 2,41 & gérb2 & $-230.902,00$ & $-416.194,20$ & $650.828,45$ & $604.876,43$ & $373.974,41$ & $234.634,30$ & $419.926,43$ & $188.682,27$ \\
\hline 21 & 80 & 1,40 & 3,81 & gérb2 & $-259.583,80$ & $-493.379,00$ & $1.028 .903,10$ & $956.256,93$ & $696.673,17$ & $535.524,08$ & $769.319,31$ & $462.877,93$ \\
\hline 22 & 80 & 1,50 & 1,50 & gérb2 & $-212.258,90$ & $-368.144,20$ & $405.079,95$ & $376.479,11$ & $164.220,21$ & $36.935,75$ & $192.821,06$ & $8.334,90$ \\
\hline 23 & 80 & 1,50 & 2,41 & gérb2 & -230.902 & $-417.393,70$ & 650.828 & $604.876,43$ & $373.974,41$ & $233.434,79$ & $419.926,43$ & $187.482,77$ \\
\hline 24 & 80 & 1,50 & 3,81 & gérb2 & & $-495.275,30$ & 1.028 .9 & $956.256,93$ & $696.673,17$ & $533.627,76$ & $769.319,31$ & $460.981,62$ \\
\hline 25 & 100 & 1,10 & 1,50 & gérb2 & $2.456,40$ & $-349.480,70$ & $405.079,95$ & $376.479,11$ & $164.022,70$ & $55.599,29$ & $192.623,55$ & $26.998,45$ \\
\hline 26 & 100 & 1,10 & 2,41 & gérb2 & $-231.099,50$ & $-394.896,40$ & $650.828,45$ & $604.876,43$ & $373.776,90$ & $255.932,03$ & $419.728,92$ & $209.980,00$ \\
\hline 27 & 100 & 1,10 & 3,81 & gérb2 & $-259.781,30$ & $-466.880,10$ & $1.028 .903,10$ & $956.256,93$ & $696.475,66$ & $562.022,99$ & $769.121,80$ & $489.376,85$ \\
\hline 28 & 100 & 1,25 & 1,50 & gérb2 & $-212.456,40$ & $-350.600,50$ & $405.079,95$ & $376.479,11$ & $164.022,70$ & $54.479,42$ & $192.623,55$ & $25.878,58$ \\
\hline 29 & 100 & 1,25 & 2,41 & gérb2 & $-231.099,50$ & $-396.695,70$ & $650.828,45$ & $604.876,43$ & $373.776,90$ & $254.132,77$ & $419.728,92$ & $208.180,74$ \\
\hline 30 & 100 & 1,25 & 3,81 & gérb2 & $-259.781,30$ & $-469.724,60$ & $1.028 .903,10$ & $956.256,93$ & $696.475,66$ & $559.178,52$ & $769.121,80$ & $486.532,37$ \\
\hline
\end{tabular}


Tabela 10. Principais resultados obtidos das simulações do segundo cenário logístico para a cadeia como um todo

\begin{tabular}{|c|c|c|c|c|c|c|c|c|c|c|c|c|}
\hline $\begin{array}{l}\text { Simu- } \\
\text { Lação }\end{array}$ & $\begin{array}{l}\text { Núme- } \\
\text { ro de } \\
\text { hastes }\end{array}$ & $\begin{array}{c}\text { Frete } \\
\text { aéreo } \\
\text { (US\$/ } \\
\mathrm{kg})\end{array}$ & $\begin{array}{l}\text { Taxa } \\
\text { câm- } \\
\text { bio } \\
\text { (R\$/ } \\
\text { US\$) }\end{array}$ & $\begin{array}{l}\text { Tipo } \\
\text { de } \\
\text { flor }\end{array}$ & $\begin{array}{c}\text { Custo total } \\
\mathrm{s} / \text { insumo } \\
\text { logístico }\end{array}$ & $\begin{array}{l}\text { Custo total } \\
\mathrm{c} / \text { insumo } \\
\text { logístico }\end{array}$ & $\begin{array}{c}\text { Receita total } \\
\mathrm{s} / \text { produto } \\
\text { logístico }\end{array}$ & $\begin{array}{c}\text { Receita total } \\
\mathrm{c} / \text { produto } \\
\text { logístico }\end{array}$ & $\begin{array}{l}\text { Lucro total } \\
\mathrm{c} / \text { produto } \\
\text { logístico }\end{array}$ & $\begin{array}{c}\text { Lucro total } \\
\mathrm{c} / \text { insumo } \\
\text { logístico }\end{array}$ & $\begin{array}{l}\text { Lucro total } \\
\text { s/ produto } \\
\text { e.insumo } \\
\text { logísticos }\end{array}$ & $\begin{array}{l}\text { Lucro total } \\
\mathrm{c} / \text { insumo } \\
\text { e.produto } \\
\text { logísticos }\end{array}$ \\
\hline 31 & 100 & 1,40 & 1,50 & gérb2 & $-212.456,40$ & $-351.720,40$ & $405.079,95$ & $376.479,11$ & $164.022,70$ & $53.359,55$ & $192.623,55$ & $24.758,70$ \\
\hline 32 & 100 & 1,40 & 2,41 & gérb2 & $-231.099,50$ & $-398.494,90$ & $650.828,45$ & $604.876,43$ & $373.776,90$ & $252.333,51$ & $419.728,92$ & $206.381,48$ \\
\hline 33 & 100 & 1,40 & 3,81 & gérb2 & $-259.781,30$ & $-472.569,00$ & $1.028 .903,10$ & $956.256,93$ & $696.475,66$ & $556.334,04$ & $769.121,80$ & $483.687,90$ \\
\hline 34 & 100 & 1,50 & 1,50 & gérb2 & $-212.456,40$ & $-352.467,00$ & $405.079,95$ & $376.479,11$ & $164.022,70$ & $52.612,97$ & $192.623,55$ & $24.012,12$ \\
\hline 35 & 100 & 1,50 & 2,41 & gérb2 & $-231.099,50$ & $-399.694,50$ & $650.828,45$ & $604.876,43$ & $373.776,90$ & $251.134,00$ & $419.728,92$ & $205.181,97$ \\
\hline 36 & 100 & 1,50 & 3,81 & gérb2 & $-259.781,30$ & $-474.465,30$ & $1.028 .903,10$ & $956.256,93$ & $696.475,66$ & $554.437,73$ & $769.121,80$ & $481.791,58$ \\
\hline
\end{tabular}


Tabela 11. Principais resultados obtidos das simulações do terceiro cenário logístico para a cadeia como um todo

\begin{tabular}{|c|c|c|c|c|c|c|c|c|c|c|c|c|}
\hline $\begin{array}{l}\text { Simu- } \\
\text { Lação }\end{array}$ & $\begin{array}{l}\text { Núme- } \\
\text { ro de } \\
\text { hastes }\end{array}$ & $\begin{array}{c}\text { Frete } \\
\text { aéreo } \\
\text { (US\$/ } \\
\mathrm{kg})\end{array}$ & $\begin{array}{l}\text { Taxa } \\
\text { câm- } \\
\text { bio } \\
\text { (R\$/ } \\
\text { US\$) }\end{array}$ & $\begin{array}{l}\text { Tipo } \\
\text { de } \\
\text { flor }\end{array}$ & $\begin{array}{c}\text { Custo total } \\
\mathrm{s} / \text { insumo } \\
\text { logístico }\end{array}$ & $\begin{array}{c}\text { Custo total } \\
\mathrm{c} / \text { insumo } \\
\text { logístico }\end{array}$ & $\begin{array}{l}\text { Receita total } \\
\mathrm{s} / \text { produto } \\
\text { logístico }\end{array}$ & $\begin{array}{l}\text { Receita total } \\
\mathrm{c} / \text { produto } \\
\text { logístico }\end{array}$ & $\begin{array}{l}\text { Lucro total } \\
\mathrm{c} / \text { produto } \\
\text { logístico }\end{array}$ & $\begin{array}{c}\text { Lucro total } \\
\mathrm{c} / \text { insumo } \\
\text { logístico }\end{array}$ & $\begin{array}{l}\text { Lucro total } \\
\text { s/ produto } \\
\text { e.insumo } \\
\text { logísticos }\end{array}$ & $\begin{array}{l}\text { Lucro total } \\
\mathrm{c} / \text { insumo } \\
\text { e.produto } \\
\text { logísticos }\end{array}$ \\
\hline 1 & 75 & 1,10 & 1,50 & lírio & $-881.260,60$ & $-1.155 .180,00$ & $1.227 .826,60$ & $1.501 .415,80$ & $620.155,17$ & $72.646,72$ & $346.566,02$ & $346.235,87$ \\
\hline 2 & 75 & 1,10 & 2,41 & lírio & $-1.003 .697,00$ & $-1.326 .411,00$ & $1.972 .708,10$ & $2.412 .274,70$ & $1.408 .577,80$ & $646.297,32$ & $969.011,21$ & $1.085 .863,90$ \\
\hline 3 & 75 & 1,10 & 3,81 & lírio & $-1.285 .532,00$ & $-1.685 .428,00$ & $3.118 .679,60$ & $3.813 .596,10$ & $2.528 .064,00$ & $1.433 .251,90$ & $1.833 .147,60$ & $2.128 .168,30$ \\
\hline 4 & 75 & 1,25 & 1,50 & lírio & $-881.260,60$ & $-1.156 .494,00$ & $1.227 .826,60$ & $1.501 .415,80$ & $620.155,17$ & & $346.566,02$ & $344.921,48$ \\
\hline 5 & 75 & 1,25 & 2,41 & lírio & $-1.003 .697,00$ & & $1.972 .708,10$ & $2.412 .274,70$ & $1.408 .577,80$ & & & \\
\hline 6 & 75 & 1,25 & 3,81 & lírio & & & & & $2.528 .064,00$ & & & \\
\hline 7 & 75 & 1,40 & 1,50 & lírio & & & & & & & & \\
\hline 8 & 75 & 1,40 & 2,41 & lírio & & & & & & & & \\
\hline 9 & 75 & 1,40 & 3,81 & lírio & & & & & 2.528 .06 & & $1.833 .147,60$ & \\
\hline 10 & 75 & 1,50 & 1,50 & lírio & & & & & & & & \\
\hline 11 & 75 & 1,50 & 2,41 & lírio & & & & & 1.40 & & 1,21 & 1.08 \\
\hline 12 & 75 & 1,50 & 3,81 & lírio & 2,00 & $1.694 .331,00$ & 3.118 .6 & $3.813 .596,10$ & $2.528 .064,00$ & $1.424 .349,00$ & $1.833 .147,60$ & $2.119 .265,50$ \\
\hline 13 & 80 & 1,10 & 1,50 & lírio & $81.337,90$ & 43,00 & $1.227 .826,60$ & $.501 .415,80$ & $620.077,90$ & $82.883,30$ & $346.488,74$ & $356.472,46$ \\
\hline 14 & 80 & 1,10 & 2,41 & lírio & $-1.003 .774,00$ & $-1.315 .383,00$ & $1.972 .708,10$ & $.412 .274,70$ & $1.408 .500,50$ & $657.324,98$ & $968.933,94$ & $1.096 .891,50$ \\
\hline 15 & 80 & 1,10 & 3,81 & lírio & $-1.285 .609,00$ & $-1.673 .183,00$ & $3.118 .679,60$ & $.813 .596,10$ & $2.527 .986,80$ & $1.445 .496,50$ & $1.833 .070,30$ & $2.140 .413,00$ \\
\hline 16 & 80 & 1,25 & 1,50 & rio & $1.337,90$ & $1.146 .258,00$ & $1.227 .826,60$ & $501.415,80$ & $620.077,90$ & $81.568,91$ & $346.488,74$ & $355.158,06$ \\
\hline 17 & 80 & 1,25 & 2,41 & lírio & $-1.003 .774,00$ & $-1.317 .495,00$ & $1.972 .708,10$ & $2.412 .274,70$ & $1.408 .500,50$ & $655.213,18$ & $968.933,94$ & $1.094 .779,80$ \\
\hline 18 & 80 & 1,25 & 3,81 & lírio & $-1.285 .609,00$ & $-1.676 .522,00$ & $3.118 .679,60$ & $3.813 .596,10$ & $2.527 .986,80$ & $1.442 .158,00$ & $1.833 .070,30$ & $2.137 .074,40$ \\
\hline 19 & 80 & 1,40 & 1,50 & lírio & $-881.337,90$ & $-1.147 .572,00$ & $1.227 .826,60$ & $1.501 .415,80$ & $620.077,90$ & $80.254,52$ & $346.488,74$ & $353.843,67$ \\
\hline 20 & 80 & 1,40 & 2,41 & lírio & $-1.003 .774,00$ & $-1.319 .607,00$ & $1.972 .708,10$ & $2.412 .274,70$ & $1.408 .500,50$ & $653.101,39$ & $968.933,94$ & $1.092 .668,00$ \\
\hline 21 & 80 & 1,40 & 3,81 & lírio & $-1.285 .609,00$ & $-1.679 .860,00$ & $3.118 .679,60$ & $3.813 .596,10$ & $2.527 .986,80$ & $1.438 .819,40$ & $1.833 .070,30$ & $2.133 .735,90$ \\
\hline 22 & 80 & 1,50 & 1,50 & lírio & $-881.337,90$ & $-1.148 .448,00$ & $1.227 .826,60$ & $1.501 .415,80$ & $620.077,90$ & $79.378,25$ & $346.488,74$ & $352.967,41$ \\
\hline 23 & 80 & 1,50 & 2,41 & lírio & $-1.003 .774,00$ & $-1.321 .015,00$ & $1.972 .708,10$ & $2.412 .274,70$ & $1.408 .500,50$ & $651.693,53$ & $968.933,94$ & $1.091 .260,10$ \\
\hline 24 & 80 & 1,50 & 3,81 & lírio & $-1.285 .609,00$ & $-1.682 .086,00$ & $3.118 .679,60$ & $3.813 .596,10$ & $2.527 .986,80$ & $1.436 .593,70$ & $1.833 .070,30$ & $2.1311^{\cdots n n}$ \\
\hline 25 & 100 & 1,10 & 1,50 & lírio & $-881.569,70$ & $-1.114 .234,00$ & $1.227 .826,60$ & $1.501 .415,80$ & & & $346.256,93$ & 387. \\
\hline 26 & 100 & 1,10 & 2,41 & lírio & $-1.004 .006,00$ & $-1.282 .300,00$ & $1.972 .708,10$ & $2.412 .274,70$ & $1.408 .268,70$ & $690.407,95$ & $968.702,12$ & 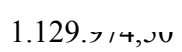 \\
\hline
\end{tabular}

Tabela 11. Principais resultados obtidos das simulações do terceiro cenário logístico para a cadeia como um todo 


\begin{tabular}{|c|c|c|c|c|c|c|c|c|c|c|c|c|}
\hline $\begin{array}{l}\text { Simu- } \\
\text { Lação }\end{array}$ & $\begin{array}{l}\text { Núme- } \\
\text { ro de } \\
\text { hastes }\end{array}$ & $\begin{array}{c}\text { Frete } \\
\text { aéreo } \\
\text { (US\$/ } \\
\mathrm{kg})\end{array}$ & $\begin{array}{l}\text { Taxa } \\
\text { câm- } \\
\text { bio } \\
\text { (R\$/ } \\
\text { US\$) } \\
\end{array}$ & $\begin{array}{l}\text { Tipo } \\
\text { de } \\
\text { flor }\end{array}$ & $\begin{array}{c}\text { Custo total } \\
\mathrm{s} / \text { insumo } \\
\text { logístico }\end{array}$ & $\begin{array}{l}\text { Custo total } \\
\mathrm{c} / \text { insumo } \\
\text { logístico }\end{array}$ & $\begin{array}{l}\text { Receita total } \\
\mathrm{s} / \text { produto } \\
\text { logístico } \\
\end{array}$ & $\begin{array}{l}\text { Receita total } \\
\mathrm{c} / \text { produto } \\
\text { logístico }\end{array}$ & $\begin{array}{c}\text { Lucro total } \\
\mathrm{c} / \text { produto } \\
\text { logístico }\end{array}$ & $\begin{array}{l}\text { Lucro total } \\
\mathrm{c} / \text { insumo } \\
\text { logístico }\end{array}$ & $\begin{array}{l}\text { Lucro total } \\
\text { s/ produto } \\
\text { e.insumo } \\
\text { logísticos } \\
\end{array}$ & $\begin{array}{l}\text { Lucro total } \\
\text { c/ insumo } \\
\text { e.produto } \\
\text { logísticos }\end{array}$ \\
\hline 27 & 100 & 1,10 & 3,81 & lírio & $-1.285 .841,00$ & $-1.636 .449,00$ & $3.118 .679,60$ & $3.813 .596,10$ & $2.527 .755,00$ & $1.482 .230,60$ & $1.832 .838,50$ & $2.177 .147,10$ \\
\hline 28 & 100 & 1,25 & 1,50 & lírio & $-881.569,70$ & $-1.115 .548,00$ & $1.227 .826,60$ & $1.501 .415,80$ & $619.846,08$ & $112.278,67$ & $346.256,93$ & $385.867,82$ \\
\hline 29 & 100 & 1,25 & 2,41 & lírio & & & $1.972 .708,10$ & $2.412 .274,70$ & $1.408 .268,70$ & & & \\
\hline 30 & 100 & 1,25 & 3,81 & lírio & & & & & & & & \\
\hline 31 & 100 & 1,40 & 1,50 & lírio & & & & & & & & \\
\hline 32 & 100 & 1,40 & 2,41 & lírio & & & & & & & & \\
\hline 33 & 100 & 1,40 & 3,81 & lírio & & & $3.118 .679,60$ & $3.813 .596,10$ & $2.527 .755,00$ & $1.475 .553,50$ & $1.832 .838,50$ & $2.170 .469,90$ \\
\hline 34 & 100 & & 1,50 & lírio & & & $1.227 .826,60$ & $1.501 .415,80$ & $619.846,08$ & $110.088,01$ & $346.256,93$ & $383.677,17$ \\
\hline 35 & 100 & & 2,41 & lírio & & $.932,00$ & $1.972 .708,10$ & $2.412 .274,70$ & $1.408 .268,70$ & $684.776,50$ & $968.702,12$ & $1.124 .343,10$ \\
\hline 36 & 100 & 1,50 & 3,81 & lírio & 41,00 & $-1.645 .352,00$ & $3.118 .679,60$ & $3.813 .596,10$ & $2.527 .755,00$ & $1.473 .327,80$ & $1.832 .838,50$ & $2.168 .244,20$ \\
\hline 1 & 75 & 1,10 & 1,50 & gérb1 & 8,60 & $-241.776,60$ & $165.824,34$ & $202.713,59$ & $26.794,99$ & $-75.952,24$ & $-10.094,26$ & $-39.062,99$ \\
\hline 2 & 75 & 1,10 & 2,41 & gérb1 & $-190.014,20$ & $-266.945,70$ & $266.424,44$ & $325.693,17$ & $135.678,95$ & $-521,22$ & $76.410,23$ & $58.747,51$ \\
\hline 3 & 75 & 1,10 & 3,81 & gérb1 & $-211.699,80$ & $-307.780,60$ & $421.193,83$ & $514.892,52$ & $303.192,74$ & $113.413,26$ & $209.494,05$ & $207.111,95$ \\
\hline 4 & 75 & 1,25 & 1,50 & gérb1 & $-175.918,60$ & $-242.117,40$ & $165.824,34$ & $202.713,59$ & $26.794,99$ & $-76.293,02$ & $-10.094,26$ & $-39.403,77$ \\
\hline 5 & 75 & 1,25 & 2,41 & gérb1 & $-190.014,20$ & $-267.493,20$ & $266.424,44$ & $325.693,17$ & $135.678,95$ & $-1.068,74$ & $76.410,23$ & $58.199,99$ \\
\hline 6 & 75 & 1,25 & 3,81 & gérb1 & $-211.699,80$ & $-308.646,10$ & $421.193,83$ & $514.892,52$ & $303.192,74$ & $112.547,68$ & $209.494,05$ & $206.246,38$ \\
\hline 7 & 75 & 1,40 & 1,50 & gérb1 & $-175.918,60$ & $-242.458,10$ & $165.824,34$ & $202.713,59$ & $26.794,99$ & $-76.633,79$ & $-10.094,26$ & $-39.744,54$ \\
\hline 8 & 75 & 1,40 & 2,41 & gérb1 & $-190.014,20$ & $-268.040,70$ & $266.424,44$ & $325.693,17$ & $135.678,95$ & $-1.616,25$ & $76.410,23$ & $57.652,47$ \\
\hline 9 & 75 & 1,40 & 3,81 & gérb1 & $-211.699,80$ & $-309.511,70$ & $421.193,83$ & $514.892,52$ & $303.192,74$ & $111.682,11$ & $209.494,05$ & $205.380,80$ \\
\hline 10 & 75 & 1,50 & 1,50 & gérb1 & $-175.918,60$ & $-242.685,30$ & $165.824,34$ & $202.713,59$ & $26.794,99$ & $-76.860,98$ & $-10.094,26$ & $-39.971,73$ \\
\hline 11 & 75 & 1,50 & 2,41 & gérb1 & $-190.014,20$ & $-268.405,70$ & $266.424,44$ & $325.693,17$ & $135.678,95$ & $-1.981,26$ & $76.410,23$ & $57.287,46$ \\
\hline 12 & 75 & 1,50 & 3,81 & gérb1 & & & & $514.892,52$ & $303.192,74$ & $111.105,06$ & $209.494,05$ & $204.803,75$ \\
\hline 13 & 80 & 1,10 & 1,50 & gérb1 & & & & & $26.774,96$ & $-74.460,21$ & $-10.114,29$ & $-37.570,96$ \\
\hline 14 & 80 & 1,10 & 2,41 & gérb1 & $-190.034,20$ & & & $325.693,17$ & $135.658,92$ & $1.175,91$ & $76.390,19$ & $60 .{ }^{\prime}{ }^{\prime \prime}-1$ \\
\hline 15 & 80 & 1,10 & 3,81 & gérb1 & $-211.719,80$ & $-305.767,90$ & $421.193,83$ & $514.892,52$ & $303.172,71$ & $115.425,93$ & $209.474,02$ & 209. \\
\hline
\end{tabular}

Tabela 11. Principais resultados obtidos das simulações do terceiro cenário logístico para a cadeia como um todo 


\begin{tabular}{|c|c|c|c|c|c|c|c|c|c|c|c|c|}
\hline $\begin{array}{l}\text { Simu- } \\
\text { Lação }\end{array}$ & $\begin{array}{l}\text { Núme- } \\
\text { ro de } \\
\text { hastes }\end{array}$ & $\begin{array}{c}\text { Frete } \\
\text { aéreo } \\
\text { (US\$/ } \\
\mathrm{kg})\end{array}$ & $\begin{array}{l}\text { Taxa } \\
\text { câm- } \\
\text { bio } \\
\text { (R\$/ } \\
\text { US\$) } \\
\end{array}$ & $\begin{array}{l}\text { Tipo } \\
\text { de } \\
\text { flor }\end{array}$ & $\begin{array}{c}\text { Custo total } \\
\mathrm{s} / \text { insumo } \\
\text { logístico }\end{array}$ & $\begin{array}{l}\text { Custo total } \\
\mathrm{c} / \text { insumo } \\
\text { logístico }\end{array}$ & $\begin{array}{c}\text { Receita total } \\
\mathrm{s} / \text { produto } \\
\text { logístico }\end{array}$ & $\begin{array}{l}\text { Receita total } \\
\mathrm{c} / \text { produto } \\
\text { logístico }\end{array}$ & $\begin{array}{l}\text { Lucro total } \\
\mathrm{c} / \text { produto } \\
\text { logístico }\end{array}$ & $\begin{array}{l}\text { Lucro total } \\
\mathrm{c} / \text { insumo } \\
\text { logístico }\end{array}$ & $\begin{array}{c}\text { Lucro total } \\
\text { s/ produto } \\
\text { e.insumo } \\
\text { logísticos } \\
\end{array}$ & $\begin{array}{l}\text { Lucro total } \\
\text { c/ insumo } \\
\text { e.produto } \\
\text { logísticos }\end{array}$ \\
\hline 16 & 80 & 1,25 & 1,50 & gérb1 & $-175.938,60$ & $-240.625,30$ & $165.824,34$ & $202.713,59$ & $26.774,96$ & $-74.800,98$ & $-10.114,29$ & $-37.911,73$ \\
\hline 17 & 80 & 1,25 & 2,41 & gérb1 & $-190.034,20$ & $-265.796,00$ & $266.424,44$ & $5.693,17$ & $135.658,92$ & 628,39 & $76.390,19$ & $59.897,12$ \\
\hline 18 & 80 & 1,25 & 3,81 & gérb1 & $-211.719,80$ & $-306.633,50$ & $421.193,83$ & $4.892,52$ & $303.172,71$ & $114.560,35$ & $209.474,02$ & $208.259,04$ \\
\hline 19 & 80 & 1,40 & 1,50 & gérb1 & $.938,60$ & $-240.966,10$ & $165.824,34$ & $2.713,59$ & $26.774,96$ & $-75.141,76$ & $-10.114,29$ & $-38.252,51$ \\
\hline 20 & 80 & 1,40 & 2,41 & gérb1 & $90.034,20$ & $-266.343,60$ & $266.424,44$ & $5.693,17$ & $135.658,92$ & 80,88 & $76.390,19$ & $59.349,61$ \\
\hline 21 & 80 & 1,40 & 3,81 & gérb1 & $-211.719,80$ & $-307.499,10$ & $421.193,83$ & $4.892,52$ & $303.172,71$ & $113.694,77$ & $209.474,02$ & $207.393,47$ \\
\hline 22 & 80 & 1,50 & 1,50 & gérb1 & $-175.938,60$ & $-241.193,30$ & $165.824,34$ & $2.713,59$ & $26.774,96$ & $-75.368,95$ & $-10.114,29$ & $-38.479,70$ \\
\hline 23 & 80 & 1,50 & 2,41 & gérb1 & $-190.034,20$ & $-266.708,60$ & $266.424,44$ & $325.693,17$ & $135.658,92$ & $-284,13$ & $76.390,19$ & $58.984,59$ \\
\hline 24 & 80 & 1,50 & 3,81 & gérb1 & $-211.719,80$ & $-308.076,10$ & $421.193,83$ & $514.892,52$ & $303.172,71$ & $113.117,72$ & $209.474,02$ & $206.816,41$ \\
\hline 25 & 100 & 1,10 & 1,50 & gérb1 & $-175.998,70$ & $-235.808,40$ & $165.824,34$ & $202.713,59$ & $26.714,85$ & $-69.984,11$ & $-10.174,40$ & $-33.094,86$ \\
\hline 26 & 100 & 1,10 & 2,41 & gérb1 & $-190.094,30$ & $-260.157,10$ & $266.424,44$ & $325.693,17$ & $135.598,82$ & $6.267,30$ & $76.330,09$ & $65.536,03$ \\
\hline 27 & 100 & 1,10 & 3,81 & gérb1 & $-211.779,90$ & $-299.729,90$ & $421.193,83$ & $514.892,52$ & $303.112,61$ & $121.463,92$ & $209.413,92$ & $215.162,62$ \\
\hline 28 & 100 & 1,25 & 1,50 & gérb1 & $-175.998,70$ & $-236.149,20$ & $165.824,34$ & $202.713,59$ & $26.714,85$ & $-70.324,89$ & $-10.174,40$ & $-33.435,64$ \\
\hline 29 & 100 & 1,25 & 2,41 & gérb1 & $-190.094,30$ & $-260.704,70$ & $266.424,44$ & $325.693,17$ & $135.598,82$ & $5.719,79$ & $76.330,09$ & $64.988,51$ \\
\hline 30 & 100 & 1,25 & 3,81 & gérb1 & $-211.779,90$ & $-300.595,50$ & $421.193,83$ & $514.892,52$ & $303.112,61$ & $120.598,35$ & $209.413,92$ & $214.297,04$ \\
\hline 31 & 100 & 1,40 & 1,50 & gérb1 & $-175.998,70$ & $-236.490,00$ & $165.824,34$ & $202.713,59$ & $26.714,85$ & $-70.665,67$ & $-10.174,40$ & $-33.776,42$ \\
\hline 32 & 100 & 1,40 & 2,41 & gérb1 & $-190.094,30$ & $-261.252,20$ & $266.424,44$ & $325.693,17$ & $135.598,82$ & $5.172,27$ & $76.330,09$ & $64.441,00$ \\
\hline 33 & 100 & 1,40 & 3,81 & gérb1 & $-211.779,90$ & $-301.461,10$ & $421.193,83$ & $514.892,52$ & $303.112,61$ & $119.732,77$ & $209.413,92$ & $213.431,46$ \\
\hline 34 & 100 & 1,50 & 1,50 & gérl & $-175.998,70$ & $-236.717,20$ & $165.824,34$ & $202.713,59$ & $26.714,85$ & $-70.892,85$ & $-10.174,40$ & $-34.003,60$ \\
\hline 35 & 100 & 1,50 & 2,41 & gérb1 & $-190.094,30$ & $-261.617,20$ & $266.424,44$ & $325.693,17$ & $135.598,82$ & $4.807,26$ & $76.330,09$ & $64.075,98$ \\
\hline 36 & 100 & 1,50 & 3,81 & gérb1 & $-211.779,90$ & $-302.038,10$ & $421.193,83$ & $514.892,52$ & $303.112,61$ & $119.155,72$ & $209.413,92$ & $212.854,41$ \\
\hline 1 & 75 & 1,10 & 1,50 & gérb2 & $-227.841,30$ & $-386.948,30$ & $430.180,33$ & $526.143,82$ & $298.302,50$ & $43.232,03$ & $202.339,02$ & $139.195,52$ \\
\hline 2 & 75 & 1,10 & 2,41 & gérb2 & $-255.996,90$ & $-443.909,30$ & $691.156,40$ & $845.337,73$ & $589.340,83$ & $247.247,14$ & $435.159,51$ & $401.428,47$ \\
\hline 3 & 75 & 1,10 & 3,81 & gérb2 & $-299.313,20$ & $-533.654,80$ & $1.092 .658,00$ & $1.336 .405,30$ & $1.037 .092,10$ & $559.003,29$ & $793.344,87$ & $802 .^{7 \sim n}-1$ \\
\hline 4 & 75 & 1,25 & 1,50 & gérb2 & $-227.841,30$ & $-388.101,80$ & $430.180,33$ & $526.143,82$ & $298.302,50$ & $42.078,57$ & $202.339,02$ & 138. \\
\hline
\end{tabular}

Tabela 11. Principais resultados obtidos das simulações do terceiro cenário logístico para a cadeia como um todo 


\begin{tabular}{|c|c|c|c|c|c|c|c|c|c|c|c|c|}
\hline $\begin{array}{l}\text { Simu- } \\
\text { Lação }\end{array}$ & $\begin{array}{l}\text { Núme- } \\
\text { ro de } \\
\text { hastes }\end{array}$ & $\begin{array}{c}\text { Frete } \\
\text { aéreo } \\
\text { (US\$/ } \\
\mathrm{kg})\end{array}$ & $\begin{array}{l}\text { Taxa } \\
\text { câm- } \\
\text { bio } \\
\text { (R\$/ } \\
\text { US\$) } \\
\end{array}$ & $\begin{array}{l}\text { Tipo } \\
\text { de } \\
\text { flor }\end{array}$ & $\begin{array}{c}\text { Custo total } \\
\mathrm{s} / \text { insumo } \\
\text { logístico }\end{array}$ & $\begin{array}{l}\text { Custo total } \\
\mathrm{c} / \text { insumo } \\
\text { logístico }\end{array}$ & $\begin{array}{c}\text { Receita total } \\
\mathrm{s} / \text { produto } \\
\text { logístico }\end{array}$ & $\begin{array}{l}\text { Receita total } \\
\mathrm{c} / \text { produto } \\
\text { logístico }\end{array}$ & $\begin{array}{l}\text { Lucro total } \\
\mathrm{c} / \text { produto } \\
\text { logístico }\end{array}$ & $\begin{array}{l}\text { Lucro total } \\
\mathrm{c} / \text { insumo } \\
\text { logístico }\end{array}$ & $\begin{array}{c}\text { Lucro total } \\
\text { s/ produto } \\
\text { e.insumo } \\
\text { logísticos } \\
\end{array}$ & $\begin{array}{l}\text { Lucro total } \\
\text { c/ insumo } \\
\text { e.produto } \\
\text { logísticos }\end{array}$ \\
\hline 5 & 75 & 1,25 & 2,41 & gérb2 & $-255.996,90$ & $-445.762,50$ & $691.156,40$ & $845.337,73$ & $589.340,83$ & $245.393,90$ & $435.159,51$ & $399.575,23$ \\
\hline 6 & 75 & 1,25 & 3,81 & gérb2 & $-299.313,20$ & $-536.584,60$ & $1.092 .658,00$ & $1.336 .405,30$ & $1.037 .092,10$ & $556.073,49$ & $793.344,87$ & $799.820,73$ \\
\hline 7 & 75 & 1,40 & 1,50 & gérb2 & $-227.841,30$ & $-389.255,20$ & $430.180,33$ & $526.143,82$ & $298.302,50$ & $40.925,10$ & $202.339,02$ & $136.888,58$ \\
\hline 8 & 75 & 1,40 & 2,41 & gérb2 & $5.996,90$ & $17.615,70$ & $691.156,40$ & $845.337,73$ & $589.340,83$ & $43.540,66$ & $435.159,51$ & $397.721,99$ \\
\hline 9 & 75 & 1,40 & 3,81 & érb2 & $-299.313,20$ & $-539.514,40$ & $1.092 .658,00$ & $1.336 .405,30$ & $1.037 .092,10$ & $33.143,68$ & $793.344,87$ & $796.890,92$ \\
\hline 10 & 75 & 1,50 & 1,50 & gérb2 & $-227.841,30$ & $-390.024,20$ & $430.180,33$ & $526.143,82$ & $298.302,50$ & $40.156,12$ & $202.339,02$ & $136.119,60$ \\
\hline 11 & 75 & 1,50 & 2,41 & gérb2 & $-255.996,90$ & $-448.851,20$ & $691.156,40$ & $845.337,73$ & $589.340,83$ & $242.305,17$ & $435.159,51$ & $396.486,50$ \\
\hline 12 & 75 & 1,50 & 3,81 & gérb2 & $-299.313,20$ & $-541.467,60$ & $1.092 .658,00$ & $1.336 .405,30$ & $1.037 .092,10$ & $551.190,47$ & $793.344,87$ & $94.937,72$ \\
\hline 13 & 80 & 1,10 & 1,50 & gérb2 & $-227.909,10$ & $-381.565,80$ & $430.180,33$ & $526.143,82$ & $298.234,69$ & $48.614,54$ & $202.271,21$ & $144.578,03$ \\
\hline 14 & 80 & 1,10 & 2,41 & gérb2 & -256 & $-437.832,50$ & $691.156,40$ & $15.337,73$ & $589.273,02$ & $253.323,87$ & $35.091,70$ & $07.505,20$ \\
\hline 15 & 80 & 1,10 & 3,81 & gérb2 & $-299.381,00$ & $-526.510,00$ & $1.092 .658,00$ & $1.336 .405,30$ & $1.037 .024,30$ & $566.148,05$ & $793.277,06$ & $809.895,29$ \\
\hline 16 & 80 & 1,25 & 1,50 & gérb2 & $-227.909,10$ & $-382.719,30$ & $430.180,33$ & $526.143,82$ & $298.234,69$ & $47.461,08$ & $202.271,21$ & $143.424,56$ \\
\hline 17 & 80 & 1,25 & 2,41 & gérb2 & $-256.064,70$ & $-439.685,80$ & $691.156,40$ & $845.337,73$ & $589.273,02$ & $251.470,63$ & $435.091,70$ & $405.651,96$ \\
\hline 18 & 80 & 1,25 & 3,81 & gérb2 & $-299.381,00$ & $-529.439,80$ & $1.092 .658,00$ & $1.336 .405,30$ & $1.037 .024,30$ & $563.218,24$ & $793.277,06$ & $806.965,49$ \\
\hline 19 & 80 & 1,40 & 1,50 & gérb2 & $-227.909,10$ & $-383.872,70$ & $430.180,33$ & $526.143,82$ & 298.234,69 & $46.307,61$ & $202.271,21$ & $142.271,09$ \\
\hline 20 & 80 & 1,40 & 2,41 & gérb2 & $-256.064,70$ & $-441.539,00$ & $691.156,40$ & $845.337,73$ & $589.273,02$ & $249.617,39$ & $435.091,70$ & $403.798,72$ \\
\hline 21 & 80 & 1,40 & 3,81 & gérb2 & $-299.381,00$ & $-532.369,60$ & $1.092 .658,00$ & $1.336 .405,30$ & $1.037 .024,30$ & $560.288,43$ & $793.277,06$ & $804.035,68$ \\
\hline 22 & 80 & 1,50 & 1,50 & gérb2 & $-227.909,10$ & $-384.641,70$ & $430.180,33$ & $526.143,82$ & $298.234,69$ & $45.538,63$ & $202.271,21$ & $141.502,11$ \\
\hline 23 & 80 & 1,50 & 2,41 & gérb2 & $-256.064,70$ & $-442.774,50$ & $691.156,40$ & $845.337,73$ & $589.273,02$ & $248.381,90$ & $435.091,70$ & $402.563,23$ \\
\hline 24 & 80 & 1,50 & 3,81 & gérb2 & $-299.381,00$ & $-534.322,80$ & $1.092 .658,00$ & $1.336 .405,30$ & $1.037 .024,30$ & $558.335,23$ & $793.277,06$ & $802.082,47$ \\
\hline 25 & 100 & 1,10 & 1,50 & gérb2 & $-228.112,60$ & $-365.418,30$ & $430.180,33$ & $526.143,82$ & $298.031,25$ & $64.762,08$ & $202.067,77$ & $160.725,56$ \\
\hline 26 & 100 & 1,10 & 2,41 & & $-256.268,10$ & $-419.602,40$ & $691.156,40$ & $845.337,73$ & $589.069,59$ & $271.554,05$ & $434.888,26$ & $425.735,38$ \\
\hline 27 & 100 & 1,10 & 3,81 & gérb2 & $-299.584,40$ & $-505.075,70$ & $1.092 .658,00$ & $1.336 .405,30$ & $1.036 .820,90$ & $587.582,31$ & $793.073,63$ & $831.329,56$ \\
\hline 28 & 100 & 1,25 & 1,50 & gérb2 & $-228.112,60$ & $-366.571,70$ & $430.180,33$ & $526.143,82$ & $298.031,25$ & $63.608,61$ & $202.067,77$ & $159.5^{-\cdots}$ \\
\hline 29 & 100 & 1,25 & 2,41 & gérb2 & $-256.268,10$ & $-421.455,60$ & $691.156,40$ & $845.337,73$ & $589.069,59$ & $269.700,81$ & $434.888,26$ & 423.8 \\
\hline
\end{tabular}

Tabela 11. Principais resultados obtidos das simulações do terceiro cenário logístico para a cadeia como um todo 


\begin{tabular}{|c|c|c|c|c|c|c|c|c|c|c|c|c|}
\hline $\begin{array}{l}\text { Simu- } \\
\text { Lação }\end{array}$ & $\begin{array}{l}\text { Núme- } \\
\text { ro de } \\
\text { hastes }\end{array}$ & $\begin{array}{c}\text { Frete } \\
\text { aéreo } \\
\text { (US\$/ } \\
\mathrm{kg})\end{array}$ & $\begin{array}{l}\text { Taxa } \\
\text { câm- } \\
\text { bio } \\
\text { (R\$/ } \\
\text { US\$) } \\
\end{array}$ & $\begin{array}{l}\text { Tipo } \\
\text { de } \\
\text { flor }\end{array}$ & $\begin{array}{c}\text { Custo total } \\
\mathrm{s} / \text { insumo } \\
\text { logístico }\end{array}$ & $\begin{array}{l}\text { Custo total } \\
\mathrm{c} / \text { insumo } \\
\text { logístico }\end{array}$ & $\begin{array}{c}\text { Receita total } \\
\mathrm{s} / \text { produto } \\
\text { logístico }\end{array}$ & $\begin{array}{l}\text { Receita total } \\
\mathrm{c} / \text { produto } \\
\text { logístico }\end{array}$ & $\begin{array}{c}\text { Lucro total } \\
\mathrm{c} / \text { produto } \\
\text { logístico }\end{array}$ & $\begin{array}{l}\text { Lucro total } \\
\mathrm{c} / \text { insumo } \\
\text { logístico }\end{array}$ & $\begin{array}{l}\text { Lucro total } \\
\mathrm{s} / \text { produto } \\
\text { e.insumo } \\
\text { logísticos }\end{array}$ & $\begin{array}{l}\text { Lucro total } \\
\text { c/ insumo } \\
\text { e.produto } \\
\text { logísticos }\end{array}$ \\
\hline 30 & 100 & 1,25 & 3,81 & gérb2 & $\begin{array}{l}-299.584,40 \\
\end{array}$ & $-508.005,50$ & $1.092 .658,00$ & $1.336 .405,30$ & $1.036 .820,90$ & $584.652,50$ & $793.073,63$ & $828.399,75$ \\
\hline 31 & 100 & 1,40 & 1,50 & gérb2 & $-228.112,60$ & $-367.725,20$ & $430.180,33$ & $526.143,82$ & $298.031,25$ & $62.455,14$ & $202.067,77$ & $158.418,62$ \\
\hline 32 & 100 & 1,40 & 2,41 & gérb2 & $-256.268,10$ & $-423.308,80$ & $691.156,40$ & $845.337,73$ & $589.069,59$ & $267.847,58$ & $434.888,26$ & $422.028,90$ \\
\hline 33 & 100 & 1,40 & 3,81 & gérb2 & $-299.584,40$ & $-510.935,40$ & $1.092 .658,00$ & $1.336 .405,30$ & $1.036 .820,90$ & $581.722,69$ & $793.073,63$ & $825.469,94$ \\
\hline 34 & 100 & 1,50 & 1,50 & gérb2 & $-228.112,60$ & $-368.494,20$ & $430.180,33$ & $526.143,82$ & $298.031,25$ & $61.686,16$ & $202.067,77$ & $157.649,65$ \\
\hline 35 & 100 &, 50 & 2,41 & & & & & & & & $434.888,26$ & $20.793,41$ \\
\hline 36 & 100 & 1,50 & 3,81 & gérb2 & $-299.584,40$ & $-512.888,60$ & $1.092 .658,00$ & $1.336 .405,30$ & $1.036 .820,90$ & $579.769,49$ & $793.073,63$ & $823.516,73$ \\
\hline
\end{tabular}


Tabela 12. Principais resultados obtidos das simulações do quarto cenário logístico para a cadeia como um todo

\begin{tabular}{|c|c|c|c|c|c|c|c|c|c|c|c|c|}
\hline $\begin{array}{l}\text { Simu- } \\
\text { Lação }\end{array}$ & $\begin{array}{l}\text { Núme- } \\
\text { ro de } \\
\text { hastes }\end{array}$ & $\begin{array}{c}\text { Frete } \\
\text { aéreo } \\
\text { (US\$/ } \\
\mathrm{kg} \text { ) }\end{array}$ & $\begin{array}{c}\text { Taxa } \\
\text { câm- } \\
\text { bio } \\
\text { (R\$/ } \\
\text { US\$) } \\
\end{array}$ & $\begin{array}{l}\text { Tipo } \\
\text { de } \\
\text { flor }\end{array}$ & $\begin{array}{c}\text { Custo total } \\
\mathrm{s} / \text { insumo } \\
\text { logístico }\end{array}$ & $\begin{array}{l}\text { Custo total } \\
\mathrm{c} / \text { insumo } \\
\text { logístico }\end{array}$ & $\begin{array}{c}\text { Receita total } \\
\mathrm{s} / \text { produto } \\
\text { logístico }\end{array}$ & $\begin{array}{c}\text { Receita total } \\
\mathrm{c} / \text { produto } \\
\text { logístico }\end{array}$ & $\begin{array}{c}\text { Lucro total } \\
\mathrm{c} / \text { produto } \\
\text { logístico }\end{array}$ & $\begin{array}{l}\text { Lucro total } \\
\mathrm{c} / \text { insumo } \\
\text { logístico }\end{array}$ & $\begin{array}{l}\text { Lucro total } \\
\text { s/ produto } \\
\text { e.insumo } \\
\text { logísticos }\end{array}$ & $\begin{array}{l}\text { Lucro total } \\
\text { c/ insumo } \\
\text { e.produto } \\
\text { logísticos }\end{array}$ \\
\hline 1 & 75 & 1,10 & 1,50 & lírio & $-844.758,40$ & $-1.108 .233,00$ & $1.091 .631,10$ & $1.014 .583,70$ & $169.825,26$ & $-16.602,28$ & $246.872,68$ & $-93.649,70$ \\
\hline 2 & 75 & 1,10 & 2,41 & lírio & $-938.119,00$ & $1.250 .532,00$ & $1.753 .887,30$ & $630.097,80$ & $691.978,77$ & $503.354,91$ & $815.768,29$ & $379.565,39$ \\
\hline 3 & 75 & 1,10 & 3,81 & lírio & $-1.175 .222,00$ & $-1.565 .039,00$ & $2.772 .743,00$ & $2.577 .042,60$ & $1.401 .820,30$ & $1.207 .704,20$ & $1.597 .520,70$ & $1.012 .003,80$ \\
\hline 4 & 75 & 1,25 & 1,50 & lírio & $-844.758,40$ & $-1.109 .438,00$ & $1.091 .631,10$ & $1.014 .583,70$ & $169.825,26$ & $-17.807,15$ & $246.872,68$ & $-94.854,56$ \\
\hline 5 & 75 & 1,25 & 2,41 & lírio & $-938.119,00$ & $-1.252 .468,00$ & $1.753 .887,30$ & $1.630 .097,80$ & $691.978,77$ & $501.419,10$ & $815.768,29$ & $377.629,58$ \\
\hline 6 & 75 & 1,25 & 3,81 & lírio & $-1.175 .222,00$ & $-1.568 .099,00$ & $2.772 .743,00$ & $2.577 .042,60$ & $1.401 .820,30$ & $1.204 .643,90$ & $1.597 .520,70$ & $1.008 .943,40$ \\
\hline 7 & 75 & 1,40 & 1,50 & lírio & $-844.758,40$ & $-1.110 .643,00$ & $1.091 .631,10$ & $1.014 .583,70$ & $169.825,26$ & $-19.012,01$ & $246.872,68$ & $-96.059,43$ \\
\hline 8 & 75 & 1,40 & 2,41 & lírio & $-938.119,00$ & $-1.254 .404,00$ & $1.753 .887,30$ & $1.630 .097,80$ & $691.978,77$ & $499.483,29$ & $815.768,29$ & $375.693,77$ \\
\hline 9 & 75 & 1,40 & 3,81 & lírio & $-1.175 .222,00$ & -1.571 .16 & $2.772 .743,00$ & $2.577 .042,60$ & $1.401 .820,30$ & $1.201 .583,50$ & $1.597 .520,70$ & $1.005 .883,10$ \\
\hline 10 & 75 & 1,50 & 1,50 & lírio & $-844.758,40$ & $-1.111 .446,00$ & 1.091 .63 & $1.014 .583,70$ & $169.825,26$ & $-19.815,25$ & $246.872,68$ & $-96.862,67$ \\
\hline 11 & 75 & 1,50 & 2,41 & lírio & $-938.119,00$ & $-1.255 .695,00$ & $1.753 .887,30$ & $1.630 .097,80$ & $691.978,77$ & $498.192,75$ & $815.768,29$ & $374.403,23$ \\
\hline 12 & 75 & 1,50 & 3,81 & lírio & $-1.175 .222,00$ & $-1.573 .200,00$ & $2.772 .743,00$ & $2.577 .042,60$ & $1.401 .820,30$ & $1.199 .543,30$ & $1.597 .520,70$ & $1.003 .842,80$ \\
\hline 13 & 80 & 1,10 & 1,50 & lírio & $-844.121,70$ & $-1.098 .049,00$ & $1.091 .631,10$ & $1.014 .583,70$ & $170.462,04$ & $-6.418,32$ & $247.509,46$ & $-83.465,74$ \\
\hline 14 & 80 & 1,10 & 2,41 & lírio & & & & $1.630 .097,80$ & & & & $390.480,20$ \\
\hline 15 & 80 & 1,10 & 3,81 & lírio & & & 2.77 & $2.577 .042,60$ & 1.402 & $1.219 .743,40$ & $1.598 .157,50$ & $1.024 .043,00$ \\
\hline 16 & 80 & 1,25 & 1,50 & lírio & ,70 & $-1.099 .254,00$ & $1.091 .631,10$ & $1.014 .583,70$ & $170.462,04$ & $-7.623,18$ & $247.509,46$ & $-84.670,60$ \\
\hline 17 & 80 & 1,25 & 2,41 & lírio & $-937.482,30$ & $-1.241 .553,00$ & $1.753 .887,30$ & $1.630 .097,80$ & $692.615,55$ & $512.333,91$ & $816.405,07$ & $388.544,39$ \\
\hline 18 & 80 & 1,25 & 3,81 & lírio & $-1.174 .586,00$ & $-1.556 .060,00$ & $2.772 .743,00$ & $2.577 .042,60$ & $1.402 .457,00$ & $1.216 .683,10$ & $1.598 .157,50$ & $1.020 .982,60$ \\
\hline 19 & 80 & 1,40 & 1,50 & lírio & $-844.121,70$ & $-1.100 .459,00$ & $1.091 .631,10$ & $1.014 .583,70$ & $170.462,04$ & $-8.828,04$ & $247.509,46$ & $-85.875,46$ \\
\hline 20 & 80 & 1,40 & 2,41 & lírio & $-937.482,30$ & $-1.243 .489,00$ & $1.753 .887,30$ & $1.630 .097,80$ & $692.615,55$ & $510.398,10$ & $816.405,07$ & $386.608,58$ \\
\hline 21 & 80 & 1,40 & 3,81 & lírio & $-1.174 .586,00$ & $-1.559 .120,00$ & $2.772 .743,00$ & $2.577 .042,60$ & $1.402 .457,00$ & $1.213 .622,70$ & $1.598 .157,50$ & $1.017 .922,30$ \\
\hline 22 & 80 & 1,50 & 1,50 & lírio & $-844.121,70$ & $-1.101 .262,00$ & $1.091 .631,10$ & $1.014 .583,70$ & $170.462,04$ & $-9.631,28$ & $247.509,46$ & $-86.678,70$ \\
\hline 23 & 80 & 1,50 & 2,41 & lírio & $-937.482,30$ & $-1.244 .780,00$ & $1.753 .887,30$ & $1.630 .097,80$ & $692.615,55$ & $509.107,56$ & $816.405,07$ & $385.318,04$ \\
\hline 24 & 80 & 1,50 & 3,81 & lírio & $-1.174 .586,00$ & $-1.561 .161,00$ & $2.772 .743,00$ & $2.577 .042,60$ & $1.402 .457,00$ & $1.211 .582,50$ & $1.598 .157,50$ & $1.015 .882,00$ \\
\hline 25 & 100 & 1,10 & 1,50 & lírio & $-842.211,30$ & $-1.067 .498,00$ & $1.091 .631,10$ & $1.014 .583,70$ & $172.372,37$ & $24.133,57$ & $249.419,79$ & $-52.913,85$ \\
\hline
\end{tabular}


Tabela 12. Principais resultados obtidos das simulações do quarto cenário logístico para a cadeia como um todo

\begin{tabular}{|c|c|c|c|c|c|c|c|c|c|c|c|c|}
\hline $\begin{array}{l}\text { Simu- } \\
\text { Lação }\end{array}$ & $\begin{array}{l}\text { Núme- } \\
\text { ro de } \\
\text { hastes }\end{array}$ & $\begin{array}{c}\text { Frete } \\
\text { aéreo } \\
\text { (US\$/ } \\
\mathrm{kg})\end{array}$ & $\begin{array}{l}\text { Taxa } \\
\text { câm- } \\
\text { bio } \\
\text { (R\$/ } \\
\text { US\$) } \\
\end{array}$ & $\begin{array}{l}\text { Tipo } \\
\text { de } \\
\text { flor }\end{array}$ & $\begin{array}{l}\text { Custo total } \\
\mathrm{s} / \text { insumo } \\
\text { logístico }\end{array}$ & $\begin{array}{l}\text { Custo total } \\
\mathrm{c} / \text { insumo } \\
\text { logístico }\end{array}$ & $\begin{array}{c}\text { Receita total } \\
\mathrm{s} / \text { produto } \\
\text { logístico }\end{array}$ & $\begin{array}{c}\text { Receita total } \\
\mathrm{c} / \text { produto } \\
\text { logístico }\end{array}$ & $\begin{array}{l}\text { Lucro total } \\
\mathrm{c} / \text { produto } \\
\text { logístico }\end{array}$ & $\begin{array}{l}\text { Lucro total } \\
\mathrm{c} / \text { insumo } \\
\text { logístico }\end{array}$ & $\begin{array}{l}\text { Lucro total } \\
\text { s/ produto } \\
\text { e.insumo } \\
\text { logísticos }\end{array}$ & $\begin{array}{l}\text { Lucro total } \\
\text { c/ insumo } \\
\text { e.produto } \\
\text { logísticos }\end{array}$ \\
\hline 26 & 100 & 1,10 & 2,41 & lírio & $-935.571,90$ & $-1.206 .873,00$ & $1.753 .887,30$ & $1.630 .097,80$ & $694.525,88$ & $547.014,15$ & $818.315,40$ & $423.224,63$ \\
\hline 27 & 100 & 1,10 & 3,81 & lírio & $-1.172 .675,00$ & $-1.516 .882,00$ & $2.772 .743,00$ & $2.577 .042,60$ & $1.404 .367,40$ & $1.255 .861,00$ & $1.600 .067,80$ & $1.060 .160,50$ \\
\hline 28 & 100 & 1,25 & 1,50 & lírio & $-842.211,30$ & $-1.068 .702,00$ & $1.091 .631,10$ & $1.014 .583,70$ & $172.372,37$ & $22.928,71$ & $249.419,79$ & $-54.118,71$ \\
\hline 29 & 100 & 1,25 & 2,41 & lírio & $-935.571,90$ & $-1.208 .809,00$ & $1.753 .887,30$ & $1.630 .097,80$ & $694.525,88$ & $545.078,34$ & $818.315,40$ & $421.288,82$ \\
\hline 30 & 100 & 1,25 & 3,81 & lírio & $-1.172 .675,00$ & $-1.519 .942,00$ & $2.772 .743,00$ & $2.577 .042,60$ & $1.404 .367,40$ & $1.252 .800,60$ & $1.600 .067,80$ & $1.057 .100,20$ \\
\hline 31 & 100 & 1,40 & 1,50 & lírio & $-842.211,30$ & $-1.069 .907,00$ & $1.091 .631,10$ & $1.014 .583,70$ & $172.372,37$ & $21.723,85$ & $249.419,79$ & $-55.323,57$ \\
\hline 32 & 100 & 1,40 & 2,41 & lírio & $-935.571,90$ & $-1.210 .745,00$ & $1.753 .887,30$ & $1.630 .097,80$ & $694.525,88$ & $543.142,52$ & $818.315,40$ & $419.353,01$ \\
\hline 33 & 100 & 1,40 & 3,81 & lírio & $-1.172 .675,00$ & $-1.523 .003,00$ & $2.772 .743,00$ & $2.577 .042,60$ & $1.404 .367,40$ & $1.249 .740,30$ & $1.600 .067,80$ & $1.054 .039,80$ \\
\hline 34 & 100 & 1,50 & 1,50 & lírio & $-842.211,30$ & $-1.070 .711,00$ & $1.091 .631,10$ & $1.014 .583,70$ & $172.372,37$ & $20.920,61$ & $249.419,79$ & $-56.126,81$ \\
\hline 35 & 100 & 1,50 & 2,41 & lírio & $-935.571,90$ & $-1.212 .035,00$ & $1.753 .887,30$ & $1.630 .097,80$ & $694.525,88$ & $541.851,98$ & $818.315,40$ & $418.062,47$ \\
\hline 36 & 100 & 1,50 & 3,81 & lírio & $-1.172 .675,00$ & $-1.525 .043,00$ & $2.772 .743,00$ & $2.577 .042,60$ & $1.404 .367,40$ & $1.247 .700,00$ & $1.600 .067,80$ & $1.051 .999,60$ \\
\hline 1 & 75 & 1,10 & 1,50 & gérb1 & $-172.413,60$ & $-236.614,20$ & $147.430,43$ & $137.042,00$ & $-35.371,60$ & $-89.183,73$ & $-24.983,17$ & $-99.572,16$ \\
\hline 2 & 75 & 1,10 & 2,41 & gérb1 & $82.585,90$ & $-257.700,30$ & $236.871,56$ & $220.180,82$ & $37.594,95$ & $-20.828,77$ & $54.285,69$ & $-37.519,51$ \\
\hline 3 & 75 & 1,10 & 3,81 & gérb1 & & & & & & & & \\
\hline 4 & 75 & 1,25 & 1,50 & gérb1 & & & & & & $-89.496,11$ & $-24.983,17$ & $-99.884,54$ \\
\hline 5 & 75 & 1,25 & 2,41 & & & & $236.871,56$ & 220.1 & $37.594,95$ & $-21.330,66$ & $54.285,69$ & $-38.021,40$ \\
\hline 6 & 75 & 1,25 & 3,81 & & & & 73,30 & 348.08 & $149.851,17$ & $81.426,03$ & $176.237,79$ & $55.039,42$ \\
\hline 7 & 75 & 1,40 & 1,50 & gérb1 & -172.413 & $-237.238,90$ & $147.430,43$ & $137.042,00$ & $-35.371,60$ & $-89.808,49$ & $-24.983,17$ & $-100.196,90$ \\
\hline 8 & 75 & 1,40 & 2,41 & gérb1 & $-182.585,90$ & $-258.704,10$ & $236.871,56$ & $220.180,82$ & $37.594,95$ & $-21.832,55$ & $54.285,69$ & $-38.523,29$ \\
\hline 9 & 75 & 1,40 & 3,81 & gérb1 & $-198.235,50$ & $-293.840,70$ & $374.473,30$ & $348.086,69$ & $149.851,17$ & $80.632,59$ & $176.237,79$ & $54.245,97$ \\
\hline 10 & 75 & 1,50 & 1,50 & gérb1 & $-172.413,60$ & $-237.447,20$ & $147.430,43$ & $137.042,00$ & $-35.371,60$ & $-90.016,74$ & $-24.983,17$ & $-100.405,20$ \\
\hline 11 & 75 & 1,50 & 2,41 & gérb1 & $-182.585,90$ & $-259.038,70$ & $236.871,56$ & $220.180,82$ & $37.594,95$ & $-22.167,14$ & $54.285,69$ & $-38.857,89$ \\
\hline 12 & 75 & 1,50 & 3,81 & gérb1 & $-198.235,50$ & $-294.369,70$ & $374.473,30$ & $348.086,69$ & $149.851,17$ & $80.103,62$ & $176.237,79$ & $53.717,01$ \\
\hline 13 & 80 & 1,10 & 1,50 & gérb1 & $-172.248,50$ & $-235.049,70$ & $147.430,43$ & $137.042,00$ & $-35.206,51$ & $-87.619,27$ & $-24.818,08$ & $-98.007,70$ \\
\hline 14 & 80 & 1,10 & 2,41 & gérb1 & $-182.420,80$ & $-255.946,40$ & $236.871,56$ & $220.180,82$ & $37.760,04$ & $-19.074,82$ & $54.450,78$ & $-35.765,57$ \\
\hline
\end{tabular}


Tabela 12. Principais resultados obtidos das simulações do quarto cenário logístico para a cadeia como um todo

\begin{tabular}{|c|c|c|c|c|c|c|c|c|c|c|c|c|}
\hline $\begin{array}{l}\text { Simu- } \\
\text { Lação }\end{array}$ & $\begin{array}{l}\text { Núme- } \\
\text { ro de } \\
\text { hastes }\end{array}$ & $\begin{array}{c}\text { Frete } \\
\text { aéreo } \\
\text { (US\$/ } \\
\mathrm{kg})\end{array}$ & $\begin{array}{l}\text { Taxa } \\
\text { câm- } \\
\text { bio } \\
\text { (R\$/ } \\
\text { US\$) }\end{array}$ & $\begin{array}{l}\text { Tipo } \\
\text { de } \\
\text { flor } \\
\end{array}$ & $\begin{array}{c}\text { Custo total } \\
\mathrm{s} / \text { insumo } \\
\text { logístico }\end{array}$ & $\begin{array}{l}\text { Custo total } \\
\mathrm{c} / \text { insumo } \\
\text { logístico }\end{array}$ & $\begin{array}{c}\text { Receita total } \\
\mathrm{s} / \text { produto } \\
\text { logístico }\end{array}$ & $\begin{array}{l}\text { Receita total } \\
\mathrm{c} / \text { produto } \\
\text { logístico }\end{array}$ & $\begin{array}{l}\text { Lucro total } \\
\mathrm{c} / \text { produto } \\
\text { logístico }\end{array}$ & $\begin{array}{l}\text { Lucro total } \\
\mathrm{c} / \text { insumo } \\
\text { logístico }\end{array}$ & $\begin{array}{l}\text { Lucro total } \\
\text { s/ produto } \\
\text { e.insumo } \\
\text { logísticos } \\
\end{array}$ & $\begin{array}{l}\text { Lucro total } \\
\text { c/ insumo } \\
\text { e.produto } \\
\text { logísticos }\end{array}$ \\
\hline 15 & 80 & 1,10 & 3,81 & gérb1 & $-198.070,40$ & $-290.208,40$ & $374.473,30$ & $348.086,69$ & $150.016,27$ & $84.264,93$ & $176.402,88$ & $57.878,32$ \\
\hline 16 & 80 & 1,25 & 1,50 & gérb1 & $-172.248,50$ & $-235.362,10$ & $147.430,43$ & $137.042,00$ & $-35.206,51$ & $-87.931,65$ & $-24.818,08$ & $-98.320,08$ \\
\hline 17 & 80 & 1,25 & 2,41 & gérb1 & $-182.420,80$ & $-256.448,30$ & $236.871,56$ & $220.180,82$ & $37.760,04$ & $-19.576,71$ & $54.450,78$ & $-36.267,46$ \\
\hline 18 & 80 & 1,25 & 3,81 & gérb1 & $-198.070,40$ & $-291.001,80$ & $374.473,30$ & $8.086,69$ & $150.016,27$ & $3.471,49$ & $176.402,88$ & $57.084,88$ \\
\hline 19 & 80 & 1,40 & 1,50 & gérb1 & $2.248,50$ & $-235.674,50$ & $7.430,43$ & $7.042,00$ & $-35.206,51$ & $-88.244,03$ & $-24.818,08$ & $-98.632,46$ \\
\hline 20 & 80 & 1,40 & 2,41 & gérb1 & $-182.420,80$ & $-256.950,20$ & $236.871,56$ & $0.180,82$ & $37.760,04$ & $-20.078,60$ & $54.450,78$ & $-36.769,35$ \\
\hline 21 & 80 & 1,40 & 3,81 & gérb1 & $-198.070,40$ & $-291.795,30$ & $374.473,30$ & $18.086,69$ & $150.016,27$ & $82.678,04$ & $176.402,88$ & $56.291,43$ \\
\hline 22 & 80 & 1,50 & 1,50 & gérb1 & $-172.248,50$ & $-235.882,70$ & $147.430,43$ & $137.042,00$ & $-35.206,51$ & $-88.452,28$ & $-24.818,08$ & $-98.840,71$ \\
\hline 23 & 80 & 1,50 & 2,41 & gérb1 & $-182.420,80$ & $-257.284,80$ & $236.871,56$ & $220.180,82$ & $37.760,04$ & $-20.413,20$ & $54.450,78$ & $-37.103,94$ \\
\hline 24 & 80 & 1,50 & 3,81 & gérb1 & $-198.070,40$ & $-292.324,20$ & $374.473,30$ & $348.086,69$ & $150.016,27$ & $82.149,08$ & $176.402,88$ & $55.762,47$ \\
\hline 25 & 100 & 1,10 & 1,50 & gérb1 & $-171.753,20$ & $-230.356,30$ & $147.430,43$ & $137.042,00$ & $-34.711,22$ & $-82.925,89$ & $-24.322,79$ & $-93.314,32$ \\
\hline 26 & 100 & 1,10 & 2,41 & gérb1 & $-181.925,50$ & $-250.684,50$ & $236.871,56$ & $220.180,82$ & $38.255,33$ & $-13.812,99$ & $54.946,07$ & $-30.503,73$ \\
\hline 27 & 100 & 1,10 & 3,81 & gérb1 & $-197.575,10$ & $-284.072,00$ & $374.473,30$ & $348.086,69$ & $150.511,55$ & $90.401,31$ & $176.898,17$ & $64.014,69$ \\
\hline 28 & 100 & 1,25 & 1,50 & gérb1 & $-171.753,20$ & $-230.668,70$ & $147.430,43$ & $137.042,00$ & $-34.711,22$ & $-83.238,27$ & $-24.322,79$ & $-93.626,70$ \\
\hline 29 & 100 & 1,25 & 2,41 & gérb1 & $-181.925,50$ & $-251.186,40$ & $236.871,56$ & $220.180,82$ & $38.255,33$ & $-14.314,88$ & $54.946,07$ & $-31.005,62$ \\
\hline 30 & 100 & 1,25 & 3,81 & gérb1 & $-197.575,10$ & $-284.865,40$ & $374.473,30$ & $348.086,69$ & $150.511,55$ & $89.607,86$ & $176.898,17$ & $63.221,25$ \\
\hline 31 & 100 & 1,40 & 1,50 & gérb1 & $-171.753,20$ & $-230.981,10$ & $147.430,43$ & $137.042,00$ & $-34.711,22$ & $-83.550,65$ & $-24.322,79$ & $-93.939,08$ \\
\hline 32 & 100 & 1,40 & 2,41 & gérb1 & -181. & $-251.688,30$ & $236.871,56$ & $220.180,82$ & $38.255,33$ & $-14.816,77$ & $54.946,07$ & $-31.507,51$ \\
\hline 33 & 100 & 1,40 & 3,81 & gérb1 & -197.57 & $-285.658,90$ & $374.473,30$ & $348.086,69$ & $150.511,55$ & $88.814,42$ & $176.898,17$ & $62.427,80$ \\
\hline 34 & 100 & 1,50 & 1,50 & gérb1 & $-171.753,20$ & $-231.189,30$ & $147.430,43$ & $137.042,00$ & $-34.711,22$ & $-83.758,90$ & $-24.322,79$ & $-94.147,33$ \\
\hline 35 & 100 & 1,50 & 2,41 & gérb1 & $-181.925,50$ & $-252.022,90$ & $236.871,56$ & $220.180,82$ & $38.255,33$ & $-15.151,36$ & $54.946,07$ & $-31.842,11$ \\
\hline 36 & 100 & 1,50 & 3,81 & gérb1 & $-197.575,10$ & $-286.187,80$ & $374.473,30$ & $348.086,69$ & $150.511,55$ & $88.285,45$ & $176.898,17$ & $61.898,84$ \\
\hline 1 & 75 & 1,10 & 1,50 & gérb2 & $-220.975,80$ & $-373.335,30$ & $380.977,69$ & $354.054,00$ & $133.078,19$ & $7.642,36$ & $160.001,89$ & $-19.281,34$ \\
\hline 2 & 75 & 1,10 & 2,41 & gérb2 & $-238.904,90$ & $-419.224,60$ & $612.104,16$ & $568.846,76$ & $329.941,83$ & $192.879,58$ & $373.199,23$ & $149.622,18$ \\
\hline 3 & 75 & 1,10 & 3,81 & gérb2 & $-266.488,20$ & $-491.936,70$ & $967.683,34$ & $899.297,16$ & $632.808,96$ & $475.746,69$ & $701.195,14$ & $407.360,51$ \\
\hline
\end{tabular}


Tabela 12. Principais resultados obtidos das simulações do quarto cenário logístico para a cadeia como um todo

\begin{tabular}{|c|c|c|c|c|c|c|c|c|c|c|c|c|}
\hline $\begin{array}{l}\text { Simu- } \\
\text { Lação }\end{array}$ & $\begin{array}{l}\text { Núme- } \\
\text { ro de } \\
\text { hastes }\end{array}$ & $\begin{array}{c}\text { Frete } \\
\text { aéreo } \\
\text { (US\$/ } \\
\mathrm{kg} \text { ) }\end{array}$ & $\begin{array}{l}\text { Taxa } \\
\text { câm- } \\
\text { bio } \\
\text { (R\$/ } \\
\text { US\$) } \\
\end{array}$ & $\begin{array}{l}\text { Tipo } \\
\text { de } \\
\text { flor }\end{array}$ & $\begin{array}{c}\text { Custo total } \\
\mathrm{s} / \text { insumo } \\
\text { logístico }\end{array}$ & $\begin{array}{l}\text { Custo total } \\
\mathrm{c} / \text { insumo } \\
\text { logístico }\end{array}$ & $\begin{array}{c}\text { Receita total } \\
\mathrm{s} / \text { produto } \\
\text { logístico }\end{array}$ & $\begin{array}{c}\text { Receita total } \\
\mathrm{c} / \text { produto } \\
\text { logístico }\end{array}$ & $\begin{array}{l}\text { Lucro total } \\
\mathrm{c} / \text { produto } \\
\text { logístico }\end{array}$ & $\begin{array}{l}\text { Lucro total } \\
\mathrm{c} / \text { insumo } \\
\text { logístico }\end{array}$ & $\begin{array}{c}\text { Lucro total } \\
\text { s/ produto } \\
\text { e.insumo } \\
\text { logísticos }\end{array}$ & $\begin{array}{l}\text { Lucro total } \\
\mathrm{c} / \text { insumo } \\
\text { e.produto } \\
\text { logísticos }\end{array}$ \\
\hline 4 & 75 & 1,25 & 1,50 & gérb2 & $-220.975,80$ & $-374.388,60$ & $380.977,69$ & $354.054,00$ & $133.078,19$ & $6.589,12$ & $160.001,89$ & $-20.334,58$ \\
\hline 5 & 75 & 1,25 & 2,41 & gérb2 & $-238.904,90$ & $-420.916,80$ & $612.104,16$ & $568.846,76$ & $329.941,83$ & $191.187,38$ & $373.199,23$ & $147.929,98$ \\
\hline 6 & 75 & 1,25 & 3,81 & gérb2 & $-266.488,20$ & $-494.611,90$ & $967.683,34$ & $899.297,16$ & $632.808,96$ & $473.071,46$ & $701.195,14$ & $404.685,28$ \\
\hline 7 & 75 & 1,40 & 1,50 & gérb2 & $-220.975,80$ & $-375.441,80$ & $380.977,69$ & $354.054,00$ & $133.078,19$ & $5.535,88$ & $160.001,89$ & $-21.387,82$ \\
\hline 8 & 75 & 1,40 & 2,41 & gérb2 & $-238.904,90$ & $-422.609,00$ & $612.104,16$ & $568.846,76$ & $329.941,83$ & $189.495,17$ & $373.199,23$ & $146.237,77$ \\
\hline 9 & 75 & 1,40 & 3,81 & gérb2 & $-266.488,20$ & $-497.287,10$ & $967.683,34$ & $899.297,16$ & $632.808,96$ & $470.396,23$ & $701.195,14$ & $402.010,05$ \\
\hline 10 & 75 & 1,50 & 1,50 & gérb2 & $-220.975,80$ & $-376.144,00$ & $380.977,69$ & $354.054,00$ & $133.078,19$ & $4.833,72$ & $160.001,89$ & $-22.089,98$ \\
\hline 11 & 75 & 1,50 & 2,41 & gérb2 & $-238.904,90$ & $-423.737,10$ & $612.104,16$ & $568.846,76$ & $329.941,83$ & $188.367,04$ & $373.199,23$ & $145.109,64$ \\
\hline 12 & 75 & 1,50 & 3,81 & gérb2 & $-266.488,20$ & $-499.070,60$ & $967.683,34$ & $899.297,16$ & $632.808,96$ & $468.612,75$ & $701.195,14$ & $400.226,57$ \\
\hline 13 & 80 & 1,10 & 1,50 & gérb2 & $-220.419,20$ & $-367.754,00$ & $380.977,69$ & $354.054,00$ & $133.634,84$ & $13.223,65$ & $160.558,53$ & $-13.700,04$ \\
\hline 14 & 80 & 1,10 & 2,41 & gérb2 & $-238.348,30$ & $-413.004,40$ & $612.104,16$ & $568.846,76$ & $330.498,47$ & $199.099,75$ & $373.755,87$ & $155.842,35$ \\
\hline 15 & 80 & 1,10 & 3,81 & gérb2 & $-265.931,60$ & $-484.733,60$ & $967.683,34$ & $899.297,16$ & $633.365,61$ & $482.949,74$ & $701.751,79$ & $414.563,56$ \\
\hline 16 & 80 & 1,25 & 1,50 & gérb2 & $-220.419,20$ & $-368.807,30$ & $380.977,69$ & $354.054,00$ & $133.634,84$ & $12.170,41$ & $160.558,53$ & $-14.753,28$ \\
\hline 17 & 80 & 1,25 & 2,41 & gérb2 & & $-414.696,60$ & & & $330.498,47$ & & & $154.150,15$ \\
\hline 18 & 80 & 1,25 & 3,81 & gérb2 & & & & & & $480.274,51$ & & $411.888,33$ \\
\hline 19 & 80 & 1,40 & 1,50 & gérb2 & & & & & & $11.117,17$ & $160.558,53$ & $-15.806,52$ \\
\hline 20 & 80 & 1,40 & 2,41 & & & & & & $330.498,47$ & $195.715,34$ & $373.755,87$ & $152.457,94$ \\
\hline 21 & 80 & 1,40 & 3,81 & & $-265.931,60$ & $-490.084,10$ & $967.683,34$ & $899.297,16$ & $633.365,61$ & $477.599,29$ & $701.751,79$ & $409.213,11$ \\
\hline 22 & 80 & 1,50 & 1,50 & gérb2 & $-220.419,20$ & $-370.562,70$ & $380.977,69$ & $354.054,00$ & $133.634,84$ & $10.415,01$ & $160.558,53$ & $-16.508,68$ \\
\hline 23 & 80 & 1,50 & 2,41 & gérb2 & $-238.348,30$ & $-417.517,00$ & $612.104,16$ & $568.846,76$ & $330.498,47$ & $194.587,21$ & $373.755,87$ & $151.329,81$ \\
\hline 24 & 80 & 1,50 & 3,81 & gérb2 & $-265.931,60$ & $-491.867,50$ & $967.683,34$ & $899.297,16$ & $633.365,61$ & $475.815,80$ & $701.751,79$ & $407.429,62$ \\
\hline 25 & 100 & 1,10 & 1,50 & gérb2 & $-218.749,20$ & $-351.010,20$ & $380.977,69$ & $354.054,00$ & $135.304,77$ & $29.967,54$ & $162.228,46$ & $3.043,84$ \\
\hline 26 & 100 & 1,10 & 2,41 & gérb2 & $-236.678,40$ & $-394.343,90$ & $612.104,16$ & $568.846,76$ & $332.168,41$ & $217.760,26$ & $375.425,81$ & $174.502,86$ \\
\hline 27 & 100 & 1,10 & 3,81 & gérb2 & $-264.261,60$ & $-463.124,40$ & $967.683,34$ & $899.297,16$ & $635.035,54$ & $504.558,90$ & $703.421,72$ & $436.172,72$ \\
\hline 28 & 100 & 1,25 & 1,50 & gérb2 & $-218.749,20$ & $-352.063,40$ & $380.977,69$ & $354.054,00$ & $135.304,77$ & $28.914,30$ & $162.228,46$ & $1.990,60$ \\
\hline
\end{tabular}


Tabela 12. Principais resultados obtidos das simulações do quarto cenário logístico para a cadeia como um todo

\begin{tabular}{|c|c|c|c|c|c|c|c|c|c|c|c|c|}
\hline $\begin{array}{l}\text { Simu- } \\
\text { Lação }\end{array}$ & $\begin{array}{l}\text { Núme- } \\
\text { ro de } \\
\text { hastes }\end{array}$ & $\begin{array}{c}\text { Frete } \\
\text { aéreo } \\
\text { (US\$/ } \\
\mathrm{kg} \text { ) }\end{array}$ & $\begin{array}{l}\text { Taxa } \\
\text { câm- } \\
\text { bio } \\
\text { (R\$/ } \\
\text { US\$) }\end{array}$ & $\begin{array}{l}\text { Tipo } \\
\text { de } \\
\text { flor }\end{array}$ & $\begin{array}{c}\text { Custo total } \\
\mathrm{s} / \text { insumo } \\
\text { logístico }\end{array}$ & $\begin{array}{c}\text { Custo total } \\
\mathrm{c} / \text { insumo } \\
\text { logístico }\end{array}$ & $\begin{array}{c}\text { Receita total } \\
\mathrm{s} / \text { produto } \\
\text { logístico }\end{array}$ & $\begin{array}{c}\text { Receita total } \\
\mathrm{c} / \text { produto } \\
\text { logístico }\end{array}$ & $\begin{array}{c}\text { Lucro total } \\
\mathrm{c} / \text { produto } \\
\text { logístico }\end{array}$ & $\begin{array}{c}\text { Lucro total } \\
\mathrm{c} / \text { insumo } \\
\text { logístico }\end{array}$ & $\begin{array}{l}\text { Lucro total } \\
\text { s/ produto } \\
\text { e.insumo } \\
\text { logísticos }\end{array}$ & $\begin{array}{l}\text { Lucro total } \\
\text { c/ insumo } \\
\text { e.produto } \\
\text { logísticos }\end{array}$ \\
\hline 29 & 100 & 1,25 & 2,41 & gérb2 & $-236.678,40$ & $-396.036,10$ & $612.104,16$ & $568.846,76$ & $332.168,41$ & $216.068,05$ & $375.425,81$ & $172.810,66$ \\
\hline 30 & 100 & 1,25 & 3,81 & gérb2 & 51,60 & $-465.799,70$ & & $9.297,16$ & 5,54 & $501.883,67$ & $703.421,72$ & $433.497,49$ \\
\hline 31 & 100 & 1,40 & 1,50 & gérb2 & $-218.749,20$ & $-353.116,60$ & $380.977,69$ & $354.054,00$ & $135.304,77$ & $27.861,06$ & $162.228,46$ & 937,36 \\
\hline 32 & 100 & 1,40 & 2,41 & gérb2 & $-236.678,40$ & $-397.728,30$ & $612.104,16$ & $568.846,76$ & $332.168,41$ & $214.375,85$ & $375.425,81$ & $171.118,45$ \\
\hline 33 & 100 & 1,40 & 3,81 & gérb2 & $-264.261,60$ & $-468.474,90$ & $967.683,34$ & $899.297,16$ & $635.035,54$ & $499.208,44$ & $703.421,72$ & $430.822,26$ \\
\hline 34 & 100 & 1,50 & 1,50 & gérb2 & $-218.749,20$ & $-353.818,80$ & $380.977,69$ & $354.054,00$ & $135.304,77$ & $27.158,90$ & $162.228,46$ & 235,20 \\
\hline 35 & 100 & 1,50 & 2,41 & gérb2 & $-236.678,40$ & $-398.856,40$ & $612.104,16$ & $568.846,76$ & $332.168,41$ & $213.247,71$ & $375.425,81$ & $169.990,31$ \\
\hline 36 & 100 & 1,50 & 3,81 & gérb2 & $-264.261,60$ & $-470.258,40$ & $967.683,34$ & $899.297,16$ & $635.035,54$ & $497.424,96$ & $703.421,72$ & $429.038,78$ \\
\hline
\end{tabular}


Tabela 13. Principais resultados obtidos das simulações do quinto cenário logístico para a cadeia como um todo

\begin{tabular}{|c|c|c|c|c|c|c|c|c|c|c|c|c|}
\hline $\begin{array}{l}\text { Simu- } \\
\text { Lação }\end{array}$ & $\begin{array}{l}\text { Núme- } \\
\text { ro de } \\
\text { hastes } \\
\end{array}$ & $\begin{array}{c}\text { Frete } \\
\text { aéreo } \\
\text { (US\$/ } \\
\mathrm{kg} \text { ) }\end{array}$ & $\begin{array}{c}\text { Taxa } \\
\text { câm- } \\
\text { bio } \\
\text { (R\$/ } \\
\text { US\$) } \\
\end{array}$ & $\begin{array}{l}\text { Tipo } \\
\text { de } \\
\text { flor }\end{array}$ & $\begin{array}{c}\text { Custo total } \\
\mathrm{s} / \text { insumo } \\
\text { logístico }\end{array}$ & $\begin{array}{l}\text { Custo total } \\
\mathrm{c} / \text { insumo } \\
\text { logístico }\end{array}$ & $\begin{array}{c}\text { Receita total } \\
\mathrm{s} / \text { produto } \\
\text { logístico } \\
\end{array}$ & $\begin{array}{c}\text { Receita total } \\
\mathrm{c} / \text { produto } \\
\text { logístico }\end{array}$ & $\begin{array}{c}\text { Lucro total } \\
\mathrm{c} / \text { produto } \\
\text { logístico }\end{array}$ & $\begin{array}{l}\text { Lucro total } \\
\mathrm{c} / \text { insumo } \\
\text { logístico }\end{array}$ & $\begin{array}{l}\text { Lucro total } \\
\text { s/ produto } \\
\text { e.insumo } \\
\text { logísticos }\end{array}$ & $\begin{array}{l}\text { Lucro total } \\
\text { c/ insumo } \\
\text { e.produto } \\
\text { logísticos }\end{array}$ \\
\hline 1 & 75 & 1,10 & 1,50 & Lírio & $-836.587,60$ & $-1.173 .245,00$ & $1.076 .065,60$ & $997.539,88$ & $160.952,23$ & $-97.179,29$ & $239.477,97$ & $-175.705,00$ \\
\hline 2 & 75 & 1,10 & 2,41 & lírio & $-931.901,50$ & $-1.357 .087,00$ & $1.728 .878,80$ & $1.602 .714,10$ & $670.812,56$ & $371.791,54$ & $796.977,24$ & $245.626,86$ \\
\hline 3 & 75 & 1,10 & 3,81 & lírio & $-1.172 .010,00$ & $-1.735 .506,00$ & $2.733 .206,70$ & $2.533 .751,30$ & $1.361 .741,50$ & $997.700,29$ & $1.561 .196,80$ & $798.244,91$ \\
\hline 4 & 75 & 1,25 & 1,50 & lírio & $-836.587,60$ & $-1.174 .523,00$ & $1.076 .065,60$ & $997.539,88$ & $160.952,23$ & $-98.457,18$ & $239.477,97$ & $-176.982,90$ \\
\hline 5 & 75 & 1,25 & 2,41 & lírio & $-931.901,50$ & $-1.359 .140,00$ & $1.728 .878,80$ & $1.602 .714,10$ & $670.812,56$ & $369.738,41$ & $796.977,24$ & $243.573,72$ \\
\hline 6 & 75 & 1,25 & 3,81 & lírio & $-1.172 .010,00$ & $-1.738 .752,00$ & $2.733 .206,70$ & $2.533 .751,30$ & $1.361 .741,50$ & $994.454,46$ & $1.561 .196,80$ & $794.999,09$ \\
\hline 7 & 75 & 1,40 & 1,50 & lírio & $-836.587,60$ & $-1.175 .801,00$ & $1.076 .065,60$ & $997.539,88$ & $160.952,23$ & $-99.735,06$ & $239.477,97$ & $-178.260,80$ \\
\hline 8 & 75 & 1,40 & 2,41 & lírio & $-931.901,50$ & $-1.361 .193,00$ & $1.728 .878,80$ & $1.602 .714,10$ & $670.812,56$ & $367.685,28$ & $796.977,24$ & $241.520,59$ \\
\hline 9 & 75 & 1,40 & 3,81 & lírio & $-1.172 .010,00$ & $-1.741 .998,00$ & $2.733 .206,70$ & $2.533 .751,30$ & $1.361 .741,50$ & $91.208,64$ & $1.561 .196,80$ & $991.753,27$ \\
\hline 10 & 75 & 1,50 & 1,50 & lírio & $-836.587,60$ & $-1.176 .653,00$ & $1.076 .065,60$ & $997.539,88$ & & $-100.587,00$ & $39.477,97$ & $-179.112,70$ \\
\hline 11 & 75 & 1,50 & 2,41 & lírio & $-931.901,50$ & $-1.362 .562,00$ & $1.728 .878,80$ & $1.602 .714,10$ & $670.812,56$ & $366.316,52$ & $796.977,24$ & $240.151,84$ \\
\hline 12 & 75 & 1,50 & 3,81 & lírio & $-1.172 .010,00$ & $-1.744 .162,00$ & $2.733 .206,70$ & $2.533 .751,30$ & $1.361 .741,50$ & $989.044,76$ & $1.561 .196,80$ & $789.589,38$ \\
\hline 13 & 80 & 1,10 & 1,50 & lírio & $-836.662,80$ & $-1.159 .067,00$ & $1.076 .065,60$ & $997.539,88$ & $160.877,10$ & $-83.001,25$ & $239.402,84$ & $-161.527,00$ \\
\hline 14 & 80 & 1,10 & 2,41 & lírio & & & & & & $89.302,33$ & & $263.137,65$ \\
\hline 15 & 80 & 1,10 & 3,81 & lírio & & & & $2.533 .751,30$ & 1.361 .6 & $1.020 .338,40$ & $1.561 .121,70$ & $.883,01$ \\
\hline 16 & 80 & 1,25 & 1,50 & lírio & & & 1.076 .0 & $997.539,88$ & $160.877,10$ & $-84.279,14$ & $239.402,84$ & $-162.804,90$ \\
\hline 17 & 80 & 1,25 & 2,41 & lírio & -931.9 & $-1.341 .630,00$ & $1.728 .878,80$ & $1.602 .714,10$ & $670.737,43$ & $387.249,20$ & $796.902,12$ & $261.084,52$ \\
\hline 18 & 80 & 1,25 & 3,81 & lírio & $-1.172 .085,00$ & $-1.716 .114,00$ & $2.733 .206,70$ & $2.533 .751,30$ & $1.361 .666,30$ & $1.017 .092,60$ & $1.561 .121,70$ & $817.637,19$ \\
\hline 19 & 80 & 1,40 & 1,50 & lírio & $-836.662,80$ & $-1.161 .623,00$ & $1.076 .065,60$ & $997.539,88$ & $160.877,10$ & $-85.557,02$ & $239.402,84$ & $-164.082,80$ \\
\hline 20 & 80 & 1,40 & 2,41 & lírio & $-931.976,60$ & $-1.343 .683,00$ & $1.728 .878,80$ & $1.602 .714,10$ & $670.737,43$ & $385.196,07$ & $796.902,12$ & $259.031,38$ \\
\hline 21 & 80 & 1,40 & 3,81 & lírio & $-1.172 .085,00$ & $-1.719 .360,00$ & $2.733 .206,70$ & $2.533 .751,30$ & $1.361 .666,30$ & $1.013 .846,70$ & $1.561 .121,70$ & $814.391,37$ \\
\hline 22 & 80 & 1,50 & 1,50 & lírio & $-836.662,80$ & $-1.162 .475,00$ & $1.076 .065,60$ & $997.539,88$ & $160.877,10$ & $-86.408,94$ & $239.402,84$ & $-164.934,70$ \\
\hline 23 & 80 & 1,50 & 2,41 & lírio & $-931.976,60$ & $-1.345 .051,00$ & $1.728 .878,80$ & $1.602 .714,10$ & $670.737,43$ & $383.827,31$ & $796.902,12$ & $257.662,63$ \\
\hline 24 & 80 & 1,50 & 3,81 & lírio & $-1.172 .085,00$ & $-1.721 .524,00$ & $2.733 .206,70$ & $2.533 .751,30$ & $1.361 .666,30$ & $1.011 .682,90$ & $1.561 .121,70$ & $812.227,48$ \\
\hline 25 & 100 & 1,10 & 1,50 & lírio & $-836.888,10$ & $-1.116 .533,00$ & $1.076 .065,60$ & $997.539,88$ & $160.651,73$ & $-40.467,13$ & $239.177,46$ & $-118.992,90$ \\
\hline
\end{tabular}


Tabela 13. Principais resultados obtidos das simulações do quinto cenário logístico para a cadeia como um todo

\begin{tabular}{|c|c|c|c|c|c|c|c|c|c|c|c|c|}
\hline $\begin{array}{l}\text { Simu- } \\
\text { Lação }\end{array}$ & $\begin{array}{l}\text { Núme- } \\
\text { ro de } \\
\text { hastes }\end{array}$ & $\begin{array}{c}\text { Frete } \\
\text { aéreo } \\
\text { (US\$/ } \\
\mathrm{kg})\end{array}$ & $\begin{array}{l}\text { Taxa } \\
\text { câm- } \\
\text { bio } \\
\text { (R\$/ } \\
\text { US\$) } \\
\end{array}$ & $\begin{array}{l}\text { Tipo } \\
\text { de } \\
\text { flor }\end{array}$ & $\begin{array}{l}\text { Custo total } \\
\mathrm{s} / \text { insumo } \\
\text { logístico }\end{array}$ & $\begin{array}{l}\text { Custo total } \\
\mathrm{c} / \text { insumo } \\
\text { logístico }\end{array}$ & $\begin{array}{c}\text { Receita total } \\
\mathrm{s} / \text { produto } \\
\text { logístico }\end{array}$ & $\begin{array}{c}\text { Receita total } \\
\mathrm{c} / \text { produto } \\
\text { logístico }\end{array}$ & $\begin{array}{l}\text { Lucro total } \\
\mathrm{c} / \text { produto } \\
\text { logístico }\end{array}$ & $\begin{array}{l}\text { Lucro total } \\
\mathrm{c} / \text { insumo } \\
\text { logístico }\end{array}$ & $\begin{array}{l}\text { Lucro total } \\
\text { s/ produto } \\
\text { e.insumo } \\
\text { logísticos }\end{array}$ & $\begin{array}{l}\text { Lucro total } \\
\text { c/ insumo } \\
\text { e.produto } \\
\text { logísticos }\end{array}$ \\
\hline 26 & 100 & 1,10 & 2,41 & lírio & $-932.202,00$ & $-1.287 .044,00$ & $1.728 .878,80$ & $1.602 .714,10$ & $670.512,06$ & $441.834,71$ & $796.676,74$ & $315.670,02$ \\
\hline 27 & 100 & 1,10 & 3,81 & lírio & $-1.172 .310,00$ & $-1.644 .954,00$ & $2.733 .206,70$ & $2.533 .751,30$ & $1.361 .441,00$ & $1.088 .252,70$ & $1.560 .896,30$ & $888.797,31$ \\
\hline 28 & 100 & 1,25 & 1,50 & lírio & $-836.888,10$ & $-1.117 .811,00$ & $1.076 .065,60$ & $997.539,88$ & $160.651,73$ & $-41.745,01$ & $239.177,46$ & $-120.270,80$ \\
\hline 29 & 100 & 1,25 & 2,41 & lírio & $-932.202,00$ & $-1.289 .097,00$ & $1.728 .878,80$ & $1.602 .714,10$ & $670.512,06$ & $439.781,58$ & $796.676,74$ & $313.616,89$ \\
\hline 30 & 100 & 1,25 & 3,81 & lírio & $-1.172 .310,00$ & $-1.648 .200,00$ & $2.733 .206,70$ & $2.533 .751,30$ & $1.361 .441,00$ & $1.085 .006,90$ & $1.560 .896,30$ & $885.551,49$ \\
\hline 31 & 100 & 1,40 & 1,50 & lírio & $-836.888,10$ & $-1.119 .089,00$ & $1.076 .065,60$ & $997.539,88$ & $160.651,73$ & $-43.022,90$ & $239.177,46$ & $-121.548,60$ \\
\hline 32 & 100 & 1,40 & 2,41 & lírio & $-932.202,00$ & $-1.291 .150,00$ & $1.728 .878,80$ & $1.602 .714,10$ & $670.512,06$ & $437.728,44$ & $796.676,74$ & $311.563,76$ \\
\hline 33 & 100 & 1,40 & 3,81 & lírio & $-1.172 .310,00$ & $-1.651 .446,00$ & $2.733 .206,70$ & $2.533 .751,30$ & $1.361 .441,00$ & $1.081 .761,00$ & $1.560 .896,30$ & $882.305,67$ \\
\hline 34 & 100 & 1,50 & 1,50 & lírio & $-836.888,10$ & $-1.119 .940,00$ & $1.076 .065,60$ & $997.539,88$ & $160.651,73$ & $-43.874,82$ & $239.177,46$ & $-122.400,60$ \\
\hline 35 & 100 & 1,50 & 2,41 & lírio & $-932.202,00$ & $-1.292 .519,00$ & $1.728 .878,80$ & $1.602 .714,10$ & $670.512,06$ & $436.359,69$ & $796.676,74$ & $310.195,00$ \\
\hline 36 & 100 & 1,50 & 3,81 & lírio & $-1.172 .310,00$ & $-1.653 .609,00$ & $2.733 .206,70$ & $2.533 .751,30$ & $1.361 .441,00$ & $1.079 .597,20$ & $1.560 .896,30$ & $880.141,79$ \\
\hline 1 & 75 & 1,10 & 1,50 & gérb1 & $-169.895,00$ & $-253.617,60$ & $145.328,23$ & $134.740,45$ & $-35.154,53$ & $-108.289,40$ & $-24.566,74$ & $-118.877,10$ \\
\hline 2 & 75 & 1,10 & 2,41 & gérb1 & $-180.330,90$ & $-285.524,80$ & $233.494,02$ & $216.482,98$ & $36.152,13$ & $-52.030,81$ & $53.163,17$ & $-69.041,85$ \\
\hline 3 & 75 & 1,10 & 3,81 & gérb1 & & & & & & & & $5.514,58$ \\
\hline 4 & 75 & 1,25 & 1,50 & gérb1 & & & & & & $-108.620,70$ & $-24.566,74$ & $-119.208,40$ \\
\hline 5 & 75 & 1,25 & 2,41 & & & & & $216.482,98$ & $36.152,13$ & $-52.563,12$ & $53.163,17$ & $-69.574,16$ \\
\hline 6 & 75 & 1,25 & 3,81 & & & -337 & $369.133,71$ & $342.240,73$ & $145.854,68$ & $31.566,02$ & $172.747,66$ & $4.673,04$ \\
\hline 7 & 75 & 1,40 & 1,50 & gérb1 & $-169.895,00$ & $-254.280,20$ & $145.328,23$ & $134.740,45$ & $-35.154,53$ & $-108.952,00$ & $-24.566,74$ & $-119.539,80$ \\
\hline 8 & 75 & 1,40 & 2,41 & gérb1 & -180.33 & $-286.589,50$ & $233.494,02$ & $216.482,98$ & $36.152,13$ & $-53.095,43$ & $53.163,17$ & $-70.106,47$ \\
\hline 9 & 75 & 1,40 & 3,81 & gérb1 & $-196.386,10$ & $-338.409,20$ & $369.133,71$ & $342.240,73$ & $145.854,68$ & $30.724,48$ & $172.747,66$ & $3.831,51$ \\
\hline 10 & 75 & 1,50 & 1,50 & gérb1 & $-169.895,00$ & $-254.501,10$ & $145.328,23$ & $134.740,45$ & $-35.154,53$ & $-109.172,90$ & $-24.566,74$ & $-119.760,60$ \\
\hline 11 & 75 & 1,50 & 2,41 & gérb1 & $-180.330,90$ & $-286.944,30$ & $233.494,02$ & $216.482,98$ & $36.152,13$ & $-53.450,30$ & $53.163,17$ & $-70.461,34$ \\
\hline 12 & 75 & 1,50 & 3,81 & gérb1 & $-196.386,10$ & $-338.970,20$ & $369.133,71$ & $342.240,73$ & $145.854,68$ & $30.163,46$ & $172.747,66$ & $3.270,49$ \\
\hline 13 & 80 & 1,10 & 1,50 & gérb1 & $-169.914,50$ & $-251.071,40$ & $145.328,23$ & $134.740,45$ & $-35.174,01$ & $-105.743,20$ & $-24.586,22$ & $-116.330,90$ \\
\hline 14 & 80 & 1,10 & 2,41 & gérb1 & $-180.350,30$ & $-282.114,60$ & $233.494,02$ & $216.482,98$ & $36.132,65$ & $-48.620,54$ & $53.143,69$ & $-65.631,59$ \\
\hline
\end{tabular}


Tabela 13. Principais resultados obtidos das simulações do quinto cenário logístico para a cadeia como um todo

\begin{tabular}{|c|c|c|c|c|c|c|c|c|c|c|c|c|}
\hline $\begin{array}{l}\text { Simu- } \\
\text { Lação }\end{array}$ & $\begin{array}{l}\text { Núme- } \\
\text { ro de } \\
\text { hastes }\end{array}$ & $\begin{array}{c}\text { Frete } \\
\text { aéreo } \\
\text { (US\$/ } \\
\mathrm{kg})\end{array}$ & $\begin{array}{l}\text { Taxa } \\
\text { câm- } \\
\text { bio } \\
\text { (R\$/ } \\
\text { US\$) } \\
\end{array}$ & $\begin{array}{l}\text { Tipo } \\
\text { de } \\
\text { flor }\end{array}$ & $\begin{array}{l}\text { Custo total } \\
\mathrm{s} / \text { insumo } \\
\text { logístico }\end{array}$ & $\begin{array}{l}\text { Custo total } \\
\mathrm{c} / \text { insumo } \\
\text { logístico }\end{array}$ & $\begin{array}{c}\text { Receita total } \\
\mathrm{s} / \text { produto } \\
\text { logístico }\end{array}$ & $\begin{array}{c}\text { Receita total } \\
\mathrm{c} / \text { produto } \\
\text { logístico }\end{array}$ & $\begin{array}{l}\text { Lucro total } \\
\mathrm{c} / \text { produto } \\
\text { logístico }\end{array}$ & $\begin{array}{l}\text { Lucro total } \\
\mathrm{c} / \text { insumo } \\
\text { logístico }\end{array}$ & $\begin{array}{l}\text { Lucro total } \\
\text { s/ produto } \\
\text { e.insumo } \\
\text { logísticos }\end{array}$ & $\begin{array}{l}\text { Lucro total } \\
\text { c/ insumo } \\
\text { e.produto } \\
\text { logísticos }\end{array}$ \\
\hline 15 & 80 & 1,10 & 3,81 & gérb1 & $-196.405,50$ & $-331.986,60$ & $369.133,71$ & $342.240,73$ & $145.835,20$ & $37.147,16$ & $172.728,18$ & $10.254,18$ \\
\hline 16 & 80 & 1,25 & 1,50 & gérb1 & $-169.914,50$ & $-251.402,70$ & $145.328,23$ & $134.740,45$ & $-35.174,01$ & $-106.074,50$ & $-24.586,22$ & $-116.662,30$ \\
\hline 17 & 80 & 1,25 & 2,41 & gérb1 & $-180.350,30$ & $-282.646,90$ & $233.494,02$ & $216.482,98$ & $36.132,65$ & $-49.152,85$ & $53.143,69$ & $-66.163,89$ \\
\hline 18 & 80 & 1,25 & 3,81 & gérb1 & $-196.405,50$ & $-332.828,10$ & $369.133,71$ & $342.240,73$ & $145.835,20$ & $36.305,62$ & $172.728,18$ & $9.412,65$ \\
\hline 19 & 80 & 1,40 & 1,50 & gérb1 & $-169.914,50$ & $-251.734,00$ & $145.328,23$ & $134.740,45$ & $-35.174,01$ & $-106.405,80$ & $-24.586,22$ & $-116.993,60$ \\
\hline 20 & 80 & 1,40 & 2,41 & gérb1 & $-180.350,30$ & $-283.179,20$ & $233.494,02$ & $216.482,98$ & $36.132,65$ & $-49.685,16$ & $53.143,69$ & $-66.696,20$ \\
\hline 21 & 80 & 1,40 & 3,81 & gérb1 & $-196.405,50$ & $-333.669,60$ & $369.133,71$ & $342.240,73$ & $145.835,20$ & $35.464,09$ & $172.728,18$ & $8.571,12$ \\
\hline 22 & 80 & 1,50 & 1,50 & gérb1 & $-169.914,50$ & $-251.954,90$ & $145.328,23$ & $134.740,45$ & $-35.174,01$ & $-106.626,70$ & $-24.586,22$ & $-117.214,40$ \\
\hline 23 & 80 & 1,50 & 2,41 & gérb1 & $-180.350,30$ & $-283.534,10$ & $233.494,02$ & $216.482,98$ & $36.132,65$ & $-50.040,03$ & $53.143,69$ & $-67.051,07$ \\
\hline 24 & 80 & 1,50 & 3,81 & gérb1 & $-196.405,50$ & $-334.230,60$ & $369.133,71$ & $2.240,73$ & $145.835,20$ & $34.903,07$ & $172.728,18$ & $8.010,09$ \\
\hline 25 & 100 & 1,10 & 1,50 & gérb1 & $-169.972,90$ & $-243.432,80$ & $145.328,23$ & $134.740,45$ & $-35.232,44$ & $-98.104,57$ & $-24.644,65$ & $-108.692,40$ \\
\hline 26 & 100 & 1,10 & 2,41 & gérb1 & $-180.408,80$ & $-271.883,80$ & $233.494,02$ & $216.482,98$ & $36.074,22$ & $-38.389,74$ & $53.085,26$ & $-55.400,78$ \\
\hline 27 & 100 & 1,10 & 3,81 & gérb1 & $-196.464,00$ & $-317.767,70$ & $369.133,71$ & $342.240,73$ & $145.776,77$ & $51.365,98$ & $172.669,75$ & $24.473,00$ \\
\hline 28 & 100 & 1,25 & 1,50 & gérb1 & $-169.972,90$ & $-243.764,10$ & $145.328,23$ & $134.740,45$ & $-35.232,44$ & $-98.435,88$ & $-24.644,65$ & $-109.023,70$ \\
\hline 29 & 100 & 1,25 & 2,41 & gérb1 & & & & 216.4 & & $-38.922,05$ & $53.085,26$ & $-55.933,09$ \\
\hline 30 & 100 & 1,25 & 3,81 & & & & 369. & 342. & & & $172.669,75$ & $23.631,47$ \\
\hline 31 & 100 & 1,40 & 1,50 & & & & & & -35.2 & $-98.767,19$ & $-24.644,65$ & $-109.355,00$ \\
\hline 32 & 100 & 1,40 & 2,41 & gérb1 & $-180.408,80$ & & & & $36.074,22$ & $-39.454,36$ & $53.085,26$ & $-56.465,40$ \\
\hline 33 & 100 & 1,40 & 3,81 & gérb1 & $-196.464,00$ & $-319.450,80$ & $369.133,71$ & $342.240,73$ & $145.776,77$ & $49.682,91$ & $172.669,75$ & $22.789,93$ \\
\hline 34 & 100 & 1,50 & 1,50 & gérb1 & $-169.972,90$ & $-244.316,30$ & $145.328,23$ & $134.740,45$ & $-35.232,44$ & $-98.988,07$ & $-24.644,65$ & $-109.575,90$ \\
\hline 35 & 100 & 1,50 & 2,41 & gérb1 & $-180.408,80$ & $-273.303,30$ & $233.494,02$ & $216.482,98$ & $36.074,22$ & $-39.809,23$ & $53.085,26$ & $-56.820,27$ \\
\hline 36 & 100 & 1,50 & 3,81 & gérb1 & $-196.464,00$ & $-320.011,80$ & $369.133,71$ & $342.240,73$ & $145.776,77$ & $49.121,89$ & $172.669,75$ & $22.228,91$ \\
\hline 1 & 75 & 1,10 & 1,50 & gérb2 & $-212.193,10$ & $-428.532,20$ & $376.486,57$ & $348.978,04$ & $136.784,99$ & $-52.045,65$ & $164.293,52$ & $-79.554,18$ \\
\hline 2 & 75 & 1,10 & 2,41 & gérb2 & $-230.836,20$ & $-511.162,50$ & $604.888,43$ & $560.691,39$ & $329.855,20$ & $93.725,96$ & $374.052,24$ & $49.528,92$ \\
\hline 3 & 75 & 1,10 & 3,81 & gérb2 & $-259.517,90$ & $-640.399,20$ & $956.275,90$ & $886.404,23$ & $626.886,30$ & $315.876,73$ & $696.757,97$ & $246.005,06$ \\
\hline
\end{tabular}


Tabela 13. Principais resultados obtidos das simulações do quinto cenário logístico para a cadeia como um todo

\begin{tabular}{|c|c|c|c|c|c|c|c|c|c|c|c|c|}
\hline $\begin{array}{l}\text { Simu- } \\
\text { Lação }\end{array}$ & $\begin{array}{l}\text { Núme- } \\
\text { ro de } \\
\text { hastes }\end{array}$ & $\begin{array}{c}\text { Frete } \\
\text { aéreo } \\
\text { (US\$/ } \\
\mathrm{kg})\end{array}$ & $\begin{array}{l}\text { Taxa } \\
\text { câm- } \\
\text { bio } \\
\text { (R\$/ } \\
\text { US\$) } \\
\end{array}$ & $\begin{array}{l}\text { Tipo } \\
\text { de } \\
\text { flor }\end{array}$ & $\begin{array}{l}\text { Custo total } \\
\mathrm{s} / \text { insumo } \\
\text { logístico }\end{array}$ & $\begin{array}{l}\text { Custo total } \\
\mathrm{c} / \text { insumo } \\
\text { logístico }\end{array}$ & $\begin{array}{c}\text { Receita total } \\
\mathrm{s} / \text { produto } \\
\text { logístico }\end{array}$ & $\begin{array}{c}\text { Receita total } \\
\mathrm{c} / \text { produto } \\
\text { logístico }\end{array}$ & $\begin{array}{l}\text { Lucro total } \\
\mathrm{c} / \text { produto } \\
\text { logístico }\end{array}$ & $\begin{array}{l}\text { Lucro total } \\
\mathrm{c} / \text { insumo } \\
\text { logístico }\end{array}$ & $\begin{array}{l}\text { Lucro total } \\
\text { s/ produto } \\
\text { e.insumo } \\
\text { logísticos }\end{array}$ & $\begin{array}{l}\text { Lucro total } \\
\text { c/ insumo } \\
\text { e.produto } \\
\text { logísticos }\end{array}$ \\
\hline 4 & 75 & 1,25 & 1,50 & gérb2 & $-212.193,10$ & $-429.652,10$ & $376.486,57$ & $348.978,04$ & $136.784,99$ & $-53.165,52$ & $164.293,52$ & $-80.674,05$ \\
\hline 5 & 75 & 1,25 & 2,41 & gérb2 & $-230.836,20$ & $-512.961,70$ & $604.888,43$ & $560.691,39$ & $329.855,20$ & $91.926,70$ & $374.052,24$ & $47.729,66$ \\
\hline 6 & 75 & 1,25 & 3,81 & gérb2 & $-259.517,90$ & $-643.243,60$ & $956.275,90$ & $886.404,23$ & $626.886,30$ & $313.032,25$ & $696.757,97$ & $243.160,59$ \\
\hline 7 & 75 & 1,40 & 1,50 & gérb2 & $-212.193,10$ & $-430.772,00$ & $376.486,57$ & $348.978,04$ & $136.784,99$ & $-54.285,40$ & $164.293,52$ & $-81.793,93$ \\
\hline 8 & 75 & 1,40 & 2,41 & gérb2 & $-230.836,20$ & $-514.761,00$ & $604.888,43$ & $560.691,39$ & $329.855,20$ & $90.127,44$ & $374.052,24$ & $45.930,40$ \\
\hline 9 & 75 & 1,40 & 3,81 & gérb2 & $-259.517,90$ & $-646.088,10$ & $956.275,90$ & $886.404,23$ & $626.886,30$ & $310.187,78$ & $696.757,97$ & $240.316,11$ \\
\hline 10 & 75 & 1,50 & 1,50 & gérb2 & $-212.193,10$ & $-431.518,60$ & $376.486,57$ & $348.978,04$ & $136.784,99$ & $-55.031,98$ & $164.293,52$ & $-82.540,51$ \\
\hline 11 & 75 & 1,50 & 2,41 & gérb2 & $-230.836,20$ & $-515.960,50$ & $604.888,43$ & $560.691,39$ & $329.855,20$ & $88.927,93$ & $374.052,24$ & $44.730,89$ \\
\hline 12 & 75 & 1,50 & 3,81 & gérb2 & $-259.517,90$ & $-647.984,40$ & $956.275,90$ & $886.404,23$ & $626.886,30$ & $308.291,46$ & $696.757,97$ & $238.419,80$ \\
\hline 13 & 80 & 1,10 & 1,50 & gérb2 & $-212.258,90$ & $-419.603,20$ & $376.486,57$ & $348.978,04$ & $136.719,15$ & $-43.116,63$ & $164.227,68$ & $-70.625,16$ \\
\hline 14 & 80 & 1,10 & 2,41 & gérb2 & $-230.902,00$ & $-499.312,80$ & $604.888,43$ & $560.691,39$ & $329.789,37$ & $105.575,63$ & $373.986,40$ & $61.378,59$ \\
\hline 15 & 80 & 1,10 & 3,81 & gérb2 & $-259.583,80$ & $-624.056,20$ & $956.275,90$ & $886.404,23$ & $626.820,47$ & $332.219,71$ & $696.692,13$ & $262.348,05$ \\
\hline 16 & 80 & 1,25 & 1,50 & gérb2 & $-212.258,90$ & $-420.723,10$ & $376.486,57$ & $348.978,04$ & $136.719,15$ & $-44.236,50$ & $164.227,68$ & $-71.745,03$ \\
\hline 17 & 80 & 1,25 & 2,41 & gérb2 & & $-501.112,10$ & $604.888,43$ & $560.691,39$ & $329.789,37$ & $103.776,37$ & $373.986,40$ & $59.579,33$ \\
\hline 18 & 80 & 1,25 & 3,81 & gérb2 & & & 956.2 & & 626.82 & $329.375,24$ & $696.692,13$ & $259.503,57$ \\
\hline 19 & 80 & 1,40 & 1,50 & gér & & & $376.486,57$ & $348.978,04$ & $136.719,15$ & $-45.356,38$ & $164.227,68$ & $-72.864,91$ \\
\hline 20 & 80 & 1,40 & 2,41 & gérb2 & $-230.902,00$ & $-502.911,30$ & $604.888,43$ & $560.691,39$ & $329.789,37$ & $101.977,11$ & $373.986,40$ & $57.780,07$ \\
\hline 21 & 80 & 1,40 & 3,81 & gérb2 & $-259.583,80$ & $-629.745,10$ & $956.275,90$ & $886.404,23$ & $626.820,47$ & $326.530,76$ & $696.692,13$ & $256.659,10$ \\
\hline 22 & 80 & 1,50 & 1,50 & gérb2 & $-212.258,90$ & $-422.589,50$ & $376.486,57$ & $348.978,04$ & $136.719,15$ & $-46.102,96$ & $164.227,68$ & $-73.611,49$ \\
\hline 23 & 80 & 1,50 & 2,41 & gérb2 & $-230.902,00$ & $-504.110,80$ & $604.888,43$ & $560.691,39$ & $329.789,37$ & $100.777,60$ & $373.986,40$ & $56.580,56$ \\
\hline 24 & 80 & 1,50 & 3,81 & gérb2 & $-259.583,80$ & $-631.641,40$ & $956.275,90$ & $886.404,23$ & $626.820,47$ & $324.634,45$ & $696.692,13$ & $254.762,78$ \\
\hline 25 & 100 & 1,10 & 1,50 & gérb2 & $-212.456,40$ & $-392.816,20$ & $376.486,57$ & $348.978,04$ & $136.521,64$ & $-16.329,58$ & $164.030,17$ & $-43.838,11$ \\
\hline 26 & 100 & 1,10 & 2,41 & gérb2 & $-231.099,50$ & $-463.763,80$ & $604.888,43$ & $560.691,39$ & $329.591,86$ & $141.124,64$ & $373.788,90$ & $96.927,61$ \\
\hline 27 & 100 & 1,10 & 3,81 & gérb2 & $-259.781,30$ & $-575.027,20$ & $956.275,90$ & $886.404,23$ & $626.622,96$ & $381.248,67$ & $696.494,62$ & $311.377,00$ \\
\hline 28 & 100 & 1,25 & 1,50 & gérb2 & $-212.456,40$ & $-393.936,00$ & $376.486,57$ & $348.978,04$ & $136.521,64$ & $-17.449,45$ & $164.030,17$ & $-44.957,98$ \\
\hline
\end{tabular}


Tabela 13. Principais resultados obtidos das simulações do quinto cenário logístico para a cadeia como um todo

\begin{tabular}{|c|c|c|c|c|c|c|c|c|c|c|c|c|}
\hline $\begin{array}{l}\text { Simu- } \\
\text { Lação }\end{array}$ & $\begin{array}{l}\text { Núme- } \\
\text { ro de } \\
\text { hastes }\end{array}$ & $\begin{array}{c}\text { Frete } \\
\text { aéreo } \\
\text { (US\$/ } \\
\mathrm{kg} \text { ) }\end{array}$ & $\begin{array}{l}\text { Taxa } \\
\text { câm- } \\
\text { bio } \\
\text { (R\$/ } \\
\text { US\$) }\end{array}$ & $\begin{array}{l}\text { Tipo } \\
\text { de } \\
\text { flor }\end{array}$ & $\begin{array}{l}\text { Custo total } \\
\text { s/ insumo } \\
\text { logístico }\end{array}$ & $\begin{array}{l}\text { Custo total } \\
\mathrm{c} / \text { insumo } \\
\text { logístico }\end{array}$ & $\begin{array}{l}\text { Receita total } \\
\mathrm{s} / \text { produto } \\
\text { logístico }\end{array}$ & $\begin{array}{l}\text { Receita total } \\
\mathrm{c} / \text { produto } \\
\text { logístico }\end{array}$ & $\begin{array}{l}\text { Lucro total } \\
\mathrm{c} / \text { produto } \\
\text { logístico }\end{array}$ & $\begin{array}{l}\text { Lucro total } \\
\mathrm{c} / \text { insumo } \\
\text { logístico }\end{array}$ & $\begin{array}{l}\text { Lucro total } \\
\text { s/ produto } \\
\text { e.insumo } \\
\text { logísticos }\end{array}$ & $\begin{array}{l}\text { Lucro total } \\
\mathrm{c} / \text { insumo } \\
\text { e.produto } \\
\text { logísticos }\end{array}$ \\
\hline 29 & 100 & 1,25 & 2,41 & gérb2 & $-231.099,50$ & $-465.563,00$ & $604.888,43$ & $560.691,39$ & $329.591,86$ & $139.325,38$ & $373.788,90$ & $95.128,35$ \\
\hline 30 & 100 & 1,25 & 3,81 & gérb2 & $-259.781,30$ & $.871,70$ & $956.275,90$ & $6.404,23$ & $6.622,96$ & $8.404,19$ & $696.494,62$ & $308.532,53$ \\
\hline 31 & 100 & 1,40 & 1,50 & gérb2 & $-212.456,40$ & $-395.055,90$ & $376.486,57$ & $348.978,04$ & $136.521,64$ & $-18.569,32$ & $164.030,17$ & $-46.077,85$ \\
\hline 32 & 100 & 1,40 & 2,41 & gérb2 & $-231.099,50$ & $-467.362,30$ & 604.888 & $560.691,39$ & $329.591,86$ & $137.526,12$ & $373.788,90$ & $93.329,09$ \\
\hline 33 & 100 & 1,40 & 3,81 & gérb2 & $-259.781,30$ & $-580.716,20$ & $956.275,90$ & $886.404,23$ & $626.622,96$ & $375.559,72$ & $696.494,62$ & $305.688,05$ \\
\hline 34 & 100 & 1,50 & 1,50 & gérb2 & $-212.456,40$ & $-395.802,50$ & $376.486,57$ & $348.978,04$ & $136.521,64$ & $-19.315,90$ & $164.030,17$ & $-46.824,43$ \\
\hline 35 & 100 & 1,50 & 2,41 & gérb2 & $-231.099,50$ & $-468.561,80$ & $604.888,43$ & $560.691,39$ & $329.591,86$ & $136.326,62$ & $373.788,90$ & $92.129,58$ \\
\hline 36 & 100 & 1,50 & 3,81 & gérb2 & $-259.781,30$ & $-582.612,50$ & $956.275,90$ & $886.404,23$ & $626.622,96$ & $373.663,40$ & $696.494,62$ & $303.791,74$ \\
\hline
\end{tabular}


Tabela 14. Principais resultados obtidos das simulações do primeiro cenário logístico para cada um dos processos

\begin{tabular}{|c|c|c|c|c|c|c|c|c|c|c|c|c|}
\hline \multirow{2}{*}{$\begin{array}{l}\text { Si- } \\
\text { mu- } \\
\text { la- } \\
\text { ção }\end{array}$} & \multirow{2}{*}{$\begin{array}{c}\text { No. } \\
\text { Has- } \\
\text { tes }\end{array}$} & \multirow{2}{*}{$\begin{array}{l}\text { Fre- } \\
\text { te } \\
\text { Aé- } \\
\text { reo }\end{array}$} & \multirow{2}{*}{$\begin{array}{c}\text { Taxa } \\
\text { Câm- } \\
\text { bio }\end{array}$} & \multirow{2}{*}{$\begin{array}{c}\text { Tipo } \\
\text { de } \\
\text { flor }\end{array}$} & \multicolumn{4}{|c|}{$\begin{array}{l}\text { Lucro bruto unitário } \\
\text { por processo }\end{array}$} & \multicolumn{4}{|c|}{$\begin{array}{l}\text { Lucro líquido unitário } \\
\text { por processo }\end{array}$} \\
\hline & & & & & A & B & $\mathrm{C}$ & D & A & B & $\mathrm{C}$ & $\mathrm{D}$ \\
\hline 1 & 75 & 1,10 & 1,50 & lírio & $-0,39$ & 0,04 & $-0,11$ & 0,40 & $-0,39$ & $-0,82$ & $-1,07$ & $-0,61$ \\
\hline 2 & 75 & 1,10 & 2,41 & lírio & $-0,05$ & 0,09 & $-0,18$ & 0,65 & $-0,05$ & $-0,83$ & $-1,24$ & $-0,48$ \\
\hline 3 & 75 & 1,10 & 3,81 & lírio & 0,36 & 0,17 & $-0,29$ & 1,03 & 0,36 & $-0,97$ & $-1,61$ & $-0,40$ \\
\hline 4 & 75 & 1,25 & 1,50 & lírio & $-0,39$ & 0,04 & $-0,12$ & 0,40 & $-0,39$ & $-0,82$ & $-1,07$ & $-0,61$ \\
\hline 5 & 75 & 1,25 & 2,41 & lírio & $-0,05$ & 0,09 & $-0,19$ & 0,65 & $-0,05$ & $-0,83$ & $-1,24$ & $-0,48$ \\
\hline 6 & 75 & 1,25 & 3,81 & lírio & 0,36 & 0,17 & $-0,29$ & 1,03 & 0,36 & $-0,97$ & $-1,61$ & $-0,40$ \\
\hline 7 & 75 & 1,40 & 1,50 & lírio & $-0,39$ & 0,04 & $-0,12$ & 0,40 & $-0,39$ & $-0,82$ & $-1,07$ & $-0,62$ \\
\hline 8 & 75 & 1,40 & 2,41 & lírio & $-0,05$ & 0,09 & $-0,19$ & 0,65 & $-0,05$ & $-0,83$ & $-1,24$ & $-0,49$ \\
\hline 9 & 75 & 1,40 & 3,81 & lírio & 0,36 & 0,17 & $-0,30$ & 1,03 & 0,36 & $-0,97$ & $-1,61$ & $-0,41$ \\
\hline 10 & 75 & 1,50 & 1,50 & lírio & $-0,39$ & 0,04 & $-0,12$ & 0,40 & $-0,39$ & $-0,82$ & $-1,08$ & $-0,62$ \\
\hline 11 & 75 & 1,50 & 2,41 & lírio & $-0,05$ & 0,09 & $-0,19$ & 0,65 & $-0,05$ & $-0,83$ & $-1,24$ & $-0,49$ \\
\hline 12 & 75 & 1,50 & 3,81 & lírio & 0,36 & 0,17 & $-0,30$ & 1,03 & 0,36 & $-0,97$ & $-1,62$ & $-0,41$ \\
\hline 13 & 80 & 1,10 & 1,50 & lírio & $-0,38$ & 0,04 & $-0,11$ & 0,40 & $-0,38$ & $-0,81$ & $-1,06$ & $-0,60$ \\
\hline 14 & 80 & 1,10 & 2,41 & lírio & $-0,04$ & 0,09 & $-0,18$ & 0,65 & $-0,04$ & $-0,82$ & $-1,23$ & $-0,47$ \\
\hline 15 & 80 & 1,10 & 3,81 & lírio & 0,37 & 0,17 & $-0,29$ & 1,03 & 0,37 & $-0,96$ & $-1,60$ & $-0,38$ \\
\hline 16 & 80 & 1,25 & 1,50 & lírio & $-0,38$ & 0,04 & $-0,12$ & 0,40 & $-0,38$ & $-0,81$ & $-1,06$ & $-0,60$ \\
\hline 17 & 80 & 1,25 & 2,41 & lírio & $-0,04$ & 0,09 & $-0,19$ & 0,65 & $-0,04$ & $-0,82$ & $-1,23$ & $-0,47$ \\
\hline 18 & 80 & 1,25 & 3,81 & lírio & 0,37 & 0,17 & $-0,29$ & 1,03 & 0,37 & $-0,96$ & $-1,60$ & $-0,39$ \\
\hline 19 & 80 & 1,40 & 1,50 & lírio & $-0,38$ & 0,04 & $-0,12$ & 0,40 & $-0,38$ & $-0,81$ & $-1,06$ & $-0,60$ \\
\hline 20 & 80 & 1,40 & 2,41 & lírio & $-0,04$ & 0,09 & $-0,19$ & 0,65 & $-0,04$ & $-0,82$ & $-1,23$ & $-0,47$ \\
\hline 21 & 80 & 1,40 & 3,81 & lírio & 0,37 & 0,17 & $-0,30$ & 1,03 & 0,37 & $-0,96$ & $-1,60$ & $-0,39$ \\
\hline 22 & 80 & 1,50 & 1,50 & lírio & $-0,38$ & 0,04 & $-0,12$ & 0,40 & $-0,38$ & $-0,81$ & $-1,07$ & $-0,61$ \\
\hline 23 & 80 & 1,50 & 2,41 & lírio & $-0,04$ & 0,09 & $-0,19$ & 0,65 & $-0,04$ & $-0,82$ & $-1,23$ & $-0,48$ \\
\hline 24 & 80 & 1,50 & 3,81 & lírio & 0,37 & 0,17 & $-0,30$ & 1,03 & 0,37 & $-0,96$ & $-1,61$ & $-0,40$ \\
\hline 25 & 100 & 1,10 & 1,50 & lírio & $-0,35$ & 0,04 & $-0,11$ & 0,41 & $-0,35$ & $-0,78$ & $-1,03$ & $-0,57$ \\
\hline 26 & 100 & 1,10 & 2,41 & lírio & $-0,01$ & 0,09 & $-0,18$ & 0,66 & $-0,01$ & $-0,80$ & $-1,20$ & $-0,43$ \\
\hline 27 & 100 & 1,10 & 3,81 & lírio & 0,40 & 0,17 & $-0,29$ & 1,04 & 0,40 & $-0,93$ & $-1,56$ & $-0,34$ \\
\hline 28 & 100 & 1,25 & 1,50 & lírio & $-0,35$ & 0,04 & $-0,12$ & 0,41 & $-0,35$ & $-0,78$ & $-1,03$ & $-0,57$ \\
\hline 29 & 100 & 1,25 & 2,41 & lírio & $-0,01$ & 0,09 & $-0,18$ & 0,66 & $-0,01$ & $-0,80$ & $-1,20$ & $-0,43$ \\
\hline 30 & 100 & 1,25 & 3,81 & lírio & 0,40 & 0,17 & $-0,29$ & 1,04 & 0,40 & $-0,93$ & $-1,57$ & $-0,35$ \\
\hline 31 & 100 & 1,40 & 1,50 & lírio & $-0,35$ & 0,04 & $-0,12$ & 0,41 & $-0,35$ & $-0,78$ & $-1,03$ & $-0,57$ \\
\hline 32 & 100 & 1,40 & 2,41 & lírio & $-0,01$ & 0,09 & $-0,19$ & 0,66 & $-0,01$ & $-0,80$ & $-1,20$ & $-0,44$ \\
\hline 33 & 100 & 1,40 & 3,81 & lírio & 0,40 & 0,17 & $-0,30$ & 1,04 & 0,40 & $-0,93$ & $-1,57$ & $-0,35$ \\
\hline 34 & 100 & 1,50 & 1,50 & lírio & $-0,35$ & 0,04 & $-0,12$ & 0,41 & $-0,35$ & $-0,78$ & $-1,04$ & $-0,57$ \\
\hline 35 & 100 & 1,50 & 2,41 & lírio & $-0,01$ & 0,09 & $-0,19$ & 0,66 & $-0,01$ & $-0,80$ & $-1,20$ & $-0,44$ \\
\hline 36 & 100 & 1,50 & 3,81 & lírio & 0,40 & 0,17 & $-0,30$ & 1,04 & 0,40 & $-0,93$ & $-1,57$ & $-0,35$ \\
\hline 1 & 75 & 1,10 & 1,50 & gérb1 & $-0,36$ & $-0,17$ & $-0,09$ & 0,19 & $-0,36$ & $-0,83$ & $-0,94$ & $-0,73$ \\
\hline 2 & 75 & 1,10 & 2,41 & gérb1 & $-0,17$ & $-0,14$ & $-0,14$ & 0,32 & $-0,17$ & $-0,83$ & $-1,03$ & $-0,67$ \\
\hline 3 & 75 & 1,10 & 3,81 & gérb1 & 0,12 & $-0,11$ & $-0,22$ & 0,51 & 0,12 & $-0,83$ & $-1,18$ & $-0,59$ \\
\hline 4 & 75 & 1,25 & 1,50 & gérb1 & $-0,36$ & $-0,17$ & $-0,09$ & 0,19 & $-0,36$ & $-0,83$ & $-0,94$ & $-0,73$ \\
\hline 5 & 75 & 1,25 & 2,41 & gérb1 & $-0,17$ & $-0,14$ & $-0,14$ & 0,32 & $-0,17$ & $-0,83$ & $-1,04$ & $-0,68$ \\
\hline
\end{tabular}


Tabela 14. Principais resultados obtidos das simulações do primeiro cenário logístico para cada um dos processos

\begin{tabular}{|c|c|c|c|c|c|c|c|c|c|c|c|c|}
\hline \multirow{2}{*}{$\begin{array}{l}\text { Si- } \\
\text { mu- } \\
\text { la- } \\
\text { ção }\end{array}$} & \multirow{2}{*}{$\begin{array}{c}\text { No. } \\
\text { Has- } \\
\text { tes }\end{array}$} & \multirow{2}{*}{$\begin{array}{c}\text { Fre- } \\
\text { te } \\
\text { Aé- } \\
\text { reo }\end{array}$} & \multirow{2}{*}{$\begin{array}{c}\text { Taxa } \\
\text { Câm- } \\
\text { bio }\end{array}$} & \multirow{2}{*}{$\begin{array}{c}\text { Tipo } \\
\text { de } \\
\text { flor }\end{array}$} & \multicolumn{4}{|c|}{$\begin{array}{l}\text { Lucro bruto unitário } \\
\text { por processo }\end{array}$} & \multicolumn{4}{|c|}{$\begin{array}{c}\text { Lucro líquido unitário } \\
\text { por processo }\end{array}$} \\
\hline & & & & & A & B & $\mathrm{C}$ & D & A & B & $\mathrm{C}$ & $\mathrm{D}$ \\
\hline 6 & 75 & 1,25 & 3,81 & gérb1 & 0,12 & $-0,11$ & $-0,22$ & 0,51 & 0,12 & $-0,83$ & $-1,19$ & $-0,60$ \\
\hline 7 & 75 & 1,40 & 1,50 & gérb1 & $-0,36$ & $-0,17$ & $-0,09$ & 0,19 & $-0,36$ & $-0,83$ & $-0,94$ & $-0,74$ \\
\hline 8 & 75 & 1,40 & 2,41 & gérb1 & $-0,17$ & $-0,14$ & $-0,14$ & 0,32 & $-0,17$ & $-0,83$ & $-1,04$ & $-0,68$ \\
\hline 9 & 75 & 1,40 & 3,81 & gérb1 & 0,12 & $-0,11$ & $-0,23$ & 0,51 & 0,12 & $-0,83$ & $-1,19$ & $-0,60$ \\
\hline 10 & 75 & 1,50 & 1,50 & gérb1 & $-0,36$ & $-0,17$ & $-0,09$ & 0,19 & $-0,36$ & $-0,83$ & $-0,94$ & $-0,74$ \\
\hline 11 & 75 & 1,50 & 2,41 & gérb1 & $-0,17$ & $-0,14$ & $-0,15$ & 0,32 & $-0,17$ & $-0,83$ & $-1,04$ & $-0,68$ \\
\hline 12 & 75 & 1,50 & 3,81 & gérb1 & 0,12 & $-0,11$ & $-0,23$ & 0,51 & 0,12 & $-0,83$ & $-1,19$ & $-0,60$ \\
\hline 13 & 80 & 1,10 & 1,50 & gérb1 & $-0,35$ & $-0,17$ & $-0,09$ & 0,19 & $-0,35$ & $-0,83$ & $-0,93$ & $-0,73$ \\
\hline 14 & 80 & 1,10 & 2,41 & gérb1 & $-0,16$ & $-0,14$ & $-0,14$ & 0,32 & $-0,16$ & $-0,83$ & $-1,03$ & $-0,67$ \\
\hline 15 & 80 & 1,10 & 3,81 & gérb1 & 0,12 & $-0,11$ & $-0,22$ & 0,51 & 0,12 & $-0,83$ & $-1,18$ & $-0,58$ \\
\hline 16 & 80 & 1,25 & 1,50 & gérb1 & $-0,35$ & $-0,17$ & $-0,09$ & 0,19 & $-0,35$ & $-0,83$ & $-0,94$ & $-0,73$ \\
\hline 17 & 80 & 1,25 & 2,41 & gérb1 & $-0,16$ & $-0,14$ & $-0,14$ & 0,32 & $-0,16$ & $-0,83$ & $-1,03$ & $-0,67$ \\
\hline 18 & 80 & 1,25 & 3,81 & gérb1 & 0,12 & $-0,11$ & $-0,22$ & 0,51 & 0,12 & $-0,83$ & $-1,18$ & $-0,59$ \\
\hline 19 & 80 & 1,40 & 1,50 & gérb1 & $-0,35$ & $-0,17$ & $-0,09$ & 0,19 & $-0,35$ & $-0,83$ & $-0,94$ & $-0,73$ \\
\hline 20 & 80 & 1,40 & 2,41 & gérb1 & $-0,16$ & $-0,14$ & $-0,14$ & 0,32 & $-0,16$ & $-0,83$ & $-1,03$ & $-0,67$ \\
\hline 21 & 80 & 1,40 & 3,81 & gérb1 & 0,12 & $-0,11$ & $-0,23$ & 0,51 & 0,12 & $-0,83$ & $-1,18$ & $-0,59$ \\
\hline 22 & 80 & 1,50 & 1,50 & gérb1 & $-0,35$ & $-0,17$ & $-0,09$ & 0,19 & $-0,35$ & $-0,83$ & $-0,94$ & $-0,73$ \\
\hline 23 & 80 & 1,50 & 2,41 & gérb1 & $-0,16$ & $-0,14$ & $-0,15$ & 0,32 & $-0,16$ & $-0,83$ & $-1,03$ & $-0,67$ \\
\hline 24 & 80 & 1,50 & 3,81 & gérb1 & 0,12 & $-0,11$ & $-0,23$ & 0,51 & 0,12 & $-0,83$ & $-1,19$ & $-0,59$ \\
\hline 25 & 100 & 1,10 & 1,50 & gérb1 & $-0,34$ & $-0,17$ & $-0,09$ & 0,19 & $-0,34$ & $-0,81$ & $-0,92$ & $-0,71$ \\
\hline 26 & 100 & 1,10 & 2,41 & gérb1 & $-0,15$ & $-0,14$ & $-0,14$ & 0,32 & $-0,15$ & $-0,81$ & $-1,01$ & $-0,64$ \\
\hline 27 & 100 & 1,10 & 3,81 & gérb1 & 0,14 & $-0,11$ & $-0,22$ & 0,52 & 0,14 & $-0,81$ & $-1,16$ & $-0,56$ \\
\hline 28 & 100 & 1,25 & 1,50 & gérb1 & $-0,34$ & $-0,17$ & $-0,09$ & 0,19 & $-0,34$ & $-0,81$ & $-0,92$ & $-0,71$ \\
\hline 29 & 100 & 1,25 & 2,41 & gérb1 & $-0,15$ & $-0,14$ & $-0,14$ & 0,32 & $-0,15$ & $-0,81$ & $-1,01$ & $-0,65$ \\
\hline 30 & 100 & 1,25 & 3,81 & gérb1 & 0,14 & $-0,11$ & $-0,22$ & 0,52 & 0,14 & $-0,81$ & $-1,16$ & $-0,56$ \\
\hline 31 & 100 & 1,40 & 1,50 & gérb1 & $-0,34$ & $-0,17$ & $-0,09$ & 0,19 & $-0,34$ & $-0,81$ & $-0,92$ & $-0,71$ \\
\hline 32 & 100 & 1,40 & 2,41 & gérb1 & $-0,15$ & $-0,14$ & $-0,14$ & 0,32 & $-0,15$ & $-0,81$ & $-1,02$ & $-0,65$ \\
\hline 33 & 100 & 1,40 & 3,81 & gérb1 & 0,14 & $-0,11$ & $-0,22$ & 0,52 & 0,14 & $-0,81$ & $-1,17$ & $-0,56$ \\
\hline 34 & 100 & 1,50 & 1,50 & gérb1 & $-0,34$ & $-0,17$ & $-0,09$ & 0,19 & $-0,34$ & $-0,81$ & $-0,92$ & $-0,71$ \\
\hline 35 & 100 & 1,50 & 2,41 & gérb1 & $-0,15$ & $-0,14$ & $-0,14$ & 0,32 & $-0,15$ & $-0,81$ & $-1,02$ & $-0,65$ \\
\hline 36 & 100 & 1,50 & 3,81 & gérb1 & 0,14 & $-0,11$ & $-0,23$ & 0,52 & 0,14 & $-0,81$ & $-1,17$ & $-0,57$ \\
\hline 1 & 75 & 1,10 & 1,50 & gérb2 & $-0,06$ & $-0,03$ & $-0,06$ & 0,15 & $-0,06$ & $-0,19$ & $-0,29$ & $-0,12$ \\
\hline 2 & 75 & 1,10 & 2,41 & gérb2 & 0,09 & 0,00 & $-0,10$ & 0,24 & 0,09 & $-0,18$ & $-0,35$ & $-0,06$ \\
\hline 3 & 75 & 1,10 & 3,81 & gérb2 & 0,33 & 0,03 & $-0,15$ & 0,38 & 0,33 & $-0,15$ & $-0,43$ & 0,02 \\
\hline 4 & 75 & 1,25 & 1,50 & gérb2 & $-0,06$ & $-0,03$ & $-0,06$ & 0,15 & $-0,06$ & $-0,19$ & $-0,29$ & $-0,12$ \\
\hline 5 & 75 & 1,25 & 2,41 & gérb2 & 0,09 & 0,00 & $-0,10$ & 0,24 & 0,09 & $-0,18$ & $-0,35$ & $-0,06$ \\
\hline 6 & 75 & 1,25 & 3,81 & gérb2 & 0,33 & 0,03 & $-0,16$ & 0,38 & 0,33 & $-0,15$ & $-0,44$ & 0,02 \\
\hline 7 & 75 & 1,40 & 1,50 & gérb2 & $-0,06$ & $-0,03$ & $-0,06$ & 0,15 & $-0,06$ & $-0,19$ & $-0,29$ & $-0,12$ \\
\hline 8 & 75 & 1,40 & 2,41 & gérb2 & 0,09 & 0,00 & $-0,10$ & 0,24 & 0,09 & $-0,18$ & $-0,35$ & $-0,07$ \\
\hline 9 & 75 & 1,40 & 3,81 & gérb2 & 0,33 & 0,03 & $-0,16$ & 0,38 & 0,33 & $-0,15$ & $-0,44$ & 0,02 \\
\hline
\end{tabular}


Tabela 14. Principais resultados obtidos das simulações do primeiro cenário logístico para cada um dos processos

\begin{tabular}{|c|c|c|c|c|c|c|c|c|c|c|c|c|}
\hline \multirow{2}{*}{$\begin{array}{c}\text { Si- } \\
\text { mu- } \\
\text { la- } \\
\text { ção }\end{array}$} & \multirow{2}{*}{$\begin{array}{c}\text { No. } \\
\text { Has- } \\
\text { tes }\end{array}$} & \multirow{2}{*}{$\begin{array}{c}\text { Fre- } \\
\text { te } \\
\text { Aé- } \\
\text { reo }\end{array}$} & \multirow{2}{*}{$\begin{array}{c}\text { Taxa } \\
\text { Câm- } \\
\text { bio } \\
\end{array}$} & \multirow{2}{*}{$\begin{array}{c}\text { Tipo } \\
\text { de } \\
\text { flor }\end{array}$} & \multicolumn{4}{|c|}{$\begin{array}{l}\text { Lucro bruto unitário } \\
\text { por processo }\end{array}$} & \multicolumn{4}{|c|}{$\begin{array}{c}\text { Lucro líquido unitário } \\
\text { por processo }\end{array}$} \\
\hline & & & & & A & B & $\mathrm{C}$ & D & A & B & C & D \\
\hline 10 & 75 & 1,50 & 1,50 & gérb2 & $-0,06$ & $-0,03$ & $-0,06$ & 0,15 & $-0,06$ & $-0,19$ & $-0,29$ & $-0,12$ \\
\hline 11 & 75 & 1,50 & 2,41 & gérb2 & 0,09 & 0,00 & $-0,10$ & 0,24 & 0,09 & $-0,18$ & $-0,35$ & $-0,07$ \\
\hline 12 & 75 & 1,50 & 3,81 & gérb2 & 0,33 & 0,03 & $-0,16$ & 0,38 & 0,33 & $-0,15$ & $-0,44$ & 0,01 \\
\hline 13 & 80 & 1,10 & 1,50 & gérb2 & $-0,06$ & $-0,03$ & $-0,06$ & 0,15 & $-0,06$ & $-0,18$ & $-0,28$ & $-0,11$ \\
\hline 14 & 80 & 1,10 & 2,41 & gérb2 & 0,10 & 0,00 & $-0,10$ & 0,24 & 0,10 & $-0,17$ & $-0,34$ & $-0,05$ \\
\hline 15 & 80 & 1,10 & 3,81 & gérb2 & 0,33 & 0,03 & $-0,15$ & 0,38 & 0,33 & $-0,15$ & $-0,43$ & 0,03 \\
\hline 16 & 80 & 1,25 & 1,50 & gérb2 & $-0,06$ & $-0,03$ & $-0,06$ & 0,15 & $-0,06$ & $-0,18$ & $-0,29$ & $-0,11$ \\
\hline 17 & 80 & 1,25 & 2,41 & gérb2 & 0,10 & 0,00 & $-0,10$ & 0,24 & 0,10 & $-0,17$ & $-0,34$ & $-0,05$ \\
\hline 18 & 80 & 1,25 & 3,81 & gérb2 & 0,33 & 0,03 & $-0,16$ & 0 , & 0,33 & $-0,15$ & $-0,43$ & 0,03 \\
\hline 19 & 80 & 1,40 & 1,50 & gérb2 & $-0,06$ & $-0,03$ & $-0,06$ & 0,15 & $-0,06$ & $-0,18$ & $-0,29$ & $-0,11$ \\
\hline 20 & 80 & 1,40 & 2,41 & gérb2 & 0,10 & 0,00 & $-0,10$ & 0,24 & 0,10 & $-0,17$ & $-0,34$ & $-0,06$ \\
\hline 21 & 80 & 1,40 & 3,81 & gérb2 & 0,33 & 0,03 & $-0,1$ & 0,3 & 0,33 & $-0,15$ & $-0,43$ & 0,03 \\
\hline 22 & 80 & 1,50 & 1,50 & gérb2 & $-0,06$ & $-0,03$ & $-0,06$ & 0,15 & $-0,06$ & $-0,18$ & $-0,29$ & $-0,11$ \\
\hline 23 & 80 & 1,50 & 2,41 & gérb2 & 0,10 & 0,00 & $-0,10$ & 0,24 & 0,10 & $-0,17$ & $-0,35$ & $-0,06$ \\
\hline 24 & 80 & 1,50 & 3,81 & gérb2 & 0,33 & 0,03 & $-0,16$ & 0,38 & 0,33 & $-0,15$ & $-0,44$ & 0,02 \\
\hline 25 & 100 & 1,10 & 1,50 & gérb2 & $-0,04$ & $-0,03$ & $-0,06$ & 0,15 & $-0,04$ & $-0,17$ & $-0,27$ & $-0,09$ \\
\hline 26 & 100 & 1,10 & 2,41 & gérb2 & 0,11 & 0,00 & $-0,09$ & 0,25 & 0,11 & $-0,15$ & $-0,32$ & $-0,03$ \\
\hline 27 & 100 & 1,10 & 3,81 & gérb2 & 0,35 & 0,03 & $-0,15$ & 0,39 & 0,35 & $-0,13$ & $-0,41$ & 0,06 \\
\hline 28 & 100 & 1,25 & 1,50 & gérb2 & $-0,04$ & $-0,03$ & $-0,06$ & 0,15 & $-0,04$ & $-0,17$ & $-0,27$ & $-0,09$ \\
\hline 29 & 100 & 1,25 & 2,41 & gérb2 & 0,11 & 0,00 & $-0,10$ & 0,25 & 0,11 & $-0,15$ & $-0,33$ & $-0,03$ \\
\hline 30 & 100 & 1,25 & 3,81 & gérb2 & 0,35 & 0,03 & $-0,15$ & 0,39 & 0,35 & $-0,13$ & $-0,41$ & 0,06 \\
\hline 31 & 100 & 1,40 & 1,50 & gérb2 & $-0,04$ & $-0,03$ & $-0,06$ & 0,15 & $-0,04$ & $-0,17$ & $-0,27$ & $-0,09$ \\
\hline 32 & 100 & 1,40 & 2,41 & gérb2 & 0,11 & 0,00 & $-0,10$ & 0,25 & 0,11 & $-0,15$ & $-0,33$ & $-0,03$ \\
\hline 33 & 100 & 1,40 & 3,81 & gérb2 & 0,35 & 0,03 & $-0,16$ & 0,39 & 0,35 & $-0,13$ & $-0,42$ & 0,05 \\
\hline 34 & 100 & 1,50 & 1,50 & gérb2 & $-0,04$ & $-0,03$ & $-0,06$ & 0,15 & $-0,04$ & $-0,17$ & $-0,27$ & $-0,09$ \\
\hline 35 & 100 & 1,50 & 2,41 & gérb2 & 0,11 & 0,00 & $-0,10$ & 0,25 & 0,11 & $-0,15$ & $-0,33$ & $-0,04$ \\
\hline 36 & 100 & 1,50 & 3,81 & gérb2 & 0,35 & 0,03 & $-0,16$ & 0,39 & 0,35 & $-0,13$ & $-0,42$ & 0,05 \\
\hline
\end{tabular}


Tabela 15. Principais resultados obtidos das simulações do segundo cenário logístico para cada um dos processos

\begin{tabular}{|c|c|c|c|c|c|c|c|c|c|c|c|c|}
\hline \multirow{2}{*}{$\begin{array}{c}\text { Si- } \\
\text { mu- } \\
\text { la- } \\
\text { ção }\end{array}$} & \multirow{2}{*}{$\begin{array}{c}\text { No. } \\
\text { Has- } \\
\text { tes }\end{array}$} & \multirow{2}{*}{$\begin{array}{c}\text { Fre- } \\
\text { te } \\
\text { Aé- } \\
\text { reo }\end{array}$} & \multirow{2}{*}{$\begin{array}{c}\text { Taxa } \\
\text { Câm } \\
\text {-bio }\end{array}$} & \multirow{2}{*}{$\begin{array}{c}\text { Tipo } \\
\text { de } \\
\text { flor }\end{array}$} & \multicolumn{4}{|c|}{$\begin{array}{c}\text { Lucro bruto unitário } \\
\text { por processo }\end{array}$} & \multicolumn{4}{|c|}{$\begin{array}{c}\text { Lucro líquido unitário } \\
\text { por processo }\end{array}$} \\
\hline & & & & & A & B & $\mathrm{C}$ & $\mathrm{D}$ & A & B & $\mathrm{C}$ & $\mathrm{D}$ \\
\hline 1 & 75 & 1,10 & 1,50 & lírio & $-0,35$ & 0,04 & $-0,11$ & 0,40 & $-0,35$ & $-0,78$ & $-1,04$ & $-0,58$ \\
\hline 2 & 75 & 1,10 & 2,41 & lírio & $-0,01$ & 0,09 & $-0,18$ & 0,65 & $-0,01$ & $-0,80$ & $-1,20$ & $-0,44$ \\
\hline 3 & 75 & 1,10 & 3,81 & lírio & 0,41 & 0,17 & $-0,29$ & 1,03 & 0,41 & $-0,92$ & $-1,56$ & $-0,35$ \\
\hline 4 & 75 & 1,25 & 1,50 & lírio & $-0,35$ & 0,04 & $-0,12$ & 0,40 & $-0,35$ & $-0,78$ & $-1,04$ & $-0,58$ \\
\hline 5 & 75 & 1,25 & 2,41 & lírio & $-0,01$ & 0,09 & $-0,19$ & 0,65 & $-0,01$ & $-0,80$ & $-1,20$ & $-0,44$ \\
\hline 6 & 75 & 1,25 & 3,81 & lírio & 0,41 & 0,17 & $-0,29$ & 1,03 & 0,41 & $-0,92$ & $-1,56$ & $-0,35$ \\
\hline 7 & 75 & 1,40 & 1,50 & lírio & $-0,35$ & 0,04 & $-0,12$ & 0,40 & $-0,35$ & $-0,78$ & $-1,04$ & $-0,58$ \\
\hline 8 & 75 & 1,40 & 2,41 & lírio & $-0,01$ & 0,09 & $-0,19$ & 0,65 & $-0,01$ & $-0,80$ & $-1,20$ & $-0,45$ \\
\hline 9 & 75 & 1,40 & 3,81 & lírio & 0,41 & 0,17 & $-0,30$ & 1,03 & 0,41 & $-0,92$ & $-1,56$ & $-0,36$ \\
\hline 10 & 75 & 1,50 & 1,50 & lírio & $-0,35$ & 0,04 & $-0,12$ & 0,40 & $-0,35$ & $-0,78$ & $-1,04$ & $-0,58$ \\
\hline 11 & 75 & 1,50 & 2,41 & lírio & $-0,01$ & 0,09 & $-0,19$ & 0,65 & $-0,01$ & $-0,80$ & $-1,21$ & $-0,45$ \\
\hline 12 & 75 & 1,50 & 3,81 & lírio & 0,41 & 0,17 & $-0,30$ & 1,03 & 0,41 & $-0,92$ & $-1,57$ & $-0,36$ \\
\hline 13 & 80 & 1,10 & 1,50 & lírio & $-0,34$ & 0,04 & $-0,11$ & 0,40 & $-0,34$ & $-0,78$ & $-1,03$ & $-0,56$ \\
\hline 14 & 80 & 1,10 & 2,41 & lírio & 0,00 & 0,09 & $-0,18$ & 0,65 & 0,00 & $-0,79$ & $-1,19$ & $-0,43$ \\
\hline 15 & 80 & 1,10 & 3,81 & lírio & 0,42 & 0,17 & $-0,29$ & 1,03 & 0,42 & $-0,91$ & $-1,55$ & $-0,33$ \\
\hline 16 & 80 & 1,25 & 1,50 & lírio & $-0,34$ & 0,04 & $-0,12$ & 0,40 & $-0,34$ & $-0,78$ & $-1,03$ & $-0,57$ \\
\hline 17 & 80 & 1,25 & 2,41 & lírio & 0,00 & 0,09 & $-0,19$ & 0,65 & 0,00 & $-0,79$ & $-1,19$ & $-0,43$ \\
\hline 18 & 80 & 1,25 & 3,81 & lírio & 0,42 & 0,17 & $-0,29$ & 1,03 & 0,42 & $-0,91$ & $-1,55$ & $-0,34$ \\
\hline 19 & 80 & 1,40 & 1,50 & lírio & $-0,34$ & 0,04 & $-0,12$ & 0,40 & $-0,34$ & $-0,78$ & $-1,03$ & $-0,57$ \\
\hline 20 & 80 & 1,40 & 2,41 & lírio & 0,00 & 0,09 & $-0,19$ & 0,65 & 0,00 & $-0,79$ & $-1,19$ & $-0,43$ \\
\hline 21 & 80 & 1,40 & 3,81 & lírio & 0,42 & 0,17 & $-0,30$ & 1,03 & 0,42 & $-0,91$ & $-1,55$ & $-0,34$ \\
\hline 22 & 80 & 1,50 & 1,50 & lírio & $-0,34$ & 0,04 & $-0,12$ & 0,40 & $-0,34$ & $-0,78$ & $-1,03$ & $-0,57$ \\
\hline 23 & 80 & 1,50 & 2,41 & lírio & 0,00 & 0,09 & $-0,19$ & 0,65 & 0,00 & $-0,79$ & $-1,20$ & $-0,44$ \\
\hline 24 & 80 & 1,50 & 3,81 & lírio & 0,42 & 0,17 & $-0,30$ & 1,03 & 0,42 & $-0,91$ & $-1,56$ & $-0,34$ \\
\hline 25 & 100 & 1,10 & 1,50 & lírio & $-0,31$ & 0,04 & $-0,11$ & 0,41 & $-0,31$ & $-0,75$ & $-1,00$ & $-0,53$ \\
\hline 26 & 100 & 1,10 & 2,41 & lírio & 0,03 & 0,09 & $-0,18$ & 0,66 & 0,03 & $-0,76$ & $-1,16$ & $-0,39$ \\
\hline 27 & 100 & 1,10 & 3,81 & lírio & 0,45 & 0,17 & $-0,29$ & 1,04 & 0,45 & $-0,88$ & $-1,51$ & $-0,29$ \\
\hline 28 & 100 & 1,25 & 1,50 & lírio & $-0,31$ & 0,04 & $-0,11$ & 0,41 & $-0,31$ & $-0,75$ & $-1,00$ & $-0,53$ \\
\hline 29 & 100 & 1,25 & 2,41 & lírio & 0,03 & 0,09 & $-0,18$ & 0,66 & 0,03 & $-0,76$ & $-1,16$ & $-0,39$ \\
\hline 30 & 100 & 1,25 & 3,81 & lírio & 0,45 & 0,17 & $-0,29$ & 1,04 & 0,45 & $-0,88$ & $-1,52$ & $-0,30$ \\
\hline 31 & 100 & 1,40 & 1,50 & lírio & $-0,31$ & 0,04 & $-0,12$ & 0,41 & $-0,31$ & $-0,75$ & $-1,00$ & $-0,53$ \\
\hline 32 & 100 & 1,40 & 2,41 & lírio & 0,03 & 0,09 & $-0,19$ & 0,66 & 0,03 & $-0,76$ & $-1,16$ & $-0,40$ \\
\hline 33 & 100 & 1,40 & 3,81 & lírio & 0,45 & 0,17 & $-0,29$ & 1,04 & 0,45 & $-0,88$ & $-1,52$ & $-0,30$ \\
\hline 34 & 100 & 1,50 & 1,50 & lírio & $-0,31$ & 0,04 & $-0,12$ & 0,41 & $-0,31$ & $-0,75$ & $-1,00$ & $-0,53$ \\
\hline 35 & 100 & 1,50 & 2,41 & lírio & 0,03 & 0,09 & $-0,19$ & 0,66 & 0,03 & $-0,76$ & $-1,16$ & $-0,40$ \\
\hline 36 & 100 & 1,50 & 3,81 & lírio & 0,45 & 0,17 & $-0,30$ & 1,04 & 0,45 & $-0,88$ & $-1,52$ & $-0,30$ \\
\hline 1 & 75 & 1,10 & 1,50 & gérb1 & $-0,33$ & $-0,16$ & $-0,09$ & 0,19 & $-0,33$ & $-0,79$ & $-0,90$ & $-0,69$ \\
\hline 2 & 75 & 1,10 & 2,41 & gérb1 & $-0,14$ & $-0,13$ & $-0,14$ & 0,32 & $-0,14$ & $-0,79$ & $-1,00$ & $-0,63$ \\
\hline 3 & 75 & 1,10 & 3,81 & gérb1 & 0,15 & $-0,10$ & $-0,22$ & 0,51 & 0,15 & $-0,79$ & $-1,14$ & $-0,55$ \\
\hline 4 & 75 & 1,25 & 1,50 & gérb1 & $-0,33$ & $-0,16$ & $-0,09$ & 0,19 & $-0,33$ & $-0,79$ & $-0,90$ & $-0,70$ \\
\hline
\end{tabular}


Tabela 15. Principais resultados obtidos das simulações do segundo cenário logístico para cada um dos processos

\begin{tabular}{|c|c|c|c|c|c|c|c|c|c|c|c|c|}
\hline \multirow{2}{*}{$\begin{array}{c}\text { Si- } \\
\text { mu- } \\
\text { la- } \\
\text { ção }\end{array}$} & \multirow{2}{*}{$\begin{array}{c}\text { No. } \\
\text { Has- } \\
\text { tes }\end{array}$} & \multirow{2}{*}{$\begin{array}{l}\text { Fre- } \\
\text { te } \\
\text { Aé- } \\
\text { reo } \\
\end{array}$} & \multirow{2}{*}{$\begin{array}{l}\text { Taxa } \\
\text { Câm } \\
\text {-bio }\end{array}$} & \multirow{2}{*}{$\begin{array}{c}\text { Tipo } \\
\text { de } \\
\text { flor }\end{array}$} & \multicolumn{4}{|c|}{$\begin{array}{c}\text { Lucro bruto unitário } \\
\text { por processo }\end{array}$} & \multicolumn{4}{|c|}{$\begin{array}{c}\text { Lucro líquido unitário } \\
\text { por processo }\end{array}$} \\
\hline & & & & & A & B & $\mathrm{C}$ & D & A & B & $\mathrm{C}$ & D \\
\hline 5 & 75 & 1,25 & 2,41 & gérb1 & $-0,14$ & $-0,13$ & $-0,14$ & 0,32 & $-0,14$ & $-0,79$ & $-1,00$ & $-0,64$ \\
\hline 6 & 75 & 1,25 & 3,81 & gérb1 & 0,15 & $-0,10$ & $-0,22$ & 0,51 & 0,15 & $-0,79$ & $-1,15$ & $-0,55$ \\
\hline 7 & 75 & 1,40 & 1,50 & gérb1 & $-0,33$ & $-0,16$ & $-0,09$ & 0,19 & $-0,33$ & $-0,79$ & $-0,91$ & $-0,70$ \\
\hline 8 & 75 & 1,40 & 2,41 & gérb1 & $-0,14$ & $-0,13$ & $-0,14$ & 0,32 & $-0,14$ & $-0,79$ & $-1,00$ & $-0,64$ \\
\hline 9 & 75 & 1,40 & 3,81 & gérb1 & 0,15 & $-0,10$ & $-0,22$ & 0,51 & 0,15 & $-0,79$ & $-1,15$ & $-0,56$ \\
\hline 10 & 75 & 1,50 & 1,50 & gérb1 & $-0,33$ & $-0,16$ & $-0,09$ & 0,19 & $-0,33$ & $-0,79$ & $-0,91$ & $-0,70$ \\
\hline 11 & 75 & 1,50 & 2,41 & gérb1 & $-0,14$ & $-0,13$ & $-0,14$ & 0,32 & $-0,14$ & $-0,79$ & $-1,00$ & $-0,64$ \\
\hline 12 & 75 & 1,50 & 3,81 & gérb1 & 0,15 & $-0,10$ & $-0,23$ & 0,51 & 0,15 & $-0,79$ & $-1,15$ & $-0,56$ \\
\hline 13 & 80 & 1,10 & 1,50 & gérb1 & $-0,32$ & $-0,16$ & $-0,09$ & 0,19 & $-0,32$ & $-0,79$ & $-0,90$ & $-0,69$ \\
\hline 14 & 80 & 1,10 & 2,41 & gérb1 & $-0,13$ & $-0,13$ & $-0,14$ & 0,32 & $-0,13$ & $-0,79$ & $-0,99$ & $-0,63$ \\
\hline 15 & 80 & 1,10 & 3,81 & gérb1 & 0,15 & $-0,10$ & $-0,22$ & 0,51 & 0,15 & $-0,79$ & $-1,14$ & $-0,54$ \\
\hline 16 & 80 & 1,25 & 1,50 & gérb1 & $-0,32$ & $-0,16$ & $-0,09$ & 0,19 & $-0,32$ & $-0,79$ & $-0,90$ & $-0,69$ \\
\hline 17 & 80 & 1,25 & 2,41 & gérb1 & $-0,13$ & $-0,13$ & $-0,14$ & 0,32 & $-0,13$ & $-0,79$ & $-0,99$ & $-0,63$ \\
\hline 18 & 80 & 1,25 & 3,81 & gérb1 & 0,15 & $-0,10$ & $-0,22$ & 0,51 & 0,15 & $-0,79$ & $-1,14$ & $-0,54$ \\
\hline 19 & 80 & 1,40 & 1,50 & gérb1 & $-0,32$ & $-0,16$ & $-0,09$ & 0,19 & $-0,32$ & $-0,79$ & $-0,90$ & $-0,69$ \\
\hline 20 & 80 & 1,40 & 2,41 & gérb1 & $-0,13$ & $-0,13$ & $-0,14$ & 0,32 & $-0,13$ & $-0,79$ & $-0,99$ & $-0,63$ \\
\hline 21 & 80 & 1,40 & 3,81 & gérb1 & 0,15 & $-0,10$ & $-0,22$ & 0,51 & 0,15 & $-0,79$ & $-1,14$ & $-0,55$ \\
\hline 22 & 80 & 1,50 & 1,50 & gérb1 & $-0,32$ & $-0,16$ & $-0,09$ & 0,19 & $-0,32$ & $-0,79$ & $-0,90$ & $-0,69$ \\
\hline 23 & 80 & 1,50 & 2,41 & gérb1 & $-0,13$ & $-0,13$ & $-0,14$ & 0,32 & $-0,13$ & $-0,79$ & $-1,00$ & $-0,63$ \\
\hline 24 & 80 & 1,50 & 3,81 & gérb1 & 0,15 & $-0,10$ & $-0,23$ & 0,51 & 0,15 & $-0,79$ & $-1,15$ & $-0,55$ \\
\hline 25 & 100 & 1,10 & 1,50 & gérb1 & $-0,31$ & $-0,16$ & $-0,09$ & 0,19 & $-0,31$ & $-0,77$ & $-0,88$ & $-0,67$ \\
\hline 26 & 100 & 1,10 & 2,41 & gérb1 & $-0,12$ & $-0,13$ & $-0,14$ & 0,32 & $-0,12$ & $-0,77$ & $-0,97$ & $-0,60$ \\
\hline 27 & 100 & 1,10 & 3,81 & gérb1 & 0,17 & $-0,10$ & $-0,21$ & 0,52 & 0,17 & $-0,77$ & $-1,12$ & $-0,51$ \\
\hline 28 & 100 & 1,25 & 1,50 & gérb1 & $-0,31$ & $-0,16$ & $-0,09$ & 0,19 & $-0,31$ & $-0,77$ & $-0,88$ & $-0,67$ \\
\hline 29 & 100 & 1,25 & 2,41 & gérb1 & $-0,12$ & $-0,13$ & $-0,14$ & 0,32 & $-0,12$ & $-0,77$ & $-0,98$ & $-0,61$ \\
\hline 30 & 100 & 1,25 & 3,81 & gérb1 & 0,17 & $-0,10$ & $-0,22$ & 0,52 & 0,17 & $-0,77$ & $-1,12$ & $-0,52$ \\
\hline 31 & 100 & 1,40 & 1,50 & gérb1 & $-0,31$ & $-0,16$ & $-0,09$ & 0,19 & $-0,31$ & $-0,77$ & $-0,88$ & $-0,67$ \\
\hline 32 & 100 & 1,40 & 2,41 & gérb1 & $-0,12$ & $-0,13$ & $-0,14$ & 0,32 & $-0,12$ & $-0,77$ & $-0,98$ & $-0,61$ \\
\hline 33 & 100 & 1,40 & 3,81 & gérb1 & 0,17 & $-0,10$ & $-0,22$ & 0,52 & 0,17 & $-0,77$ & $-1,13$ & $-0,52$ \\
\hline 34 & 100 & 1,50 & 1,50 & gérb1 & $-0,31$ & $-0,16$ & $-0,09$ & 0,19 & $-0,31$ & $-0,77$ & $-0,89$ & $-0,67$ \\
\hline 35 & 100 & 1,50 & 2,41 & gérb1 & $-0,12$ & $-0,13$ & $-0,14$ & 0,32 & $-0,12$ & $-0,77$ & $-0,98$ & $-0,61$ \\
\hline 36 & 100 & 1,50 & 3,81 & gérb1 & 0,17 & $-0,10$ & $-0,22$ & 0,52 & 0,17 & $-0,77$ & $-1,13$ & $-0,52$ \\
\hline 1 & 75 & 1,10 & 1,50 & gérb2 & $-0,05$ & $-0,02$ & $-0,06$ & 0,15 & $-0,05$ & $-0,18$ & $-0,28$ & $-0,11$ \\
\hline 2 & 75 & 1,10 & 2,41 & gérb2 & 0,10 & 0,00 & $-0,10$ & 0,24 & 0,10 & $-0,17$ & $-0,34$ & $-0,05$ \\
\hline 3 & 75 & 1,10 & 3,81 & gérb2 & 0,34 & 0,03 & $-0,15$ & 0,38 & 0,34 & $-0,15$ & $-0,43$ & 0,03 \\
\hline 4 & 75 & 1,25 & 1,50 & gérb2 & $-0,05$ & $-0,02$ & $-0,06$ & 0,15 & $-0,05$ & $-0,18$ & $-0,28$ & $-0,11$ \\
\hline 5 & 75 & 1,25 & 2,41 & gérb2 & 0,10 & 0,00 & $-0,10$ & 0,24 & 0,10 & $-0,17$ & $-0,34$ & $-0,06$ \\
\hline 6 & 75 & 1,25 & 3,81 & gérb2 & 0,34 & 0,03 & $-0,16$ & 0,38 & 0,34 & $-0,15$ & $-0,43$ & 0,03 \\
\hline 7 & 75 & 1,40 & 1,50 & gérb2 & $-0,05$ & $-0,02$ & $-0,06$ & 0,15 & $-0,05$ & $-0,18$ & $-0,29$ & $-0,11$ \\
\hline 8 & 75 & 1,40 & 2,41 & gérb2 & 0,10 & 0,00 & $-0,10$ & 0,24 & 0,10 & $-0,17$ & $-0,34$ & $-0,06$ \\
\hline
\end{tabular}


Tabela 15. Principais resultados obtidos das simulações do segundo cenário logístico para cada um dos processos

\begin{tabular}{|c|c|c|c|c|c|c|c|c|c|c|c|c|}
\hline \multirow{2}{*}{$\begin{array}{l}\text { Si- } \\
\text { mu- } \\
\text { la- } \\
\text { ção }\end{array}$} & \multirow{2}{*}{$\begin{array}{c}\text { No. } \\
\text { Has- } \\
\text { tes }\end{array}$} & \multirow{2}{*}{$\begin{array}{l}\text { Fre- } \\
\text { te } \\
\text { Aé- } \\
\text { reo }\end{array}$} & \multirow{2}{*}{$\begin{array}{l}\text { Taxa } \\
\text { Câm } \\
\text {-bio }\end{array}$} & \multirow{2}{*}{$\begin{array}{c}\text { Tipo } \\
\text { de } \\
\text { flor }\end{array}$} & \multicolumn{4}{|c|}{$\begin{array}{l}\text { Lucro bruto unitário } \\
\text { por processo }\end{array}$} & \multicolumn{4}{|c|}{$\begin{array}{c}\text { Lucro líquido unitário } \\
\text { por processo }\end{array}$} \\
\hline & & & & & A & $\mathrm{B}$ & $\mathrm{C}$ & $\mathrm{D}$ & A & B & $\mathrm{C}$ & D \\
\hline 9 & 75 & 1,40 & 3,81 & gérb2 & 0,34 & 0,03 & $-0,16$ & 0,38 & 0,34 & $-0,15$ & $-0,43$ & 0,02 \\
\hline 10 & 75 & 1,50 & 1,50 & gérb2 & $-0,05$ & $-0,02$ & $-0,06$ & 0,15 & $-0,05$ & $-0,18$ & $-0,29$ & $-0,11$ \\
\hline 11 & 75 & 1,50 & 2,41 & gérb2 & 0,10 & 0,00 & $-0,10$ & 0,24 & 0,10 & $-0,17$ & $-0,35$ & $-0,06$ \\
\hline 12 & 75 & 1,50 & 3,81 & gérb2 & 0,34 & 0,03 & $-0,16$ & 0,38 & 0,34 & $-0,15$ & $-0,44$ & 0,02 \\
\hline 13 & 80 & 1,10 & 1,50 & gérb2 & $-0,04$ & $-0,02$ & $-0,06$ & 0,15 & $-0,04$ & $-0,18$ & $-0,28$ & $-0,10$ \\
\hline 14 & 80 & 1,10 & 2,41 & gérb2 & 0,11 & 0,00 & $-0,10$ & 0,24 & 0,11 & $-0,16$ & $-0,33$ & $-0,05$ \\
\hline 15 & 80 & 1,10 & 3,81 & gérb2 & 0,35 & 0,03 & $-0,15$ & 0,38 & 0,35 & $-0,14$ & $-0,42$ & 0,04 \\
\hline 16 & 80 & 1,25 & 1,50 & gérb2 & $-0,04$ & $-0,02$ & $-0,06$ & 0,15 & $-0,04$ & $-0,18$ & $-0,28$ & $-0,10$ \\
\hline 17 & 80 & 1,25 & 2,41 & gérb2 & 0,11 & 0,00 & $-0,10$ & 0,24 & 0,11 & $-0,16$ & $-0,34$ & $-0,05$ \\
\hline 18 & 80 & 1,25 & 3,81 & gérb2 & 0,35 & 0,03 & $-0,15$ & 0 , & 0,35 & $-0,14$ & $-0,42$ & 0,04 \\
\hline 19 & 80 & 1,40 & 1,50 & gérb2 & $-0,04$ & $-0,02$ & $-0,06$ & 0,15 & $-0,04$ & $-0,18$ & $-0,28$ & $-0,11$ \\
\hline 20 & 80 & 1,40 & 2,41 & gérb2 & 0,11 & 0,00 & $-0,10$ & 0,24 & 0,11 & $-0,16$ & $-0,34$ & $-0,05$ \\
\hline 21 & 80 & 1,40 & 3,81 & gérb2 & 0,35 & 0,03 & $-0,16$ & 0,38 & 0,35 & $-0,14$ & $-0,43$ & 0,03 \\
\hline 22 & 80 & 1,50 & 1,50 & gérb2 & $-0,04$ & $-0,02$ & $-0,06$ & 0,15 & $-0,04$ & $-0,18$ & $-0,28$ & $-0,11$ \\
\hline 23 & 80 & 1,50 & 2,41 & gérb2 & 0,11 & 0,00 & $-0,10$ & 0,24 & 0,11 & $-0,16$ & $-0,34$ & $-0,05$ \\
\hline 24 & 80 & 1,50 & 3,81 & gérb2 & 0,35 & 0,03 & $-0,16$ & & 0,35 & $-0,14$ & $-0,43$ & 0,03 \\
\hline 25 & 100 & 1,10 & 1,50 & gérb2 & $-0,03$ & $-0,02$ & & 0,1 & $-0,03$ & $-0,16$ & $-0,26$ & $-0,08$ \\
\hline 26 & 100 & 1,10 & 2,41 & gérb2 & 0,13 & 0,00 & $-0,09$ & 0,25 & 0,13 & $-0,15$ & $-0,32$ & $-0,02$ \\
\hline 27 & 100 & 1,10 & 3,81 & gérb2 & 0,36 & 0,03 & $-0,15$ & 0,39 & 0,36 & $-0,13$ & $-0,40$ & 0,07 \\
\hline 28 & 100 & 1,25 & 1,50 & gérb2 & $-0,03$ & $-0,02$ & $-0,06$ & 0,15 & $-0,03$ & $-0,16$ & $-0,26$ & $-0,08$ \\
\hline 29 & 100 & 1,25 & 2,41 & gérb2 & 0,13 & 0,00 & $-0,10$ & 0,25 & 0,13 & $-0,15$ & $-0,32$ & $-0,02$ \\
\hline 30 & 100 & 1,25 & 3,81 & gérb2 & 0,36 & 0,03 & $-0,15$ & 0,39 & 0,36 & $-0,13$ & $-0,40$ & 0,07 \\
\hline 31 & 100 & 1,40 & 1,50 & gérb2 & $-0,03$ & $-0,02$ & $-0,06$ & 0,15 & $-0,03$ & $-0,16$ & $-0,26$ & $-0,09$ \\
\hline 32 & 100 & 1,40 & 2,41 & gérb2 & 0,13 & 0,00 & $-0,10$ & 0,25 & 0,13 & $-0,15$ & $-0,32$ & $-0,03$ \\
\hline 33 & 100 & 1,40 & 3,81 & gérb2 & 0,36 & 0,03 & $-0,16$ & 0,39 & 0,36 & $-0,13$ & $-0,41$ & 0,06 \\
\hline 34 & 100 & 1,50 & 1,50 & gérb2 & $-0,03$ & $-0,02$ & $-0,06$ & 0,15 & $-0,03$ & $-0,16$ & $-0,26$ & $-0,09$ \\
\hline 35 & 100 & 1,50 & 2,41 & gérb2 & 0,13 & 0,00 & $-0,10$ & 0,25 & 0,13 & $-0,15$ & $-0,32$ & $-0,03$ \\
\hline 36 & 100 & 1,50 & 3,81 & gérb2 & 0,36 & 0,03 & $-0,16$ & 0,39 & 0,36 & $-0,13$ & $-0,41$ & 0,06 \\
\hline
\end{tabular}


Tabela 16. Principais resultados obtidos das simulações do terceiro cenário logístico para cada um dos processos

\begin{tabular}{|c|c|c|c|c|c|c|c|c|c|c|c|c|}
\hline \multirow{2}{*}{$\begin{array}{c}\text { Si- } \\
\text { mu- } \\
\text { la- } \\
\text { ção }\end{array}$} & \multirow{2}{*}{$\begin{array}{c}\text { No. } \\
\text { Has- } \\
\text { tes }\end{array}$} & \multirow{2}{*}{$\begin{array}{l}\text { Fre- } \\
\text { te } \\
\text { Aé- } \\
\text { reo }\end{array}$} & \multirow{2}{*}{$\begin{array}{c}\text { Taxa } \\
\text { Câm- } \\
\text { bio }\end{array}$} & \multirow{2}{*}{$\begin{array}{c}\text { Tipo } \\
\text { de } \\
\text { flor }\end{array}$} & \multicolumn{4}{|c|}{$\begin{array}{c}\text { Lucro bruto unitário } \\
\text { por processo }\end{array}$} & \multicolumn{4}{|c|}{$\begin{array}{c}\text { Lucro líquido unitário } \\
\text { por processo }\end{array}$} \\
\hline & & & & & A & B & $\mathrm{C}$ & $\mathrm{D}$ & A & B & $\mathrm{C}$ & $\mathrm{D}$ \\
\hline 1 & 75 & 1,10 & 1,50 & lírio & $-0,29$ & 0,31 & $-0,04$ & 0,41 & $-0,29$ & $-0,49$ & $-0,93$ & $-0,51$ \\
\hline 2 & 75 & 1,10 & 2,41 & lírio & 0,07 & 0,52 & $-0,07$ & 0,66 & 0,07 & $-0,33$ & $-1,04$ & $-0,37$ \\
\hline 3 & 75 & 1,10 & 3,81 & lírio & 0,53 & 0,86 & $-0,11$ & 1,04 & 0,53 & $-0,19$ & $-1,32$ & $-0,24$ \\
\hline 4 & 75 & 1,25 & 1,50 & lírio & $-0,29$ & 0,31 & $-0,05$ & 0,41 & $-0,29$ & $-0,49$ & $-0,93$ & $-0,51$ \\
\hline 5 & 75 & 1,25 & 2,41 & lírio & 0,07 & 0,52 & $-0,07$ & 0,66 & 0,07 & $-0,33$ & $-1,05$ & $-0,37$ \\
\hline 6 & 75 & 1,25 & 3,81 & lírio & 0,53 & 0,86 & $-0,12$ & 1,04 & 0,53 & $-0,19$ & $-1,32$ & $-0,25$ \\
\hline 7 & 75 & 1,40 & 1,50 & lírio & $-0,29$ & 0,31 & $-0,05$ & 0,41 & $-0,29$ & $-0,49$ & $-0,93$ & $-0,52$ \\
\hline 8 & 75 & 1,40 & 2,41 & lírio & 0,07 & 0,52 & $-0,08$ & 0,66 & 0,07 & $-0,33$ & $-1,05$ & $-0,37$ \\
\hline 9 & 75 & 1,40 & 3,81 & lírio & 0,53 & 0,86 & $-0,12$ & 1,04 & 0,53 & $-0,19$ & $-1,33$ & $-0,25$ \\
\hline 10 & 75 & 1,50 & 1,50 & lírio & $-0,29$ & 0,31 & $-0,05$ & 0,41 & $-0,29$ & $-0,49$ & $-0,93$ & $-0,52$ \\
\hline 11 & 75 & 1,50 & 2,41 & lírio & 0,07 & 0,52 & $-0,08$ & 0,66 & 0,07 & $-0,33$ & $-1,05$ & $-0,37$ \\
\hline 12 & 75 & 1,50 & 3,81 & lírio & 0,53 & 0,86 & $-0,12$ & 1,04 & 0,53 & $-0,19$ & $-1,33$ & $-0,25$ \\
\hline 13 & 80 & 1,10 & 1,50 & lírio & $-0,28$ & 0,31 & $-0,04$ & 0,41 & $-0,28$ & $-0,48$ & $-0,92$ & $-0,50$ \\
\hline 14 & 80 & 1,10 & 2,41 & lírio & 0,08 & 0,52 & $-0,07$ & 0,66 & 0,08 & $-0,32$ & $-1,03$ & $-0,35$ \\
\hline 15 & 80 & 1,10 & 3,81 & lírio & 0,54 & 0,86 & $-0,11$ & 1,05 & 0,54 & $-0,18$ & $-1,31$ & $-0,23$ \\
\hline 16 & 80 & 1,25 & 1,50 & lírio & $-0,28$ & 0,31 & $-0,05$ & 0,41 & $-0,28$ & $-0,48$ & $-0,92$ & $-0,50$ \\
\hline 17 & 80 & 1,25 & 2,41 & lírio & 0,08 & 0,52 & $-0,07$ & 0,66 & 0,08 & $-0,32$ & $-1,04$ & $-0,36$ \\
\hline 18 & 80 & 1,25 & 3,81 & lírio & 0,54 & 0,86 & $-0,12$ & 1,05 & 0,54 & $-0,18$ & $-1,31$ & $-0,23$ \\
\hline 19 & 80 & 1,40 & 1,50 & lírio & $-0,28$ & 0,31 & $-0,05$ & 0,41 & $-0,28$ & $-0,48$ & $-0,92$ & $-0,50$ \\
\hline 20 & 80 & 1,40 & 2,41 & lírio & 0,08 & 0,52 & $-0,08$ & 0,66 & 0,08 & $-0,32$ & $-1,04$ & $-0,36$ \\
\hline 21 & 80 & 1,40 & 3,81 & lírio & 0,54 & 0,86 & $-0,12$ & 1,05 & 0,54 & $-0,18$ & $-1,32$ & $-0,24$ \\
\hline 22 & 80 & 1,50 & 1,50 & lírio & $-0,28$ & 0,31 & $-0,05$ & 0,41 & $-0,28$ & $-0,48$ & $-0,92$ & $-0,51$ \\
\hline 23 & 80 & 1,50 & 2,41 & lírio & 0,08 & 0,52 & $-0,08$ & 0,66 & 0,08 & $-0,32$ & $-1,04$ & $-0,36$ \\
\hline 24 & 80 & 1,50 & 3,81 & lírio & 0,54 & 0,86 & $-0,12$ & 1,05 & 0,54 & $-0,18$ & $-1,32$ & $-0,24$ \\
\hline 25 & 100 & 1,10 & 1,50 & lírio & $-0,25$ & 0,31 & $-0,04$ & 0,41 & $-0,25$ & $-0,45$ & $-0,89$ & $-0,47$ \\
\hline 26 & 100 & 1,10 & 2,41 & lírio & 0,11 & 0,52 & $-0,07$ & 0,67 & 0,11 & $-0,29$ & $-1,00$ & $-0,32$ \\
\hline 27 & 100 & 1,10 & 3,81 & lírio & 0,57 & 0,86 & $-0,11$ & 1,06 & 0,57 & $-0,15$ & $-1,28$ & $-0,19$ \\
\hline 28 & 100 & 1,25 & 1,50 & lírio & $-0,25$ & 0,31 & $-0,04$ & 0,41 & $-0,25$ & $-0,45$ & $-0,89$ & $-0,47$ \\
\hline 29 & 100 & 1,25 & 2,41 & lírio & 0,11 & 0,52 & $-0,07$ & 0,67 & 0,11 & $-0,29$ & $-1,00$ & $-0,32$ \\
\hline 30 & 100 & 1,25 & 3,81 & lírio & 0,57 & 0,86 & $-0,11$ & 1,06 & 0,57 & $-0,15$ & $-1,28$ & $-0,19$ \\
\hline 31 & 100 & 1,40 & 1,50 & lírio & $-0,25$ & 0,31 & $-0,05$ & 0,41 & $-0,25$ & $-0,45$ & $-0,89$ & $-0,47$ \\
\hline 32 & 100 & 1,40 & 2,41 & lírio & 0,11 & 0,52 & $-0,07$ & 0,67 & 0,11 & $-0,29$ & $-1,01$ & $-0,32$ \\
\hline 33 & 100 & 1,40 & 3,81 & lírio & 0,57 & 0,86 & $-0,12$ & 1,06 & 0,57 & $-0,15$ & $-1,29$ & $-0,20$ \\
\hline 34 & 100 & 1,50 & 1,50 & lírio & $-0,25$ & 0,31 & $-0,05$ & 0,41 & $-0,25$ & $-0,45$ & $-0,89$ & $-0,47$ \\
\hline 35 & 100 & 1,50 & 2,41 & lírio & 0,11 & 0,52 & $-0,08$ & 0,67 & 0,11 & $-0,29$ & $-1,01$ & $-0,32$ \\
\hline 36 & 100 & 1,50 & 3,81 & lírio & 0,57 & 0,86 & $-0,12$ & 1,06 & 0,57 & $-0,15$ & $-1,29$ & $-0,20$ \\
\hline 1 & 75 & 1,10 & 1,50 & gérb1 & $-0,29$ & $-0,01$ & $-0,05$ & 0,19 & $-0,29$ & $-0,63$ & $-0,83$ & $-0,64$ \\
\hline 2 & 75 & 1,10 & 2,41 & gérb1 & $-0,09$ & 0,10 & $-0,08$ & 0,32 & $-0,09$ & $-0,54$ & $-0,90$ & $-0,57$ \\
\hline 3 & 75 & 1,10 & 3,81 & gérb1 & 0,21 & 0,26 & $-0,12$ & 0,52 & 0,21 & $-0,41$ & $-1,01$ & $-0,47$ \\
\hline 4 & 75 & 1,25 & 1,50 & gérb1 & $-0,29$ & $-0,01$ & $-0,05$ & 0,19 & $-0,29$ & $-0,63$ & $-0,84$ & $-0,64$ \\
\hline
\end{tabular}


Tabela 16. Principais resultados obtidos das simulações do terceiro cenário logístico para cada um dos processos

\begin{tabular}{|c|c|c|c|c|c|c|c|c|c|c|c|c|}
\hline \multirow{2}{*}{$\begin{array}{c}\text { Si- } \\
\text { mu- } \\
\text { la- } \\
\text { ção }\end{array}$} & \multirow{2}{*}{$\begin{array}{c}\text { No. } \\
\text { Has- } \\
\text { tes }\end{array}$} & \multirow{2}{*}{$\begin{array}{c}\text { Fre- } \\
\text { te } \\
\text { Aé- } \\
\text { reo }\end{array}$} & \multirow{2}{*}{$\begin{array}{c}\text { Taxa } \\
\text { Câm- } \\
\text { bio } \\
\end{array}$} & \multirow{2}{*}{$\begin{array}{c}\text { Tipo } \\
\text { de } \\
\text { flor }\end{array}$} & \multicolumn{4}{|c|}{$\begin{array}{l}\text { Lucro bruto unitário } \\
\text { por processo }\end{array}$} & \multicolumn{4}{|c|}{$\begin{array}{c}\text { Lucro líquido unitário } \\
\text { por processo }\end{array}$} \\
\hline & & & & & A & B & $\mathrm{C}$ & D & A & $\mathrm{B}$ & $\mathrm{C}$ & $\mathrm{D}$ \\
\hline 5 & 75 & 1,25 & 2,41 & gérb1 & $-0,09$ & 0,10 & $-0,08$ & 0,32 & $-0,09$ & $-0,54$ & $-0,90$ & $-0,57$ \\
\hline 6 & 75 & 1,25 & 3,81 & gérb1 & 0,21 & 0,26 & $-0,13$ & 0,52 & 0,21 & $-0,41$ & $-1,01$ & $-0,48$ \\
\hline 7 & 75 & 1,40 & 1,50 & gérb1 & $-0,29$ & $-0,01$ & $-0,05$ & 0,19 & $-0,29$ & $-0,63$ & $-0,84$ & $-0,64$ \\
\hline 8 & 75 & 1,40 & 2,41 & gérb1 & $-0,09$ & 0,10 & $-0,08$ & 0,32 & $-0,09$ & $-0,54$ & $-0,90$ & $-0,58$ \\
\hline 9 & 75 & 1,40 & 3,81 & gérb1 & 0,21 & 0,26 & $-0,13$ & 0,52 & 0,21 & $-0,41$ & $-1,01$ & $-0,48$ \\
\hline 10 & 75 & 1,50 & 1,50 & gérb1 & $-0,29$ & $-0,01$ & $-0,05$ & 0,19 & $-0,29$ & $-0,63$ & $-0,84$ & $-0,64$ \\
\hline 11 & 75 & 1,50 & 2,41 & gérb1 & $-0,09$ & 0,10 & $-0,08$ & 0,32 & $-0,09$ & $-0,54$ & $-0,91$ & $-0,58$ \\
\hline 12 & 75 & 1,50 & 3,81 & gérb1 & 0,21 & 0,26 & $-0,13$ & 0,52 & 0,21 & $-0,41$ & $-1,02$ & $-0,48$ \\
\hline 13 & 80 & 1,10 & 1,50 & gérb1 & $-0,29$ & $-0,01$ & $-0,05$ & 0,19 & $-0,29$ & $-0,62$ & $-0,83$ & $-0,63$ \\
\hline 14 & 80 & 1,10 & 2,41 & gérb1 & $-0,09$ & 0,10 & $-0,08$ & 0,32 & $-0,09$ & $-0,53$ & $-0,89$ & $-0,56$ \\
\hline 15 & 80 & 1,10 & 3,81 & gérb1 & 0,22 & 0,26 & $-0,12$ & 0,52 & 0,22 & $-0,40$ & $-1,00$ & $-0,47$ \\
\hline 16 & 80 & 1,25 & 1,50 & gérb1 & $-0,29$ & $-0,01$ & $-0,05$ & 0,19 & $-0,29$ & $-0,62$ & $-0,83$ & $-0,63$ \\
\hline 17 & 80 & 1,25 & 2,41 & gérb1 & $-0,09$ & 0,10 & $-0,08$ & 0,32 & $-0,09$ & $-0,53$ & $-0,90$ & $-0,57$ \\
\hline 18 & 80 & 1,25 & 3,81 & gérb1 & 0,22 & 0,26 & $-0,13$ & 0,52 & 0,22 & $-0,40$ & $-1,00$ & $-0,47$ \\
\hline 19 & 80 & 1,40 & 1,50 & gérb1 & $-0,29$ & $-0,01$ & $-0,05$ & 0,19 & $-0,29$ & $-0,62$ & $-0,83$ & $-0,64$ \\
\hline 20 & 80 & 1,40 & 2,41 & gérb1 & $-0,09$ & 0,10 & $-0,08$ & 0,32 & $-0,09$ & $-0,53$ & $-0,90$ & $-0,57$ \\
\hline 21 & 80 & 1,40 & 3,81 & gérb1 & 0,22 & 0,26 & $-0,13$ & 0,52 & 0,22 & $-0,40$ & $-1,01$ & $-0,47$ \\
\hline 22 & 80 & 1,50 & 1,50 & gérb1 & $-0,29$ & $-0,01$ & $-0,05$ & 0,19 & $-0,29$ & $-0,62$ & $-0,83$ & $-0,64$ \\
\hline 23 & 80 & 1,50 & 2,41 & gérb1 & $-0,09$ & 0,10 & $-0,08$ & 0,32 & $-0,09$ & $-0,53$ & $-0,90$ & $-0,57$ \\
\hline 24 & 80 & 1,50 & 3,81 & gérb1 & 0,22 & 0,26 & $-0,13$ & 0,52 & 0,22 & $-0,40$ & $-1,01$ & $-0,48$ \\
\hline 25 & 100 & 1,10 & 1,50 & gérb1 & $-0,27$ & $-0,01$ & $-0,05$ & 0,20 & $-0,27$ & $-0,61$ & $-0,81$ & $-0,61$ \\
\hline 26 & 100 & 1,10 & 2,41 & gérb1 & $-0,07$ & 0,10 & $-0,08$ & 0,33 & $-0,07$ & $-0,52$ & $-0,88$ & $-0,54$ \\
\hline 27 & 100 & 1,10 & 3,81 & gérb1 & 0,23 & 0,26 & $-0,12$ & 0,53 & 0,23 & $-0,39$ & $-0,98$ & $-0,44$ \\
\hline 28 & 100 & 1,25 & 1,50 & gérb1 & $-0,27$ & $-0,01$ & $-0,05$ & 0,20 & $-0,27$ & $-0,61$ & $-0,81$ & $-0,62$ \\
\hline 29 & 100 & 1,25 & 2,41 & gérb1 & $-0,07$ & 0,10 & $-0,08$ & 0,33 & $-0,07$ & $-0,52$ & $-0,88$ & $-0,54$ \\
\hline 30 & 100 & 1,25 & 3,81 & gérb1 & 0,23 & 0,26 & $-0,12$ & 0,53 & 0,23 & $-0,39$ & $-0,99$ & $-0,44$ \\
\hline 31 & 100 & 1,40 & 1,50 & gérb1 & $-0,27$ & $-0,01$ & $-0,05$ & 0,20 & $-0,27$ & $-0,61$ & $-0,82$ & $-0,62$ \\
\hline 32 & 100 & 1,40 & 2,41 & gérb1 & $-0,07$ & 0,10 & $-0,08$ & 0,33 & $-0,07$ & $-0,52$ & $-0,88$ & $-0,55$ \\
\hline 33 & 100 & 1,40 & 3,81 & gérb1 & 0,23 & 0,26 & $-0,13$ & 0,53 & 0,23 & $-0,39$ & $-0,99$ & $-0,45$ \\
\hline 34 & 100 & 1,50 & 1,50 & gérb1 & $-0,27$ & $-0,01$ & $-0,05$ & 0,20 & $-0,27$ & $-0,61$ & $-0,82$ & $-0,62$ \\
\hline 35 & 100 & 1,50 & 2,41 & gérb1 & $-0,07$ & 0,10 & $-0,08$ & 0,33 & $-0,07$ & $-0,52$ & $-0,89$ & $-0,55$ \\
\hline 36 & 100 & 1,50 & 3,81 & gérb1 & 0,23 & 0,26 & $-0,13$ & 0,53 & 0,23 & $-0,39$ & $-0,99$ & $-0,45$ \\
\hline 1 & 75 & 1,10 & 1,50 & gérb2 & $-0,03$ & 0,09 & $-0,03$ & 0,15 & $-0,03$ & $-0,07$ & $-0,25$ & $-0,09$ \\
\hline 2 & 75 & 1,10 & 2,41 & gérb2 & 0,13 & 0,17 & $-0,05$ & 0,24 & 0,13 & 0,01 & $-0,28$ & $-0,03$ \\
\hline 3 & 75 & 1,10 & 3,81 & gérb2 & 0,38 & 0,31 & $-0,08$ & 0,39 & 0,38 & 0,14 & $-0,34$ & 0,06 \\
\hline 4 & 75 & 1,25 & 1,50 & gérb2 & $-0,03$ & 0,09 & $-0,03$ & 0,15 & $-0,03$ & $-0,07$ & $-0,25$ & $-0,09$ \\
\hline 5 & 75 & 1,25 & 2,41 & gérb2 & 0,13 & 0,17 & $-0,05$ & 0,24 & 0,13 & 0,01 & $-0,29$ & $-0,03$ \\
\hline 6 & 75 & 1,25 & 3,81 & gérb2 & 0,38 & 0,31 & $-0,08$ & 0,39 & 0,38 & 0,14 & $-0,34$ & 0,06 \\
\hline 7 & 75 & 1,40 & 1,50 & gérb2 & $-0,03$ & 0,09 & $-0,03$ & 0,15 & $-0,03$ & $-0,07$ & $-0,25$ & $-0,10$ \\
\hline 8 & 75 & 1,40 & 2,41 & gérb2 & 0,13 & 0,17 & $-0,06$ & 0,24 & 0,13 & 0,01 & $-0,29$ & $-0,04$ \\
\hline
\end{tabular}


Tabela 16. Principais resultados obtidos das simulações do terceiro cenário logístico para cada um dos processos

\begin{tabular}{|c|c|c|c|c|c|c|c|c|c|c|c|c|}
\hline \multirow{2}{*}{$\begin{array}{l}\text { Si- } \\
\text { mu- } \\
\text { la- } \\
\text { ção }\end{array}$} & \multirow{2}{*}{$\begin{array}{c}\text { No. } \\
\text { Has- } \\
\text { tes }\end{array}$} & \multirow{2}{*}{$\begin{array}{c}\text { Fre- } \\
\text { te } \\
\text { Aé- } \\
\text { reo }\end{array}$} & \multirow{2}{*}{$\begin{array}{c}\text { Taxa } \\
\text { Câm- } \\
\text { bio } \\
\end{array}$} & \multirow{2}{*}{$\begin{array}{c}\text { Tipo } \\
\text { de } \\
\text { flor }\end{array}$} & \multicolumn{4}{|c|}{$\begin{array}{l}\text { Lucro bruto unitário } \\
\text { por processo }\end{array}$} & \multicolumn{4}{|c|}{$\begin{array}{c}\text { Lucro líquido unitário } \\
\text { por processo }\end{array}$} \\
\hline & & & & & A & $\mathrm{B}$ & $\mathrm{C}$ & $\mathrm{D}$ & A & $\mathrm{B}$ & $\mathrm{C}$ & $\mathrm{D}$ \\
\hline 9 & 75 & 1,40 & 3,81 & gérb2 & 0,38 & 0,31 & $-0,09$ & 0,39 & 0,38 & 0,14 & $-0,35$ & 0,05 \\
\hline 10 & 75 & 1,50 & 1,50 & gérb2 & $-0,03$ & 0,09 & $-0,04$ & 0,15 & $-0,03$ & $-0,07$ & $-0,25$ & $-0,10$ \\
\hline 11 & 75 & 1,50 & 2,41 & gérb2 & 0,13 & 0,17 & $-0,06$ & 0,24 & 0,13 & 0,01 & $-0,29$ & $-0,04$ \\
\hline 12 & 75 & 1,50 & 3,81 & gérb2 & 0,38 & 0,31 & $-0,09$ & 0,39 & 0,38 & 0,14 & $-0,35$ & 0,05 \\
\hline 13 & 80 & 1,10 & 1,50 & gérb2 & $-0,02$ & 0,09 & $-0,03$ & 0,15 & $-0,02$ & $-0,06$ & $-0,24$ & $-0,09$ \\
\hline 14 & 80 & 1,10 & 2,41 & gérb2 & 0,14 & 0,17 & $-0,05$ & 0,24 & 0,14 & 0,02 & $-0,28$ & $-0,02$ \\
\hline 15 & 80 & 1,10 & 3,81 & gérb2 & 0,39 & 0,31 & $-0,08$ & 0,39 & 0,39 & 0,14 & $-0,33$ & 0,07 \\
\hline 16 & 80 & 1,25 & 1,50 & gérb2 & $-0,02$ & 0,09 & $-0,03$ & 0,15 & $-0,02$ & $-0,06$ & $-0,24$ & $-0,09$ \\
\hline 17 & 80 & 1,25 & 2,41 & gérb2 & 0,14 & 0,17 & $-0,05$ & 0,24 & 0,14 & 0,02 & $-0,28$ & $-0,03$ \\
\hline 18 & 80 & 1,25 & 3,81 & gérb2 & 0,39 & 0,31 & $-0,08$ & 0 , & 0,39 & 0,14 & $-0,34$ & 0,07 \\
\hline 19 & 80 & 1,40 & 1,50 & gérb2 & $-0,02$ & 0,09 & $-0,03$ & 0,15 & $-0,02$ & $-0,06$ & $-0,24$ & $-0,09$ \\
\hline 20 & 80 & 1,40 & 2,41 & gérb2 & 0,14 & 0,17 & $-0,06$ & 0,24 & 0,14 & 0,02 & $-0,28$ & $-0,03$ \\
\hline 21 & 80 & 1,40 & 3,81 & gérb2 & 0,39 & 0,31 & $-0,09$ & 0,39 & 0,39 & 0,14 & $-0,34$ & 0,06 \\
\hline 22 & 80 & 1,50 & 1,50 & gérb2 & $-0,02$ & 0,09 & $-0,04$ & 0,15 & $-0,02$ & $-0,06$ & $-0,24$ & $-0,09$ \\
\hline 23 & 80 & 1,50 & 2,41 & gérb2 & 0,14 & 0,17 & $-0,06$ & 0,24 & 0,14 & 0,02 & $-0,28$ & $-0,03$ \\
\hline 24 & 80 & 1,50 & 81 & gérb2 & 0,39 & 0,31 & & & 0,39 & 0 & $-0,34$ & 0,06 \\
\hline 25 & 100 & 1,10 & 1,50 & gérb2 & $-0,01$ & 0,09 & & & $-0,01$ & $-0,05$ & $-0,22$ & $-0,07$ \\
\hline 26 & 100 & 1,10 & 2,41 & gérb2 & 0,15 & 0,17 & $-0,05$ & 0,25 & 0,15 & 0,03 & $-0,26$ & 0,00 \\
\hline 27 & 100 & 1,10 & 3,81 & gérb2 & 0,40 & 0,31 & $-0,08$ & 0,40 & 0,40 & 0,16 & $-0,32$ & 0,10 \\
\hline 28 & 100 & 1,25 & 1,50 & gérb2 & $-0,01$ & 0,09 & $-0,03$ & 0,15 & $-0,01$ & $-0,05$ & $-0,23$ & $-0,07$ \\
\hline 29 & 100 & 1,25 & 2,41 & gérb2 & 0,15 & 0,17 & $-0,05$ & 0,25 & 0,15 & 0,03 & $-0,26$ & 0,00 \\
\hline 30 & 100 & 1,25 & 3,81 & gérb2 & 0,40 & 0,31 & $-0,08$ & 0,40 & 0,40 & 0,16 & $-0,32$ & 0,09 \\
\hline 31 & 100 & 1,40 & 1,50 & gérb2 & $-0,01$ & 0,09 & $-0,03$ & 0,15 & $-0,01$ & $-0,05$ & $-0,23$ & $-0,07$ \\
\hline 32 & 100 & 1,40 & 2,41 & gérb2 & 0,15 & 0,17 & $-0,05$ & 0,25 & 0,15 & 0,03 & $-0,26$ & $-0,01$ \\
\hline 33 & 100 & 1,40 & 3,81 & gérb2 & 0,40 & 0,31 & $-0,08$ & 0,40 & 0,40 & 0,16 & $-0,32$ & 0,09 \\
\hline 34 & 100 & 1,50 & 1,50 & gérb2 & $-0,01$ & 0,09 & $-0,03$ & 0,15 & $-0,01$ & $-0,05$ & $-0,23$ & $-0,07$ \\
\hline 35 & 100 & 1,50 & 2,41 & gérb2 & 0,15 & 0,17 & $-0,06$ & 0,25 & 0,15 & 0,03 & $-0,27$ & $-0,01$ \\
\hline 36 & 100 & 1,50 & 3,81 & gérb2 & 0,40 & 0,31 & $-0,09$ & 0,40 & 0,40 & 0,16 & $-0,33$ & 0,09 \\
\hline
\end{tabular}


Tabela 17. Principais resultados obtidos das simulações do quarto cenário logístico para cada um dos processos

\begin{tabular}{|c|c|c|c|c|c|c|c|c|c|c|c|c|}
\hline \multirow{2}{*}{$\begin{array}{l}\text { Si- } \\
\text { mu- } \\
\text { la- } \\
\text { ção }\end{array}$} & \multirow{2}{*}{$\begin{array}{c}\text { No. } \\
\text { Has- } \\
\text { tes }\end{array}$} & \multirow{2}{*}{$\begin{array}{c}\text { Fre- } \\
\text { te } \\
\text { Aé- } \\
\text { reo }\end{array}$} & \multirow{2}{*}{$\begin{array}{c}\text { Taxa } \\
\text { Câm- } \\
\text { bio }\end{array}$} & \multirow{2}{*}{$\begin{array}{l}\text { Tipo } \\
\text { de } \\
\text { flor }\end{array}$} & \multicolumn{4}{|c|}{$\begin{array}{l}\text { Lucro bruto unitário } \\
\text { por processo }\end{array}$} & \multicolumn{4}{|c|}{$\begin{array}{c}\text { Lucro líquido unitário } \\
\text { por processo }\end{array}$} \\
\hline & & & & & A & B & C & D & A & B & C & D \\
\hline 1 & 75 & 1,10 & 1,50 & lírio & $-0,39$ & 0,01 & $-0,11$ & 0,40 & $-0,39$ & $-0,85$ & $-1,09$ & $-0,64$ \\
\hline 2 & 75 & 1,10 & 2,41 & lírio & $-0,05$ & 0,06 & $-0,18$ & 0,65 & $-0,05$ & $-0,87$ & $-1,26$ & $-0,51$ \\
\hline 3 & 75 & 1,10 & 3,81 & lírio & 0,36 & 0,14 & $-0,29$ & 1,03 & 0,36 & $-1,01$ & $-1,63$ & $-0,43$ \\
\hline 4 & 75 & 1,25 & 1,50 & lírio & $-0,39$ & 0,01 & $-0,12$ & 0,40 & $-0,39$ & $-0,85$ & $-1,10$ & $-0,64$ \\
\hline 5 & 75 & 1,25 & 2,41 & lírio & $-0,05$ & 0,06 & $-0,19$ & 0,65 & $-0,05$ & $-0,87$ & $-1,26$ & $-0,51$ \\
\hline 6 & 75 & 1,25 & 3,81 & lírio & 0,36 & 0,14 & $-0,29$ & 1,03 & 0,36 & $-1,01$ & $-1,64$ & $-0,43$ \\
\hline 7 & 75 & 1,40 & 1,50 & lírio & $-0,39$ & 0,01 & $-0,12$ & 0,40 & $-0,39$ & $-0,85$ & $-1,10$ & $-0,64$ \\
\hline 8 & 75 & 1,40 & 2,41 & lírio & $-0,05$ & 0,06 & $-0,19$ & 0,65 & $-0,05$ & $-0,87$ & $-1,27$ & $-0,51$ \\
\hline 9 & 75 & 1,40 & 3,81 & lírio & 0,36 & 0,14 & $-0,30$ & 1,03 & 0,36 & $-1,01$ & $-1,64$ & $-0,43$ \\
\hline 10 & 75 & 1,50 & 1,50 & lírio & $-0,39$ & 0,01 & $-0,12$ & 0,40 & $-0,39$ & $-0,85$ & $-1,10$ & $-0,64$ \\
\hline 11 & 75 & 1,50 & 2,41 & lírio & $-0,05$ & 0,06 & $-0,19$ & 0,65 & $-0,05$ & $-0,87$ & $-1,27$ & $-0,51$ \\
\hline 12 & 75 & 1,50 & 3,81 & lírio & 0,36 & 0,14 & $-0,30$ & 1,03 & 0,36 & $-1,01$ & $-1,64$ & $-0,44$ \\
\hline 13 & 80 & 1,10 & 1,50 & lírio & $-0,38$ & 0,01 & $-0,11$ & 0,40 & $-0,38$ & $-0,84$ & $-1,08$ & $-0,62$ \\
\hline 14 & 80 & 1,10 & 2,41 & lírio & $-0,04$ & 0,06 & $-0,18$ & 0,65 & $-0,04$ & $-0,86$ & $-1,25$ & $-0,49$ \\
\hline 15 & 80 & 1,10 & 3,81 & lírio & 0,37 & 0,14 & $-0,29$ & 1,03 & 0,37 & $-1,00$ & $-1,62$ & $-0,41$ \\
\hline 16 & 80 & 1,25 & 1,50 & lírio & $-0,38$ & 0,01 & $-0,12$ & 0,40 & $-0,38$ & $-0,84$ & $-1,09$ & $-0,63$ \\
\hline 17 & 80 & 1,25 & 2,41 & lírio & $-0,04$ & 0,06 & $-0,19$ & 0,65 & $-0,04$ & $-0,86$ & $-1,25$ & $-0,50$ \\
\hline 18 & 80 & 1,25 & 3,81 & lírio & 0,37 & 0,14 & $-0,29$ & 1,03 & 0,37 & $-1,00$ & $-1,62$ & $-0,41$ \\
\hline 19 & 80 & 1,40 & 1,50 & lírio & $-0,38$ & 0,01 & $-0,12$ & 0,40 & $-0,38$ & $-0,84$ & $-1,09$ & $-0,63$ \\
\hline 20 & 80 & 1,40 & 2,41 & lírio & $-0,04$ & 0,06 & $-0,19$ & 0,65 & $-0,04$ & $-0,86$ & $-1,26$ & $-0,50$ \\
\hline 21 & 80 & 1,40 & 3,81 & lírio & 0,37 & 0,14 & $-0,30$ & 1,03 & 0,37 & $-1,00$ & $-1,63$ & $-0,42$ \\
\hline 22 & 80 & 1,50 & 1,50 & lírio & $-0,38$ & 0,01 & $-0,12$ & 0,40 & $-0,38$ & $-0,84$ & $-1,09$ & $-0,63$ \\
\hline 23 & 80 & 1,50 & 2,41 & lírio & $-0,04$ & 0,06 & $-0,19$ & 0,65 & $-0,04$ & $-0,86$ & $-1,26$ & $-0,50$ \\
\hline 24 & 80 & 1,50 & 3,81 & lírio & 0,37 & 0,14 & $-0,30$ & 1,03 & 0,37 & $-1,00$ & $-1,63$ & $-0,42$ \\
\hline 25 & 100 & 1,10 & 1,50 & lírio & $-0,35$ & 0,02 & $-0,11$ & 0,41 & $-0,35$ & $-0,81$ & $-1,05$ & $-0,59$ \\
\hline 26 & 100 & 1,10 & 2,41 & lírio & $-0,01$ & 0,07 & $-0,18$ & 0,66 & $-0,01$ & $-0,83$ & $-1,22$ & $-0,45$ \\
\hline 27 & 100 & 1,10 & 3,81 & lírio & 0,40 & 0,14 & $-0,29$ & 1,04 & 0,40 & $-0,97$ & $-1,59$ & $-0,37$ \\
\hline 28 & 100 & 1,25 & 1,50 & lírio & $-0,35$ & 0,02 & $-0,12$ & 0,41 & $-0,35$ & $-0,81$ & $-1,05$ & $-0,59$ \\
\hline 29 & 100 & 1,25 & 2,41 & lírio & $-0,01$ & 0,07 & $-0,18$ & 0,66 & $-0,01$ & $-0,83$ & $-1,22$ & $-0,46$ \\
\hline 30 & 100 & 1,25 & 3,81 & lírio & 0,40 & 0,14 & $-0,29$ & 1,04 & 0,40 & $-0,97$ & $-1,59$ & $-0,37$ \\
\hline 31 & 100 & 1,40 & 1,50 & lírio & $-0,35$ & 0,02 & $-0,12$ & 0,41 & $-0,35$ & $-0,81$ & $-1,05$ & $-0,59$ \\
\hline 32 & 100 & 1,40 & 2,41 & lírio & $-0,01$ & 0,07 & $-0,19$ & 0,66 & $-0,01$ & $-0,83$ & $-1,22$ & $-0,46$ \\
\hline 33 & 100 & 1,40 & 3,81 & lírio & 0,40 & 0,14 & $-0,30$ & 1,04 & 0,40 & $-0,97$ & $-1,59$ & $-0,37$ \\
\hline 34 & 100 & 1,50 & 1,50 & lírio & $-0,35$ & 0,02 & $-0,12$ & 0,41 & $-0,35$ & $-0,81$ & $-1,05$ & $-0,59$ \\
\hline 35 & 100 & 1,50 & 2,41 & lírio & $-0,01$ & 0,07 & $-0,19$ & 0,66 & $-0,01$ & $-0,83$ & $-1,22$ & $-0,46$ \\
\hline 36 & 100 & 1,50 & 3,81 & lírio & 0,40 & 0,14 & $-0,30$ & 1,04 & 0,40 & $-0,97$ & $-1,60$ & $-0,38$ \\
\hline 1 & 75 & 1,10 & 1,50 & gérb1 & $-0,36$ & $-0,19$ & $-0,09$ & 0,19 & $-0,36$ & $-0,86$ & $-0,96$ & $-0,76$ \\
\hline 2 & 75 & 1,10 & 2,41 & gérb1 & $-0,17$ & $-0,16$ & $-0,14$ & 0,32 & $-0,17$ & $-0,86$ & $-1,06$ & $-0,70$ \\
\hline 3 & 75 & 1,10 & 3,81 & gérb1 & 0,12 & $-0,13$ & $-0,22$ & 0,51 & 0,12 & $-0,87$ & $-1,21$ & $-0,62$ \\
\hline 4 & 75 & 1,25 & 1,50 & gérb1 & $-0,36$ & $-0,19$ & $-0,09$ & 0,19 & $-0,36$ & $-0,86$ & $-0,96$ & $-0,76$ \\
\hline
\end{tabular}


Tabela 17. Principais resultados obtidos das simulações do quarto cenário logístico para cada um dos processos

\begin{tabular}{|c|c|c|c|c|c|c|c|c|c|c|c|c|}
\hline \multirow{2}{*}{$\begin{array}{c}\text { Si- } \\
\text { mu- } \\
\text { la- } \\
\text { ção }\end{array}$} & \multirow{2}{*}{$\begin{array}{c}\text { No. } \\
\text { Has- } \\
\text { tes }\end{array}$} & \multirow{2}{*}{$\begin{array}{l}\text { Fre- } \\
\text { te } \\
\text { Aé- } \\
\text { reo }\end{array}$} & \multirow{2}{*}{$\begin{array}{c}\text { Taxa } \\
\text { Câm- } \\
\text { bio }\end{array}$} & \multirow{2}{*}{$\begin{array}{c}\text { Tipo } \\
\text { de } \\
\text { flor }\end{array}$} & \multicolumn{4}{|c|}{$\begin{array}{c}\text { Lucro bruto unitário } \\
\text { por processo }\end{array}$} & \multicolumn{4}{|c|}{$\begin{array}{c}\text { Lucro líquido unitário } \\
\text { por processo }\end{array}$} \\
\hline & & & & & A & B & $\mathrm{C}$ & $\mathrm{D}$ & A & B & $\mathrm{C}$ & $\mathrm{D}$ \\
\hline 5 & 75 & 1,25 & 2,41 & gérb1 & $-0,17$ & $-0,16$ & $-0,14$ & 0,32 & $-0,17$ & $-0,86$ & $-1,06$ & $-0,70$ \\
\hline 6 & 75 & 1,25 & 3,81 & gérb1 & 0,12 & $-0,13$ & $-0,22$ & 0,51 & 0,12 & $-0,87$ & $-1,21$ & $-0,62$ \\
\hline 7 & 75 & 1,40 & 1,50 & gérb1 & $-0,36$ & $-0,19$ & $-0,09$ & 0,19 & $-0,36$ & $-0,86$ & $-0,96$ & $-0,76$ \\
\hline 8 & 75 & 1,40 & 2,41 & gérb1 & $-0,17$ & $-0,16$ & $-0,14$ & 0,32 & $-0,17$ & $-0,86$ & $-1,06$ & $-0,70$ \\
\hline 9 & 75 & 1,40 & 3,81 & gérb1 & 0,12 & $-0,13$ & $-0,23$ & 0,51 & 0,12 & $-0,87$ & $-1,21$ & $-0,62$ \\
\hline 10 & 75 & 1,50 & 1,50 & gérb1 & $-0,36$ & $-0,19$ & $-0,09$ & 0,19 & $-0,36$ & $-0,86$ & $-0,97$ & $-0,76$ \\
\hline 11 & 75 & 1,50 & 2,41 & gérb1 & $-0,17$ & $-0,16$ & $-0,15$ & 0,32 & $-0,17$ & $-0,86$ & $-1,06$ & $-0,70$ \\
\hline 12 & 75 & 1,50 & 3,81 & gérb1 & 0,12 & $-0,13$ & $-0,23$ & 0,51 & 0,12 & $-0,87$ & $-1,22$ & $-0,63$ \\
\hline 13 & 80 & 1,10 & 1,50 & gérb1 & $-0,35$ & $-0,18$ & $-0,09$ & 0,19 & $-0,35$ & $-0,85$ & $-0,96$ & $-0,75$ \\
\hline 14 & 80 & 1,10 & 2,41 & gérb1 & $-0,16$ & $-0,16$ & $-0,14$ & 0,32 & $-0,16$ & $-0,85$ & $-1,05$ & $-0,69$ \\
\hline 15 & 80 & 1,10 & 3,81 & gérb1 & 0,12 & $-0,13$ & $-0,22$ & 0,51 & 0,12 & $-0,86$ & $-1,20$ & $-0,61$ \\
\hline 16 & 80 & 1,25 & 1,50 & gérb1 & $-0,35$ & $-0,18$ & $-0,09$ & 0,19 & $-0,35$ & $-0,85$ & $-0,96$ & $-0,75$ \\
\hline 17 & 80 & 1,25 & 2,41 & gérb1 & $-0,16$ & $-0,16$ & $-0,14$ & 0,32 & $-0,16$ & $-0,85$ & $-1,05$ & $-0,69$ \\
\hline 18 & 80 & 1,25 & 3,81 & gérb1 & 0,12 & $-0,13$ & $-0,22$ & 0,51 & 0,12 & $-0,86$ & $-1,20$ & $-0,61$ \\
\hline 19 & 80 & 1,40 & 1,50 & gérb1 & $-0,35$ & $-0,18$ & $-0,09$ & 0,19 & $-0,35$ & $-0,85$ & $-0,96$ & $-0,75$ \\
\hline 20 & 80 & 1,40 & 2,41 & gérb1 & $-0,16$ & $-0,16$ & $-0,14$ & 0,32 & $-0,16$ & $-0,85$ & $-1,05$ & $-0,69$ \\
\hline 21 & 80 & 1,40 & 3,81 & gérb1 & 0,12 & $-0,13$ & $-0,23$ & 0,51 & 0,12 & $-0,86$ & $-1,21$ & $-0,61$ \\
\hline 22 & 80 & 1,50 & 1,50 & gérb1 & $-0,35$ & $-0,18$ & $-0,09$ & 0,19 & $-0,35$ & $-0,85$ & $-0,96$ & $-0,75$ \\
\hline 23 & 80 & 1,50 & 2,41 & gérb1 & $-0,16$ & $-0,16$ & $-0,15$ & 0,32 & $-0,16$ & $-0,85$ & $-1,06$ & $-0,70$ \\
\hline 24 & 80 & 1,50 & 3,81 & gérb1 & 0,12 & $-0,13$ & $-0,23$ & 0,51 & 0,12 & $-0,86$ & $-1,21$ & $-0,62$ \\
\hline 25 & 100 & 1,10 & 1,50 & gérb1 & $-0,34$ & $-0,18$ & $-0,09$ & 0,19 & $-0,34$ & $-0,83$ & $-0,94$ & $-0,73$ \\
\hline 26 & 100 & 1,10 & 2,41 & gérb1 & $-0,15$ & $-0,16$ & $-0,14$ & 0,32 & $-0,15$ & $-0,84$ & $-1,03$ & $-0,66$ \\
\hline 27 & 100 & 1,10 & 3,81 & gérb1 & 0,14 & $-0,13$ & $-0,22$ & 0,52 & 0,14 & $-0,84$ & $-1,18$ & $-0,58$ \\
\hline 28 & 100 & 1,25 & 1,50 & gérb1 & $-0,34$ & $-0,18$ & $-0,09$ & 0,19 & $-0,34$ & $-0,83$ & $-0,94$ & $-0,73$ \\
\hline 29 & 100 & 1,25 & 2,41 & gérb1 & $-0,15$ & $-0,16$ & $-0,14$ & 0,32 & $-0,15$ & $-0,84$ & $-1,03$ & $-0,67$ \\
\hline 30 & 100 & 1,25 & 3,81 & gérb1 & 0,14 & $-0,13$ & $-0,22$ & 0,52 & 0,14 & $-0,84$ & $-1,18$ & $-0,58$ \\
\hline 31 & 100 & 1,40 & 1,50 & gérb1 & $-0,34$ & $-0,18$ & $-0,09$ & 0,19 & $-0,34$ & $-0,83$ & $-0,94$ & $-0,73$ \\
\hline 32 & 100 & 1,40 & 2,41 & gérb1 & $-0,15$ & $-0,16$ & $-0,14$ & 0,32 & $-0,15$ & $-0,84$ & $-1,04$ & $-0,67$ \\
\hline 33 & 100 & 1,40 & 3,81 & gérb1 & 0,14 & $-0,13$ & $-0,22$ & 0,52 & 0,14 & $-0,84$ & $-1,19$ & $-0,59$ \\
\hline 34 & 100 & 1,50 & 1,50 & gérb1 & $-0,34$ & $-0,18$ & $-0,09$ & 0,19 & $-0,34$ & $-0,83$ & $-0,94$ & $-0,73$ \\
\hline 35 & 100 & 1,50 & 2,41 & gérb1 & $-0,15$ & $-0,16$ & $-0,14$ & 0,32 & $-0,15$ & $-0,84$ & $-1,04$ & $-0,67$ \\
\hline 36 & 100 & 1,50 & 3,81 & gérb1 & 0,14 & $-0,13$ & $-0,23$ & 0,52 & 0,14 & $-0,84$ & $-1,19$ & $-0,59$ \\
\hline 1 & 75 & 1,10 & 1,50 & gérb2 & $-0,06$ & $-0,04$ & $-0,06$ & 0,15 & $-0,06$ & $-0,21$ & $-0,31$ & $-0,13$ \\
\hline 2 & 75 & 1,10 & 2,41 & gérb2 & 0,09 & $-0,02$ & $-0,10$ & 0,24 & 0,09 & $-0,20$ & $-0,36$ & $-0,08$ \\
\hline 3 & 75 & 1,10 & 3,81 & gérb2 & 0,33 & 0,01 & $-0,15$ & 0,38 & 0,33 & $-0,18$ & $-0,45$ & 0,01 \\
\hline 4 & 75 & 1,25 & 1,50 & gérb2 & $-0,06$ & $-0,04$ & $-0,06$ & 0,15 & $-0,06$ & $-0,21$ & $-0,31$ & $-0,14$ \\
\hline 5 & 75 & 1,25 & 2,41 & gérb2 & 0,09 & $-0,02$ & $-0,10$ & 0,24 & 0,09 & $-0,20$ & $-0,36$ & $-0,08$ \\
\hline 6 & 75 & 1,25 & 3,81 & gérb2 & 0,33 & 0,01 & $-0,16$ & 0,38 & 0,33 & $-0,18$ & $-0,45$ & 0,00 \\
\hline 7 & 75 & 1,40 & 1,50 & gérb2 & $-0,06$ & $-0,04$ & $-0,06$ & 0,15 & $-0,06$ & $-0,21$ & $-0,31$ & $-0,14$ \\
\hline 8 & 75 & 1,40 & 2,41 & gérb2 & 0,09 & $-0,02$ & $-0,10$ & 0,24 & 0,09 & $-0,20$ & $-0,37$ & $-0,08$ \\
\hline
\end{tabular}


Tabela 17. Principais resultados obtidos das simulações do quarto cenário logístico para cada um dos processos

\begin{tabular}{|c|c|c|c|c|c|c|c|c|c|c|c|c|}
\hline \multirow{2}{*}{$\begin{array}{l}\text { Si- } \\
\text { mu- } \\
\text { la- } \\
\text { ção }\end{array}$} & \multirow{2}{*}{$\begin{array}{c}\text { No. } \\
\text { Has- } \\
\text { tes }\end{array}$} & \multirow{2}{*}{$\begin{array}{c}\text { Fre- } \\
\text { te } \\
\text { Aé- } \\
\text { reo }\end{array}$} & \multirow{2}{*}{$\begin{array}{c}\text { Taxa } \\
\text { Câm- } \\
\text { bio }\end{array}$} & \multirow{2}{*}{$\begin{array}{c}\text { Tipo } \\
\text { de } \\
\text { flor }\end{array}$} & \multicolumn{4}{|c|}{$\begin{array}{l}\text { Lucro bruto unitário } \\
\text { por processo }\end{array}$} & \multicolumn{4}{|c|}{$\begin{array}{c}\text { Lucro líquido unitário } \\
\text { por processo }\end{array}$} \\
\hline & & & & & A & $\mathrm{B}$ & $\mathrm{C}$ & $\mathrm{D}$ & A & $\mathrm{B}$ & $\mathrm{C}$ & $\mathrm{D}$ \\
\hline 9 & 75 & 1,40 & 3,81 & gérb2 & 0,33 & 0,01 & $-0,16$ & 0,38 & 0,33 & $-0,18$ & $-0,46$ & 0,00 \\
\hline 10 & 75 & 1,50 & 1,50 & gérb2 & $-0,06$ & $-0,04$ & $-0,06$ & 0,15 & $-0,06$ & $-0,21$ & $-0,31$ & $-0,14$ \\
\hline 11 & 75 & 1,50 & 2,41 & gérb2 & 0,09 & $-0,02$ & $-0,10$ & 0,24 & 0,09 & $-0,20$ & $-0,37$ & $-0,08$ \\
\hline 12 & 75 & 1,50 & 3,81 & gérb2 & 0,33 & 0,01 & $-0,16$ & 0,38 & 0,33 & $-0,18$ & $-0,46$ & 0,00 \\
\hline 13 & 80 & 1,10 & 1,50 & gérb2 & $-0,06$ & $-0,04$ & $-0,06$ & 0,15 & $-0,06$ & $-0,20$ & $-0,30$ & $-0,13$ \\
\hline 14 & 80 & 1,10 & 2,41 & gérb2 & 0,10 & $-0,02$ & $-0,10$ & 0,24 & 0,10 & $-0,19$ & $-0,36$ & $-0,07$ \\
\hline 15 & 80 & 1,10 & 3,81 & gérb2 & 0,33 & 0,01 & $-0,15$ & 0 , & 0,33 & $-0,17$ & $-0,44$ & 0,02 \\
\hline 16 & 80 & 1,25 & 1,50 & gérb2 & $-0,06$ & $-0,04$ & $-0,06$ & 0,15 & $-0,06$ & $-0,20$ & $-0,30$ & $-0,13$ \\
\hline 17 & 80 & 1,25 & 2,41 & gérb2 & 0,10 & $-0,02$ & $-0,10$ & 0,24 & 0,10 & $-0,19$ & $-0,36$ & $-0,07$ \\
\hline 18 & 80 & 1,25 & 3,81 & gérb2 & 0,33 & 0,01 & $-0,16$ & & 0,33 & & -0 & 0,01 \\
\hline 19 & 80 & 1,40 & 1,50 & gérb2 & $-0,06$ & $-0,04$ & $-0,06$ & 0,1 & $-0,06$ & $-0,20$ & $-0,30$ & $-0,13$ \\
\hline 20 & 80 & 1,40 & 2,41 & gérb2 & 0,10 & $-0,02$ & $-0,10$ & 0,2 & 0,10 & $-0,19$ & $-0,36$ & $-0,07$ \\
\hline 21 & 80 & 1,40 & 3,81 & gérb2 & 0,33 & 0,01 & $-0,16$ & 0,38 & 0,33 & $-0,17$ & $-0,45$ & 0,01 \\
\hline 22 & 80 & 1,50 & 1,50 & gérb2 & $-0,06$ & $-0,04$ & $-0,06$ & 0,15 & $-0,06$ & $-0,20$ & $-0,30$ & $-0,13$ \\
\hline 23 & 80 & 1,50 & & gérb2 & 0,10 & $-0,02$ & $-0,10$ & & 0,10 & $-0,19$ & $-0,36$ & $-0,07$ \\
\hline 24 & 80 & 1,50 & & gér & 0,33 & 0,01 & & & 0,33 & & $-0,45$ & 0,01 \\
\hline 25 & 100 & 1,10 & & gérb2 & $-0,04$ & $-0,04$ & & & $-0,04$ & -0 , & -0, & $-0,10$ \\
\hline 26 & 100 & 1,10 & 2,41 & gérb2 & 0,11 & $-0,02$ & $-0,09$ & 0,25 & 0,11 & $-0,17$ & $-0,34$ & $-0,04$ \\
\hline 27 & 100 & 1,10 & 3,81 & gérb2 & 0,35 & 0,01 & $-0,15$ & 0,39 & 0,35 & $-0,15$ & $-0,42$ & 0,05 \\
\hline 28 & 100 & 1,25 & 1,50 & gérb2 & $-0,04$ & $-0,04$ & $-0,06$ & 0,15 & $-0,04$ & $-0,18$ & $-0,28$ & $-0,10$ \\
\hline 29 & 100 & 1,25 & & gérb2 & 0,11 & $-0,02$ & $-0,10$ & 0,25 & 0,11 & $-0,17$ & $-0,34$ & $-0,04$ \\
\hline 30 & 100 & 1,25 & 3,81 & gérb2 & 0,35 & 0,01 & $-0,15$ & 0,39 & 0,35 & $-0,15$ & $-0,43$ & 0,04 \\
\hline 31 & 100 & 1,40 & 1,50 & gérb2 & $-0,04$ & $-0,04$ & $-0,06$ & 0,15 & $-0,04$ & $-0,18$ & $-0,28$ & $-0,11$ \\
\hline 32 & 100 & 1,40 & 2,41 & gérb2 & 0,11 & $-0,02$ & $-0,10$ & 0,25 & 0,11 & $-0,17$ & $-0,34$ & $-0,05$ \\
\hline 33 & 100 & 1,40 & 3,81 & gérb2 & 0,35 & 0,01 & $-0,16$ & 0,39 & 0,35 & $-0,15$ & $-0,43$ & 0,04 \\
\hline 34 & 100 & 1,50 & 1,50 & gérb2 & $-0,04$ & $-0,04$ & $-0,06$ & 0,15 & $-0,04$ & $-0,18$ & $-0,28$ & $-0,11$ \\
\hline 35 & 100 & 1,50 & 2,41 & gérb2 & 0,11 & $-0,02$ & $-0,10$ & 0,25 & 0,11 & $-0,17$ & $-0,34$ & $-0,05$ \\
\hline 36 & 100 & 1,50 & 3,81 & gérb2 & 0,35 & 0,01 & $-0,16$ & 0,39 & 0,35 & $-0,15$ & $-0,43$ & 0,04 \\
\hline
\end{tabular}


Tabela 18. Principais resultados obtidos das simulações do quinto cenário logístico para cada um dos processos

\begin{tabular}{|c|c|c|c|c|c|c|c|c|c|c|c|c|}
\hline \multirow{2}{*}{$\begin{array}{l}\text { Si- } \\
\text { mu- } \\
\text { la- } \\
\text { ção }\end{array}$} & \multirow{2}{*}{$\begin{array}{c}\text { No. } \\
\text { Has- } \\
\text { tes }\end{array}$} & \multirow{2}{*}{$\begin{array}{c}\text { Fre- } \\
\text { te } \\
\text { Aé- } \\
\text { reo }\end{array}$} & \multirow{2}{*}{$\begin{array}{c}\text { Taxa } \\
\text { Câm- } \\
\text { bio }\end{array}$} & \multirow{2}{*}{$\begin{array}{c}\text { Tipo } \\
\text { de } \\
\text { flor }\end{array}$} & \multicolumn{4}{|c|}{$\begin{array}{l}\text { Lucro bruto unitário } \\
\text { por processo }\end{array}$} & \multicolumn{4}{|c|}{$\begin{array}{c}\text { Lucro líquido unitário } \\
\text { por processo }\end{array}$} \\
\hline & & & & & A & B & $\mathrm{C}$ & D & A & B & $\mathrm{C}$ & $\mathrm{D}$ \\
\hline 1 & 75 & 1,10 & 1,50 & lírio & $-0,34$ & 0,04 & $-0,25$ & 0,38 & $-0,34$ & $-0,78$ & $-1,21$ & $-0,75$ \\
\hline 2 & 75 & 1,10 & 2,41 & lírio & 0,01 & 0,09 & $-0,40$ & 0,62 & 0,01 & $-0,78$ & $-1,45$ & $-0,68$ \\
\hline 3 & 75 & 1,10 & 3,81 & lírio & 0,43 & 0,17 & $-0,63$ & 0,98 & 0,43 & $-0,90$ & $-1,94$ & $-0,70$ \\
\hline 4 & 75 & 1,25 & 1,50 & lírio & $-0,34$ & 0,04 & $-0,25$ & 0,38 & $-0,34$ & $-0,78$ & $-1,21$ & $-0,75$ \\
\hline 5 & 75 & 1,25 & 2,41 & lírio & 0,01 & 0,09 & $-0,40$ & 0,62 & 0,01 & $-0,78$ & $-1,46$ & $-0,69$ \\
\hline 6 & 75 & 1,25 & 3,81 & lírio & 0,43 & 0,17 & $-0,63$ & 0,98 & 0,43 & $-0,90$ & $-1,94$ & $-0,71$ \\
\hline 7 & 75 & 1,40 & 1,50 & lírio & $-0,34$ & 0,04 & $-0,25$ & 0,38 & $-0,34$ & $-0,78$ & $-1,21$ & $-0,75$ \\
\hline 8 & 75 & 1,40 & 2,41 & lírio & 0,01 & 0,09 & $-0,40$ & 0,62 & 0,01 & $-0,78$ & $-1,46$ & $-0,69$ \\
\hline 9 & 75 & 1,40 & 3,81 & lírio & 0,43 & 0,17 & $-0,63$ & 0,98 & 0,43 & $-0,90$ & $-1,95$ & $-0,71$ \\
\hline 10 & 75 & 1,50 & 1,50 & lírio & $-0,34$ & 0,04 & $-0,25$ & 0,38 & $-0,34$ & $-0,78$ & $-1,21$ & $-0,75$ \\
\hline 11 & 75 & 1,50 & 2,41 & lírio & 0,01 & 0,09 & $-0,40$ & 0,62 & 0,01 & $-0,78$ & $-1,46$ & $-0,69$ \\
\hline 12 & 75 & 1,50 & 3,81 & lírio & 0,43 & 0,17 & $-0,64$ & 0,98 & 0,43 & $-0,90$ & $-1,95$ & $-0,71$ \\
\hline 13 & 80 & 1,10 & 1,50 & lírio & $-0,33$ & 0,04 & $-0,24$ & 0,38 & $-0,33$ & $-0,77$ & $-1,19$ & $-0,73$ \\
\hline 14 & 80 & 1,10 & 2,41 & lírio & 0,01 & 0,09 & $-0,39$ & 0,62 & 0,01 & $-0,77$ & $-1,43$ & $-0,66$ \\
\hline 15 & 80 & 1,10 & 3,81 & lírio & 0,44 & 0,17 & $-0,61$ & 0,98 & 0,44 & $-0,89$ & $-1,92$ & $-0,67$ \\
\hline 16 & 80 & 1,25 & 1,50 & lírio & $-0,33$ & 0,04 & $-0,24$ & 0,38 & $-0,33$ & $-0,77$ & $-1,20$ & $-0,73$ \\
\hline 17 & 80 & 1,25 & 2,41 & lírio & 0,01 & 0,09 & $-0,39$ & 0,62 & 0,01 & $-0,77$ & $-1,44$ & $-0,66$ \\
\hline 18 & 80 & 1,25 & 3,81 & lírio & 0,44 & 0,17 & $-0,62$ & 0,98 & 0,44 & $-0,89$ & $-1,92$ & $-0,68$ \\
\hline 19 & 80 & 1,40 & 1,50 & lírio & $-0,33$ & 0,04 & $-0,25$ & 0,38 & $-0,33$ & $-0,77$ & $-1,20$ & $-0,73$ \\
\hline 20 & 80 & 1,40 & 2,41 & lírio & 0,01 & 0,09 & $-0,39$ & 0,62 & 0,01 & $-0,77$ & $-1,44$ & $-0,67$ \\
\hline 21 & 80 & 1,40 & 3,81 & lírio & 0,44 & 0,17 & $-0,62$ & 0,98 & 0,44 & $-0,89$ & $-1,92$ & $-0,68$ \\
\hline 22 & 80 & 1,50 & 1,50 & lírio & $-0,33$ & 0,04 & $-0,25$ & 0,38 & $-0,33$ & $-0,77$ & $-1,20$ & $-0,74$ \\
\hline 23 & 80 & 1,50 & 2,41 & lírio & 0,01 & 0,09 & $-0,39$ & 0,62 & 0,01 & $-0,77$ & $-1,44$ & $-0,67$ \\
\hline 24 & 80 & 1,50 & 3,81 & lírio & 0,44 & 0,17 & $-0,62$ & 0,98 & 0,44 & $-0,89$ & $-1,93$ & $-0,68$ \\
\hline 25 & 100 & 1,10 & 1,50 & lírio & $-0,30$ & 0,04 & $-0,23$ & 0,39 & $-0,30$ & $-0,74$ & $-1,15$ & $-0,68$ \\
\hline 26 & 100 & 1,10 & 2,41 & lírio & 0,04 & 0,09 & $-0,36$ & 0,62 & 0,04 & $-0,74$ & $-1,38$ & $-0,60$ \\
\hline 27 & 100 & 1,10 & 3,81 & lírio & 0,47 & 0,17 & $-0,57$ & 0,99 & 0,47 & $-0,86$ & $-1,84$ & $-0,59$ \\
\hline 28 & 100 & 1,25 & 1,50 & lírio & $-0,30$ & 0,04 & $-0,23$ & 0,39 & $-0,30$ & $-0,74$ & $-1,15$ & $-0,68$ \\
\hline 29 & 100 & 1,25 & 2,41 & lírio & 0,04 & 0,09 & $-0,36$ & 0,62 & 0,04 & $-0,74$ & $-1,38$ & $-0,60$ \\
\hline 30 & 100 & 1,25 & 3,81 & lírio & 0,47 & 0,17 & $-0,57$ & 0,99 & 0,47 & $-0,86$ & $-1,85$ & $-0,59$ \\
\hline 31 & 100 & 1,40 & 1,50 & lírio & $-0,30$ & 0,04 & $-0,23$ & 0,39 & $-0,30$ & $-0,74$ & $-1,15$ & $-0,68$ \\
\hline 32 & 100 & 1,40 & 2,41 & lírio & 0,04 & 0,09 & $-0,37$ & 0,62 & 0,04 & $-0,74$ & $-1,38$ & $-0,60$ \\
\hline 33 & 100 & 1,40 & 3,81 & lírio & 0,47 & 0,17 & $-0,58$ & 0,99 & 0,47 & $-0,86$ & $-1,85$ & $-0,60$ \\
\hline 34 & 100 & 1,50 & 1,50 & lírio & $-0,30$ & 0,04 & $-0,23$ & 0,39 & $-0,30$ & $-0,74$ & $-1,15$ & $-0,68$ \\
\hline 35 & 100 & 1,50 & 2,41 & lírio & 0,04 & 0,09 & $-0,37$ & 0,62 & 0,04 & $-0,74$ & $-1,38$ & $-0,60$ \\
\hline 36 & 100 & 1,50 & 3,81 & lírio & 0,47 & 0,17 & $-0,58$ & 0,99 & 0,47 & $-0,86$ & $-1,85$ & $-0,60$ \\
\hline 1 & 75 & 1,10 & 1,50 & gérb1 & $-0,32$ & $-0,16$ & $-0,20$ & 0,18 & $-0,32$ & $-0,79$ & $-1,06$ & $-0,86$ \\
\hline 2 & 75 & 1,10 & 2,41 & gérb1 & $-0,13$ & $-0,13$ & $-0,32$ & 0,30 & $-0,13$ & $-0,78$ & $-1,21$ & $-0,86$ \\
\hline 3 & 75 & 1,10 & 3,81 & gérb1 & 0,16 & $-0,10$ & $-0,50$ & 0,48 & 0,16 & $-0,78$ & $-1,46$ & $-0,87$ \\
\hline 4 & 75 & 1,25 & 1,50 & gérb1 & $-0,32$ & $-0,16$ & $-0,20$ & 0,18 & $-0,32$ & $-0,79$ & $-1,06$ & $-0,86$ \\
\hline
\end{tabular}


Tabela 18. Principais resultados obtidos das simulações do quinto cenário logístico para cada um dos processos

\begin{tabular}{|c|c|c|c|c|c|c|c|c|c|c|c|c|}
\hline \multirow{2}{*}{$\begin{array}{c}\text { Si- } \\
\text { mu- } \\
\text { la- } \\
\text { ção }\end{array}$} & \multirow{2}{*}{$\begin{array}{c}\text { No. } \\
\text { Has- } \\
\text { tes }\end{array}$} & \multirow{2}{*}{$\begin{array}{c}\text { Fre- } \\
\text { te } \\
\text { Aé- } \\
\text { reo }\end{array}$} & \multirow{2}{*}{$\begin{array}{c}\text { Taxa } \\
\text { Câm- } \\
\text { bio } \\
\end{array}$} & \multirow{2}{*}{$\begin{array}{c}\text { Tipo } \\
\text { de } \\
\text { flor }\end{array}$} & \multicolumn{4}{|c|}{$\begin{array}{l}\text { Lucro bruto unitário } \\
\text { por processo }\end{array}$} & \multicolumn{4}{|c|}{$\begin{array}{c}\text { Lucro líquido unitário } \\
\text { por processo }\end{array}$} \\
\hline & & & & & A & B & $\mathrm{C}$ & D & A & B & $\mathrm{C}$ & $\mathrm{D}$ \\
\hline 5 & 75 & 1,25 & 2,41 & gérb1 & $-0,13$ & $-0,13$ & $-0,32$ & 0,30 & $-0,13$ & $-0,78$ & $-1,22$ & $-0,86$ \\
\hline 6 & 75 & 1,25 & 3,81 & gérb1 & 0,16 & $-0,10$ & $-0,50$ & 0,48 & 0,16 & $-0,78$ & $-1,47$ & $-0,87$ \\
\hline 7 & 75 & 1,40 & 1,50 & gérb1 & $-0,32$ & $-0,16$ & $-0,20$ & 0,18 & $-0,32$ & $-0,79$ & $-1,06$ & $-0,86$ \\
\hline 8 & 75 & 1,40 & 2,41 & gérb1 & $-0,13$ & $-0,13$ & $-0,32$ & 0,30 & $-0,13$ & $-0,78$ & $-1,22$ & $-0,87$ \\
\hline 9 & 75 & 1,40 & 3,81 & gérb1 & 0,16 & $-0,10$ & $-0,51$ & 0,48 & 0,16 & $-0,78$ & $-1,47$ & $-0,88$ \\
\hline 10 & 75 & 1,50 & 1,50 & gérb1 & $-0,32$ & $-0,16$ & $-0,20$ & 0,18 & $-0,32$ & $-0,79$ & $-1,06$ & $-0,87$ \\
\hline 11 & 75 & 1,50 & 2,41 & gérb1 & $-0,13$ & $-0,13$ & $-0,32$ & 0,30 & $-0,13$ & $-0,78$ & $-1,22$ & $-0,87$ \\
\hline 12 & 75 & 1,50 & 3,81 & gérb1 & 0,16 & $-0,10$ & $-0,51$ & 0,48 & 0,16 & $-0,78$ & $-1,47$ & $-0,88$ \\
\hline 13 & 80 & 1,10 & 1,50 & gérb1 & $-0,32$ & $-0,16$ & $-0,20$ & 0,18 & $-0,32$ & $-0,78$ & $-1,05$ & $-0,85$ \\
\hline 14 & 80 & 1,10 & 2,41 & gérb1 & $-0,13$ & $-0,13$ & $-0,31$ & 0,30 & $-0,13$ & $-0,78$ & $-1,20$ & $-0,84$ \\
\hline 15 & 80 & 1,10 & 3,81 & gérb1 & 0,16 & $-0,10$ & $-0,48$ & 0,48 & 0,16 & $-0,78$ & $-1,44$ & $-0,85$ \\
\hline 16 & 80 & 1,25 & 1,50 & gérb1 & $-0,32$ & $-0,16$ & $-0,20$ & 0,18 & $-0,32$ & $-0,78$ & $-1,05$ & $-0,85$ \\
\hline 17 & 80 & 1,25 & 2,41 & gérb1 & $-0,13$ & $-0,13$ & $-0,31$ & 0,30 & $-0,13$ & $-0,78$ & $-1,20$ & $-0,85$ \\
\hline 18 & 80 & 1,25 & 3,81 & gérb1 & 0,16 & $-0,10$ & $-0,49$ & 0,48 & 0,16 & $-0,78$ & $-1,45$ & $-0,85$ \\
\hline 19 & 80 & 1,40 & 1,50 & gérb1 & $-0,32$ & $-0,16$ & $-0,20$ & 0,18 & $-0,32$ & $-0,78$ & $-1,05$ & $-0,85$ \\
\hline 20 & 80 & 1,40 & 2,41 & gérb1 & $-0,13$ & $-0,13$ & $-0,31$ & 0,30 & $-0,13$ & $-0,78$ & $-1,21$ & $-0,85$ \\
\hline 21 & 80 & 1,40 & 3,81 & gérb1 & 0,16 & $-0,10$ & $-0,49$ & 0,48 & 0,16 & $-0,78$ & $-1,45$ & $-0,85$ \\
\hline 22 & 80 & 1,50 & 1,50 & gérb1 & $-0,32$ & $-0,16$ & $-0,20$ & 0,18 & $-0,32$ & $-0,78$ & $-1,05$ & $-0,85$ \\
\hline 23 & 80 & 1,50 & 2,41 & gérb1 & $-0,13$ & $-0,13$ & $-0,32$ & 0,30 & $-0,13$ & $-0,78$ & $-1,21$ & $-0,85$ \\
\hline 24 & 80 & 1,50 & 3,81 & gérb1 & 0,16 & $-0,10$ & $-0,49$ & 0,48 & 0,16 & $-0,78$ & $-1,45$ & $-0,86$ \\
\hline 25 & 100 & 1,10 & 1,50 & gérb1 & $-0,30$ & $-0,16$ & $-0,18$ & 0,18 & $-0,30$ & $-0,77$ & $-1,01$ & $-0,81$ \\
\hline 26 & 100 & 1,10 & 2,41 & gérb1 & $-0,11$ & $-0,13$ & $-0,28$ & 0,31 & $-0,11$ & $-0,77$ & $-1,16$ & $-0,79$ \\
\hline 27 & 100 & 1,10 & 3,81 & gérb1 & 0,18 & $-0,10$ & $-0,44$ & 0,49 & 0,18 & $-0,76$ & $-1,39$ & $-0,78$ \\
\hline 28 & 100 & 1,25 & 1,50 & gérb1 & $-0,30$ & $-0,16$ & $-0,18$ & 0,18 & $-0,30$ & $-0,77$ & $-1,02$ & $-0,81$ \\
\hline 29 & 100 & 1,25 & 2,41 & gérb1 & $-0,11$ & $-0,13$ & $-0,29$ & 0,31 & $-0,11$ & $-0,77$ & $-1,16$ & $-0,80$ \\
\hline 30 & 100 & 1,25 & 3,81 & gérb1 & 0,18 & $-0,10$ & $-0,45$ & 0,49 & 0,18 & $-0,76$ & $-1,39$ & $-0,78$ \\
\hline 31 & 100 & 1,40 & 1,50 & gérb1 & $-0,30$ & $-0,16$ & $-0,18$ & 0,18 & $-0,30$ & $-0,77$ & $-1,02$ & $-0,81$ \\
\hline 32 & 100 & 1,40 & 2,41 & gérb1 & $-0,11$ & $-0,13$ & $-0,29$ & 0,31 & $-0,11$ & $-0,77$ & $-1,16$ & $-0,80$ \\
\hline 33 & 100 & 1,40 & 3,81 & gérb1 & 0,18 & $-0,10$ & $-0,45$ & 0,49 & 0,18 & $-0,76$ & $-1,39$ & $-0,79$ \\
\hline 34 & 100 & 1,50 & 1,50 & gérb1 & $-0,30$ & $-0,16$ & $-0,18$ & 0,18 & $-0,30$ & $-0,77$ & $-1,02$ & $-0,82$ \\
\hline 35 & 100 & 1,50 & 2,41 & gérb1 & $-0,11$ & $-0,13$ & $-0,29$ & 0,31 & $-0,11$ & $-0,77$ & $-1,17$ & $-0,80$ \\
\hline 36 & 100 & 1,50 & 3,81 & gérb1 & 0,18 & $-0,10$ & $-0,45$ & 0,49 & 0,18 & $-0,76$ & $-1,40$ & $-0,79$ \\
\hline 1 & 75 & 1,10 & 1,50 & gérb2 & $-0,05$ & $-0,02$ & $-0,16$ & 0,14 & $-0,05$ & $-0,18$ & $-0,40$ & $-0,22$ \\
\hline 2 & 75 & 1,10 & 2,41 & gérb2 & 0,11 & 0,00 & $-0,26$ & 0,22 & 0,11 & $-0,16$ & $-0,51$ & $-0,22$ \\
\hline 3 & 75 & 1,10 & 3,81 & gérb2 & 0,35 & 0,03 & $-0,41$ & 0,36 & 0,35 & $-0,14$ & $-0,69$ & $-0,23$ \\
\hline 4 & 75 & 1,25 & 1,50 & gérb2 & $-0,05$ & $-0,02$ & $-0,17$ & 0,14 & $-0,05$ & $-0,18$ & $-0,40$ & $-0,22$ \\
\hline 5 & 75 & 1,25 & 2,41 & gérb2 & 0,11 & 0,00 & $-0,26$ & 0,22 & 0,11 & $-0,16$ & $-0,51$ & $-0,23$ \\
\hline 6 & 75 & 1,25 & 3,81 & gérb2 & 0,35 & 0,03 & $-0,42$ & 0,36 & 0,35 & $-0,14$ & $-0,70$ & $-0,23$ \\
\hline 7 & 75 & 1,40 & 1,50 & gérb2 & $-0,05$ & $-0,02$ & $-0,17$ & 0,14 & $-0,05$ & $-0,18$ & $-0,40$ & $-0,23$ \\
\hline 8 & 75 & 1,40 & 2,41 & gérb2 & 0,11 & 0,00 & $-0,27$ & 0,22 & 0,11 & $-0,16$ & $-0,52$ & $-0,23$ \\
\hline
\end{tabular}


Tabela 18. Principais resultados obtidos das simulações do quinto cenário logístico para cada um dos processos

\begin{tabular}{|c|c|c|c|c|c|c|c|c|c|c|c|c|}
\hline \multirow{2}{*}{$\begin{array}{l}\text { Si- } \\
\text { mu- } \\
\text { la- } \\
\text { ção }\end{array}$} & \multirow{2}{*}{$\begin{array}{c}\text { No. } \\
\text { Has- } \\
\text { tes }\end{array}$} & \multirow{2}{*}{$\begin{array}{c}\text { Fre- } \\
\text { te } \\
\text { Aé- } \\
\text { reo }\end{array}$} & \multirow{2}{*}{$\begin{array}{c}\text { Taxa } \\
\text { Câm- } \\
\text { bio }\end{array}$} & \multirow{2}{*}{$\begin{array}{c}\text { Tipo } \\
\text { de } \\
\text { flor }\end{array}$} & \multicolumn{4}{|c|}{$\begin{array}{l}\text { Lucro bruto unitário } \\
\text { por processo }\end{array}$} & \multicolumn{4}{|c|}{$\begin{array}{c}\text { Lucro líquido unitário } \\
\text { por processo }\end{array}$} \\
\hline & & & & & A & $\mathrm{B}$ & $\mathrm{C}$ & $\mathrm{D}$ & A & $\mathrm{B}$ & $\mathrm{C}$ & $\mathrm{D}$ \\
\hline 9 & 75 & 1,40 & 3,81 & gérb2 & 0,35 & 0,03 & $-0,42$ & 0,36 & 0,35 & $-0,14$ & $-0,70$ & $-0,23$ \\
\hline 10 & 75 & 1,50 & 1,50 & gérb2 & $-0,05$ & $-0,02$ & $-0,17$ &, 14 & $-0,05$ & $-0,18$ & $-0,40$ & $-0,23$ \\
\hline 11 & 75 & 1,50 & 2,41 & gérb2 & 0,11 & 0,00 & $-0,27$ & 0,22 & 0,11 & $-0,16$ & $-0,52$ & $-0,23$ \\
\hline 12 & 75 & 1,50 & 3,81 & gérb2 & 0,35 & 0,03 & $-0,42$ & 0,36 & 0,35 & $-0,14$ & $-0,70$ & $-0,24$ \\
\hline 13 & 80 & 1,10 & 1,50 & gérb2 & $-0,04$ & $-0,02$ & $-0,16$ & 0,14 & $-0,04$ & $-0,17$ & $-0,38$ & $-0,21$ \\
\hline 14 & 80 & 1,10 & 2,41 & gérb2 & 0,11 & 0,00 & $-0,25$ & 0,23 & 0,11 & $-0,16$ & $-0,50$ & $-0,21$ \\
\hline 15 & 80 & 1,10 & 3,81 & gérb2 & 0,35 & 0,03 & $-0,40$ & 0,36 & 0,35 & $-0,13$ & $-0,67$ & $-0,20$ \\
\hline 16 & 80 & 1,25 & 1,50 & gérb2 & $-0,04$ & $-0,02$ & $-0,16$ & 0,14 & $-0,04$ & $-0,17$ & $-0,39$ & $-0,21$ \\
\hline 17 & 80 & 1,25 & 2,41 & gérb2 & 0,11 & 0,00 & $-0,26$ & 0,23 & 0,11 & $-0,16$ & $-0,50$ & $-0,21$ \\
\hline 18 & 80 & 1,25 & 3,81 & gérb2 & 0,35 & 0,03 & -0 , & & 0,35 & & $-0,6$ & $-0,21$ \\
\hline 19 & 80 & 1,40 & 1,50 & gérb2 & $-0,04$ & $-0,02$ & $-0,16$ & 0,14 & $-0,04$ & $-0,17$ & $-0,39$ & $-0,21$ \\
\hline 20 & 80 & 1,40 & 2,41 & gérb2 & 0,11 & 0,00 & $-0,26$ & 0,23 & 0,11 & $-0,16$ & $-0,50$ & $-0,21$ \\
\hline 21 & 80 & 1,40 & 3,81 & gérb2 & 0,35 & 0,03 & $-0,41$ & 0,36 & 0,35 & $-0,13$ & $-0,68$ & $-0,21$ \\
\hline 22 & 80 & 1,50 & 1,50 & gérb2 & $-0,04$ & $-0,02$ & $-0,16$ & 0,14 & $-0,04$ & $-0,17$ & $-0,39$ & $-0,21$ \\
\hline 23 & 80 & 1,50 & & gérb2 & 0,11 & 0,00 & $-0,26$ & & 0,11 & $-0,16$ & $-0,50$ & $-0,21$ \\
\hline 24 & 80 & 1,50 & & gér & 0 , & 0,03 & & & 0,35 & -0 , & -0, & $-0,21$ \\
\hline 25 & 100 & 1,10 & & gérb2 & $-0,03$ & $-0,02$ & & & $-0,03$ & & -0 & $-0,17$ \\
\hline 26 & 100 & 1,10 & 2,41 & gérb2 & 0,13 & 0,00 & $-0,23$ & 0,23 & 0,13 & $-0,14$ & $-0,46$ & $-0,15$ \\
\hline 27 & 100 & 1,10 & 3,81 & gérb2 & 0,37 & 0,03 & $-0,36$ & 0,37 & 0,37 & $-0,12$ & $-0,62$ & $-0,13$ \\
\hline 28 & 100 & 1,25 & 1,50 & gérb2 & $-0,03$ & $-0,02$ & $-0,14$ & 0,14 & $-0,03$ & $-0,16$ & $-0,35$ & $-0,17$ \\
\hline 29 & 100 & 1,25 & & gérb2 & 0,13 & 0,00 & $-0,23$ & 0,23 & 0,13 & $-0,14$ & $-0,46$ & $-0,16$ \\
\hline 30 & 100 & 1,25 & 3,81 & gérb2 & 0,37 & 0,03 & $-0,36$ & 0,37 & 0,37 & $-0,12$ & $-0,62$ & $-0,14$ \\
\hline 31 & 100 & 1,40 & 1,50 & gérb2 & $-0,03$ & $-0,02$ & $-0,15$ & 0,14 & $-0,03$ & $-0,16$ & $-0,35$ & $-0,17$ \\
\hline 32 & 100 & 1,40 & 2,41 & gérb2 & 0,13 & 0,00 & $-0,23$ & 0,23 & 0,13 & $-0,14$ & $-0,46$ & $-0,16$ \\
\hline 33 & 100 & 1,40 & 3,81 & gérb2 & 0,37 & 0,03 & $-0,37$ & 0,37 & 0,37 & $-0,12$ & $-0,62$ & $-0,14$ \\
\hline 34 & 100 & 1,50 & 1,50 & gérb2 & $-0,03$ & $-0,02$ & $-0,15$ & 0,14 & $-0,03$ & $-0,16$ & $-0,36$ & $-0,18$ \\
\hline 35 & 100 & 1,50 & 2,41 & gérb2 & 0,13 & 0,00 & $-0,23$ & 0,23 & 0,13 & $-0,14$ & $-0,46$ & $-0,16$ \\
\hline 36 & 100 & 1,50 & 3,81 & gérb2 & 0,37 & 0,03 & $-0,37$ & 0,37 & 0,37 & $-0,12$ & $-0,63$ & $-0,14$ \\
\hline
\end{tabular}




\section{REFERÊNCIAS BIBLIOGRÁFICAS}

AKI, A. Sobre o novo comportamento para os diversos agentes da cadeia de flores em um mercado de oferta. Revista Brasileira de Horticultura Ornamental, v.3, n.1, p.8-12, 1997.

ALBINO, V.; IZZO, C.; KÜHTZ, S. Input-output models for the analysis of a local/global supply chain. International Journal of Production Economics, v.78, n.2, p.119-131, 2002.

ALMEIDA, L.G. Gerência de processo: mais um passo para a excelência. Rio de Janeiro: Qualitymark E., 1993. 125p.

ANEFALOS, L.C.; GUILHOTO, J.M. Estrutura do mercado brasileiro de flores e plantas ornamentais. Agricultura em São Paulo, v.50, n.2, p.41-63, 2003.

ALVES, T. Flores brasileiras batem recorde de exportação. O Estado de São Paulo. Negócios \& Oportunidades, São Paulo, 01 fev. 2004. p.1.

BANCO CENTRAL DO BRASIL. Câmbio e capitais estrangeiros. http:// www.bcb.gov.br (13 mar. 2004)

BARLETTA, A. Shipping flowers via air. FloraCulture International, v.5, n.3, p.1795, Mar. 1995.

BEAMON, B.M. Supply chain design and analysis: models and methods. International Journal of Production Economics, v.55, n.3, p.281-294, 1998.

BLANCO, R.A. Jardim de flores: gérbera, 12 set. 2001. http://www.jardimdeflores.com.br/floresefolhas/A08gerbera.htm (28 jun. 2004)

BOERSEN, A. Bulbos de flores naturais. Holambra, 2001. 
BONGERS, F.J.G. O desenvolvimento da floricultura no Brasil. IBRAFLOR Informativo, v.5, n.19, maio 2000. http://www.flortec.com.br/ artigo04.htm (19 ago. 2001)

BOWERSOX, D.J.; CLOSS, D.J. Logistical management: the integrated supply chain process. New York: McGraw-Hill, 1996. 730p.

BRASIL. Secretaria de Comércio Exterior (SECEX). Exportação e importação brasileira de plantas vivas e produtos de floricultura: 1989-2003. Brasília, 2004. http://aliceweb.\%20mdic.gov.br/consulta_nova/resultadoConsulta.asp $\quad(16 \mathrm{fev}$. 2004)

BRITISH COLUMBIA. An overview of the BC floriculture industry. Abbotsford: Fact Sheet, Oct. 2003. http://www.agf.gov.bc.ca/ornamentals/ publications/documents/overview/floriculture/2003oct28.pdf (18 Feb. 2004)

BRUMFIELD, R.G. Economic and marketing issues from a grower's perspective. Agricultural Outlook Fórum 2003. Arlington, 2003. p.1-11.

CAIXETA-FILHO, J.V.; SWAAY-NETO, J.M. van; LOPES, L.L. Linear programming applied to the flower sector: a gladiolus bulb production case study. International Transactions in Operational Research, v.7, n.6, p.525-37, 2000.

CAIXETA-FILHO, J.V.; SWAAY-NETO, J.M. van; WAGEMAKER, A.P. Optimization of the production planning and trade of lily flowers at Jan de Wit Company. Interfaces, v.32, n.1, p.35-46, 2002.

CALÇADOS e flores. Panorama Brasil, 03 jun. 2002. http://home.linkway.com.br/ noticia.jsp?idnoticia $=3730$ ( 17 jul. 2002)

CASTRO, J.A. Exportação: aspectos práticos e operacionais. São Paulo: Aduaneiras, 2003. 322p.

CENTRE FOR THE PROMOTION OF IMPORTS FROM DEVELOPING COUNTRIES. EU Market Survey 2002: cut flowers and foliage. Rotterdam: CBI, Oct. 2002. 87p. http://212.133.165.5/dokumanlar/dtc/ulke_rehberleri/ pdf/survey_cut_flowers_2002.pdf(26 May 2004) 
CENTRE FOR THE PROMOTION OF IMPORTS FROM DEVELOPING COUNTRIES. EU Market Survey 2003 cut flowers and foliage. Rotterdam: CBI, Oct. 2003. 122p. http://www.prompex.gob.pe/prompex/InformeMercados/ PDF/CBI/Market\%20Survey/survey_cut_flowers_2003.pdf (26 May 2004)

CHOPRA, S.; MEINDL, P. Supply chain management: strategy, planning and operation. New Jersey: Prentice Hall, 2001. 457p.

CLARO, D.P. Análise do complexo agroindustrial das flores do Brasil. Lavras, 1998. 103p. Dissertação (M.S.) - Universidade Federal de Lavras.

CONFEDERAÇÃO NACIONAL DA INDÚSTRIA. Os problemas da empresa exportadora brasileira. Brasília, 2002. http://www.cni.org.br/f-ps-empresaexportadora-brasileira.pdf (02 jun. 2004)

COOPER, M.; LAMBERT, D.; PAGH, J. Supply chain management: more than a new for logistics. International Journal of Logistics Management, v.8, n.1, p.1-13, 1997.

COUTO, M. Vida longa às flores. Revista Abrava, v.26, n.196, set. 2002 . http://www.portalabrava.com.br/news/revista/ler_196.asp (19 fev. 2003)

DAVENPORT, T.H. Reengenharia de processos: como inovar na empresa através da tecnologia da informação. Trad. de Waltensir Dutra. Rio de Janeiro: Campus, 1994. $391 \mathrm{p}$.

DEMARCHI, C. Guerra das flores movimenta os trópicos. Gazeta Mercantil LatinoAmericana, 28 fev./04 mar. 2001. p.7-8.

DONOVAN, R.M. Supply chain management: cracking the bullwhip effect - Part. III.

$\begin{array}{llllll}\text { ITtoolbox } & \text { Supply } & \text { Chain. } & 18 & \text { Feb. } & 2002 .\end{array}$ http://www.supplychain.ittoolbox.com.br/rdo21202b.pdf (26 Feb. 2004)

DORNIER, P.; ERNST, R.; FENDER, M.; KOUVELIS, P. Logística e operações globais: texto e casos. Trad. de A. I. Utiyama. São Paulo: Atlas, 2000. 721p.

EDGEMAN, R.L. Diagnosing TQM by International Quality Prize Criteria \& Benchmarking: benchmarking ideas, definitions \& code of conduct. Arhus: Department of Information Science, 31 Dec. 1998. http://lamar.colostate.edu/ $\sim$ redgeman/ benchmarking/Benchmarking.ppt (23 Oct. 2002) 
ELSHOF, P. The dutch flower sector: structure, trends and employment. Geneva: International Labour Organization (ILO), Food Research and Consultancy, 1998. http://www.ilo.org/public/english/dialogue/ sector/papers/flrsect/flrsect5.htm (17 Apr. 2004)

ENGELBART, F.W.G.A.; RIJSWIJK, L.W. Business case description: Plantania. SHertongenbosch: ABN AMRO-ACC, 31 ago. 2001a. 28p. http://www.kcacc.org/pdf/plantania.pdf (29 May 2004)

ENGELBART, F.W.G.A.; RIJSWIJK, L.W. Business case description: shortened fresh collection. S-Hertongenbosch: ABN AMRO-ACC, 07 set. 2001b. 26p. http://www.klict.org/docs/BCop048.pdf (30 Mar. 2003)

FAILS, B.; CARLSON, W. Floriculture. East Lansing: MSU Extension, 28 July 1998 (Ag Experiment Station Special Reports, SR639201) http://www.msue.msu.edu/ msue/imp/modsr/sr639201.html (23 Nov. 2003)

FAWCETT, S.E.; CLINTON, S.R. Enhancing logistics performance to improve the competitiveness of manufacturing organizations. Production and Inventory Management Journal, v.37, n.1, p.40-46, 1996.

FERREIRA, L.A.F. Transporte aéreo internacional: características, custos e visão estratégica de logística. São Paulo: Aduaneiras, 2003. 132p.

FISHER, M. What is the right supply chain for your product? Harvard Business Review, v.75, n.2, p.105-116, Mar./Apr. 1997.

FLORABRASILIS. Relatório do diagnóstico da produção de flores e plantas ornamentais brasileira (compact disc). Campinas: IBRAFLOR, 2002.

FLORES e plantas ornamentais. Agronegócios. Campinas, 2001. http://www1.bb.com.br/por_noticias_publicacoes/rce_pubRCEfichaartigo (26 ago. 2001)

FLORICULTURE AND NURSERY CROPS SITUATION AND OUTLOOK YEARBOOK. Washington: USDA, May 2002. 107p.

FLORICULTURE AND NURSERY CROPS SITUATION AND OUTLOOK YEARBOOK. Washington: USDA, Sep. 2003. 24p. http://www.ers.usda.gov/publications/flo_sep03/ flo02.pdf (24 Nov. 2003) 
FLOWER COUNCIL OF HOLLAND. Flower Council. http://www.flowercouncil.org (02 Feb. 2002)

FNP CONSULTORIA \& COMÉRCIO. Agrianual 2001: anuário da agricultura brasileira. São Paulo, 2001. p.337-348: Flores.

FRANCO, F.A.L.; SANTANA, P.M.; ALMEIDA, C.B.; BRAGA, R.J. Recent deregulation of the air transportation in Brazil. Brasília: Ministério da Fazenda da Secretaria de Planejamento Econômico, jan. 2002. http://www.fazenda.gov.br/seae_documentos_doctrabalho/DocTrab12.pdf (14 jul. 2003)

GARVIN, D.A. Leveraging processes for strategic advantage. Harvard Business Review, v.73, n.5, p.77-90, Sep./Oct. 1995.

GOÉS, V.L de. A comercialização internacional de flores e a formação de preço. São Paulo, 1997. 143p. Dissertação (Mestrado) - Escola de Administração de Empresas de São Paulo, Fundação Getúlio Vargas.

GOLLNOW, B. Exporting cut flowers. NSW Agriculture. Orange, 2002. http://www.agric.nsw.gov.au/reader/ornamentals/export-flowers.htm $\quad(21$ Nov. 2003)

GOOLEY, T.B. Airfreight packaging: don't take it lightly! Logistics Management, v.43, n.4, p.49-54, Apr. 2004. http://www.logisticsmgmt.com (20 May 2004)

HARMONIZED tariff schedule of the United States. http://hotdocs.usitc.gov/ tariff_chapters_current/0400C06.pdf (07 Apr. 2004)

HENKOFF, R. Delivering the goods. Fortune, v.130, n.11, p.64-78, Nov. 1994.

HUGHES, A. Retailers, knowledges and changing commodity networks: the case of the cut flower trade. Geoforum, v.31, n.2, p.175-190, 2000.

INFRAERO. Infraero constata mudança no perfil da carga exportada. Net Marinha, 08 abr. 2003. http://www.marinhamercante.com.br/setores.asp (23 nov. 2003)

INSTITUTO BRASILEIRO DE FLORICULTURA (IBRAFLOR). Padrão IBRAFLOR de qualidade. Campinas, 2000. 87p. 
KAHN, K.; MENTZER, J.T. Logistics and interdepartmental integration. International Journal of Physical Distribution \& Logistics Management, v.26, n.8, p.6-14, 1996.

KEEDI, S.; MENDONÇA, P.C.C. de. Transportes e seguros no comércio exterior. São Paulo: Aduaneiras, 2000. 254p.

KESSLER JUNIOR, J.R. Greenhouse production of gerbera daisies. Alabama cooperative extension system: ANR-1144. Auburn: Auburn University, Feb. 1999. 6p. http://www.aces.edu/pubs/docs/A/ANR-1144.ANR-1144.pdf (01 July 2004)

KIYUNA, I.; COELHO, P.C.; ÂNGELO, J.A.; ASSUMPÇÃO, R. de. Parceiros comerciais internacionais da floricultura brasileira, 1989 a 2002. Informações Econômicas, v.34, n.5, p.7-34, maio 2004.

KLEIN, S.; FRAZIER, G.L.; ROTH, V.J. A transaction cost analysis model of channel integration in international markets. Journal of Marketing Research, v.27, n.2, p.196-208, 1990.

LEE, H.L.; PADMANABHAM, V.; WHANG, S. The bullwhip effect in supply chains. Sloan Management Review, v.38, n.3, p.93-103, Apr. 1997.

LÍDERES mundiais de sementes e mudas de flores selam parceria. http://www.becapi.com.br/noticias/vanzantem.html (20 jun. 2001)

LIEMT, G. van. The world cut flower industry: trends and prospects (1999). Geneva: International Labour Organization (ILO), 2000. (Working paper) http://www.ilo.org/public/english/dialogue/sector/papers/ctflower/139e1.htm (06 Oct. 2003)

LIM, A.; TAM, S.C. The airfreight cold chain of cut flowers from western Australia and future possibilities. Floriculture News, n.54, Aug. 2001. http://www.agric.wa.gov.au/programs/hort/floriculture/newsletter/Issue54_54p.htm (21 Nov. 2003)

LIN, X.; POLENSKE, K.R. Input-output modeling of production processes for business management. Structural Change and Economic Dynamics, v.9, n.2, p.205-226, 1998. 
LOPEZ, C. Os custos logísticos do comércio exterior. São Paulo: Aduaneiras, 2000. $136 \mathrm{p}$.

LUCAS, K. Em busca do "selo verde". http://www.tierramerica.net/2001/0603/ pacentos.shtml (06 mar. 2001)

LUMMUS, R.R.; VOKURKA, R.J. Defining supply chain management: a historical perspective and practical guidelines. Industrial Management \& Data Systems, v.99, n.1, p.11-17, 1999.

MACHADO, R.T.M. Rastreabilidade, tecnologia da informação e coordenação de sistemas agroindustriais. São Paulo, 2000. 239p. Tese (Doutorado) - Faculdade de Economia, Administração e Contabilidade, Universidade de São Paulo.

McGAUGHEY, R.E. Jr.; SNYDER, C.A.; CARR, H.H. Implementing information technology for competitive advantage: risk management issues. Information \& Management, v.26, n.5, p.273-280, 1994.

MILLER, M.N. Opportunities and challenges for floricultural producers selling to a changing marketplace. Agricultural Outlook Fórum 2003. Arlington:USDA, 2003. p.1-5.

MILLER, R.E.; BLAIR, P.D. Input-output analysis: foundations and extensions. Englewood Cliffs: Prentice-Hall, 1985. 464p.

MIN, H.; ZHOU, G. Supply chain modeling: past, present and future. Computers \& Industrial Engineering, v.43, n.2, p.231-249, 2002.

MOTOS, J. Padrão IBRAFLOR de qualidade. IBRAFLOR Informativo, v.5, n.20, 1999. http://www.flortec.com.br/ artigo02.htm (19 ago. 2001)

MOTOS, J. A importância dos materiais de propagação na qualidade das flores e plantas. IBRAFLOR Informativo, v.6, n.21, jan. 2000a. http://www.flortec.com.br/ artigo05.htm (19 ago. 2001)

MOTOS, J. A produção de flores e plantas ornamentais no Brasil e no mundo. Flores de Corte, dez. 2000b. http://www.flortec.com.br/artigo10.htm (19 ago. 2001)

NOVAES, A.G. Logística, globalização e agribusiness. /Apresentado ao 1. Fórum de Discussão em Logística, Piracicaba, 2002/ 
OKUDA, T. Mercado de flores tem grande potencial no país. Frutas e Legumes, v.1, n.3, p.22-26, 2000.

OLIVEIRA, M.J. de. Logística na pós-colheita de rosas. Revista Brasileira de Horticultura Ornamental, v.1, n.2, p.101-107, 1995.

PATHFAST. International floriculture trade statistics. Erwarton, 2001. http://www.pathfastpublishing.com/ITS20/ITS21 (15 Mar. 2004)

POLENSKE, K.R. Competitive advantage of regional internal and external supply chains. In: LAHR, M.L.; MILLER, R.E. Regional science perspectives in economic analysis: a festschrift in memory of Benjamin H. Stevens. Amsterdam: Elsevier Science, 2001. p.261-286.

POLENSKE, K.R.; McMICHAEL, F.C. A chinese cokemaking process-flow model for energy and environmental analyses. Energy Policy, v.30, n.2, p.865-883, 2002.

PORTER, M.E. Competitive advantage: creating and sustaining superior perfomance. New York: Free, 1985. 557p.

PORTER, M.E. What is strategy? Harvard Business Review, v.74, n.6, p.61-78, Nov./Dec. 1996.

PROBLEMAS E SOLUÇÕES: só falta ação. O Estado de São Paulo. São Paulo, 08 out. 2000. Suplemento. http://www.jt.estadao.com.br/suplementos/ domi/2000/10/08/ domi010.html (20 out. 2003)

PRONK, T. Greve prejudica exportação de flores. BECAPI, 18 jun. 2000. http://www.becapi.com.br/noticias/exporta.html (17 jul. 2002)

ROSAS e espécies tropicais atraem compradores nos EUA e na Europa. Revista Update, n.363, ago. 2000. http://www.amcham.com.br/revista/363/exportacao.html (27 set. 2001)

SÁ, C.D.; CLARO, D.P.; CAIXETA-FILHO, J.V. Logística e transporte aéreo na cadeia de flores de corte: um estudo de caso holandês. Caderno de Pesquisas em Administração, v.11, n.2, p.45-60, abr./jun. 2004.

SALIN, V.; NAYGA JUNIOR, R.M. A cold chain network for food exports to developing countries. International Journal of Physical Distribution \& Logistics Management, v.33, n.10, p.918-933, 2003. 
SANTANA, E. Nem tudo são rosas. Revista Tecnologística, v.2, n.23, p.18-24, out. 1997.

SCHOENMAKER, S.; CAVICCHIO, L.C. Lírios: os símbolos da pureza. Jardim de Flores, 25 nov. 2002. http://www.jardimdeflores.com.br/floresefolhas/ A21lirios.htm (28 jun. 2004)

SEMBOJA, H.H.H.; MBELWA, R.; BONAVENTURA, C. The cut-flower industry in Tanzânia. Geneva: International Labour Office, Mar. 2000. (Working paper, 152) http://www.ilo.org/public/english/dialogue/sector/papers/tanzflow/index.htm (17 Apr. 2004)

SIMÕES, F.C.; PAIVA, P.D.O.; NERI, G.J.O.; PAIVA, R. Noções básicas de jardinagem. http://www.editora.ufla.br/Boletim/pdfextensao/bol_61.pdf (29 abr. 2004)

SMORIGO, J.N. Análise da eficiência dos sistemas de distribuição de flores e plantas ornamentais no Estado de São Paulo. Piracicaba, 2000. 132p. Dissertação (Mestrado) - Escola Superior de Agricultura “Luiz de Queiroz”, Universidade de São Paulo.

SNELS, J. Potplanten korter onderweg. Informatie, v.27, n.8, p.48-53, Dec. 2003. http://www.informatie.nl/artikelen/2003/12/potplantenKorterOnderweg.html May 2004)

SOUZA, R.M. Oficializada hoje Câmara Setorial Federal de Flores e Plantas. O Estado de São Paulo, São Paulo, 19 jun. 2003. http://www.estadao.com.pt/ economia/noticias/2003/ jun/19/113.htm (18 jan. 2004)

STUANI, R. Investidores internacionais iniciam megaprojeto de US\$ 345 milhões em São Paulo. Agência Estado. http://www.ferrobam.com.br/ notset259.htm (25 set. 2000)

THOEN, R.; JAFFEE, S.; DOLAN, C.; BA, F. Equatorial rose: the keyan-european cut flower supply chain. In: KOPIKI, R. (Ed.). Supply chain development in emerging markets: case students of supportive public policy. Washington: World Bank, 2001. http://www1.wordbank.org/wbiep/trade/c/papers/roses2kenya supplychain.pdf (14 Feb. 2003) 
VARA, J. A abordagem sistêmica na gestão da qualidade. Revista Qualidade, n.3, out. 2001. http://www.icgzn.pt/pdf/5-2002/pagina\%2036-37.pdf(13 jul. 2002)

VIDAL, C.J.; GOETSCHALCKX, M. Strategic production-distribution models: a critical review with enphasis on global supply chain models. European Journal of Operational Research, v.98, n.1, p.1-18, 1997.

VIRACOPOS será o maior do país, diz a Infraero. Gazeta Mercantil, São Paulo, 24 jul. 2003. http://www.marinhamercante.com.br/clippingnacional.asp (23 nov. 2003)

VORST, J.G.A.J. van der; DIJK, S.J.; BEULENS, A.J.M. Supply chain design in the food industry. The International Journal of Logistics Management, v.12, n.2, p.72-85, 2001.

WALT, V. Mercado das flores. National Geographic Brasil, v.2, n.4, p.96-113, abr. 2001.

WELBY, E.; McGREGOR, B. Agriculture export transportation handbook. Washington: USDA, $2004 . \quad 148 \mathrm{p}$. http://www.ams.usda.gov/tmd_export/AgExTransHand04.pdf (26 May 2004)

WOOD, T. Jr.; ZUFFO, P.K. Supply chain management. Revista de Administração de Empresas, v.38, n.3, p.55-63, 1998.

WORLD BANK. Global economic prospects and the developing countries. Washington, 2002. 271p. http:/www.worldbank.org/prospects/gep2002/ gep2002complete.pdf (02 June 2004)

WORLD BANK. Global economic prospects and the developing countries. Washington, 2004. 334p. http://www.worldbank.org/prospects/gep2004_full.pdf (02 June 2004) 
APÊNDICES 


\section{APÊNDICE 1 - Principais práticas operacionais relacionadas à exportação de produtos brasileiros}

No Brasil, para movimentar a carga aérea internacional existem os seguintes órgãos e entidades: Infraero (Empresa Brasileira de Infra-Estrutura Aeroportuária), Receita Federal, Ministério da Saúde, Ministério da Agricultura, Polícia Federal, Polícia

Militar, importadores, exportadores, empresas aéreas, agentes e despachantes aduaneiros.

A exportação de mercadorias pode ser realizada de maneira direta, ou seja, do produtor ou indústria para o importador no exterior, ou indireta, na qual é inserido o agente intermediário, representado por exportador, consórcio, trading company ou cooperativa.

As flores de corte são mais comumente comercializadas através de exportadores ou cooperativas e, por agregar volumes maiores de vários produtores, conseguem obter tarifas menores junto a companhias aéreas e despachantes. De acordo com Keedi \& Mendonça (2000), para esses produtos aplica-se, em geral, a tarifa quantitativa estabelecida pela IATA (International Air Transport Association) para área 1 (Américas), área 2 (Europa, África e parte oeste da Ásia) e área 3 (Ásia, exceto parte oeste, e Oceania). É dividida nas seguintes faixas: até $45 \mathrm{~kg}$; de 45 a $100 \mathrm{~kg}$, 100 a 300 $\mathrm{kg}, 300$ a $500 \mathrm{~kg}$ e acima de $500 \mathrm{~kg}$. Nesse caso, quanto maior for o peso da carga menor será a tarifa unitária. Por exemplo, ao considerar o custo do frete aéreo da Nova Zelândia para o Brasil $^{6}$, para mercadorias de até $45 \mathrm{~kg}$, cobra-se US\$ 16.54/kg; de 45 a $100 \mathrm{~kg}$, US\$ 12.35/kg; de 100 a 300 kg, US\$12.07/kg; de 300 a 500 kg, US\$10.50/kg; acima de $500 \mathrm{~kg}$, US\$ 9.65/kg. Apesar do frete ser cobrado por peso, a relação entre este e o volume da carga é levada em conta para o cálculo do frete, obtendo-se o peso cubado, conforme mostra a eq. (25).

$$
\text { peso cubado }=\frac{C \times L \times A}{6000}
$$

\footnotetext{
${ }^{6}$ Disponível em http://www.airnz.co.nz
} 
onde:

$C=$ comprimento;

$L=$ largura;

$A=$ altura

Conforme Ferreira (2003), se for contratado um agente de carga para fazer a reserva do espaço aéreo, pode haver redução no custo do frete. Isso ocorre por haver a possibilidade de ser realizada negociação com a companhia aérea a partir do agrupamento (ou consolidação) de cargas num único contrato de transporte (Master Airway Bill).

Para que se exportem os produtos no Brasil, de acordo com Castro (2003, p.48), é necessário inicialmente que seja realizado credenciamento do exportador na Receita Federal para operar o Sistema Integrado de Comércio Exterior (SISCOMEX), que processa e controla de modo informatizado as operações de exportação. A seguir é formado o preço de exportação, ou seja, devem ser considerados todos os impostos incidentes no preço do produto no mercado interno e despesas com embalagem para exportação, paletização, despachante aduaneiro, corretagem, propaganda no exterior e outras despesas operacionais, para que sejam feitos o contrato de venda e a produção do produto para ser exportado. Pode ser realizada a contratação de câmbio e de frete ou de seguro internacional, antes da emissão no SISCOMEX da nota fiscal da mercadoria, do registro de exportação (ou do registro de exportação simplificado, para valores abaixo de US\$ 10 mil), da declaração de despacho da exportação (ou declaração simplificada de exportação) para que o produto seja embarcado. No caso das flores de corte, há isenção de impostos para que sejam exportadas.

O despacho aduaneiro pode ser feito pelo exportador ou pelo próprio despachante aduaneiro e é iniciado com a emissão do registro de exportação ou do registro de exportação simplificado. Esse procedimento visa obter a autorização legal da exportação do produto no momento do embarque, executada pelo fiscal aduaneiro da Receita Federal, por meio da análise do extrato da declaração de despacho aduaneiro, da nota fiscal, do conhecimento de embarque (Airway Bill, sob a responsabilidade da companhia 
aérea, com a data de embarque e a origem legal da mercadoria), do romaneio de embarque (packing list, que é feito pelo exportador e contém a relação de volumes de todas as mercadorias exportadas) e outros documentos específicos em função do produto ou das exigências do país de destino. No caso das flores, há a inclusão do certificado fitossanitário, emitido por órgãos do Ministério da Agricultura.

A fatura comercial (commercial invoice) é essencial para que o importador libere a mercadoria no seu país, pois contém dados da mercadoria (descrição, valor na moeda estrangeira, peso), das condições de venda (International Commercial Terms Incoterms, ou seja, contém as definições mais usuais utilizadas no comércio internacional e das formas de pagamento. Além dessa fatura, redigida comumente em inglês ou espanhol, há a emissão da nota fiscal, em português e em moeda brasileira (real), conforme documentado por Castro (2003).

Em relação às flores de corte, a condição de venda mais comum é FOB (Free on Board), no qual as despesas do exportador estendem-se só até o local de embarque da mercadoria, e a exportação feita em consignação, a partir da qual é possível que o exportador informe preços mínimos dos produtos, realizando a correção cambial dos valores obtidos pela venda no exterior após 30 dias da efetivação da remessa. O contrato de câmbio é realizado entre o exportador e um banco, autorizado pelo Banco Central, para converter o valor recebido no Brasil pela venda da mercadoria em moeda nacional.

A Infraero constitui a zona primária do território aduaneiro e administra os 65 aeroportos no Brasil, que concentram 97\% do movimento do transporte aéreo regular do Brasil, com 82 estações de apoio à navegação aérea e 32 terminais de logística de carga. De acordo com Ferreira (2003), para auxiliar na movimentação, armazenagem e despacho aduaneiro de mercadorias, há também a zona secundária ou porto seco, localizada em área distinta da zona primária.

Conforme Problemas e Soluções (2000), a Infraero obtém os maiores ganhos com os aeroportos de Congonhas, Guarulhos e Viracopos. Em 2002 essa empresa fez investimentos da ordem de R\$900 milhões em projetos e serviços no setor, sendo que, conforme Infraero (2003), em 2003 foram adquiridos e instalados oito scanners importados para inspeção de cargas nos Terminais de Carga de Guarulhos, Campinas, 
Manaus, Galeão, Porto Alegre e Curitiba, a pedido da Receita Federal. Inaugurado no final de 2002, o terminal de carga de Viracopos também poderá ser ampliado e modernizado, pois o nível de serviço informatizado é ainda pequeno em relação ao grande volume importado. As remessas expressas desse aeroporto correspondem a $90 \%$ do total desembarcado no Brasil.

O aeroporto de Viracopos ${ }^{7}$ possui um Terminal de Exportação, com área total de $8.000 \mathrm{~m}^{2}$, e para importação com área de $36.500 \mathrm{~m}^{2}$. Há companhias aéreas cargueiras com vôos regulares, como é o caso de Era Equatoriana, Ibéria, Fast Air, Varig S/A, Luflhansa, Fedex Express, Lan Chile, Swissair, ABSA, British, Airways, Aerolíneas Argentinas, Aemmexpress, Lloyd, UPS, American International, Polar Air Cargo, ATI AS AIR.

Conforme Keedi \& Mendonça (2000), as aeronaves podem ser de 3 tipos: Full Pax, All Cargo ou Full Cargo e Combi. Suas principais características estão sumarizadas na Tabela 9. De acordo com Panorama Setorial da Gazeta Mercantil, citado por Franco et al. (2002), o custo de aquisição de um Boeing 737-300, em 1997, era de US\$ 32 milhões no Brasil e de US\$ 27 milhões em contratos com companhias americanas.

\footnotetext{
${ }^{7}$ Informações disponíveis em http://www.infraero.gov.br
} 
Tabela 19. Principais características de aeronaves utilizadas em aeroportos brasileiros

\begin{tabular}{|c|c|c|c|c|}
\hline $\begin{array}{l}\text { Tipo de } \\
\text { aeronave }\end{array}$ & Características & modelo & Peso $(\mathrm{t})$ & $\begin{array}{l}\text { Volume } \\
\left(\mathrm{m}^{3}\right)\end{array}$ \\
\hline \multirow{7}{*}{$\begin{array}{l}\text { All Cargo } \\
\text { (ou Full } \\
\text { Cargo) }\end{array}$} & \multirow{7}{*}{$\begin{array}{l}\text { Cargueiro, com } \\
\text { transporte de carga nos } \\
\text { andares superior e } \\
\text { inferior }\end{array}$} & Antonov 124/100 & 115 & 770 \\
\hline & & Boeing 747 & 100 & 600 \\
\hline & & MD 11 & 60 & 400 \\
\hline & & DC 8 & 45 & 270 \\
\hline & & Boeing 707 & 36 & 220 \\
\hline & & Boeing 777 & 28 & 160 \\
\hline & & Boeing 737 & 15 & 90 \\
\hline \multirow[t]{2}{*}{ Combi } & \multirow{2}{*}{$\begin{array}{l}\text { Transporte cargas e de } \\
\text { passageiros nos andares } \\
\text { superior e inferior }\end{array}$} & Boeing 747 & 30 & 180 \\
\hline & & MD 11 & 25 & 250 \\
\hline \multirow[t]{6}{*}{ Full Pax } & \multirow{6}{*}{$\begin{array}{l}\text { Transporte de } \\
\text { passageiros no andar } \\
\text { superior e de bagagem } \\
\text { no inferior }\end{array}$} & Boeing 747 & 14 & 90 \\
\hline & & DC 10 & 14 & 90 \\
\hline & & Airbus A310 & 11 & 70 \\
\hline & & Boeing 767 & 9 & 60 \\
\hline & & Boeing 757 & 5 & 30 \\
\hline & & Fokker 100 & 1,2 & 7 \\
\hline
\end{tabular}

Fonte: adaptado de Keedi \& Mendonça (2003, p.156-157)

No aeroporto de Guarulhos, a área dos armazéns alfandegários do Terminal de Cargas (TECA-Guarulhos) para exportação é de $22.887 \mathrm{~m}^{2}$ e para importação é de $41.465 \mathrm{~m}^{2}$. Essa área é a maior da América do Sul, onde estão inseridos serviços de atracação, unitização, despaletização, movimentação e armazenagem para a carga com regime aduaneiro de importação e exportação, com certificado ISO 9001 para uso de equipamentos. Há um total de $80.612 \mathrm{~m}^{2}$ de câmaras frigoríficas e com 5 módulos de $2^{\circ}$ $\mathrm{C}$ a $8^{\circ} \mathrm{C}, 3$ módulos de $2^{\circ} \mathrm{C}$ a $15^{\circ} \mathrm{C}$ e 1 módulo $2^{\circ} \mathrm{C}$ a $-20^{\circ} \mathrm{C}$. Há 118 terminais com o sistema de controle do fluxo e armazenagem interligado ao sistema MANTRA da Receita Federal, 37 docas para recebimento e envio simultâneos com 11 plataformas hidráulicas, 85 empilhadeiras com capacidade limite de até 10 toneladas, 35 balanças aferidas para até 15 toneladas e equipamentos de raio X para inspeção de carga e serviço de atendimento ao cliente de carga Aérea Internacional.

De acordo com Carlos Wilson Campos, presidente da Empresa Brasileira de Infra-Estrutura Aeroportuária (Infraero), citado por Viracopos (2003), o aeroporto de 
Viracopos possui um projeto de ampliação até 2007 , com investimentos de cerca de R\$ 260 milhões. Apesar do aeroporto de Guarulhos possuir um significativo volume de carga destinado às exportações quando comparado aos demais aeroportos do Estado de São Paulo, não há mais área disponível para sua expansão. Desta forma, Viracopos torna-se uma alternativa bastante atrativa tanto para transporte de passageiros como de carga. 


\section{APÊNDICE 2 - Descrição das flores estudadas: lírio e gérbera}

As flores de corte tratadas neste trabalho - gérbera e lírio - possuem características bem distintas. Dada a sua importância econômica para o Brasil, ambas foram incluídas na publicação sobre padrão de qualidade IBRAFLOR, do Instituto Brasileiro de Floricultura, lançado em junho de 2000. Nesse levantamento foram considerados 21 produtos, que representavam $80 \%$ da comercialização brasileira nessa época, de acordo com Instituto Brasileiro de Floricultura (IBRAFLOR, 2000). As flores de corte inseridas foram: rosas, crisântemos, gipsófilas, cravos, gérberas, solidago, lírios e helicônias. Segundo Florabrasilis (2002), dentre as flores de corte cultivadas no Brasil, gérbera e lírio correspondem a 5,83\% e 2,87\%, respectivamente, da área total cultivada. Além do Estado de São Paulo, há também produções de lírio no Paraná e Rio Grande do Sul, e de gérbera no Ceará, Pernambuco, Espírito Santo, Paraná e Rio Grande do Sul.

No caso de lírio, Amaryllis e tulipa, a sua multiplicação ocorre por meio de bulbos. A Figura 43 mostra, como exemplo, a evolução do crescimento de bulbos de Amaryllis. A partir deles são geradas as folhas e as flores. De acordo com Simões et al. (2004), na parte lateral do bulbo-mãe são formados os bulbilhos. Com o seu replantio podem ser utilizados para o cultivo normal de flores.

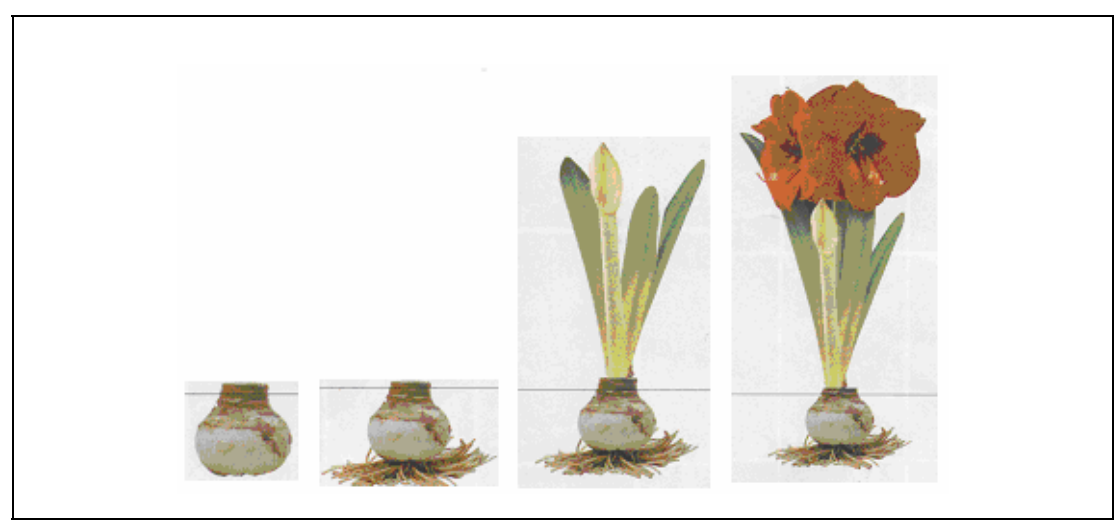

Figura 43 - Ciclo de crescimento de bulbos de flores de Amaryllis

Fonte: Boersen (2001) 
O lírio pertence à família Liliaceae e suas espécies são originárias da Ásia e Europa. De acordo com Schoenmaker e Cavicchio (2002), foram realizados muitos cruzamentos dessas espécies, tendo como conseqüência criação de grande quantidade de variedades. Há grupos de lírios orientais e asiáticos, que se destinam principalmente à produção de corte e de vaso. Distinguem-se pelo tamanho e cor de suas flores e pela intensidade de perfume que essas flores exalam. De acordo com informações do setor, os lírios de origem asiática são mais fáceis de cultivar e possuem maior disponibilidade no mercado. A Figura 44 ilustra as variedades de lírio oriental e asiático.

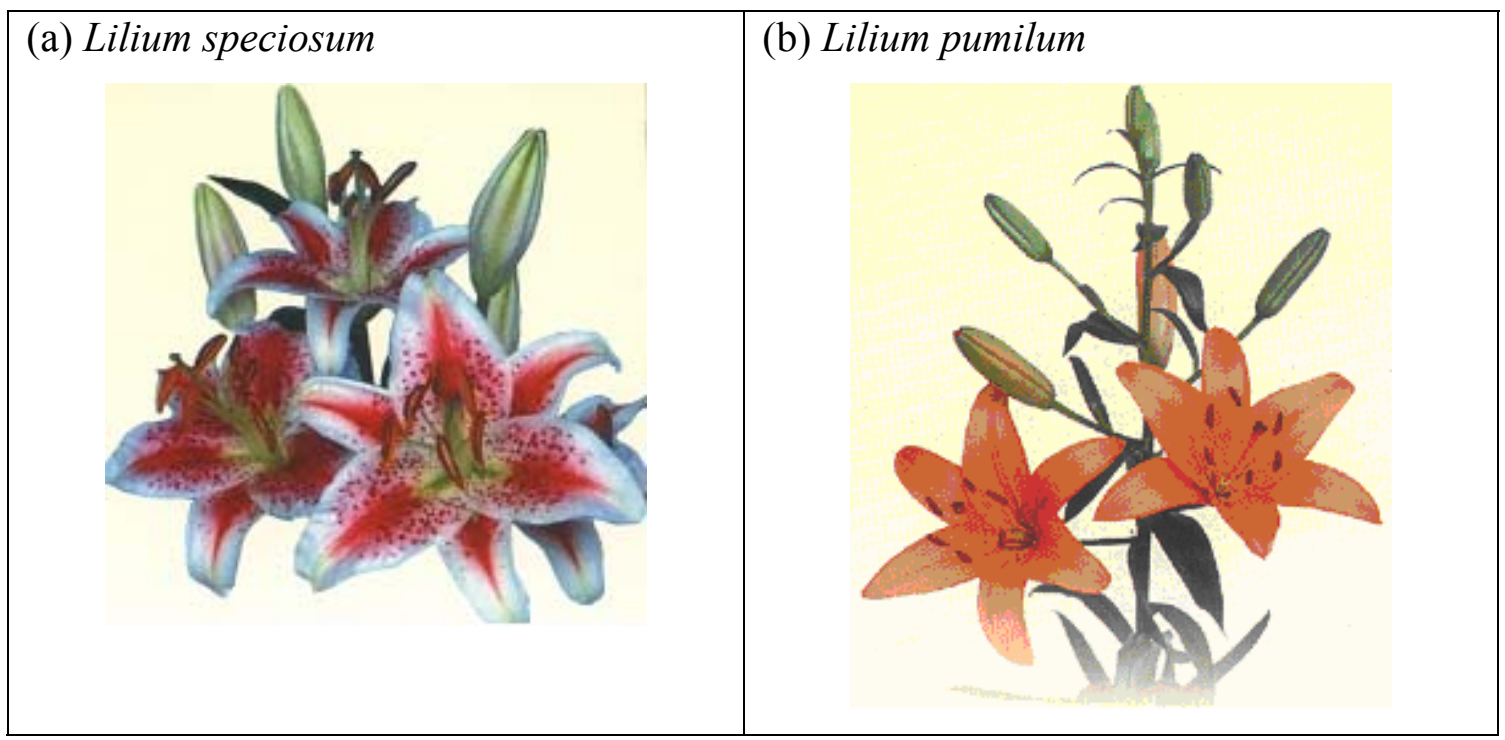

Figura 44 - Variedades de lírio oriental (a) e asiático (b)

Fonte: Instituto Brasileiro de Floricultura (2000)

Conforme Caixeta-Filho, Swaay-Neto e Wagemaker (2002), como não há produção em larga escala desses bulbos no Brasil, a maioria é importada da Holanda. O ciclo de produção do lírio, a partir da compra dos bulbos, pode variar de 6 a 16 semanas, em função da variedade e bulbo utilizados e da época de plantio.

As gérberas são provenientes da África do Sul e pertencem à família Asteraceae. Conforme Blanco (2001), sua propagação é distinta do lírio, pois é realizada por meio de sementes ou divisão de touceiras. Como há grande amplitude de cores, com mais de 20 
tonalidades, e florescem praticamente o ano todo, são muito requisitadas para arranjos florais. Algumas delas são apresentadas na Figura 45.

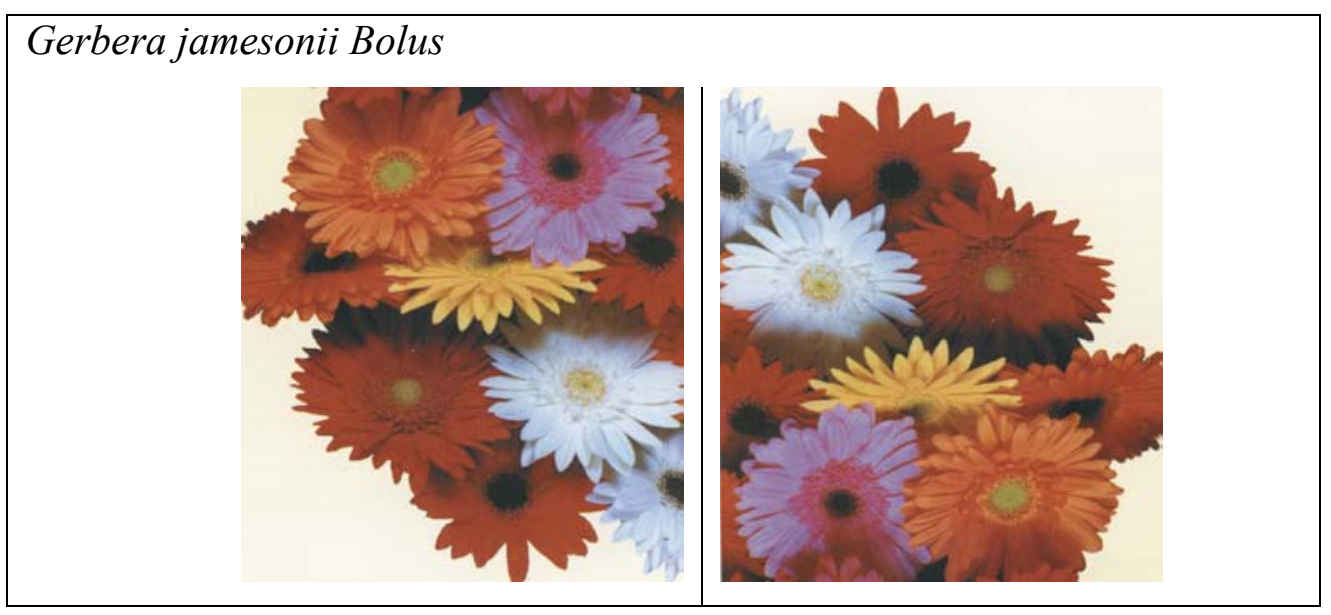

Figura 45 - Variedades de gérbera

Fonte: Instituto Brasileiro de Floricultura (2000)

De acordo com informações do setor, em 2002 havia 68 variedades distintas de gérbera sendo cultivadas no Brasil, com preferência maior do consumidor por gérberas vermelhas, amarelas e brancas e menor pelas cores rosa, salmão e chá. Devido à seleção de variedades, seu número se reduziu para 45 em 2003 e a demanda concentrou-se em flores lilás. No verão as flores têm maior produtividade, implicando menor tempo de produção. No inverno a sua formação é melhor, porém são seu ciclo é mais longo. Conforme Kessler Junior (1999), o período de produção pode variar de 14 a 18 semanas, a partir do plantio das sementes. 